\title{
Funkcionális kompozit rendszerek előállítása, jellemzése és alkalmazási lehetőségeik
}

\section{Imre-Deák Ágota}

okleveles vegyész

Témavezető

Dr. Janovák László

egyetemi adjunktus

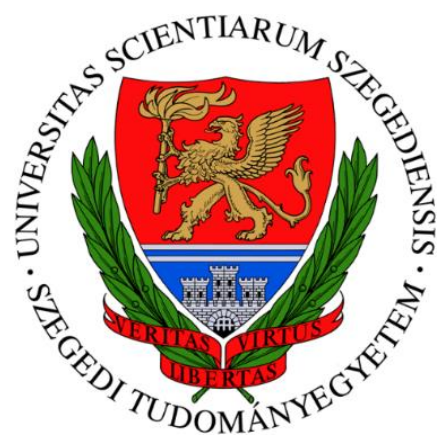

Kémia Doktori Iskola

Szegedi Tudományegyetem

Természettudományi és Informatikai kar

Fizikai Kémiai és Anyagtudományi Tanszék

Szeged

2019 


\section{Tartalomjegyzék}

Az értekezésben használt rövidítések jegyzéke ............................................................... 4

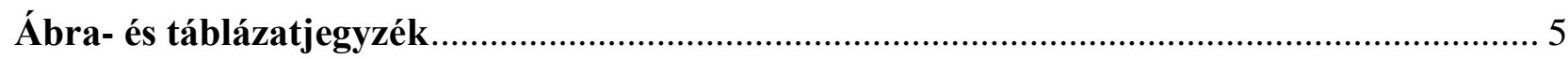

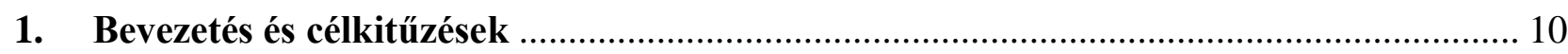

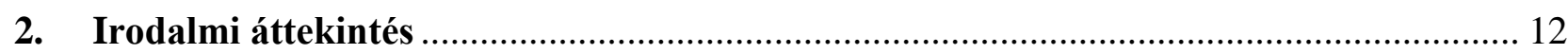

2.1 Kompozitok és kompozit alapú felületek.............................................................. 12

2.2 Lamellás szerkezettel rendelkező kompozit töltőanyagok ..................................... 13

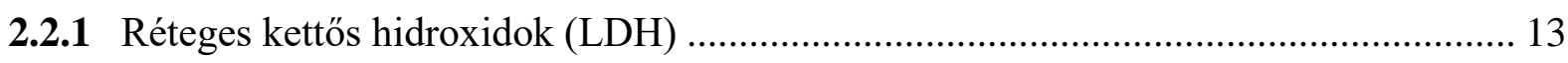

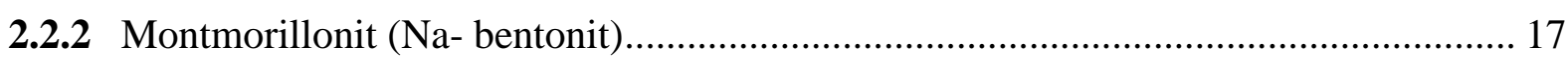

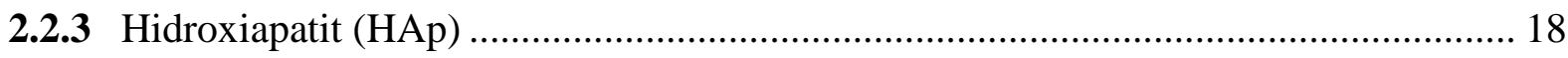

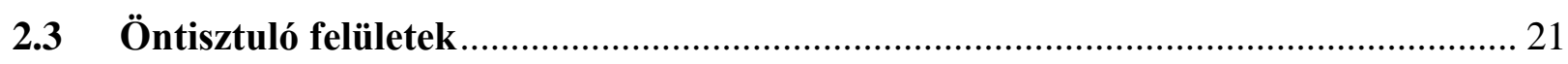

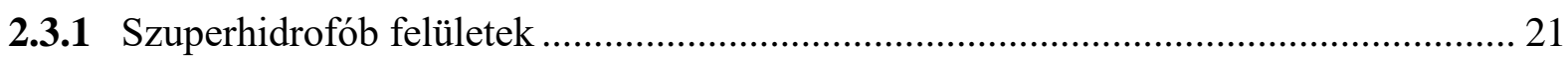

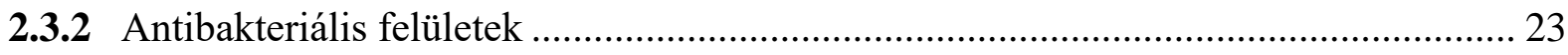

3. Kísérleti körülmények és vizsgálati módszerek ........................................................ 25

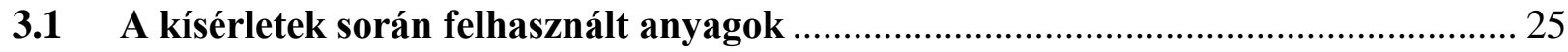

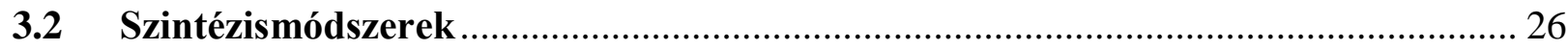

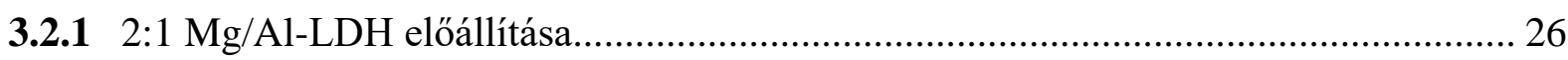

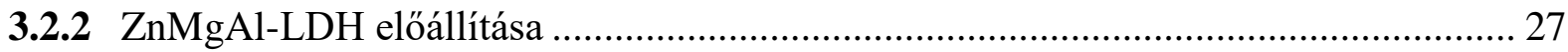

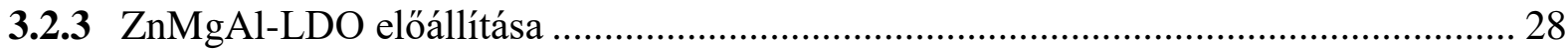

3.2.4 Felületi ezüst nanorészecskéket tartalmazó montmorillonit szintézise ....................... 28

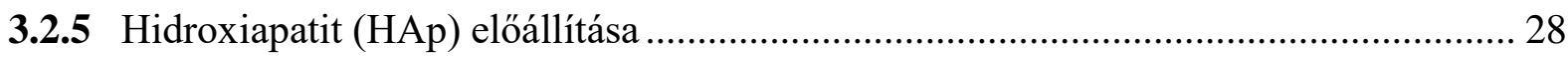

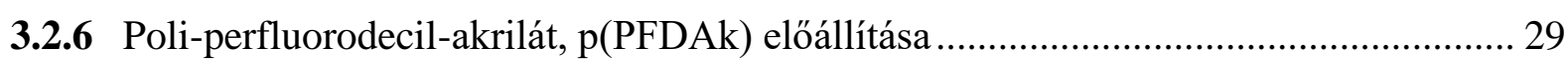

3.2.7 Kinurénsav/ LDH interkalációs nanokompozit előállítása....................................... 29

3.2.8 LDH/ $\mathrm{Ag}^{0}$-montmorillonit heterokoagulációs kompozit előállítása........................... 29

3.2.9 LDO/p(PFDAk) fluoropolimer rétegek kialakítása ................................................ 30

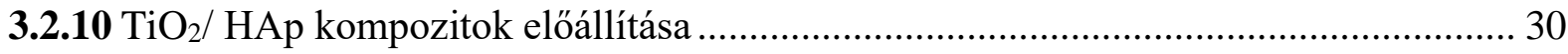

3.2.11 $\mathrm{TiO}_{2} / \mathrm{HAp} / \mathrm{p}(\mathrm{EA}-\mathrm{co}-\mathrm{MMA})$ polimer kompozitok kialakítása .................................. 31

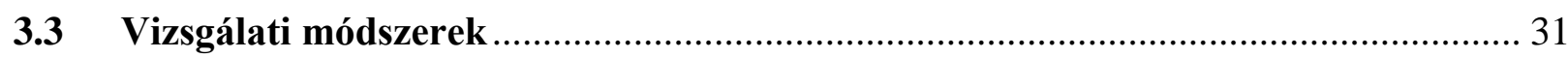

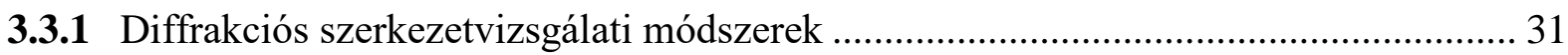

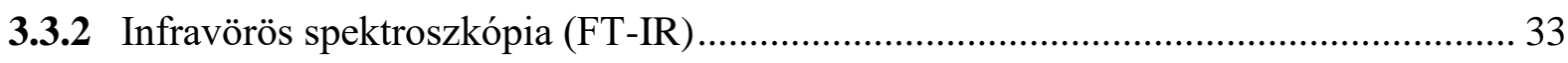

3.3.3 A minták fajlagos felületi töltésének meghatározása ............................................... 33

3.3.4 A fajlagos (BET) felület meghatározása ............................................................ 34

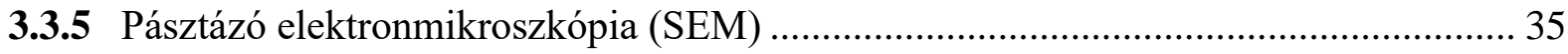

3.3.6 Energiadiszperzív röntgenspektroszkópia (EDS) …............................................ 35 


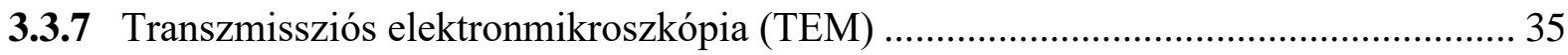

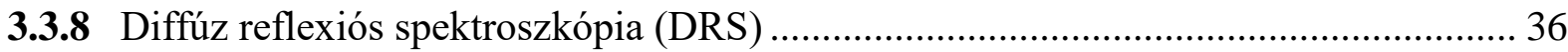

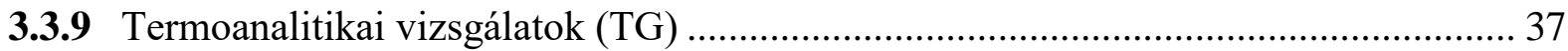

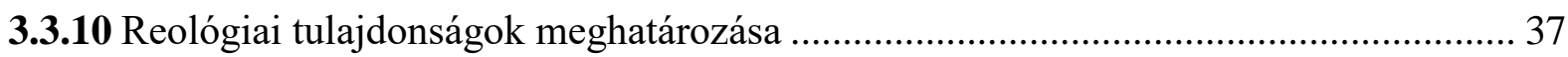

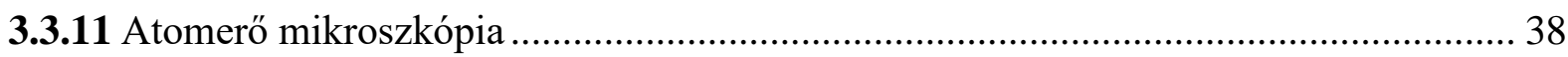

3.3.12 A felületi érdesség profilometriás meghatározása.................................................. 38

3.3.13 Kompozit rétegek nedvesedési tulajdonságainak meghatározása ................................ 39

3.3.14 Fotokatalitikus hatékonyság meghatározása .......................................................... 41

3.3.15 A fotokatalizátor kompozit rétegek felületén képződő szabadgyök meghatározása.... 42

3.3.16 Baktériumok adhéziójának vizsgálata kompozit rétegek felszínén............................. 43

3.3.17 Fotokatalizátor tartalmú kompozit rétegek antibakteriális tulajdonságának vizsgálata fluoreszcens mikroszkóp alkalmazásával......................................................................... 45

3.3.18 LDH oldása szintetikus gyomornedv (SGF) közegben ........................................... 45

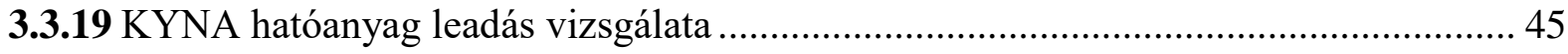

3.3.20 LDH/ $\mathrm{Ag}^{0}$-montmorillonit két komponensű rendszer $\mathrm{pH}$-függésének vizsgálata........ 46

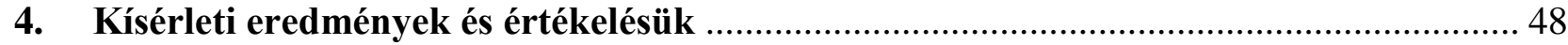

4.1 Lamellás szerkezetü LDH és kinurénsav/ LDH kompozitok jellemzése ….............. 49

4.1.1 Lamellás szerkezetű LDH szerkezeti jellemzése ..................................................... 49

4.1.2 Rétegközi kinurénsav (KYNA) hatóanyagot tartalmazó LDH alapú kompozit előállítása és szerkezetvizsgálata.

4.1.3 A KYNA hatóanyag kioldódásának meghatározása az LDH alapú nanohibrid rendszerböl gasztrointesztinális körülmények között ...................................................... 54

4.2 A gömbi morfológiájú LDH és $\mathbf{L D H} / \mathbf{A g}^{\mathbf{0}}$-montmorillonit kompozit jellemzése...... 59

4.2.1 A gömbi morfológiájú LDH szerkezeti jellemzése ................................................. 59

4.2.2 Gömbi morfológiájú $\mathrm{LDH} \mathrm{Ag}^{0}$-montmorillonittal alkotott kompozit jellemzése........ 63

4.2.3 Az LDH/ $\mathrm{Ag}^{0}$-montmorillonit kompozitok pH-függő antibakteriális tulajdonsága ..... 66

4.3 A gömbi morfológiájú LDO és LDO/ p(PFDAk) polimer kompozitok jellemzése ... 71

4.3.1 A gömbi morfológiájú LDO szerkezeti jellemzése ................................................. 71

4.3.2 $\mathrm{Az} \mathrm{LDO/p(PFDAk)} \mathrm{polimer} \mathrm{kompozit} \mathrm{filmek} \mathrm{tulajdonságai} \mathrm{..................................} 73$

4.3.3 Baktériumok adhéziójának vizsgálata kompozit rétegek felszínén........................... 82

4.4 HAp/ $\mathrm{TiO}_{2} /$ p(EA-co-MMA kompozitok jellemzése .............................................. 87

4.4.1 Hidroxiapatit (HAp) lamellák szerkezeti jellemzői................................................ 87

4.4.2 $\mathrm{TiO}_{2} / \mathrm{HAp}$ kompozitok szerkezeti tulajdonságai .................................................... 88

4.4.3 A HAp lamellák szinergikus hatása a $\mathrm{TiO}_{2} / \mathrm{p}(\mathrm{EA}-\mathrm{co}-\mathrm{MMA})$ vékonyrétegek

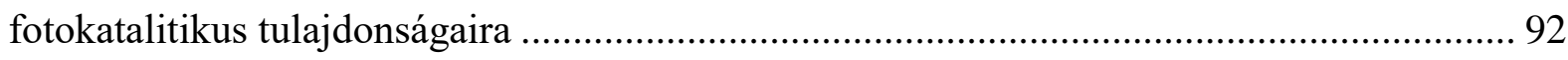




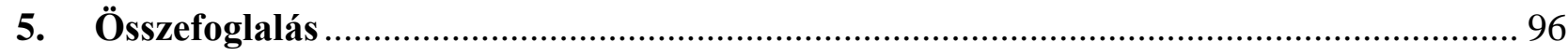

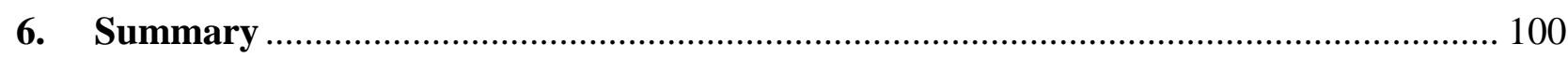

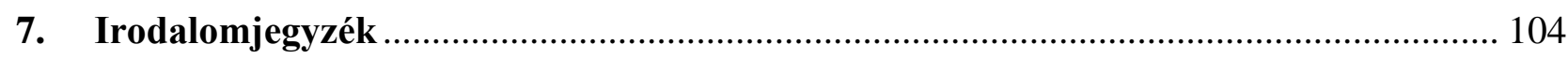

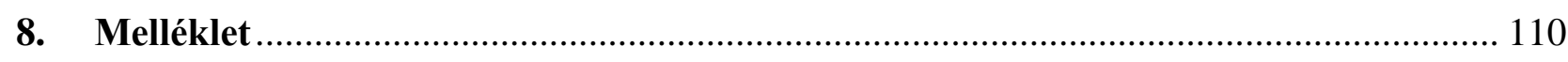

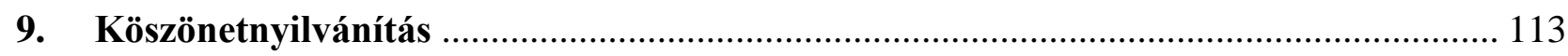

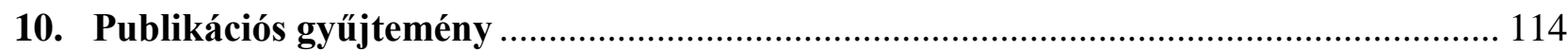




\section{Az értekezésben használt rövidítések jegyzéke}

AFM - Atomic force microscope - atomerő mikroszkópia

CFU - Colony forming unit - telepképző egység

DRS - Diffuse reflectance spectroscopy - diffúz reflexiós spektroszkópia

EDS - Energy dispersive spectroscopy - energiadiszperzív röntgenspektroszkópia

EtOH - Ethanol - Etanol

FT-IR - Fourier-transform infrared spectroscopy - Fourier-transzformációs infravörös spektroszkópia

GC - Gas chromatography - gázkromatográfia

HAp - Hydroxyapatite - Hidroxiapatit

$\mathrm{HDPCl}$ - Hexadecyl pyridinium chloride - Hexadecil-piridínium-klorid

KYNA - Kynurenic acid -Kinurénsav

LDH - Layered double hydroxide - Réteges kettős hidroxid

LDO - Layered double oxide - Réteges kettős oxid

NaDS - Sodium dodecyl sulfate - Nátrium-dodecil-szulfát

NPs - Nanoparticles - nanorészecskék

p(EA-co-MMA) - poly(ethyl acrylate-co-methyl methacrylate) - poli(etil-akrilát-ko-metilmetakrilát) - Plextol

p(PFDAk) - poly(perfluorodecyl acrylate) - poli(perfluorodecil-akrilát)

PBS - Phosphate-buffered saline - $\mathrm{NaCl}$ tartalmú foszfát-puffer $(\mathrm{pH}=7,4$ és $0,15 \mathrm{M} \mathrm{NaCl})$

ROS - Reactive Oxygen Species - reaktív oxigén tartalmú gyökök

SAXS - Small-angle X-ray scattering - kisszögü röntgenszórás

SEM - Scanning electron microscopy - pásztázó elektronmikroszkópia

SGF - Simulated gastric fluid - szintetikus gyomornedv

TEM - Transmission electron microscopy - transzmissziós elektronmikroszkópia

TG -Thermogravimetria - termogravimetria

UV-VIS - Ultraviolet-visible - ultraibolya-látható (spektrofotometria)

XRD - X-ray diffraction - röntgendiffrakció 


\section{Ábra- és táblázatjegyzék}

1. ábra. Az LDH-ák szerkezeti felépítésének sematikus ábrázolása.

2. ábra. A ,virág” (a) és „málna” (b) alakú üreges LDH gömbök egy-egy példaként bemutatott SEM felvétele.

3. ábra. A CoFe ${ }^{\mathrm{II}} \mathrm{Fe}^{\mathrm{III}}-\mathrm{LDH}$ gömb-héj szerkezet kialakulásának sematikus ábrája.

4. ábra. A kialakuló gömb alakú MgAl-LDH sematikus ábrája.

5. ábra. A montmorillonit (2:1 típusú rétegszilikát) szerkezete.

6. ábra. A csontszerkezet hierarchikus felépítésének sematikus ábrája, mikro- és nano-skálán bemutatva.

7. ábra. Érdes felületek Wenzel (a) és Cassie-Baxter (b) féle nedvesedési állapotait bemutató sematikus ábrái.

8. ábra. $\mathrm{A} \mathrm{TiO}_{2}$ fotokatalizátor gerjesztésének sematikus ábrája és a lejátszódó kémiai folyamatok.

9. ábra. A Mütek PCD 02-es részecske töltés detektor készülék fotója (a) és sematikus (hosszmetszeti) ábrája (b).

10. ábra. A diffúz-reflexiós mérések során használt integráló gömb fotója (a) és sematikus ábrája (b).

11. ábra. A referencia Nanox $\mathrm{ZnO}$ diffúz-reflexiós spektruma (330-730 nm hullámhossz tartományon) (a) és a diffúz-reflexiós mérésből, Kubelka-Munk módszer alapján számított gerjesztési küszöbenergia ( $\left.E_{g}\right)$ érték meghatározása (b).

12. ábra. Az Anton Paar Physica MCR 301 típusú reométer (a) és a DG 26.7 típusú mérőfej (b) fotója, valamint a mérőfej sematikus (hosszmetszeti) ábrája (c).

13. ábra. $A$ felületi érdesség kifejezése átlagos érdesség $\left(R_{a}\right)$, ill a négyzetes durvaság $\left(R_{q}\right)$ érdességi mutatókkal.

14. ábra. A peremszög mérések során alkalmazott Krüss, Easy Drop müszer fotója.

15. ábra. A cseppfelépítési és cseppelvételi technika (kontaktszög $\left(\Theta_{\mathrm{w}}\right)(\mathbf{a})$, haladó $\left(\Theta_{\mathrm{Adv}}\right)(\mathbf{b})$ és hátráló $\left(\Theta_{\text {Rec }}\right)(\mathbf{c})$ peremszögek) sematikus ábrája.

16. ábra. A mérések során alkalmazott kísérleti elrendezés sematikus ábrája (a) és az alkalmazott fényforrás ( $\mathrm{S} 1$ fénycső, $5 \mathrm{~cm}$ távolságon mért teljesítménye: $6,38 \mathrm{~mW} / \mathrm{cm}^{2}$ ) emissziós spektruma (b).

17. ábra. Az etanol tesztmolekula fotodegradációja során alkalmazott kísérleti elrendezés (a) és a LED típusú fényforrás emissziós spektruma (b), $5 \mathrm{~cm}$ távolságon mért teljesítménye: $24,28 \mathrm{~mW} / \mathrm{cm}^{2}$.

18. ábra. A luminol molekula reakciója hidrogén-peroxiddal.

19. ábra. A luminometriás mérések során alkalmazott kísérleti elrendezés.

20. ábra. A kioldódási tesztek során használt vertikális diffúziós cella sematikus ábrája (a) és fotója (b). 
21. ábra. Az előállított komponensek és kialakított kompozitok összefoglaló sematikus ábrája, a lehetséges alkalmazási területek megjelölésével.

22. ábra. A lamellás szerkezetü $2: 1 \mathrm{Mg} / \mathrm{Al}-\mathrm{LDH}$ porminta röntgendiffraktogramja és egy reprezentatív SEM felvétele.

23. ábra. A 2:1 Mg/Al-LDH minta nitrogén adszorpciós izotermája (a) és t-Plot (b) ábrázolása.

24. ábra. A $10 \mathrm{~mL} 0,1 \mathrm{~m} / \mathrm{m} \%$-os $2: 1 \mathrm{Mg} / \mathrm{Al}-\mathrm{LDH}$ szuszpenzió áramlási potenciál értéke a hozzáadott $0,1 \mathrm{~m} / \mathrm{m} \%$-os vizes tenzidoldat térfogatának függvényében.

25. ábra. Az LDH lamellák által elektrosztatikusan megkötött KYNA mennyiségének alakulása a KYNA/ LDH tömegarányának növekedésével (a). Az interkalált KYNA mennyiségének meghatározása fluoreszcenciásan (b) $\left(\lambda_{\mathrm{ex}}=350 \mathrm{~nm} ; \lambda_{\mathrm{em}}=355-550 \mathrm{~nm}\right)$.

26. ábra. A kiindulási LDH és KYNA/ LDH interkalációs kompozit porminták röntgendiffraktogramjai.

27. ábra. A kiindulási LDH, KYNA és KYNA/ LDH kompozit FT-IR spektrumai.

28. ábra. A kiindulási LDH, KYNA és KYNA/ LDH kompozit TG (\%) görbéi. (fütési sebesség: $5^{\circ} \mathrm{C} /$ perc).

29. ábra. A gravimetriásan (a) és röntgendiffrakciós (b) mérésekkel nyomon követett LDH oldódása szintetikus gyomornedv (SGF) oldatban, $\mathrm{pH}=1,5$ értéken.

30. ábra. A KYNA hatóanyag százalékos kioldódási profiljai $\left(37^{\circ} \mathrm{C}\right.$-on) különböző pH értékeken (a) és az abszolút kiolódást mutató kinetikai görbék az illesztett elsőrendü függvényekkel (b).

31. ábra. Az LDH rétegek közzé interkalált KYNA hatóanyag és a gyomorba kerülő nanokompozit hatóanyag felszabadulásának sematikus ábrája.

32. ábra. $\mathrm{A}$ különböző $\mathrm{pH}$ értékeken (rendre $\mathrm{pH}=3 ; 5 ; 8 ; 10$ és 12) előállított ZnMgAl-LDH porminták röntgendiffraktogramjai.

33. ábra. $\mathrm{A} \mathrm{pH}=12,01$ (a); 10,03 (b); 8,01 (c); 5,03 (d) és 3,08 (e) értéken elöállított ZnMgAl-LDH minták példaként bemutatott SEM felvételei.

34. ábra. A szintézis (ill. öregítési) idő hatása az elöállított gömbi ZnMgAl-LDH porminták röntgendiffraktogramjaira $(\mathrm{pH}=3)$.

35. ábra. $\mathrm{A} \mathrm{pH}=3$ értéken előállított $\mathrm{ZnMgAl}-\mathrm{LDH}$ minták egy-egy reprezentatív SEM felvételei 24 óra (a), 48 óra (b) és 1 hetes szintézisidő (c) elteltével.

36. ábra. $\mathrm{A} \mathrm{pH}=3$-on elöállított 1 hétig öregített $\mathrm{ZnMgAl-LDH}$ részecskék egy reprezentatív SEM felvétele (a) és a meghatározott méreteloszlási diagram (b).

37. ábra. Az 1 hétig öregített gömbi morfológiájú LDH fajlagos töltés értékének meghatározása pH= 3 értéken áramlási potenciál mérés (a) segítségével és fajlagos töltésmennyiségének alakulása a pH változásával (b).

38. ábra. A kiindulási Na-montmorillonit, ill. $\mathrm{Ag}^{0}$-montmorillonit és a 25:75 (m/m\%) arányú LDH/ $\mathrm{Ag}^{0}$-montm. minták folyásgörbéi $\mathrm{pH}=3$-as (a) és 6-os (b) értékek mellett. 


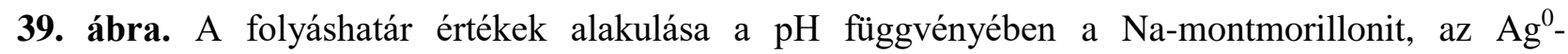
montmorillonit és a 25:75 (m/m\%) arányú LDH/ $\mathrm{Ag}^{0}$-mont. minták esetén.

40. ábra. A $25 / 75 \mathrm{~m} / \mathrm{m} \% \mathrm{LDH} / \mathrm{Ag}^{0}$-montmorillonit szórásgörbéi $\mathrm{pH}=3 ; 4,5$ és 6-os értéken (a) és a minták szórásgörbéinek Porod féle reprezentációja (b).

41. ábra. A kiindulási Na-montm. és $\mathrm{Ag}^{0}$-montm. porminták röntgendiffraktogramjai.

42. ábra. $\mathrm{A}$ Na-montm., $\mathrm{Ag}^{0}$-montm. és $\mathrm{Ag}^{0}$-szol (AgNPs) minták UV-VIS spektruma (a), valamint az $\mathrm{Ag}^{0}$-montm.-ról készített reprezentatív TEM felvétel (b).

43. ábra. A pH-függő szerkezeti tulajdonságokat mutató $(25 / 75 \mathrm{~m} / \mathrm{m} \%) \mathrm{LDH} / \mathrm{Ag}^{0}$-montmorillonit kompozit szol-gél állapotának sematikus ábrája és a rendszerek fotója.

44. ábra. $\mathrm{Az}_{\mathrm{Ag}^{0}}$-montm. kioldódása (\%) $\mathrm{pH}=3$ és 6-os értéken. A beszúrt ábra a kioldódás során alkalmazott Franz-cella sematikus ábráját mutatja.

45. ábra. $A$ különböző koncentrációjú $A g^{0}$-montmorillonit szuszpenziók fotója (a) és szuszpenzók antibakteriális hatását igazoló fotók (b) az Escherichia coli baktérium filmeken jelentkező feltisztulási zónákról.

46. ábra. Az előállított gömbi morfológiájú ZnMgAl-LDH és LDO porminták diffraktogramjai (a), valamint diffúz-reflexiós spektrumai (b, beszúrt ábra) és az LDO és ZnO (Nanox, mint referencia) diffúz-reflexiós méréseiböl, Kubelka-Munk módszer alapján számított gerjesztési küszöbenergia (Eg) értékek (b).

47. ábra. A kiindulási LDH és a kalcinálást követő LDO részecskék SEM felvételei.

48. ábra. $\mathrm{A} p(\mathrm{PFDAk})$ polimer monomeregységének szerkezeti képlete és a fluoropolimer alapú vékonyrétegre cseppenett desztillált víz tesztfolyadék fotója és a mért peremszög érték.

49. ábra. $\mathrm{Az} \mathrm{LDO} / \mathrm{p}(\mathrm{PFDAk})$ kompozit rétegek kilakításának sematikus ábrája (a). A kiindulási p(PFDAk) polimer és az egyre növekvő (20, 40, 60, 80 és 100 m/m\%) LDO tartalmú polimer rétegekről készült reprezentatív SEM felvételek (b).

50. ábra. A kiindulási p(PFDAk) polimer és az egyre növekvő LDO tartalmú polimer rétegek TG(\%) görbéi (fütési sebesség: $5{ }^{\circ} \mathrm{C} /$ perc).

51. ábra. A felületi érdesség $\left(R_{q}\right)$ (a) és vízre kapott peremszög értékek $\left(\Theta_{w}\right)$ (b) alakulása az egyre növekvő LDO tartalmú p(PFDAk) polimer rétegeken.

52. ábra. A desztillált víz tesztfolyadékra kapott haladó $\left(\Theta_{\mathrm{adv}}\right)$ és hátráló $\left(\Theta_{\mathrm{rec}}\right)$ peremszög értékek a sima felületü p(PFDAk) polimer és az érdes felületü, $80 \mathrm{~m} / \mathrm{m} \%$ LDO tartalmú, kompozit réteg esetén.

53. ábra. $\mathrm{Az} \mathrm{LDO} / \mathrm{p}(\mathrm{PFDAk})$ kompozit rétegek látszólagos felületi energia értékeinek $\left(\gamma_{\mathrm{s}}{ }^{\text {tot }}\right)$ változása az érdesség $\left(\mathrm{R}_{\mathrm{q}}\right)$ függvényében.

54. ábra. $\mathrm{Az} \mathrm{LDO} / \mathrm{p}(\mathrm{PFDAk})$ polimer tartalmú kompozit rétegek felszínén képződő reaktív szabadgyökök koncentrációjának $(\mathrm{mM})$ változása a bevilágítási idő függvényében. Alkalmazott fényforrás: $\mathrm{S} 1\left(\lambda_{\max }=365 \mathrm{~nm}\right)$. 
55. ábra. A benzoesav modellmolekula koncentrációjának relatív csökkenése az LDO/ flouropolimer rétegeken, a bevilágítási idő függvényében. Alkalmazott fényforrás: S1 $\left(\lambda_{\max }=365 \mathrm{~nm}\right)$.

56. ábra. A benzoesav modellmolekula bontása során meghatározott sebességi együttható (k’) (a) és az elbontott benzoesav mennyisége (\%) (b) az egyre növekvő LDO tartalmú polimer rétegeken 2 óra bevilágítási idő elteltével.

57. ábra. A szuperhidrofób és fotoreaktív tulajdonságokkal rendelkező réteges kettős oxid (LDO)/ fluoropolimer hibrid réteg sematikus ábrája és SEM-felvételei (a). A kék színü vízcseppek nem nedvesítik a kialakított filmet, míg az apoláros, sárga színü (szudán I) n-hexános festékoldat szétterül a rétegen, de ezt követően fotodegradációt szenved (b).

58. ábra. A kompozit rétegek felületén adszorbeálódott $S$. aureus, E. coli és $P$. aeruginosa baktériumok által felvett kristályibolya festék optikai denzitás $\left(620 \mathrm{~nm}\right.$ hullámhossznál, OD $\left._{620}\right)$ értékeinek alakulása az LDO tartalom (m/m\%) függvényében.

59. ábra. A polimer szigetekkel részlegesen borított LDO lamelláról készített reprezentatív SEM felvétel (a). Az S. aureus baktérium sejtek kolonizációja a hidrofil tulajdonságú LDO lamellán (b).

60. ábra. A $80 \mathrm{~m} / \mathrm{m} \%$ LDO tartalmú kompozit rétegen megtapadt $P$. aeruginosa (a/1 és a/2), E. coli (b/1 és b/2) és $S$. aureus (c/1 és c/2) baktérium sejtekről készült egy-egy reperezentatív SEM felvétel.

61. ábra. Az élö (zöld) és inaktivált (piros) Pseudomonas aeruginosa baktérium sejtekröl fluoreszcens mikroszkóppal készült felvételek, a $80 \mathrm{~m} / \mathrm{m} \%$ LDO tartalmú kompozit rétegen 1 és 2 óra bevilágítási idő elteltével.

62. ábra. A fluoreszcens mikroszkóppal készült felvételek alapján számolt élő és inaktivált Pseudomonas aeruginosa baktérium sejtek \%-os megoszlása a megvilágítás idő függvényében.

63. ábra. Az elöállított HAp porminta diffraktogramja (a) és a kiindulási HAp mintáról készült reprezentatív TEM felvétel (b).

64. ábra. A kiindulási $\mathrm{HAp}$ és $\mathrm{TiO}_{2}(\mathrm{P} 25)$, valamint a fizikai keverék és csapadékképzéssel előállított 40/60 m/m\% összetételü $\mathrm{TiO}_{2} / \mathrm{HAp}$ porminták röntgendiffraktogramjai (a), nitrogén adszorpciós izotermái (b) és t-Plot ábrázolása (c).

65. ábra. A $60 / 40 \mathrm{~m} / \mathrm{m} \%$ töltőanyag/ p(EA-co-MMA) aránnyal rendelkező filmekröl készült reprezentatív SEM felvételek. A filmekben a $\mathrm{TiO}_{2} / \mathrm{HAp}$ szervetlen töltőanyag összetétele: 0/60 (a), 12/48 (b), 24/36 (c), 36/24 (d), 48/12 (e) és 60/0 m/m\% (f).

66. ábra. A kompozit filmek reprezentatív SEM- EDX felvételei HAp lamellák hiányában $\left(60 \% \mathrm{TiO}_{2} /\right.$ $40 \%$ p(EA-co-MMA)) (a) és jelenlétében (36\% $\mathrm{TiO}_{2} / 24 \% \mathrm{HAp} / 40 \%$ p(EA-co-MMA)) (b).

67. ábra. Az etanol modellmolekula $S / G$ határfelületen történő fotodegradációja a $40 \mathrm{~m} / \mathrm{m} \%$ polimerrel rendelkező kompozit filmeken. A $\mathrm{HAp} / \mathrm{TiO}_{2}$ arány szisztematikusan változott a kompozit rétegekben. A beszúrt kép a metilénkék festékmolekulák adszorpcióját mutatják be HAp jelenléte, ill. mellőzés esetén a kompozit rétegből. 
68. ábra. $\mathrm{Az}$ elbontott $\mathrm{EtOH}$ koncentráció változása a kompozit $\mathrm{TiO}_{2}$ tartalmának függvényében. $\mathrm{A}$ kompozit rétegekben a katalizátor $\left(\mathrm{HAp} / \mathrm{TiO}_{2}\right.$ keverék) $60 \mathrm{~m} / \mathrm{m} \%$ és a p(EA-co-MMA) 40 m/m\%.

69. ábra. A vékonyrétegben lévő kötő polimer degradációjának vizsgálata HAp lamellák jelenlétében és mellőzése esetén. Alkalmazott fényforrás: $\operatorname{LED}\left(\lambda_{\max }=405 \mathrm{~nm}\right)$.

1. táblázat. A HAp szintézismódszereinek hatása a morfológiára és a részecskeméretre.

2. táblázat. A KYNA kioldódási profiljaira alkalmazott kinetikai modellek alapján kapott paraméterek.

3. táblázat. A Na-montm., $\mathrm{Ag}^{0}$-montm. és $\mathrm{LDH} / \mathrm{Ag}^{0}$-montm. minták kisszögü röntgenszórás (SAXS) mérésekből meghatározott tömeg fraktál $\left(\operatorname{Dim}_{\mathrm{m}}\right)$, felület fraktál $\left(\operatorname{Dim}_{\mathrm{s}}\right)$, Porod-konstans $\left(\mathrm{K}_{\mathrm{p}}\right)$ és $\mathrm{K}_{\mathrm{p}} / \mathrm{Q}$ (belső specifikus felülettel arányos $\mathrm{S} / \mathrm{V}$ ) értékek.

4. táblázat. $\mathrm{Az} \mathrm{LDO} / \mathrm{p}(\mathrm{PFDAk})$ hibrid rétegek névleges és termogravimetriásan meghatározott LDO tartalma, valamint a rétegek számolt porozitása és a meghatározott degradációs hőmérséklet értékek.

5. táblázat. A HAp, $\mathrm{TiO}_{2}(\mathrm{P} 25)$ és $\mathrm{TiO}_{2} / \mathrm{HAp}$ mintákra meghatározott fajlagos felület értékek $\left(\mathrm{a}^{\mathrm{s}}\right)$ nitrogén adszorpciós (BET) és SAXS mérések alapján, valamint a mintákra meghatározott gerjesztési küszöbenergia értékek (Eg).

\section{Melléklet ábrái}

1. M ábra. A különböző koncentrációjú benzoesav-oldatok abszorbancia spektrumai (a), ill. az azokból meghatározott kalibrációs egyenes (b).

2. M ábra. $\mathrm{A} \mathrm{H}_{2} \mathrm{O}_{2}$ kalibrációs oldatsorozat alapján meghatározott kalibrációs egyenes.

3. M ábra. A kinurénsav-oldat kalibrációs sorozatának abszorbancia spektrumaiból meghatározott kalibrációs egyenes $\mathrm{pH}=6,70$ (a) és 1,5 (b) értéken.

4. M ábra. A különbözö töménységü $\mathrm{Ag}^{0}$-montmorillonit szuszpenziók abszorbancia spektrumai (a) és az azok alapján meghatározott kalibrációs egyenes (b).

5. M ábra. $\mathrm{A} \mathrm{TiO}_{2}$ jelenlétében előállított $\mathrm{HAp}$ minták (csapadékképzéssel elöállított $\mathrm{TiO}_{2} / \mathrm{HAp}$ ) szórásgörbéinek Porod féle reprezentációja $\left(\ln \left(h^{3} \mathrm{I}\right)\right.$ ábrázolása a $h^{2}$ függvényében) (a) és a minták sematikus ábrázolása (b).

6. M ábra. A kiindulási $\mathrm{TiO}_{2}$ és $\mathrm{HAp}$, valamint 40/60 m/m\%-os összetételü (fizikai keverék és csapadékképzéssel elóállított) $\mathrm{TiO}_{2} / \mathrm{HAp}$ minták diffúz-reflexiós spektrumai. Szaggatott vonallal a $\lambda_{\max }=405 \mathrm{~nm}$-es LED fényforrás emissziós spektruma. 


\section{Bevezetés és célkitűzések}

Előnyös és tervezhető tulajdonságaiknak köszönhetően a különböző kompozit anyagok egyre nagyobb szerepet töltenek be napjainkban, hiszen a komponensek társításával kialakított összetett anyagok gyakran előnyösebb tulajdonságokkal rendelkeznek a tiszta alkotóelemek által képzett rendszereknél. A kompozit, vagy hibrid anyagok általában két, vagy több anyag kombinációjaként állíthatók elő, ahol egy folytonos mátrix fázisban oszlatunk el egy diszperz fázist.

Doktori munkám gerincét funkcionális kompozit anyagok, valamint azok komponenseinek szintézise és anyagszerkezeti jellemzése jelentette. Olyan összetett rendszereket állítottam elö, melyekben döntően polimer alapú folytonos mátrixban különböző lamellás szerkezettel rendelkező szervetlen töltőanyagokat oszlattam el és vizsgáltam az így kapott hibrid kompozit rendszerek szerkezeti tulajdonságait, ill. a komponensek társítása révén kialakult új összetett anyagok előnyös anyagi tulajdonságait. Értekezésem fő motivációja volt a kapott komponensek társítása révén a kompozitok különböző alkalmazási lehetőségeit (pl. orvosi/orvosbiológiai hatóanyag kapszulázás, szabályozott hatóanyag leadás, öntisztuló felületek kialakítása stb.) is bemutatni.

A kialakított kompozitok folytonos fázisát különböző hidrofilitással rendelkező poliakrilátok adták, még töltőanyagként lamellás szerkezettel rendelkező réteges kettős hidroxidot (LDH), réteges kettős oxidot (LDO), montmorillonitot és hidroxiapatitot (HAp) alkalmaztam.

Ennek során célom volt többek között nagy fajlagos felülettel és felületi töltéssürüséggel, így jelentős anioncsere kapacitással rendelkező LDH lamellák szintézise, ahol a lamellák rétegközi terébe kinurénsav (KYNA) interkalációját kíséreltem meg. Az LDH hordozó pH-függő oldódási, valamint az interkalált KYNA fekélyellenes tulajdonságait felhasználva, célul tüztem ki olyan interkalációs kompozit elöállítását, mely a hatóanyag tartalmát gasztrointesztinális körülmények között - orvosbiológiai szempontból optimális koncentrációban és idő alatt - szabályozottan adja le.

A lamellás szerkezetü LDH mellett különleges, anyagszerkezeti tulajdonságokkal és gömbszerü morfológiával rendelkező LDH előállítását és jellemezését terveztem. Ezzel kapcsolatban egyrészt azt kívántam bemutatni, hogy az így előállított kationos LDH - változtatható felületi töltéssürüségének köszönhetően - alkalmas pH- függő koherens szerkezet kialakítására. Ehhez ellentétes töltésü, azaz anionos komponensként ezüst- nanorészecskékkel funkcionalizált montmorillonit lamellákat szintetizáltam és jellemeztem, majd igazolni kívántam, hogy a komponensek alkalmasak külső stimulus $(\mathrm{pH})$ által indukált antibakteriális gélek kialakítására.

Célom volt annak igazolása is, hogy a gömbi morfológiájú LDH kalcinálása által kapott fotokatalitikus tulajdonságokkal rendelkező LDO töltőanyag alkalmas fotokatalitikus és antibakteriális tulajdonságokkal rendelkező kompozit vékonyrétegek szintézisére. Mindamellett az 
LDO részecskék sugárirányú lamellák által nyújtott érdes felületének köszönhetően a kompozit vékonyrétegek nedvesedési tulajdonságait is szabályozni tudtam.

Végül kitüzött céljaim között szerepelt olyan kompozit rétegek elöállítása, melyek megnövelt fotokatalitikus hatásfokkal rendelkezzenek. A biokompatibilis és lamellás szerkezetü HAp töltőanyag alkalmazásával olyan $\mathrm{TiO}_{2}$ tartalmú poliakrilát alapú kompozit bevonatokat terveztem előállítani, melyekben a HAp komponens által megnövekedett fotokatalitikus hatásfok mellett a részecskék rögzítésére alkalmazott szerves polimer mátrix nemkívánatos fotooxidációja visszaszorítható. 


\section{Irodalmi áttekintés}

\subsection{Kompozitok és kompozit alapú felületek}

A kompozitok, vagy társított anyagok olyan összetett rendszerek, amelyek legalább két komponensből állnak és az alkotók társításával előnyösebb tulajdonságok érhetők el. Az alkotók kémiai összetétele és legtöbbször alakja is különbözik [1]. Az egyik komponens a folytonos mátrix, mely körülveszi a másik alkotót, a diszperz fázist. A kompozitokkal olyan tulajdonságok valósíthatók meg, melyek külön-külön nem hozhatók létre.

A kompozit anyagok egyik legkorábbi felhasználására példa, hogy már az ókori mezopotámiaiak is használtak ilyen heterogén rendszereket házaik építése során i.e. 3400 körül. A sár és a szalma összekeverésével olyan téglákat készítettek, amelyek ellenálltak mind a préselésnek, mind a szakadásnak, így kiváló építőelemeket képeztek [2].

Az első modern kompozit anyag az üvegszál volt [3]. Ma még széles körben használják hajótestekhez, sportfelszerelésekhez, építőelemekhez és sok autó felépítéséhez [3]. A kompozit mátrixa műanyag, az erősítése pedig üvegből készült, melyet finom szálakká alakítottak és textíliává fontak [3]. Önmagában az üveg nagyon erős, de törékeny. A műanyag mátrix összetartja az üvegszálakat és megvédi őket a sérülésektől.

A kompozitok előállítása jellemzően kétféle módon történhet [1]. Az egyik folyamat során a komponenseket (a mátrixot és a diszperz fázist) külön állítják elő, majd utólag keverik össze [4]. A másik út során, a kompozitokat in situ állítják elő (pl. szálas vagy lemezes eutektikumok előállítása [5]). Többféle szempont szerint csoportosíthatók, mint például anyagpárok (fém/fém, fém/kerámia, polimer/üveg, stb), mátrix (fém, kerámia, polimer mátrixú), komponensek morfológiája (szemcsés, szálas, lemezes, réteges) szerint [4]. Elmondható, hogy napjainkban a kompozitféleségek közül a polimer mátrixú kompozitok használata a legelterjedtebb, ezen belül is a leggyakrabban használt az üvegszál/polimer [6], szénszál/polimer [7]; továbbá számos esetben két vagy többféle erösítőszálat is alkalmaznak ugyanazon mátrixban [8].

A polimer mátrix sajátságainak módosítása szervetlen vegyületek beépítésével is történhet, mely során a kialakított kompozitok új tulajdonságokra tehetnek szert. A szervetlen töltőanyagok típusa is rendkívűl széles skálán változhat. Jól ismert, hogy szervetlen töltőanyagok régóta használatosak a különböző tulajdonságú müanyagok előállításában, például a szilárdság és a szívósság növelésére, vagy a gyúlékonyság csökkentésére [1,4].

A szervetlen-szerves hibrid kompozitok különleges kémiai sajátságaiknak köszönhetően egyre elötérbe kerülnek innovatív ipari alkalmazások és fejlesztések területén [9]. Ilyen hibrid 
nanokompozitok egyik képviselője pl. az agyagásvány-polimer nanokompozitok [10], melyek előnye inkább kis mennyiségü töltőanyag alkalmazása esetén jelentős, ugyanis nagyobb mennyiségben a kompozit sürüségét növelheti, ezáltal annak rugalmasságát vagy átláthatóságát ronthatja. Az agyagásvány tartalmú nylon-6 nanokompozit előállításában és fejlesztésében a TOYOTA cég úttörő szerepet töltött be az 1980-90-es években [11, 12]. Jelenleg a fejlesztéseket szinte minden polimerre, ill. müanyagra kiterjesztették, beleértve a poli-propilént (PP) [13], a polietilént [14], a poli-sztirént [15], a poli-vinil-kloridot [16], az akrilnitril-butadién-sztirol (ABS) polimert [17], a polimetil-metakrilátot [18], polietilén-oxidot (PEO) [19], vagy epoxi-gyantát [20].

\subsection{Lamellás szerkezettel rendelkező kompozit töltőanyagok}

\subsubsection{Réteges kettős hidroxidok (LDH)}

A természetben is előforduló réteges kettős hidroxidok (LDH) olyan szervetlen anyagok, melyek az agyagásványokhoz hasonló szerkezetük és tulajdonságaiknak köszönhetően, egyre több alkalmazási területen kerülnek előtérbe.

Az eredetileg felfedezett LDH az ásványi hidrotalcit (magnézium-alumínium hidroxikarbonát: $\mathrm{Mg}_{6} \mathrm{Al}_{2}(\mathrm{OH})_{16}\left(\mathrm{CO}_{3}\right) \cdot 4\left(\mathrm{H}_{2} \mathrm{O}\right)$, melyet először Norvégiában, Snarum területén találtak [21]. Carl Christian Hochstetter (1842) volt az első, aki beszámolt a hidrotalcitról, melyet fehér, gyöngyszerü csillogású anyagként írt le. Nevét magas víztartalmának (hidro) és a talkumhoz (talkum) hasonló tulajdonságának köszönheti [21]. Az LDH szerkezetét és tulajdonságait Allmann (1968) és Taylor (1969) mutatta be röntgendiffrakciós vizsgálatokkal [22]. Az LDH-ák brucit típusú $\left(\mathrm{Mg}(\mathrm{OH})_{2}\right)$ oktaéderes rétegekből épülnek fel, melyekben két- és háromértékü kationok helyezkednek el és izomorf helyettesítéssel pozitív töltésfelesleg alakul ki. Ennek köszönhetően a rétegek pozitív töltéssel rendlekeznek. A rétegek között vízmolekulák foglalnak helyet, továbbá a rétegek pozitív töltését semlegesítő anionok. A hidrotalcit ásványok kémiai összetétele a következő általános képlettel adható meg:

$$
\left[\mathrm{M}^{2+}{ }_{1-\mathrm{x}} \mathrm{M}^{3+}{ }_{\mathrm{x}}(\mathrm{OH})_{2}\right]^{\mathrm{b}+} \cdot[\mathrm{A} \mathrm{b} / \mathrm{n}]^{\mathrm{n}-} \cdot \mathrm{mH}_{2} \mathrm{O}
$$

ahol az $M^{2+}$ kétértékü $\left(\mathrm{Mg}^{2+}, \mathrm{Ca}^{2+}, \mathrm{Zn}^{2+}\right), M^{3+}$ háromértékü $\left(\mathrm{Al}^{3+}, \mathrm{Cr}^{3+}, \mathrm{Fe}^{3+}, \mathrm{Co}^{3+}\right)$ kationok, $x$ értéke 0,2-0,4 között változhat, $A$ a rétegek közötti anionok $\left(\mathrm{OH}^{-}, \mathrm{Cl}^{-}, \mathrm{NO}_{3}{ }^{-}, \mathrm{CO}_{3}{ }^{2-}, \mathrm{SO}_{4}{ }^{2-}\right), n$ az anionok töltését, míg $m$ a vízmolekulák számát jelöli. Az anionok mérete nagyban befolyásolja a bázislapok távolságát, mely $d_{L}=7,6$ - 11 Å között, a rétegek vastagsága 4,7 - 4,9 Å tartományban változhat (1. ábra). 


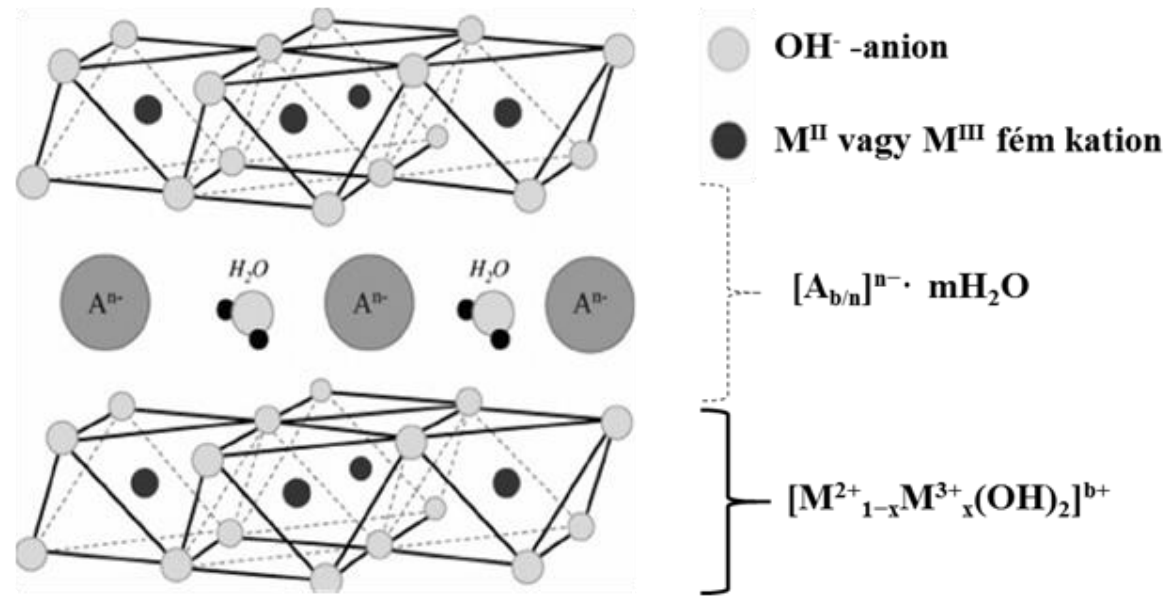

1. ábra. Az LDH-ák szerkezeti felépítésének sematikus ábrázolása.

A természetben előforduló réteges szerkezetủ keverék hidroxidok mesterségesen is előállíthatók laboratóriumi, ill. ipari méretekben egyaránt. Az előállított LDH-ák tulajdonságai közül kiemelendő, hogy a rétegek homogén töltés eloszlással és kitűnő anioncsere képességgel bírnak. A rétegközi terükben lévő anionok változatos méretü szervetlen és szerves anionokkal is kicserélhetők [23]. További tulajdonságai között említhető, hogy változó töltéssürüséggel és nagy fajlagos felülettel rendelkeznek, továbbá olcsón, nagy mennyiségben is könnyen elöállíthatók.

Anioncserélö képességüknek, változatos összetélüknek, biokompotaibilitásuknak és számos egyéb előnyös tulajdonságaiknak köszönhetően a katalízis [24], az elválasztás [25], a biomedicina [26], a gyógyszertároló/szállító rendszerek [27], környezetvédelmi alkalmazások [28], stb. területeken is potenciálisan felhasználható anyagok.

Az elmúlt években számos tanulmányt olvashatunk LDH-ák szintéziséről, melyek között találhatunk néhány egyszerü és drága eljárást egyaránt. Ezen sokrétü anyag előállítására javasolt módszerek közül leggyakrabban az úgynevezett együtt lecsapásos, szol-gél, ill. kalcinálásrehidratálás (memória-effektus) módszerét részesítik előnyben.

Az együtt lecsapásos (ko-precipitációs) módszer a leggyakrabban alkalmazott módszer az LDH közvetlen előállítására. Legtöbbször $\mathrm{Mg} / \mathrm{Al}, \mathrm{Zn} / \mathrm{Al}$ [29] valamint $\mathrm{Ca} / \mathrm{Al}$ [30] tartalmú anyagokat állítanak elő, de bizonyos esetekben szokatlan, pl. Ba/Fe [31], Mn/Cr [32] LDH-k előállításáról is olvashatunk. Szintézisük során különféle két- és háromértékü fém kationok megfelelő aránya és az oldat pH-jának növelésével (pl. NaOH-dal kialakított lúgos pH-án) vagy karbamid hidrolízisével állíthatók elő. Az együttlecsapásos módszert gyakran emelt hőmérsékleten (pl. $80{ }^{\circ} \mathrm{C}$-on) végzik, melyet egy öregítési folyamat követhet. A lecsapási, ill. az öregítési folyamat hőmérséklete és időtartama jelentős befolyással van a kialakult anyagok szerkezetére, kristályossági fokára, ill. morfológiájára. A karbamid alapú lecsapásos módszer esetén a végtermékek jobb kristályosságot és 
jobb részecskeméret-eloszlást tesz lehetővé, mivel a karbamid hidrolízise nagyon lassan megy végbe [33].

Az LDH egyedülálló tulajdonsága, hogy kalcinálása és rehidratálása után visszanyeri eredeti szerkezetét. A mintákat enyhe hőmérsékleten $\left(400-500{ }^{\circ} \mathrm{C}\right)$ kalcinálva a rétegek közötti vízmolekulák, az LDH hidroxilcsoportjai és az interkalált anionok teljesen eltávolíthatók és a kiindulási anyag kémiai összetételétől függően, keverék oxidokat kapunk. A kapott oxid minták hidrotermális módszerrel visszaállíthatók, visszakapva az eredeti réteges szerkezetet [34].

Az LDH-ák jellemző tulajdonságai mellett megemlíthetjük, hogy felületük mintázható. Tetszőleges méretü és mintázatú felszínnel rendelkezhetnek azok az LDH anyagok, amelyeket úgynevezett "inverz opál módszer"-rel állítanak elő, polisztirol gyöngyök, templátként történő felhasználásával. Végeredményeként egy jól tervezett, makropórusos-LDH struktúrát állíthatunk elő [35]. Az így kialakított három-dimenziós makropórusokba sokféle aniont lehet beépíteni. Xu és munkatársai olyan üreges LDH gömböket állítottak elő, melyek teljesen különböző morfológiát mutatnak. Munkájukban $\mathrm{CoFe}^{\mathrm{II}} \mathrm{Fe}^{\mathrm{III}}-\mathrm{LDH}$-át szintetizáltak. Az előállítás során „virág” és „málna” alakú üreges LDH gömböket kaptak (2. ábra) [36].
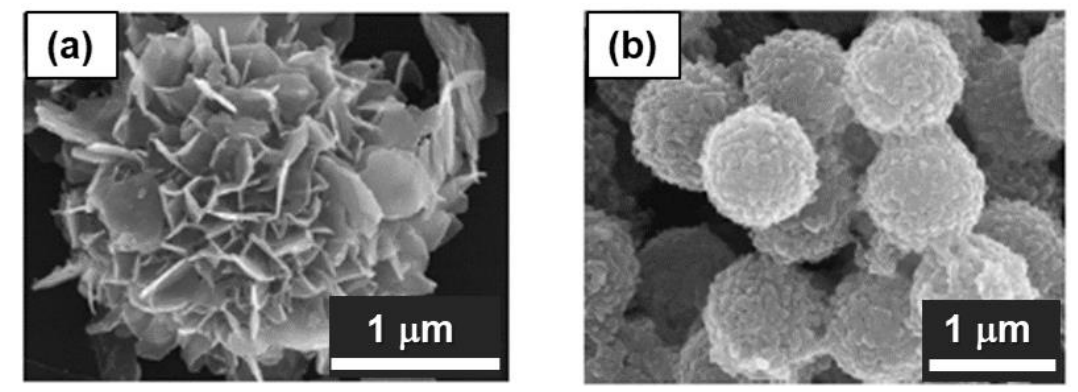

2. ábra. A „virág” (a) és „málna” (b) alakú üreges LDH gömbök egy-egy példaként bemutatott SEM felvétele [36].

A ,virágszerü” LDH esetében a lamellák az élükre állítva, a „málnaszerü” LDH esetében pedig, a lamellák egymáson helyezkednek el a templátként szolgáló polisztirol-szulfonát (PSS) gyöngyökön (3. ábra).
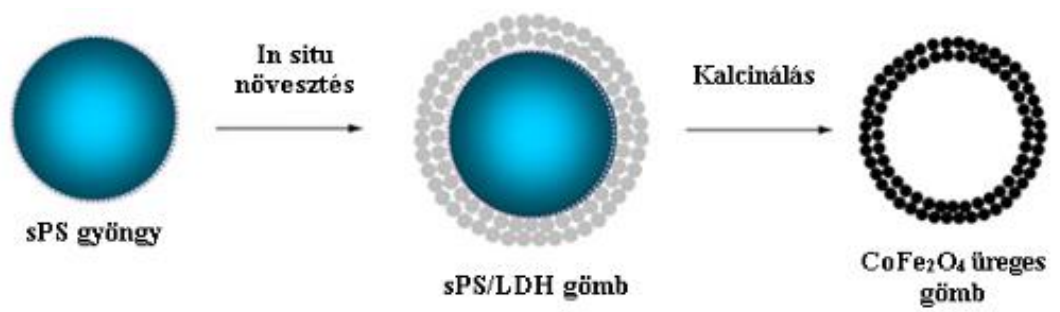

3. ábra. A CoFe ${ }^{\mathrm{II}} \mathrm{Fe}^{\mathrm{III}}$-LDH gömb-héj szerkezet kialakulásának sematikus ábrája [36]. 
Az LDH szintézise során együtt lecsapásos módszert alkalmaztak és a $\mathrm{NaOH}$-oldat adagolási sebességének szabályozásával jutottak el a „virág” és „málna” alakzat kialakulásához. A „virág” alakú LDH esetében lassú ( $0,14 \mathrm{~mL} /$ perc), a „málna” alakú LDH esetében pedig gyors ütemü (4,35 $\mathrm{mL} /$ perc) adagolást végeztek (elérve a $\mathrm{pH}=7$-es értéket). A kialakult PSS/ LDH gömb alakú kompozitokból kalcinálással eltávolították a polisztirol-szulfonátot. Végeredményként üreges $\mathrm{CoFe}_{2} \mathrm{O}_{4}$ fém-oxid gömböket kaptak.

A fentiekben bemutatott módszertől eltérően Zheng és munkatársai egy lépésben állítottak elő „virágszerü” gömb LDH-át karbamid alkalmazásával. Az így előállított ZnMgAl-LDH magas kristályossági fokot és nagy fajlagos felületet eredményezett, mely kedvezőnek mutatkozhat adszorpciós folyamatok vizsgálatában [37]. Az ilyen módszerrel előállított „virágszerü” gömbi LDH kialakulásának hátterét Wang és munkatárasai vizsgálták Mg/Al-LDH szintézise során [38]. Munkájuk során hidrotalcitot homogén csapadékképződéssel és hidrotermális módszerrel állítottak elő, karbamid jelenlétében, magas hőmérsékleten $\left(\sim 125^{\circ} \mathrm{C}\right)$. A 4. ábrán a karbamid jelenlétében kialakuló, gömbi szerkezetü LDH képződésének sematikus folyamatát tüntettem fel.

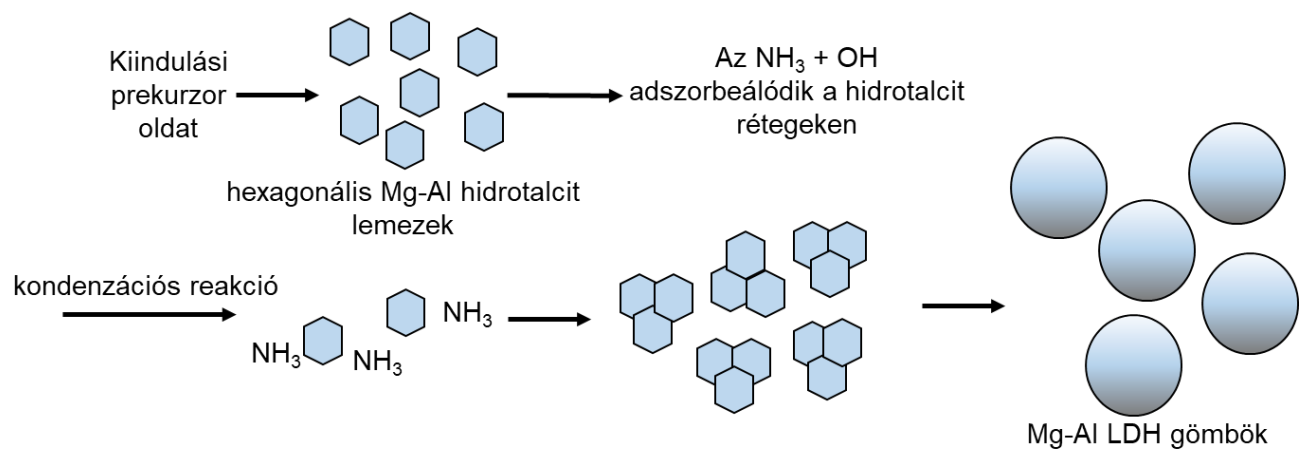

4. ábra. A kialakuló gömb alakú Mg/Al-LDH sematikus ábrája [38].

Mint látható, az LDH lemezek kialakulásának mechanizmusában fontos szerepet játszik a karbamid hidrolízise. Az együtt lecsapásos Mg-Al hidrotalcit kialakulásának folyamata során az alábbi reakciók mennek végbe [39]:

$$
\begin{aligned}
& \mathrm{CO}\left(\mathrm{NH}_{2}\right)_{2}+2 \mathrm{H}_{2} \mathrm{O} \rightarrow 2 \mathrm{NH}_{4}^{+}+\mathrm{CO}_{3}^{2-}\left(\mathrm{NH}_{4}\right)_{2} \mathrm{CO}_{3} \\
& \rightarrow 2 \mathrm{NH}_{3} \uparrow+\mathrm{CO}_{2} \uparrow+\mathrm{H}_{2} \mathrm{O} \mathrm{NH} \mathrm{NH}_{3}+\mathrm{H}_{2} \mathrm{O} \leftrightarrow \mathrm{NH}_{4} \mathrm{OH} \\
& \leftrightarrow \mathrm{NH}_{4}^{+}+\mathrm{OH}^{-} \mathrm{CO}_{2}+\mathrm{H}_{2} \mathrm{O} \leftrightarrow \mathrm{H}_{2} \mathrm{CO}_{3} \leftrightarrow \mathrm{H}^{+}+\mathrm{HCO}_{3}^{-} \\
& \leftrightarrow 2 \mathrm{H}^{+}+\mathrm{CO}_{3}^{2-} 2 \mathrm{OH}^{-}+(\mathrm{x} / 2) \mathrm{CO}_{3}^{2-}+(1-\mathrm{x}) \mathrm{Mg}^{2+} \\
& +\mathrm{x} \mathrm{Al}^{3+}+\mathrm{y} \mathrm{H}_{2} \mathrm{O} \rightarrow\left[\mathrm{Mg}_{1-\mathrm{x}} \mathrm{Al}_{\mathrm{x}}(\mathrm{OH})_{2}\right]\left(\mathrm{CO}_{3}\right)_{\mathrm{x} / 2} \cdot \mathrm{yH}_{2} \mathrm{O} \downarrow
\end{aligned}
$$


A megemelt hőmérsékleten és nyomáson a keletkező gázok $\left(\mathrm{NH}_{3}\right.$ és $\left.\mathrm{CO}_{2}\right)$ az oldatba oldódnak, buborékot képeznek és arra késztetik a lamellákat, hogy aggregáció menjen végbe a gáz-folyadék határfelületen. Ennek oka, hogy a gáz-folyadék határfelület alacsony felületi energiával rendelkezik, könnyü gócképződést és növekedést eredményezve.

\subsubsection{Montmorillonit (Na- bentonit)}

A réteges szerkezetü szilikátok nagy jelentőséggel bírnak, jellegzetes képviselőjük a montmorillonit $\left(\mathrm{Al}_{2}(\mathrm{OH})_{2} \mathrm{Si}_{4} \mathrm{O}_{10}\right)$. Kristályrácsuk kétdimenziós rétegekből épül fel, melyek vastagsága kb. $1 \mathrm{~nm}$, viszont laterális, oldalirányú kiterjedésük a néhány nanométertől több mikrométerig terjedhet. A montmorillonitot alkotó rétegek tetraéderesen koordinált Si atomokból (szilícium-dioxid tetraéderek) és oktaéderesen koordinált alumínium-hidroxid vagy magnéziumhidroxid síkokból állnak (5. ábra). Sokrétü alkalmazásuk alapja, hogy a természetben nagy mennyiségben hozzáférhetők, valamint mesterségesen is előállíthatók.

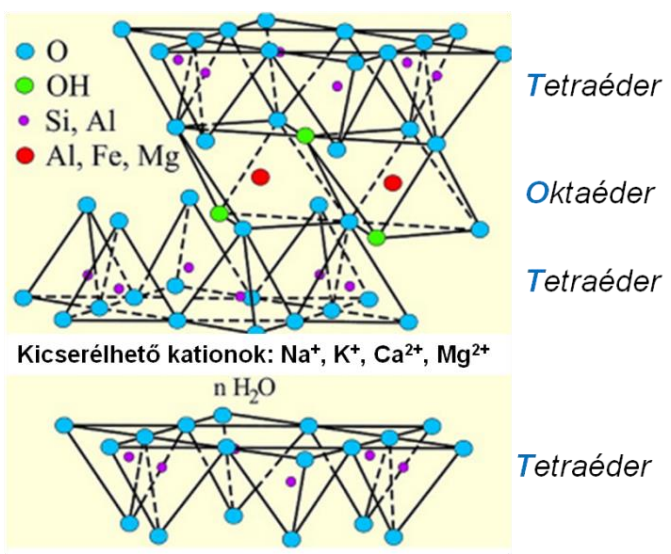

5. ábra. A montmorillonit (2:1 típusú rétegszilikát) szerkezete [40].

További jellegzetessgégük, hogy jelentős kationcsere-kapacitással rendelkeznek (jellemzően 1 meq/g érték), ugyanis az oktaéderben a háromértékü kationt kétértékü kation (pl. magnéziumion, vas(II)-ion), ill. a tetraéderben a négyértékü szilíciumot háromértékü kation (pl. alumíniumion) helyettesíti. Így a fellépő negatív töltéstöbbletet az interlamináris $\mathrm{Na}^{+}-, \mathrm{Li}^{+}$- és $\mathrm{Ca}^{2+}$-ionok ellensúlyozzák. Víz hatására erős duzzadási tulajdonsága mellett rétegei közzé egyéb kationok is beépülhetnek. Ezen tulajdonságuk alkalmassá teszi őket arra, hogy a rétegek közé különböző (pozitív töltéssel) rendelkező szerves [41], vagy szervetlen [42] anyagokat juttassunk.

A bentonitok másik igen gyakori alkalmazása a borászatban van. A legfontosabb fehérje csökkentő anyag, kationcsere-kapacitásának köszönhetően. A Na-bentonit erősen duzzad 
ellentétben a Ca-bentonittal, így alkalmas rá, hogy adszorpció révén eltávolítsuk az oldott fehérjéket és pelyhes üledéket képezzünk (flokkuláció) [43].

További fontos terület, ahol széles körben alkalmazzák, az a gyógyszeripar. Nemcsak a gyógyszerkészítmények bevonására, síkossá tételére alkalmazzák, hanem aktív hordozóként, valamint hatóanyagok interkalálására és leadására is [44, 45].

A montmorillonit lamellák kationcserélő képességét arra is felhasználhatjuk, hogy a Na-ionokat átmeneti-, vagy nemesfém ionokra cseréljük, majd azokat utólag kémiai, vagy fény által történő bevilágítás útján redukáljuk. Ennek gyakorlati haszna, hogy a különböző nanoméretü fémek (pl. ezüst és réz), valamint egyes félvezető oxidok (pl. cink-oxid) alakíthatóak ki a lamellákon, amelyek akár antimikrobiális tulajdonságokkal is rendelkezhetnek [46, 47]. Az így kialakított fém nanorészecske tartalmú lamellák -a hordozó által megnövelt felületnek köszönhetően- ígéretes katalizátor hordozónak is bizonyulhatnak [45].

\subsubsection{Hidroxiapatit (HAp)}

A gerincesek csontozatának legfontosabb alkotóeleme a hidroxiapatit. A csontok és a fogak fö ásványi alkotóelemei a kalcium-foszfát $(\mathrm{CaP})$ sók [48, 49]. Amint az a 6. ábrán látható, a csont és más meszesített szövetek természetes anizotróp kompozitoknak tekinthetők, amelyek fehérje mátrixba ágyazott bio-ásványokból, más szerves anyagokból és vízből állnak [50]. A CaP-sók közül a hidroxiapatit $\left(\mathrm{Ca}_{10}\left(\mathrm{PO}_{4}\right)_{6}(\mathrm{OH})_{2}, \mathrm{HAp}\right)$ a termodinamikailag legstabilabb kristályos fázis [49].

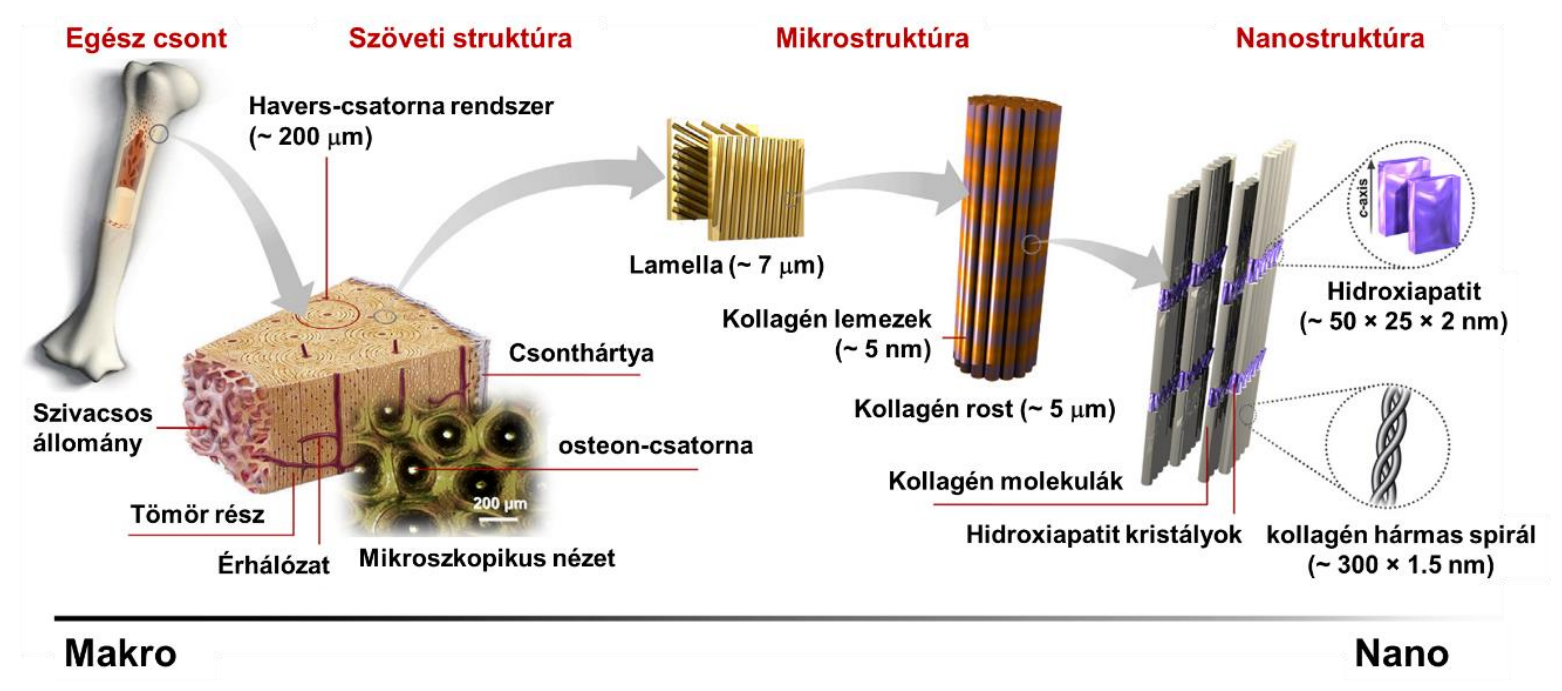

6. ábra. A csontszerkezet hierarchikus felépítésének sematikus ábrája, mikro- és nano-skálán bemutatva [51]. 
Hidroxiapaitot szintetikusan is előállíthatunk. Az elmúlt 10-15 évben megnőtt az érdeklődés ezen anyagcsalád iránt, hiszen olyan kiváló tulajdonságokkal rendelkeznek, mint a biokompatibilitás [52, 53], a biopolimerekhez való affinitás [54], ill. elősegítheti az új csontok növekedését az oszteokondukciós mechanizmuson keresztül anélkül, hogy helyi vagy szisztémás toxicitást, gyulladást vagy idegentest választ okozna [55, 56]. Felhasználásuk az emberi szervezet szempontjából fontosnak bizonyult; ortopédiában, sebészetben, fogászatban nagy sikerrel alkalmazzák. Jó bioaktivitási és biokompatibilitási tulajdonságának köszönhetően a HAp kemény vagy lágy szövetekbe könnyen beépíthető, így a belölük előállított kompozitok, implantátumok, mücsontok készítése és fejlesztése a szakorvosok és kutatók érdeklődését képezi.

Az elmúlt évtizedben számos különféle módszerrel állítottak elő HAp nanorészecskéket. Az eddig ismeretes változatos szintézismódszerek mind befolyásolják az előállított HAp minták összetételét, kristályszerkezetét, morfológiáját, méretét, fajlagos felületét, porozitását és nem utolsósorban a felhasználási területüket. Az 1. táblázatban láthatjuk, hogy a különféle szintézismódszerekkel, változatos alakkal és mérettel rendlekező HAp minták állíthatók elő. A leggyakoribb szintézismódszerek között szerepel a csapadékos módszer, szol-gél, emulziós és mechanokémiai módszerek.

A nedves kémiai reakciók előnye abban rejlik, hogy kevesebb energiabefektetéssel járnak, a kísérleti paraméterek pontos betartása mellett, az előállított HAp minta szerkezete, morfológiája és átlagos mérete könnyedén befolyásolható. A nedves kémiai módszerek népszerüségét az is mutatja, hogy a megjelent publikációkban több mint 60 \%-ában ezen módszerek alkalmazását preferálják. 
1. táblázat. A HAp szintézismódszereinek hatása a morfológiára és a részecskeméretre. [51].

\begin{tabular}{|c|c|c|c|}
\hline Alak & Megnevezés & Méret & Szintézismódszer \\
\hline & szabálytalan gömb & (I) $5 \mathrm{~nm}-200 \mu \mathrm{m}$ & $\begin{array}{l}\text { ss, mch, cc, hl, sg, ht, em, } \\
\text { sch, cp }\end{array}$ \\
\hline & mikro-, nanogömb & (I) $10 \mathrm{~nm}-1000 \mu \mathrm{m}$ & $\mathrm{mch}, \mathrm{cc}, \mathrm{sg}, \mathrm{ht}, \mathrm{em}, \mathrm{cp}$ \\
\hline & rúd, csö, rost & $\begin{array}{l}\text { (I) } 10 \mathrm{~nm}-150 \mu \mathrm{m} \\
\text { (d) } 10 \mathrm{~nm}-150 \mu \mathrm{m} \\
\text { (a.r.) } 10 \mathrm{~nm}-150 \mu \mathrm{m}\end{array}$ & $\begin{array}{l}\text { ss, mch, cc, sg, ht, em, } \\
\text { cp }\end{array}$ \\
\hline & lemez, pehely & $\begin{array}{l}\text { (l) } 40 \mathrm{~nm}-50 \mu \mathrm{m} \\
\text { (w) } 20 \mathrm{~nm}-35 \mu \mathrm{m} \\
\text { (t) } 5 \mathrm{~nm}-3 \mu \mathrm{m}\end{array}$ & $\mathrm{cc}, \mathrm{hth}, \mathrm{cp}$ \\
\hline & csomagolt nanorudak & $\begin{array}{l}\text { (I) } 200 \mathrm{~nm}-80 \mu \mathrm{m} \\
\text { (w) } 100 \mathrm{~nm}-50 \mu \mathrm{m} \\
\text { (d) } 10 \mathrm{~nm}-13 \mu \mathrm{m}\end{array}$ & $\mathrm{cc}, \mathrm{hl}, \mathrm{hth}, \mathrm{cp}$ \\
\hline & pitypang, virág & $\begin{array}{l}\text { (l) } 600 \mathrm{~nm}-5 \mu \mathrm{m} \\
\text { (d) } 80 \mathrm{~nm}-500 \mathrm{~nm}\end{array}$ & hth, em, cp \\
\hline & levél, pehely, lemez & $\begin{array}{l}800 \mathrm{~nm}-10 \mu \mathrm{m} \text { lemezek } \\
\text { (t) } 20 \mathrm{~nm}-100 \mathrm{~nm}\end{array}$ & k cc, hl, cp \\
\hline & virág & $\begin{array}{l}\text { (I) } 180 \mathrm{~nm}-50 \mu \mathrm{m} \\
\text { (w) } 20 \mathrm{~nm}-10 \mu \mathrm{m}\end{array}$ & cc, hth \\
\hline & porózus mikrogömb & $\begin{array}{l}\text { (d) } 0,5-7 \mu \mathrm{m} \\
\text { pórus: } 20 \mathrm{~nm}-150 \mathrm{~nm}\end{array}$ & hth, $c p$ \\
\hline & $\begin{array}{l}\text { önszerveződő } \\
\text { nanorudak }\end{array}$ & $\begin{array}{l}\text { (d) } 100-150 \mathrm{~nm} \\
\text { (I) } 1-2 \mu \mathrm{m}\end{array}$ & $\mathrm{cp}$ \\
\hline & súlyzó & (d) $2-3 \mu \mathrm{m}$ & $\mathrm{cc}$ \\
\hline
\end{tabular}

HAp partikulumok méretének rövidítése: (l): hosszúság, (d): átmérő, (w): szélesség, (t): vastagság, (a.r.) karcsúság. Szintézismódszerek rövídítése: ss - száraz módszer; mch - mechanokémiai módszer; cc hagyományos csapadékképzéses módszer; hl - hidrolízis; sg - szol-gél módszer; ht - magas hőmérsékleti folyamatok; em - emulziós; sch - szonokémiai módszer; hth - hidrotermális módszer; cp - kombinált eljárások.

A csapadékos módszer alkalmazása esetén $\mathrm{Ca}^{2+}$ - és $\mathrm{PO}_{4}{ }^{3-}$-ionokat tartalmazó vizes oldatokat lúgos pH-án elegyítünk, majd a képződött csapadékot megfelelő körülmények között tartva (öregítve) hidroxiapatit állítható elő. A HAp minta képződése a következő általános reakcióval írható le [51]:

$$
10 \mathrm{Ca}\left(\mathrm{NO}_{3}\right)_{2}+6\left(\mathrm{NH}_{4}\right)_{2} \mathrm{HPO}_{4}+2 \mathrm{H}_{2} \mathrm{O}=\mathbf{C a}_{10}\left(\mathbf{P O}_{4}\right)_{6}(\mathbf{O H})_{2} \downarrow+12 \mathrm{NH}_{4} \mathrm{NO}_{3}+8 \mathrm{HNO}_{3}
$$




\section{3 Öntisztuló felületek}

A természet inspirálta öntisztuló felületek kialakítása egyre nagyobb figyelemnek örvend nem csak a kutatók körében, hanem a különböző iparágak (autó-, repülőgép-, hajó-, építőipar stb.) és egészségügyi intézmények területén is. Ezeknek a felületeknek a legfontosabb tulajdonsága, hogy a rákerülő szennyező anyagokat vagy mikroorganizmusokat képesek eltávolítani, ill. lebontani.

Müködési mechanizmusuk alapján az öntisztító felületek három fő csoportba sorolhatók: (1) szuperhidrofil, (2) szuperhidrofób és (3) fotokatalitikus tulajdonságokat mutató öntisztuló felületek $[57,58]$.

A szuperhidrofil felületekre kerülő vízcseppek szétterülnek és vékony filmréteget képeznek a felszínen (peremszög értékük közel $0^{\circ}$ ), míg a szuperhidrofób felületekre kerülő vízcseppek érintkezési szöge meghaladhatja a $150^{\circ}$-ot. A szuperhidrofil felületek esetében az öntisztuló folyamat úgy történik, hogy a vékony vízréteg „lemossa” a felszínen lévő szennyező részecskéket [57], míg a szuperhidrofób felületek esetében a gömb alakú vízcseppek felszedik az útjukba kerülő szennyezödéseket, miközben legördülnek a felületről [57].

Az öntisztuló felületek másik nagy csoportját a fotokatalitikus tulajdonságokat mutató bevonatok képezik. Az ilyen típusú felületek félvezető fotokatalizátor $\left(\mathrm{pl} . \mathrm{TiO}_{2}\right)$ tartalmuknak köszönhetően megfelelő fényforrással gerjeszthetők és a folyamat során képződő reaktív gyökök reakcióba lépnek a felületre kerülő szerves szennyező anyagokkal és képesek azokat fotodegradálni [58].

\subsubsection{Szuperhidrofób felületek}

Az ún. szuperhidrofób, vagy lótusz-szerü felületek rendkívül magas víztaszító képességgel bírnak, így a felületre jutó vízcseppek legördülnek a felszínükről, ill. vissza is pattanhatnak, ha adott magasságokból a felületre esnek. Szuperhidrofób tulajdonságuk felületi energiájukban és felületi morfológiájukban rejlik. Ha a felületi energia csökken, akkor javul a hidrofób tulajdonság. A kémiai összetételük meghatározza felületi energiájukat és így nagymértékben befolyásolják a nedvesíthetőségüket [59]. Csak a felületi energia csökkenésével azonban önmagában nem érhető el a szuperhidrofób tulajdonság. Például, a teflonszerü felületek poli(tetrafluor-etilén) (PTFE), vagy a - $\mathrm{CF}_{3}$-végü felületek rendelkeznek a legalacsonyabb felületi szabadenergiával (PTFE esetén kb. 22 $\mathrm{mJ} / \mathrm{m}^{2}$ ), így a legjobb hidrofób tulajdonsággal, de a sík felületen vízre meghatározott legnagyobb peremszög értéke csak kb. 110-120 [60]. Így a szuperhidrofób jelleg elérésében nemcsak a kémia összetételnek, hanem a felszín morfológiájának is döntő szerepe van.

A felület érdesítése nagymértékben javíthatja a kiindulási felület nedvesedési tulajdonságait, mely nemcsak a szilárd-folyadék felület növekedésével [61, 62] (Wenzel - állapot, 7. (a) ábra), hanem 
akkor is létrejöhet, ha a levegő csapdába esik egy érdes felület és az azzal érintkező folyadékréteg között (Cassie-Baxter - állapot, 7. (b) ábra). Mivel a levegő hidrofób anyag, ez a levegőcsapda tovább erősíti a felület hidrofób jellegét [63].

(a)

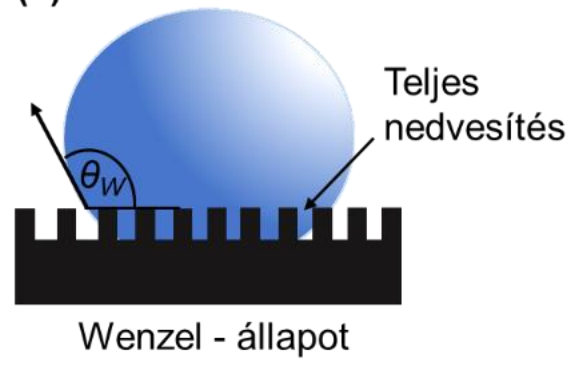

(b)

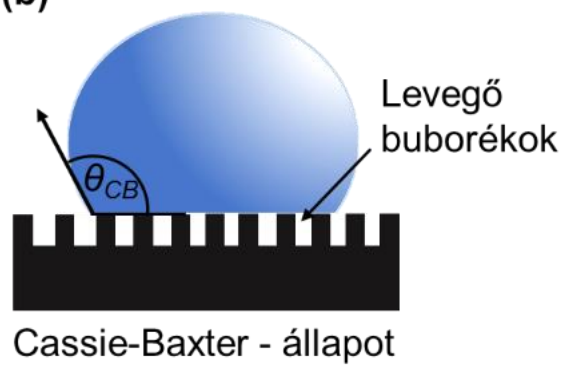

7. ábra. Érdes felületek Wenzel (a) és Cassie-Baxter (b) féle nedvesedési állapotait bemutató sematikus ábrái.

A nagy érintkezési szögek mellett, a szuperhidrofób felületek nagyon alacsony nedvesedési hiszterézist mutatnak $\left(<10^{\circ}\right)$, mely a haladó és hátráló peremszög értékek különbségéből ered. Ez a jelenség a természetben is nagy számban fordul elö. Több növény, például a lótusz (Nelumbo nucifera), a vadkáposzta (Brassica oleracea) és még sok más növény levele, valamint a pillangók szárnyai [64] mind szuperhidrofób felülettel rendelkeznek [65].

Szuperhidrofób felületek kialakításához különféle szerves és szervetlen anyagokat alkalmaznak. A polimer anyagok esetében, melyek általában természetüknél fogva hidrofób jellegüek, a felület mikro- és/ vagy nanoszinten vett érdességének kialakításán van a fő hangsúly. Szervetlen anyagok esetében, melyek általában hidrofil, jól nedvesedő tulajdonságokat mutatnak, a megfelelő felületi érdesség kialakítása után a felületi energiát is le kell csökkenteni, azaz hidrofóbbá kell tenni azt. Szuperhidrofób felületek előállítására számos technikát vizsgáltak és mutattak be. Ezeket két csoportba lehet osztani [66, 67]: (1) alacsony felületi energiával rendelkező anyag felszínének érdesítésével, ill. (2) durva felület módosítása alacsony felületi energiájú anyaggal. Az érdes felületek előállítására különféle módszereket alkalmaznak, mint például szol-gél módszer [68], rétegről rétegre történő kialakítás (layer-by-layer, vagy LbL módszer) [69], de felületi maratással (etching) [70], litográfiával [71], kémiai [72] és elektrokémiai [73] leválasztással (depozicíóval) is kialakítható a megfelelő struktúra.

Alkalmazásuk több területet is érint. Szuperhidrofób bevonatok előállításával öntisztító ablakokat [74], tetőcserepeket [75], textíliákat [76], napelemeket [77] és antimikrobiális felületek [78] alakíthatók ki. Egyik legfontosabb alkalmazásuk a fémek és ötvözetek korróziógátlása. Víztaszító képességük miatt képesek lelassítani a fémek oxidrétegének bomlását, megakadályozván a fémfelület további korrózióját [79]. 


\subsubsection{Antibakteriális felületek}

Az ún. nozokomiális, vagy kórházi eredetű fertőzések kialakulásáért felelős baktériumok és vírusok, ill. gombák elleni fellépés szükségessége miatt a közelmúltban több interdiszciplináris, a nanotechnológiai és a mikrobiológiai eszköztárakat felvonultató megoldás is született [80, 81]. A különböző antibakteriális bevonatok kialakítása rendkívül fontos és kiemelt figyelmet követel kórházi, oktatási intézményekben, ipari létesítményekben, ahol a fertőzések jelentősége igen nagy, és nem utolsósorban otthonainkban is. A felületek fertőtlenítésére számos módszer alakult ki az utóbbi évtizedekben, ezek az eljárások történhetnek fizikai, ill. kémiai úton vagy ezek kombinálásával. Kisméretü eszközök fertőtlenítése leggyakrabban magas hőfokon (fözéssel, gőzöléssel), vagy vegyszerek használatával történhet. Nagy felületek (munkaasztalok, padlók, falak, medencék, csempe- és üvegfelületek, stb.) tisztítása, fertőtlenítése már korlátozottabb, időigényes, valamint további tisztító berendezések igénybevételét vonja maga után, mely további költségnövekedést jelent. Nagy felületek fertőtlenítése leggyakrabban olyan vegyszerek alkalmazásával történik, mely nem csak a környezetünkre, hanem az emberi szervezetre is káros hatással van. Ebből kifolyólag, nagy figyelem övezi azokat az innovatív kutatásokat és megoldásokat, melyek olyan intelligens bevonatokat állítanak elő, melyek lehető teszik az öntisztuló, antibakteriális felületek kialakítását, valamint környezetbarát, emberi szervezetre nem káros hatású, bármilyen felületen alkalmazható, előállításuk költséghatékony.

Ilyen antibakteriális felületek fotokatalizátor tartalmú kompozit rétegek előállításával is kialakíthatók. A $\mathrm{TiO}_{2}$ [82], vagy $\mathrm{ZnO}$ [83] jól ismert fotokatalizátor részecskék, melyek megfelelő hullámhosszúságú fénnyel gerjeszthetők. A folyamat során, a fotonok abszorpcióját követően, az elektronok a vezetési sávba kerülnek, majd gerjesztett állapotba hozzák a vegyértékhéjon elhelyezkedő elektronokat, melyek ilyen módon a vezetési sávba kerülve, pozitív töltésủ lyukakat $\left(\mathrm{h}^{+}\right)$hoznak létre a vegyértékhéjon [84] (8. ábra). Kémiai reakcióban a lyuk oxidációt, az elektron pedig redukciót tesz lehetővé.

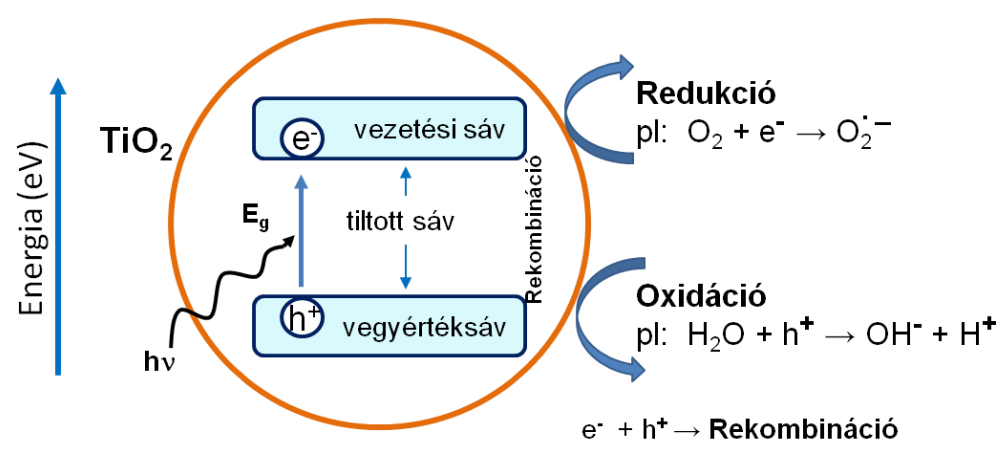

8. ábra. $\mathrm{A} \mathrm{TiO}_{2}$ fotokatalizátor gerjesztésének sematikus ábrája és a lejátszódó kémiai folyamatok. 
A fotokatalítikus folyamat során reaktív gyökök keletkeznek, mint a szuperoxid- $\left(\mathrm{O}_{2}^{-} \cdot\right)$, hidrogén-peroxid- $\left(\mathrm{H}_{2} \mathrm{O}_{2}\right)$, vagy hidroxil- gyök $(\cdot \mathrm{OH})$ [85], melyek megfelelően nagy oxidációs potenciállal rendelkeznek, így különböző szerves anyagokat képesek fotodegradálni [86, 87]. Ezen tulajdonságokat kihasználva, a fotokatalizátor részecskék alkalmasak szennyező anyagok lebontására [88], ill. akár a felületen adszorbeálódott mikroorganizmusok eliminálására, vagyis a felületek mikrobiális fertőtlenítésére is [89]. 


\section{Kísérleti körülmények és vizsgálati módszerek}

\subsection{A kísérletek során felhasznált anyagok}

2:1 Mg/Al-LDH előállításához felhasznált anyagok:

- Magnézium-nitrát 6-hidrát $\left(\mathrm{Mg}\left(\mathrm{NO}_{3}\right)_{2} \bullet 6 \mathrm{H}_{2} \mathrm{O}\right), 99 \%$, Fluka Chemika

- Alumínium-nitrát 9-hidrát $\left(\mathrm{Al}\left(\mathrm{NO}_{3}\right)_{2} \bullet 9 \mathrm{H}_{2} \mathrm{O}\right)$, Molar Chemicals Kft.

- Nátrium-hidroxid ( $\mathrm{NaOH})$, Molar Chemicals Kft.

- Nitrogén gáz, 99,999 \%-os tisztaságú, Messer

- ioncserélt víz, ill. kiforralt és $\mathrm{N}_{2}$-el átbuborékoltatott ioncserélt víz

ZnMgAl-LDH előállításához felhasznált anyagok:

- Cink-nitrát 6-hidrát $\left(\mathrm{Zn}\left(\mathrm{NO}_{3}\right)_{2} \bullet 6 \mathrm{H}_{2} \mathrm{O}\right), 99 \%$, Fluka Chemicals

- Magnézium-nitrát 6-hidrát $\left(\mathrm{Mg}\left(\mathrm{NO}_{3}\right)_{2} \bullet 6 \mathrm{H}_{2} \mathrm{O}\right), 90 \%$, Fluka Chemicals

- Alumínium-nitrát 9-hidrát $\left(\mathrm{Al}\left(\mathrm{NO}_{3}\right)_{2} \bullet 9 \mathrm{H}_{2} \mathrm{O}\right)$, Molar Chemicals Kft.

- Nátrium-hidroxid ( $\mathrm{NaOH})$, Molar Chemicals Kft.

- $\operatorname{Karbamid}\left(\mathrm{CO}\left(\mathrm{NH}_{2}\right)_{2}\right), 98 \%$, Sigma-Aldrich

- ioncserélt víz és kiforralt, $\mathrm{N}_{2}$-el átbuborékoltatott ioncserélt víz

- Nitrogén gáz, 99,999 \%-os tisztaságú, Messer

Hidroxiapatit (HAp) előállításához felhasznált anyagok:

- Kálcium-nitrát-tetrahidrát $\left(\mathrm{Ca}\left(\mathrm{NO}_{3}\right)_{2} \bullet 4 \mathrm{H}_{2} \mathrm{O}\right)$, purum, Reanal

- di-Ammónium-hidrogén-foszfát $\left(\left(\mathrm{NH}_{4}\right)_{2} \mathrm{HPO}_{4}\right), 98 \%$, AlfaAesar GmbH\&Co. KG.

- Ammónia-oldat $\left(\mathrm{NH}_{4} \mathrm{OH}\right) 25 \%$-os, Molar Chemicals Kft.

- ioncserélt víz

Kinurénsav/ LDH nanokompozit előállításához felhasznált anyagok:

- $\quad$ szintetizált 2:1 Mg/Al-LDH

- Kinurénsav, $98 \%$, Sigma-Aldrich

- ioncserélt víz

$\mathrm{LDH} / \mathrm{Ag}^{0}$-montmorillonit kompozitok előállításához felhasznált anyagok:

- $\quad$ szintetizált ZnMgAl-LDH

- Nátrium-montmorillonit EXM-838 $\left(\mathrm{Na}_{2} \mathrm{Al}_{2} \mathrm{O}_{6} \mathrm{Si}\right), \mathrm{d}<2 \mu \mathrm{m}$, Süd-Chemie AG, Németország 
- Ezüst-nitrát $\left(\mathrm{AgNO}_{3}\right), 99,9 \%$, Molar Chemicals Kft.

- Nátrium-borhidrid $\left(\mathrm{NaBH}_{4}\right), 99 \%$, Sigma-Aldrich

- ioncserélt víz

LDO/ polimer kompozitok előállításához felhasznált anyagok:

- $\quad$ szintetizált ZnMgAl-LDH

- $1 \mathrm{H}, 1 \mathrm{H}, 2 \mathrm{H}, 2 \mathrm{H}$-perfluor-decil-akrilát, (PFDAk) monomer, $97 \%$ Aldrich Chemicals

- 2,2-dimetoxi-2-fenil-acetofenont (Irgacure 651) fotoiniciátor, $99 \%$ Aldrich Chemicals

- n-butil-acetát $\left(\mathrm{C}_{6} \mathrm{H}_{12} \mathrm{O}_{2}\right), 99,42 \%$, Molar Chemicals Kft.

$\mathrm{TiO}_{2} /$ HAp kompozitok és kompozit filmek előállításához felhasznált anyagok:

- Titán-dioxid P25 ( $\mathrm{TiO}_{2}$ P25), 100 \%, Evonik Degussa International AG

- Kálcium-nitrát-tetrahidrát $\left(\mathrm{Ca}\left(\mathrm{NO}_{3}\right)_{2} \bullet 4 \mathrm{H}_{2} \mathrm{O}\right)$, purum, Reanal

- di-Ammónium-hidrogén-foszfát $\left(\left(\mathrm{NH}_{4}\right)_{2} \mathrm{HPO}_{4}\right), 98 \%$, AlfaAesar GmbH\&Co. KG.

- Ammónia-oldat $\left(\mathrm{NH}_{4} \mathrm{OH}\right) 25 \%$-os, Molar Chemicals Kft.

- poli-akrilát polimer (poli(etil-akrilát-ko-metil-metakrilát, p(EA-co-MMA), Pannoncolor Kft., $51 \%$-os vizes latex diszperzió

- ioncserélt víz

\subsection{Szintézismódszerek}

\subsubsection{2:1 Mg/Al-LDH előállítása}

2:1 Mg/Al-LDH minta előállítása során 25,64 g Mg( $\left.\mathrm{NO}_{3}\right)_{2} \cdot 6 \mathrm{H}_{2} \mathrm{O}$-t és $18,76 \mathrm{~g} \mathrm{Al}\left(\mathrm{NO}_{3}\right)_{3} \cdot 9 \mathrm{H}_{2} \mathrm{O}-$ t $300 \mathrm{~mL} \mathrm{~N}$-gázzál átbuborékoltatott, kiforralt ioncserélt vízben oldottam fel, majd az oldathoz annyi 1,875 M-os $\mathrm{NaOH}$-oldatot ( $\mathrm{N}_{2}$-gázzál átbuborékoltatott kiforralt ioncserélt vízben feloldva) adtam, hogy a keletkezett szuszpenzió $\mathrm{pH}$-ja elérje a $\mathrm{pH}=3$ értéket. Az előállított $500 \mathrm{~mL}$ szuszpenziót 17 órán keresztül kevertettem $\mathrm{N}_{2}$ gáz alatt $80^{\circ} \mathrm{C}$-on, majd ezt követően 3 napig öregítettem. A kapott szuszpenziót szintén kiforralt és $\mathrm{N}_{2}$ gázzal átbuborékoltatott ioncserélt vízzel háromszor átmostam, majd meghatároztam az előállított LDH tömegkoncentrációját, mely a gravimetriás mérések alapján 4,14 m/m\%-nak adódott. A kapott kitermelés: 46,62 \%. 


\subsubsection{ZnMgAl-LDH előállítása}

\subsubsection{ZnMgAl-LDH elöállitása különbözö pH értéken}

A szintézis során megvizsgáltam a pH szerepének hatását az előállított LDH minták morfológiai tulajdonságaira. A szintézisek során olyan $2 \%$-os szuszpenzió mintákat állítottam elö, ahol a pH értékek rendre $\mathrm{pH}=3 ; 5 ; 8 ; 10$ és 12 - re voltak beállítva $0,01-0,1 \mathrm{M}$-os $\mathrm{NaOH}$-, ill. $\mathrm{HNO}_{3}$-oldatok hozzáadása mellett. A szintéziseket mind karbonátos (ioncserélt víz), mind karbonát mentes $\left(\mathrm{N}_{2}-\right.$ gázzál átbuborékoltatott, kiforralt ioncserélt víz) közegben elvégeztem. A pH mérés során a Metrohm, 827 pH lab nevü készüléket használtam.

A ZnMgAl-LDH előállítása során a $(\mathrm{Zn}+\mathrm{Mg}):$ Al molaránya $2: 1$; még a $\mathrm{Zn}: \mathrm{Mg}=1: 8$ volt [37]. Ennek megfelelően az alábbi tömegeket mértem ki: 0,338 g Zn( $\left(\mathrm{NO}_{3}\right)_{2} \bullet 6 \mathrm{H}_{2} \mathrm{O}-\mathrm{t}, 2,328 \mathrm{~g}$ $\mathrm{Mg}\left(\mathrm{NO}_{3}\right)_{2} \bullet 6 \mathrm{H}_{2} \mathrm{O}$-t, $1,916 \mathrm{~g} \mathrm{Al}\left(\mathrm{NO}_{3}\right)_{3} \bullet 9 \mathrm{H}_{2} \mathrm{O}$-t és 2,102 $\mathrm{g}$ karbamidot $\left(\mathrm{CO}\left(\mathrm{NH}_{2}\right)_{2}\right)$, majd $30 \mathrm{~mL}$ ioncserélt vízben oldottam fel a Zn-, Mg- és Al- kristályvizes sókat, szobahőmérsékleten, levegő atmoszféra alatt. Ezt követően a $10 \mathrm{~mL}$ ioncserélt vízben feloldott (szobahőmérsékleten, levegö atmoszféra alatt) karbamid oldatot kis részletekben hozzácsepegtettem a $30 \mathrm{~mL}$ só-oldathoz, folyamatos kevertetés közben. Az így összeállított oldathoz $10 \mathrm{M}$-os NaOH-oldatot adagoltam, kis részletekben, a kívánt $\mathrm{pH}$ értékek eléréséhez. Minden $\mathrm{pH}$ tartománynál $(\mathrm{pH}=3 ; 5 ; 8 ; 10$ és 12) $5 \mathrm{~mL}$ térfogatú mintát vettem és 72 órán keresztül (3 napig) kevertettem 990 rpm-es fordulatszámon, szobahőmérsékleten. Az előállított mintákat 25 órán keresztül szárítószekrényben inkubáltam, közel $100{ }^{\circ} \mathrm{C}$-on, és $60{ }^{\circ} \mathrm{C}$-on szárítószekrényben szárítottam (egy éjszakán keresztül). Végül a beszáradt mintákat mostam és porítottam.

\subsubsection{Az öregitési idő hatása a ZnMgAl-LDH szintézise során, $p H=3$-as értéken}

Az előző pontban (3.2.2.1.), a pH= 3-as értéken előállított LDH biztató eredményeket mutatott, a gömbi morfológia kialakulása szempontjából, ezért a további lépésekben, a kívánt struktúra eléréséhez, a szintéziseket $\mathrm{pH}=3$ értéken hajtottam végre. Az előállítás során figyelemmel kísértem az öregítési idő szerepét, ezért a szintéziseket 24, 48 és 1 hetes öregítési idő követte $98^{\circ} \mathrm{C}$-on. A ZnMgAl-LDH előállításakor a prekurzorok ötszörös bemérési mennyiségével dolgoztam. Az előző pontban (3.2.2.1.) ismertetett mennyiségekhez képest a $\mathrm{Zn}\left(\mathrm{NO}_{3}\right)_{2} \bullet 6 \mathrm{H}_{2} \mathrm{O}$-ból 1, 69 g-ot, a $\mathrm{Mg}\left(\mathrm{NO}_{3}\right)_{2}$ - $6 \mathrm{H}_{2} \mathrm{O}$-ból 11,64 g-ot, az Al( $\left(\mathrm{NO}_{3}\right)_{3} \bullet 9 \mathrm{H}_{2} \mathrm{O}$-ból pedig 9,58 g-ot oldottam 200 mL ioncserélt vízben. A $10,51 \mathrm{~g}$ karbamidot pedig $50 \mathrm{~mL}$ ioncserélt vízben oldottam, majd kis részletekben hozzácsepegtettem a 200 mL só-oldathoz, folyamatos kevertetés közben. A kapott szuszpenziókat 990 rpm-es fordulatszámon centrifugáltam, majd kétszer mostam 50-50 mL ioncserélt vízzel és ismételt centrifugálást követően $60^{\circ} \mathrm{C}$-on szárítószekrényben szárítottam (egy éjszakán keresztül). 


\subsubsection{ZnMgAl-LDO előállítása}

A 3.2.2.2. fejezetben leírt módon elöállított $\mathrm{ZnMgAl}-\mathrm{LDH}$ por mintát (1 hetes öregítési idöt alkalmazva) $600{ }^{\circ} \mathrm{C}$-on 2 órán keresztül porcelán tégelyben kalcináltam.

\subsubsection{Felületi ezüst nanorészecskéket tartalmazó montmorillonit szintézise}

A rétegközi ezüst nanorészecskéket tartalmazó montmorillonit ( $\mathrm{Ag}^{0}$-montmorillonit) szintézise során a kiindulási Na-montmorillonitból 2 (m/V)\%-os szuszpenziót készítettem, 30 g száraz anyagot bemérve 1,5 liter ioncserélt vízbe. Az így kapott szuszpenzióhoz két napos $35^{\circ} \mathrm{C}$-on történő duzzasztás után a montmorillonit kationcsere kapacitásának (CEC: 100 mekv/ 100g) megfelelő fele mennyiségü 2,5507 g $\mathrm{AgNO}_{3}$-ot adtam. A szuszpenziót újabb két napig termosztáltam $35^{\circ} \mathrm{C}$ on sötét körülmények között, hogy az ioncsere egyensúly beálljon. Ezt követően a szuszpenziót lecentrifugáltam (40 percen keresztül 11.000 rpm fordulatszámon), a felülúszót eltávolítottam, majd az üledéket ismételten 1 liter ioncserélt vízben visszaszuszpendáltam. Az ezüst nanorészecskéket kémiai redukciós módszerrel állítottam elő, redukálószerként $\mathrm{NaBH}_{4}$-et használtam. Számított mennyiségü (2,55 g/100 mL) $\mathrm{NaBH}_{4}$-et tartalmazó oldatot csepegtettem a szuszpenzióhoz. Az így kapott $\mathrm{Ag}^{0}$-montmorillonit szuszpenziót centrifugálást követően (40 percen keresztül $11.000 \mathrm{rpm}$ fordulatszámon) liofilizáltam.

\subsubsection{Hidroxiapatit (HAp) előállítása}

A HAp csapadékképzéssel történő elöállítása során 14,76 g Ca( $\left.\mathrm{NO}_{3}\right)_{2} \cdot 4 \mathrm{H}_{2} \mathrm{O}$-et $110 \mathrm{~mL}$ ioncserélt vízben oldottam fel, folyamatos kevertetés mellett, majd az oldathoz $20 \mathrm{~mL}$ ammóniaoldatot $\left(25 \mathrm{~m} / \mathrm{m} \%\right.$-os $\left.\mathrm{NH}_{4} \mathrm{OH}\right)$ adtam, hogy az oldat $\mathrm{pH}$-ja elérje a $\mathrm{pH}=11,0$ értéket. Ezzel párhuzamosan 4,95 $\mathrm{g}\left(\mathrm{NH}_{4}\right)_{2} \mathrm{HPO}_{4}$-ot oldottam $50 \mathrm{~mL}$ ioncserélt vízben, melyhez szintén $60 \mathrm{~mL}$ ammónia-oldatot adagoltam $\left(25 \mathrm{~m} / \mathrm{m} \%\right.$-os $\left.\mathrm{NH}_{4} \mathrm{OH}\right)$, a pH= 11,0 érték eléréséhez. A foszfát tartalmú oldathoz, folyamatos csepegtetés mellett, hozzáadtam a $130 \mathrm{~mL}$ 0,48 M-os kálcium-nitrát oldatot. A kívánt $\mathrm{pH}=11,0$ érték beállítása érdekében $10 \mathrm{~mL}$ ammónia-oldatot adtam, így a végső térfogat $250 \mathrm{~mL}$ és szintézis során a Ca/P mólaránya pedig 1,67 volt [90].

A HAp szintézise szobahőmérsékleten, 24 órán keresztül játszódott le. A folyamat végén, a kapott csapadékot szüréssel választottam le, majd ioncserélt vízzel mostam, az ammónium-nitrát eltávolításának céljából. A kapott fehér csapadékot $100{ }^{\circ} \mathrm{C}$-on szárítószekrényben egy éjszakán keresztül szárítottam. 


\subsubsection{Poli-perfluorodecil-akrilát, $\mathrm{p}(\mathrm{PFDAk})$ előállítása}

A fotokatalizátor részecskék felületi rögzítéséhez fluoropolimer alapú makromolekulás kötőanyagot is alkalmaztam. Ennek szintéziséhez az $1 \mathrm{H}, 1 \mathrm{H}, 2 \mathrm{H}, 2 \mathrm{H}$-perfluor-decil-akrilát (PFDAk) monomert használtam. A monomert és a fotoiniciátort (2,2-dimetoxi-2-fenil-acetofenont (Irgacure 651) további tisztítás nélkül használtam fel. A fluorpolimert UV-polimerizációs módszerrel állítottam elő, úgy hogy a szintézis során $0,1 \mathrm{~m} / \mathrm{m} \%$ fotoiniciátort adtam a kiindulási folyékony monomerhez. Ezt követően 10 percig nitrogéngázzal buborékoltattam az elegyet, hogy eltávolítsam az oldott oxigént, amely a reakció gátlója. Az elegyet 30 percig UV-fény bevilágításnak tettem ki (alkalmazott fényforrás: Q81 típusú lámpa, Heraeus Gmbh; teljesítmény: $70 \mathrm{~W} ; \lambda_{\max }=265$ nm). A polimerizációs eljárás után a kapott poli $(1 \mathrm{H}, 1 \mathrm{H}, 2 \mathrm{H}, 2 \mathrm{H}$-perfluor-decil-akrilát) (p(PFDAk)) fluoropolimer mintát toluolban oldottam és egy $35 \mathrm{~m} / \mathrm{m} \%$ polimer-oldatot készítettem a további alklamazásokhoz.

\subsubsection{Kinurénsav/ LDH interkalációs nanokompozit előállítása}

A kinurénsav/ LDH nanokompozitot ioncserén alapuló interkalációs reakció kivitelezésével állítottam elő. A folyamat során a 3.2.1. pontban előállított 4,14 m/m \%-os 2:1 Mg/Al-LDHszuszpenzióból indultam ki $(\mathrm{pH}=11,17)$. Meghatározva az LDH aniononcsere kapacitását $(0,641$ mmol/g), az interkalálni kívánt kinurénsav (KYNA) mennyiségét $30 \mathrm{~m} / \mathrm{m} \%$-ban állapítottam meg az LDH tömegére vonatkoztatva, mely egyébként a meghatározott ioncsere kapacitás 2,46-szorosa volt. Így a KYNA/ LDH arány: $300 \mathrm{mg} / \mathrm{g}$ volt. Az így kapott szuszpenziót (pH 10 értéken), 48 órán keresztül kevertettem szobahőmérsékleten $\left(25^{\circ} \mathrm{C}\right.$-on), majd ioncserélt vízzel történő mosását követően (eltávolítva a felesleges KYNA mennyiséget), szobahőmérsékleten bepároltam további vizsgálatok céljából.

\subsection{8 $\mathrm{LDH} / \mathrm{Ag}^{0}$-montmorillonit heterokoagulációs kompozit előállítása}

$\mathrm{Az} \mathrm{LDH} / \mathrm{Ag}^{0}$-montmorillonit pH-függő szol-gél rendszer előállítása során $0,1 \mathrm{~g}$ gömb alakú ZnMgAl-LDH por mintát (lásd a 3.2.2.2. fejezetben szintetizált, 1 hetes öregítési időt alkalmazva), $10 \mathrm{~mL} 3 \mathrm{~m} / \mathrm{m} \%$-os $\mathrm{Ag}^{0}$-montmorillonit szuszpenzióban diszpergáltam, folyamatos kevertetés mellett. Az LDH és az $\mathrm{Ag}^{0}$-montmorillonit aránya $25 / 75 \mathrm{~m} / \mathrm{m} \%$ volt a $4 \%$-os szuszpenzióban. A szuszpenzió $\mathrm{pH}$-ját $\mathrm{pH}=2 ; 3 ; 4,5$ és 6-os értékekre állítottam be $0,50-0,01 \mathrm{M}$-os $\mathrm{HNO}_{3}$-oldat adagolásával. A pH mérés során a Metrohm, 827 pH lab nevü készüléket használtam. 


\subsubsection{LDO/ p(PFDAk) fluoropolimer rétegek kialakítása}

A 3.2.3. fejezetben előállított hidrofil tulajdonságú LDO részecskéket felhasználva LDO/ fluoropolimer kompozit rétegeket alakítottam ki, $5 \times 5 \mathrm{~cm}^{2}$-es üveglapok felszínén, porlasztva szárítással (ún. spray-coating technikával). Első lépésben 10-10 mL, 2 m/m\%-os diszperziókat készítettem. A diszperziókban az LDO/ fluoropolimer tömegaránya a következő összetétel szerint változott: 0/100, 10/90, 20/80, 30/70, 40/60, 50/50, 60/40, 70/30, 80/20, 90/10 és 100/0 m/m\% LDO/ p(PFDAk). Ennek megfelelően a kiindulási $35 \mathrm{~m} / \mathrm{m} \%$-os p(PFDAk) fluoropolimer-oldat butil-acetát oldószerrel történő hígítását követően, a 10-10 mL polimer-oldatokhoz rendre 0,$02 ; 0,04 ; 0,06 ; 0,08$; 0,$10 ; 0,12 ; 0,14 ; 0,16 ; 0,18$ és 0,20 g LDO-t adtam, növelve a kompozit rétegek LDO részecske tartalmát. Az összeállított 10-10 mL, $2 \mathrm{~m} / \mathrm{m} \%$-os LDO/ fluoropolimer diszperziókat, 5 perces ultrahangos kezelést követően, $15 \mathrm{~cm}$-es távolságból $25 \mathrm{~cm}^{2}$-es üveghordozóra juttattam, egy R180 típusú Airbrush pisztoly segítségével, 3 bar nitrogén gáz nyomása alkalmazása mellett. A kialakított vékonyrétegek fajlagos tömege $5,8 \pm 0,11 \mathrm{mg} / \mathrm{cm}^{2}$ volt.

\subsubsection{0 $\mathrm{TiO}_{2} / \mathrm{HAp}$ kompozitok előállítása}

A kompozitok előállítása során a HAp csapadékképzéssel történő előállítása (lásd 3.2.5. fejezet) P25 $\mathrm{TiO}_{2}$ nanorészecskék jelenlétében valósult meg. A $\mathrm{TiO}_{2} / \mathrm{HAp}$ szintézise során 8,855 g $\mathrm{Ca}\left(\mathrm{NO}_{3}\right)_{2} \cdot 4 \mathrm{H}_{2} \mathrm{O}-\mathrm{t} 19 \mathrm{~mL}$ ioncserélt vízben oldottam fel folyamatos kevertetés mellett, majd az oldathoz $15 \mathrm{~mL}$ ammónia-oldat $\left(25 \mathrm{~m} / \mathrm{m} \%\right.$-os $\mathrm{NH}_{4} \mathrm{OH}$ ) hozzáadásával az oldat pH-ját pH=11,0-re állítottam. Ezt követően rendre 0; 0,943; 2,512; 5,651 és 15,068 g P25 TiO 2 -ot adtam a kálciumnitrát-oldatokhoz folyamatos kevertetés mellett, kialakítva a kívánt $\mathrm{TiO}_{2} / \mathrm{HAp}$ arányt, mely a $\mathrm{TiO}_{2}-$ ra nézve 0, 20, 40, 60 és $80 \mathrm{~m} / \mathrm{m} \%$ volt. Ezután 2,97-2,97 g $\left(\mathrm{NH}_{4}\right)_{2} \mathrm{HPO}_{4}$-ot 8-8 mL ioncserélt vízben oldottam és kis részletekben a $\mathrm{TiO}_{2}$ tartalmú kálcium-nitrát diszperziókhoz csepegtettem. Végül 8$8 \mathrm{~mL}$ ammónia-oldatot adtam $\left(25 \mathrm{~m} / \mathrm{m} \%\right.$-os $\left.\mathrm{NH}_{4} \mathrm{OH}\right)$ a $\mathrm{TiO}_{2}$ tartalmú diszperzókhoz, a $\mathrm{pH}=11,0$ érték elérésnek céljából. A kialakított $\mathrm{TiO}_{2} / \mathrm{HAp}$ rendszerek végső térfogat 50-50 mL és a szintézis során a $\mathrm{Ca} / \mathrm{P}$ mólaránya pedig 1,67 volt. A diszperziókat 24 órán keresztül $60{ }^{\circ} \mathrm{C}$-on kevertettem, majd a csapadékot szüréssel választottam le, ioncserélt vízzel mostam, az ammónium-nitrát eltávolításának céljából. Végül a kapott fehér csapadékot $100{ }^{\circ} \mathrm{C}$-on szárítószekrényben egy éjszakán keresztül szárítottam. Összehasonlítás céljából $\mathrm{TiO}_{2} / \mathrm{HAp}$ fizikai keverék mintasorozatot is készítettem, ahol a $\mathrm{TiO}_{2}$ szintén $0,20,40,60$ és $80 \mathrm{~m} / \mathrm{m} \%$-ban volt jelen a keverékben. $\mathrm{A} \mathrm{TiO}_{2} /$ HAp fizikai keverék pormintákat 50-50 mL ioncserélt vízben diszpergáltam és 24 órán keresztül 60 ${ }^{\circ} \mathrm{C}$-on kevertettem. A diszperziókat centrifugáltam $(10$ percen keresztül $13.000 \mathrm{rpm}$ fordulatszámon), majd szárítószekrényben $100^{\circ} \mathrm{C}$-on, egy éjszakán keresztül szárítottam. 


\subsubsection{1 $\mathrm{TiO}_{2} / \mathrm{HAp} / \mathrm{p}(\mathrm{EA}-c o-M M A)$ polimer kompozitok kialakítása}

A 3.2.10. fejezetben előállított $\mathrm{TiO}_{2} / \mathrm{HAp}$ mintákat felhasználva, $\mathrm{TiO}_{2} / \mathrm{HAp} / \mathrm{p}(\mathrm{EA}-c o-M M A)$ polimer vékonyrétegeket készítettem porlasztva szárításos filmképzéses eljárással $5 \times 10 \mathrm{~cm}^{2}$-es üveglapok felszínén. A kompozit rétegek kialakítása során hidrofil tulajdonságú poli-akrilát polimert (poli(etil-akrilát-ko-metil-metakrilát, p(EA-co-MMA)) alkalmaztam. A polimer kötőanyag a kompozitban minden esetben $40 \mathrm{~m} / \mathrm{m} \%$-ban volt jelen a $60 \mathrm{~m} / \mathrm{m} \%$-nyi $\mathrm{TiO}_{2} / \mathrm{HAp}_{\text {töltöanyag }}$ keverék mellett úgy, hogy ezen belül a $\mathrm{TiO}_{2}$ és HAp komponensek tömegaránya $20 \%$-onként változott, azaz a teljes filmre vonatkoztatva rendre $0 / 60,12 / 48,24 / 36,36 / 24,48 / 12$ és 60/0 m/m\% volt.

A vékonyrétegekből két sorozatot készítettem, az egyikben a 3.2.10. fejezetben bemutatott $\mathrm{TiO}_{2} /$ HAp kompozitot, míg a másik sorozatban a $\mathrm{TiO}_{2} / \mathrm{HAp}$ fizikai porkeveréket alkalmaztam. A rétegek kialakítása során 10-10 mL, $2 \mathrm{~m} / \mathrm{m} \%$-os $\mathrm{TiO}_{2} / \mathrm{HAp} / \mathrm{p}$ (EA-co-MMA) vizes diszperziókat készítettem, majd 5 perces ultrahangos kezelést követően, $15 \mathrm{~cm}$-es távolságból, az R180 típusú Airbrush pisztoly segítségével, az $50 \mathrm{~cm}^{2}$-es üveghordozóra porlasztottam a mintákat. A kialakított vékonyrétegek fajlagos tömege pedig $1,02 \pm 0,12 \mathrm{mg} / \mathrm{cm}^{2}$ volt.

\subsection{Vizsgálati módszerek}

\subsubsection{Diffrakciós szerkezetvizsgálati módszerek}

\section{Röntgendiffrakció (XRD)}

Az elöállított komponensek valamint a kialakított kompozitok szerkezeti jellemzéséhez röntgendiffrakciós méréseket alkalmaztam. A porminták méréseit egy Bruker D8 röntgendiffraktométerrel végeztük ( $\mathrm{CuK}_{\alpha}$ sugárzás: $\left.\lambda=0,154 \mathrm{~nm}, 40-50 \mathrm{kV}, 30-40 \mathrm{~mA}\right), 2-60^{\circ}$

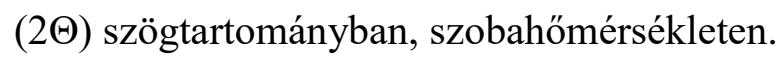

A bázislap-távolságok meghatározására a Bragg-egyenletet (3. egyenlet) használtam:

$$
\lambda=2 d \cdot \sin \Theta
$$

ahol $\lambda$ a röntgensugár hullámhossza, $d$ a bázislapok közötti távolság, és $\Theta$ pedig a diffrakciós szög.

Bizonyos minták esetében a kapott diffraktogramokból a Scherrer-egyenlet (4. egyenlet) felhasználásával meghatároztam a krisztallitok méretét: 


$$
d=\frac{K \cdot \lambda}{\beta \cdot \cos \Theta}
$$

ahol $d$ az átlagos krisztallitméret, $K$ egy alakfüggő konstans $(0,89), \lambda$ a röntgensugárzás hullámhossza, $\beta$ a reflexiós csúcs félérték-szélessége radiánban megadva és $\Theta$ pedig a Bragg-szög értéke.

\section{Kisszögü röntgenszórás (SAXS)}

A gömbi LDH, $\mathrm{Ag}^{0}$-montmorillonit, $\mathrm{LDH} / \mathrm{Ag}^{0}$-montmorillonit $(25 / 75 \mathrm{~m} / \mathrm{m} \%)$ és a $\mathrm{TiO}_{2} / \mathrm{HAp}$ $(=0 / 100,20 / 80,40 / 60,60 / 40,80 / 20$ és $100 / 0 \mathrm{~m} / \mathrm{m} \%)$ mintákat kisszögü röntgenszórási vizsgálatokkal is jellemeztük. A módszer a kolloid mérettartományú (1-100 nm) inhomogenitásokkal leírható rendszerek szerkezetének jellemzésére szolgál. A SAXS mérések információt szolgáltatnak a részecskék méretéről, alakjáról, aggregációs állapotáról, a diszperz rendszer fajlagos felületéről, porozitásáról is.

A röntgen pordiffrakciós technikától eltérően itt a kis szögek tartományában $\left(0,05 \geq 2 \Theta^{\circ} \leq 5\right)$ fellépő röntgenszórást detektáljuk. A szög függvényében detektált intenzitás a szórásgörbe. A számításokban a szórási szög helyett a szórásvektort használjuk.

A szórt sugárzás $I$ intenzitása a szórásszög $(2 \Theta)$, ill. a szórásvektor $(h=(4 \pi / \lambda) \sin (\Theta))$ függvénye

\section{(5. egyenlet).}

$$
I(h)=\eta^{2}(0) V \int_{0}^{\infty} 4 \pi r^{2} \gamma_{0}(r) \frac{\sin h r}{h r} d r
$$

ahol $V$ a rendszer térfogata, amelyben az elektronokon a röntgensugarak szóródása történik, $\gamma_{0}(r)$ a korrelációs függvény. A fenti egyenletben $\eta^{2}(0)$ függvény értéke a következők szerint definiálható (6. egyenlet):

$$
\eta^{2}(0)=\frac{1}{V} \int_{0}^{\infty}\left(\rho_{e}(r)-\rho_{e}\right)^{2} d^{3} r
$$

ahol $\rho_{e}(r)$ az elektronsürüség-eloszlási függvény adott $r$ távolságban, ill. $\rho_{e}$ az átlagos érték.

A szórásfüggvényből pedig az $I(h) h^{3}$ vs. $h^{3}$ reprezentációból számítható a következő egyenlet szerint:

$$
K_{P}=\lim _{h \rightarrow \infty} I(h) h^{3}
$$


ahol $K_{p}$ a Porod-konstans.

A részecskék fajlagos felülete ( $V$ térfogat egységre vonatkoztatva) és a fajlagos felület nagysága megadható a 8. és 9. egyenlettel:

$$
\begin{aligned}
& S / V=4 w_{1} w_{2} K_{P} / Q \\
& a^{s}=\left(S / V \cdot 10^{3}\right) / d
\end{aligned}
$$

ahol $K_{p}$ a Porod-konstans, $w_{1}$ és $w_{2}$ a szilárd (1) és fluid (2) fázis térfogati törtje, $Q$ az invariáns, $d$ a diszperz rendszer sürüsége $\mathrm{g} / \mathrm{cm}^{3}$-ben megadva.

A szórásgörbék egy Philips PW 1820 típusú röntgencsővel (CuK $\alpha$ sugár, $\lambda=0,154$ nm, 40 kV, 30 mA) szerelt KCEC/3 (Anton Paar KG, Graz, Ausztria) típusú kompakt Kratky-kamerával kerültek rögzítésre 2 mm átmérőjű kapilláris mintatartókban. A szórt sugárzás intenzitását egy PDS 50M (M. Braun AG, München) típusú helyérzékeny detektorral rögzítettük $\mathrm{h}=0,1-5 \mathrm{~nm}^{-1}$ szórásvektor tartományban. A kapott szórásfüggvényből a háttér szórását kivonva alkalmas a módszer szerkezeti paraméterek számítására. A számításokhoz ATSAS Gnom szoftvert használtunk.

\subsubsection{Infravörös spektroszkópia (FT-IR)}

Az infravörös spektroszkópiás mérés során elektromágneses sugárzás hatására a molekulák rezgési és forgási átmenetei gerjesztődnek, eközben a minta a rezgéseire jellemző frekvenciájú komponenseket elnyeli, lehetővé téve a különböző anyagok azonosítását, funkciós csoportok kimutatását, valamint kötések létrejöttének a bizonyítását. A mérések FT-IR PAS (fotoakusztikus spektroszkópia) módban történtek (Biorad FTS-60A FT-IR spektrométer, $4 \mathrm{~cm}^{-1}$ digitális felbontásban, 4000- $400 \mathrm{~cm}^{-1}$ tartományon). A minták színképei a GRAMS/AI nevű programmal lettek átalakítva a további értékeléshez. A 2:1 Mg/Al-LDH-ba interkalált KYNA hatóanyag esetén végeztünk infravörös spektroszkópiai méréseket alátámasztva az interkaláció sikerességét.

\subsubsection{A minták fajlagos felületi töltésének meghatározása}

A méréstechnika a mintában lévő részecskék töltéselőjelének megállapítására, valamint a töltés fajlagos értékének meghatározására alkalmas [91]. A módszer jellegéből adódóan a mérés során az ekvivalencia pontig ( $0 \mathrm{mV}$ áramlási potenciál) fogyott ellentétes töltésü tenzid-oldat koncentrációja alapján a vizsgált rendszer fajlagos töltése számítható. 
A vizes szuszpenziókban lévő részecskék töltés-, illetve áramlási potenciáljának meghatározása Mütek PCD 02-es töltés meghatározó készülékkel történt (9. (a) ábra). A hengeres teflonedényben a teflon-oszlop periodikus mozgása révén a részecskék körüli elektromos kettősréteg nyírásából potenciálkülönbség mérhető a tefloncső falába ágyazott aranyelektródokon (9. (b) ábra).

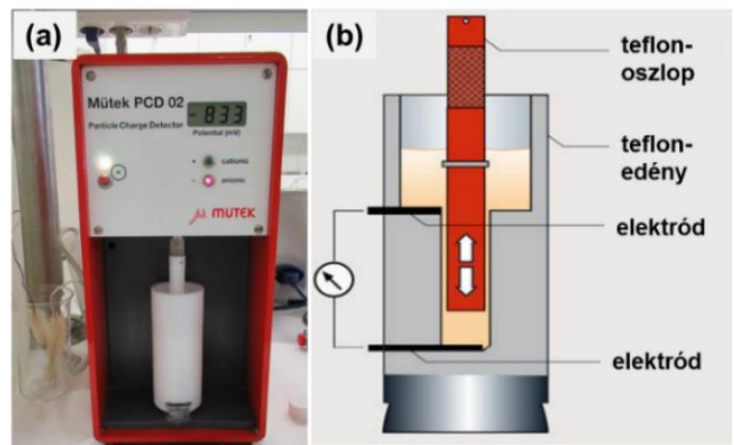

9. ábra. A Mütek PCD 02-es részecske töltés detektor készülék fotója (a) és sematikus (hosszmetszeti) ábrája (b).

A töltéstitrálásos mérésekhez $10 \mathrm{~cm}^{3}$ térfogatú, $0,1 \mathrm{~m} / \mathrm{m} \%$-os 2:1 Mg/Al-LDH (pH= 8,5), ZnMgAl-LDH ( $\mathrm{pH}=2 ; 3$; 4 és 6), ill. montmorillonit ( $\mathrm{pH}=4)$ szuszpenziókat készítettem. A pozitív felületi töltésű LDH minták esetében használt anionos tenzid a nátrium-dodecil-szulfát (NaDS) $\left(\left(\mathrm{C}_{12} \mathrm{H}_{25} \mathrm{NaO}_{4} \mathrm{~S}\right), 98 \%\right.$, Molar Chemicals Kft.) még a negatív felületi töltésü montmorillonit esetében hexadecilpiridinium klorid ( $\mathrm{HDPCl})\left(\left(\mathrm{C}_{21} \mathrm{H}_{38} \mathrm{ClN} \bullet \mathrm{H}_{2} \mathrm{O}\right)\right.$, Molar Chemicals Kft.) volt. Az alkalmazott tenzidkoncentrációk az NaDS esetében 0,1 és $0,001 \mathrm{~m} / \mathrm{m} \%$, míg a montmorillonit esetében $0,1 \mathrm{~m} / \mathrm{m} \%$ volt.

\subsubsection{A fajlagos (BET) felület meghatározása}

A lamellás (2:1 Mg/Al-), gömbi (ZnMgAl-) LDH és LDO minták, valamint a fizikai keverék és csapadékképzéssel előállított $\mathrm{TiO}_{2} / \mathrm{HAp}(0 / 100,20 / 80,40 / 60,60 / 40,80 / 20$ és 100/0 m/m\%) minták fajlagos felületét $\mathrm{N}_{2}$ gázadszorpciós izotermák mérése alapján jellemeztem. A minták előkezelése $100{ }^{\circ} \mathrm{C}$-on, egy éjszakán át, 1,33 mPa nyomáson történt. A mérések a Micrometrics Gemini 2375 típusú automata szorptométerrel készültek $77 \pm 0,5 \mathrm{~K}$ hőmérsékleten, a mért adszorpciós és deszorpciós izotermák kiértékelését program végezte: a BET egyenlet alapján fajlagos felület értékeket kaptunk. 


\subsubsection{Pásztázó elektronmikroszkópia (SEM)}

Néhány kiemelt minta esetén pásztázó elektronmikroszkópos (SEM) mérésekkel vizsgáltam az előállított részecskék méretét és morfológiáját, továbbá a kompozit filmek felületi struktúráját. Ezek a SEM felvételek az SZTE TTIK Elektronmikroszkóp Laboratóriumában, egy Hitachi S-4700 típusú téremissziós pásztázó elektronmikroszkóppal, $5 \mathrm{kV}$ gyorsítófeszültség mellett készültek. Az átlagos részecskeátmérőt és méreteloszlást az ImageJ nevü szoftver segítségével határoztam meg. A baktériumok az LDO/ fluoropolimer rétegeken történő megtapadását is szintén SEM felvételekkel szemléltettem, melyek a “Jožef Stefan” Intézetben, Ljubljanában (Slovéniában) készültek, egy Jeol FEG-SEM 7600F típusú pásztázó elektronmikroszkóppal, $5 \mathrm{kV}$ gyorsítófeszültség alkalmazása mellett.

\subsubsection{Energiadiszperzív röntgenspektroszkópia (EDS)}

$\mathrm{A} \mathrm{TiO}_{2}$ nanorészecskék eloszlását HAp lamellák jelenlétében és annak hiányában, a katalizátor/ polimer tartalmú vékonyrétegekben, energiadiszperzív röntgenspektroszkópiás mérésekkel vizsgáltam. A méréseket a fent említett SZTE TTIK Elektronmikroszkóp Laboratóriumában végeztem, a Hitachi S-4700 Type II pásztázó elektronmikroszkóphoz csatlakoztatott Röntec QX2 detektorral, 20 kV-os gyorsítófeszültség alkalmazása mellett. A mérés során elektron-anyag kölcsönhatás lép fel, melynek során a vizsgált anyagra jellemző röntgensugárzás jön létre és detektálásával információt kaphatunk a minta elemi összetételéről.

\subsubsection{Transzmissziós elektronmikroszkópia (TEM)}

Az elektronmikroszkópos vizsgálatokat a 200 kV-os gyorsítófeszültségü FEI Tecnai G2 20 XTwin típus, CCD kamerával ellátott transzmissziós elektronmikroszkóppal végeztem. TEM felvételeket csak néhány kiválasztott minta esetében készítettem, mint pl. a HAp és $\mathrm{Ag}^{0}$ montmorillonit minták. A kiválasztott mintákból 0,01 m/m\%-os diszperziókat készítettem, majd ezt követően 10-10 $\mu \mathrm{L}$ mintát vékony szénréteggel borított réz mintahordozókra (Carbon Film 200 Mesh Copper grid, ill. Lacey/Carbon Film 200 Mesh Copper grid) cseppentettem. Az ezüstnanorészecskék átlagos részecskeátmérőjét ImageJ nevü szoftver segítségével határoztam meg, min. 40-50 db részecske megszámlálásával az elkészült TEM felvételekről. 


\subsubsection{Diffúz reflexiós spektroszkópia (DRS)}

A diffúz reflexiós méréseket Ocean Optics UV-VIS USB4000 típusú diódasoros spektrofotométerrel hajtottam végre a gömbi LDH, LDO, ZnO (Nanox) és $\mathrm{TiO}_{2} / \mathrm{HAp}(0 / 100,20 / 80$, 40/60, 60/40, 80/20 és 100/0 m/m\% összetételü) porminták esetén. A spektrumokat 200- $850 \mathrm{~nm}$ tartományban rögzítettem. A felületekről reflektálódó fényt optikai szálak segítségével vezettem a spektrofotométerbe (10. ábra).
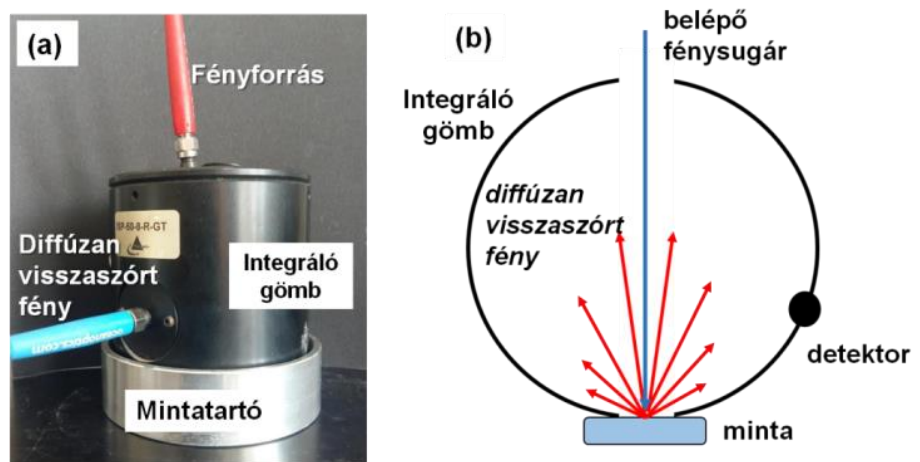

10. ábra. A diffúz-reflexiós mérések során használt integráló gömb fotója (a) és sematikus ábrája (b).

A vizsgált porminták UV-VIS diffúz reflexiós spektrumaiból a minták gerjesztési küszöbenergia értéke $\left(E_{g}(e V)\right)$ határozható meg a Kubelka-Munk függvény segítségével (10. egyenlet) $[92,93]$.

$$
F(R)=\frac{(1-R)^{2}}{2 R}
$$

ahol $R$ a reflexió, az $F(R)$ pedig arányos az abszorpciós koefficienssel $(\alpha)$, mely kifejezhető a következö összefüggéssel (11. egyenlet):

$$
\alpha=\frac{A\left(h v-E_{g}\right)^{n}}{h v}
$$

ahol $A$ konstans, $h v$ a fény energiája és $n$ az elektronátmenet természetétől függő konstans. Így a tiltott sávszélesség értékek meghatározhatók az $[F(R) h v]^{1 / 2}$ (Kubelka-Munk függvény) és a $h v$ függvény ábrázolásából. A $[F(R) h v]^{1 / 2}$ függvény lineáris szakaszán 0-ba történő extrapolációja adja meg a pontos $\mathrm{E}_{\mathrm{g}}$ értéket. A kereskedelmi forgalomban is kapható $\mathrm{ZnO}$ (Nanox, referencia minta) porminta diffúz-reflexiós spektruma és a Kubelka-Munk módszer alapján számított reprezentációja 
a 11. ábrán látható, mely alapján a gerjesztési küszöbenergia $\left(E_{\mathrm{g}}\right)$ érték megadható (11. (b) ábra), mely a $\mathrm{ZnO}$ esetén 3,16 eV-nak adódott. A kapott $\mathrm{E}_{\mathrm{g}}$ érték az irodalmi adatokkal megegyezik [92].
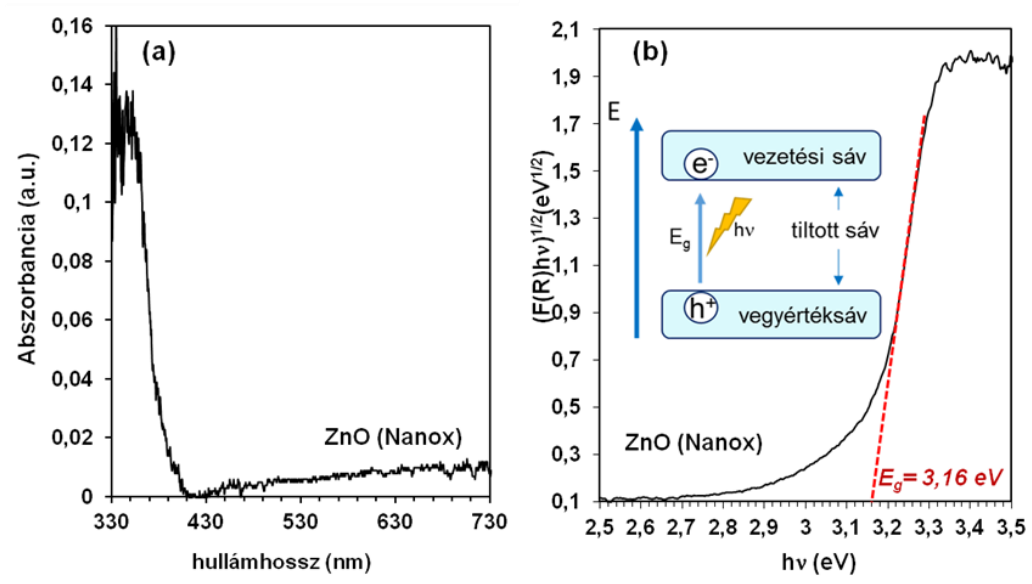

11. ábra. A referencia Nanox $\mathrm{ZnO}$ diffúz-reflexiós spektruma (330-730 nm hullámhossz tartományon) (a) és a diffúz-reflexiós mérésből, Kubelka-Munk módszer alapján számított gerjesztési küszöbenergia $\left(E_{\mathrm{g}}\right)$ érték meghatározása (b).

\subsubsection{Termoanalitikai vizsgálatok (TG)}

A KYNA/ LDH alapú nanohibrid rendszer, valamint az LDO/ p(PFDAk) (0/100, 20/80, 40/60, 60/40, 80/20 és 100/0 m/m\%-os összetételü) minták termogravimetriai analízise egy Mettler-Toledo TGA/SDTA $851^{\mathrm{e}}$ típusú készülékkel történt. Az 5-10 mg mennyiségü mintákat $70 \mu \mathrm{L}$ térfogatú alumínium-oxid tégelybe mértem, melyeket azután szintén $25-1000{ }^{\circ} \mathrm{C}$ hömérséklet tartományban, $5{ }^{\circ} \mathrm{C} /$ perc lineáris fütési sebesség alkalmazása mellett vizsgáltam. A mérési eredmények kiértékelését a Mettler-Toledo $\mathrm{STAR}^{\mathrm{e}}$ v8.10 mérésvezérlő és értékelő számítógépes programmal végeztem.

3.3.10 Reológiai tulajdonságok meghatározása

A reológiai vizsgálatokat egy Anton Paar Physica MCR 301 típusú reométerrel végeztem (12. (a) ábra), egy úgynevezett „double gap” (kétfalú, henger) mérőfej (DG 26.7) alkalmazásával (12. (b) és (c) ábra). A mérés során a müszer a nyírófeszültséget ( $\tau, \mathrm{Pa})$ regisztrálta az egyre növekvő (30-500 s $\left.{ }^{-1}\right)$ deformációs sebesség értékeknél, állandó hőmérsékleten $\left(25^{\circ} \mathrm{C}\right.$-on $)$.

A minták mérésre történő előkészítése során 1, 2 és $3 \mathrm{~m} / \mathrm{m} \%$-os kiindulási montmorillonit és $\mathrm{Ag}^{0}$-montmorillonit szuszpenziókat készítettem. Az így összeállított minták folyásgörbéinek tanulmányozását követően egy összetételnél, azaz $3 \mathrm{~m} / \mathrm{m} \%$-os montmorillonit, $\mathrm{Ag}^{0}$-montmorillonit 
és $\mathrm{LDH} / \mathrm{Ag}^{0}$-montmorillonit $(25 / 75 \mathrm{~m} / \mathrm{m} \%)$ rendszerek folyásgörbéit rögzítettem $\mathrm{pH}=3$; 4,5 és 6os értéken.

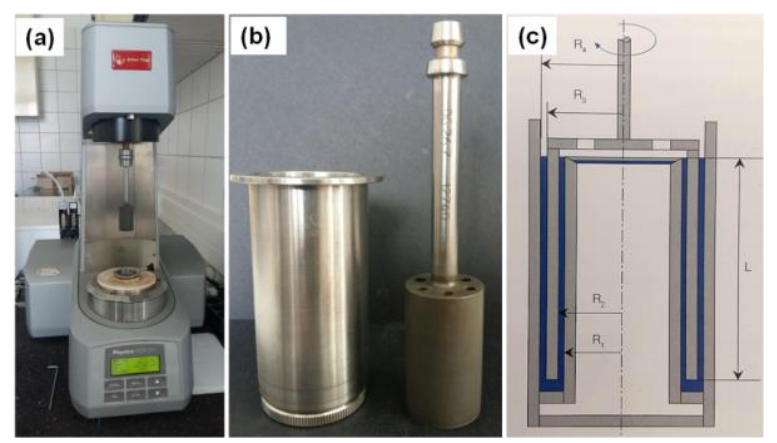

12. ábra. Az Anton Paar Physica MCR 301 típusú reométer (a) és a DG 26.7 típusú mérőfej (b) fotója, valamint a mérőfej sematikus (hosszmetszeti) ábrája (c).

A rendszerek pH értékeit 0,1 M-os HCl-, ill. 0,1 M-os NaOH-oldat hozzáadásával állítottam be a kívánt pH értékekre és az így elkészített minták reológiai jellemzése 24 óra után történt, a mérések előtt a beállított $\mathrm{pH}$ értékeket újra ellenőriztem. A pH mérés során a Metrohm, $827 \mathrm{pH}$ lab nevü készüléket használtam.

\subsubsection{Atomerő mikroszkópia}

Az LDO/ p(PFDAk) kompozit filmek nano-érdességét Atomi Erő Mikroszkóp (AFM) segítségével jellemeztem. Az AFM-képek Nanoscope III. típusú Digital Instruments (USA) szkenerrel készültek, melynek piezo kristálya x és y irányban $12,5 \mu \mathrm{m}$, z irányban $3 \mu \mathrm{m}$ mozgatásra képes. Az alkalmazott szilícium tủ egy Veeco Nanoprobe Tips RTESP modell volt (125 $\mu \mathrm{m}$ tűhossz, $300 \mathrm{kHz}$ frekvencia, $40 \mathrm{~N} / \mathrm{m}$ rugóállandóval), a méréshez pedig tapping (kalapáló) üzemmódot választottam.

\subsubsection{A felületi érdesség profilometriás meghatározása}

A felület érdességének megállapítására igen sokféle készülék alkalmas. Az LDO/ p(PFDAk) kompozit filmek felületi érdességét az SZTE-TTIK, Fizikus Tanszékcsoport, Optikai és Kvantumelektronikai Tanszéken található Dektak 8 (Veeco) típusú profilométer készüléken végeztem el. A mérés során egy gyémánttü állandó sebességgel halad a minta felületén, majd horizontális és vertikális irányú elmozdulása analóg jelet generál, ami a számítógépes kiértékelés után a monitoron jeleníthető meg. A szkennelési hossz tetszőlegesen változtatható $50 \mu \mathrm{m}-50 \mathrm{~mm}$ között. A kompozit filmek mérésekor alkalmazott szkennelési hossz $5 \mathrm{~mm}$ és a türe ható nyomóerő pedig $3 \mathrm{mg}(29,4 \mu \mathrm{N})$ volt. A felületi érdesség kifejezésére különböző érdességi mutatók 
használatosak, mint amilyen az átlagos érdesség (average roughness, $R_{a}$ ) vagy a négyzetes durvaság (root-mean-square roughness, $\mathrm{R}_{\mathrm{q}}$, ill. gyakran w) (13. ábra).
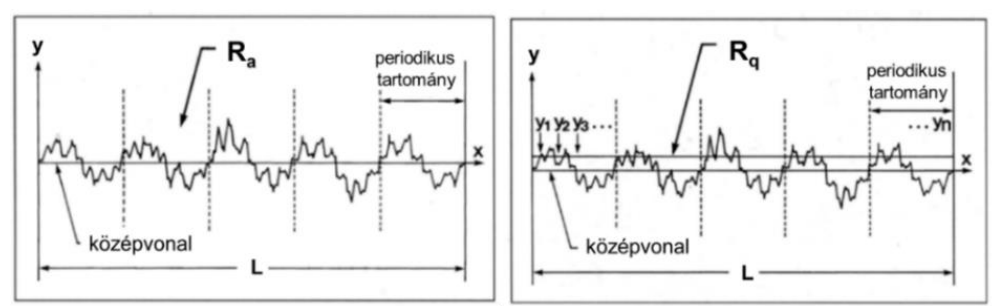

13. ábra. A felületi érdesség kifejezése átlagos érdesség $\left(R_{a}\right)$, ill a négyzetes durvaság $\left(R_{q}\right)$ érdességi mutatókkal.

Az átlagos érdesség és a négyzetes durvaság mérőszáma a következő összefüggésekből (12. és 13. egyenlet) határozhatók meg [94, 95]:

$$
\begin{aligned}
& R_{a}=\frac{1}{n} \sum_{i=1}^{n}\left|h_{i}-\bar{h}\right| \\
& R_{q}=\sqrt{\frac{1}{n} \sum_{i=1}^{n}\left(h_{i}-\bar{h}\right)^{2}}
\end{aligned}
$$

ahol $n$ a mérési pontok száma, $h_{i}$ az adott pont távolsága egy tetszőleges, de a középsíkkal párhuzamos felülettől mérve és $\bar{h}$ a középsík távolsága a vele párhuzamos viszonyítási síktól.

3.3.13 Kompozit rétegek nedvesedési tulajdonságainak meghatározása

Az előállított LDO/ p(PFDAk) kompozit rétegek vízre történő nedvesedési tulajdonságait peremszög mérésekkel jellemeztem. A peremszög értékek meghatározásához egy Easy Drop (Krüss GmbH, Hamburg, Németország) müszert (14. ábra) alkalmaztam.

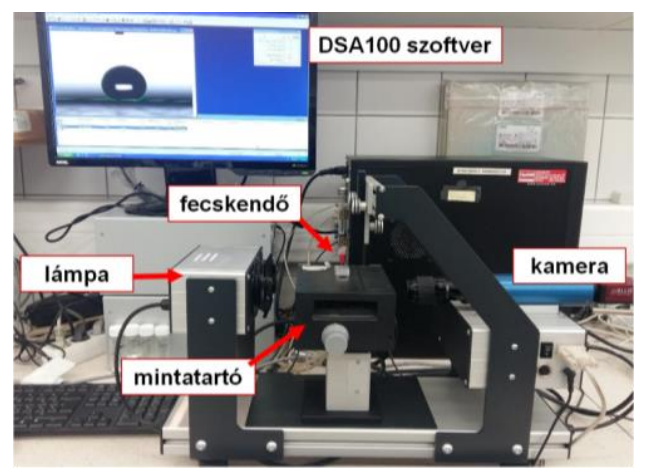

14. ábra. A peremszög mérések során alkalmazott Krüss, Easy Drop müszer fotója. 
A cseppentéseket egy $0,5 \mathrm{~mm}$ átmérőjű acél tüvel felszerelt fecskendővel végeztem és a felületekre 6-8 $\mu \mathrm{L}$ térfogatú ioncserélt vízcseppeket vittem fel. A mérések légköri atmoszférán és szobahőmérsékleten $\left(25^{\circ} \mathrm{C}\right.$-on $)$ zajlottak.

A kompozit rétegekre helyezve a vízcseppet az valamilyen szöggel illeszkedik a szilárd felszínhez [96]. Az illeszkedési szög, más néven peremszög ( $\Theta_{\mathrm{w}}$, kontaktszög) értékét a Youngegyenlet szerint a következő összefüggéssel definiálható (14. egyenlet):

$$
\cos \theta=\frac{\left(\gamma_{S G}-\gamma_{S F}\right)}{\gamma_{F G}}
$$

ahol a $\gamma_{S G}$ a szilárd-gőz, $\gamma_{S F}$ a szilárd-folyadék és $\gamma_{F G}$ a folyadék-gőz határfelületi feszültség értékek.

Drelich módszere alapján [97] az LDO/ p(PFDAk) kompozit rétegek további nedvesedési tulajdonságainak meghatározásához ún. cseppfelépítési és cseppelvételi technikával (15. ábra), haladó $\left(\Theta_{A d v}\right)$ és hátráló $\left(\Theta_{R e c}\right)$ peremszögeket határoztam meg.
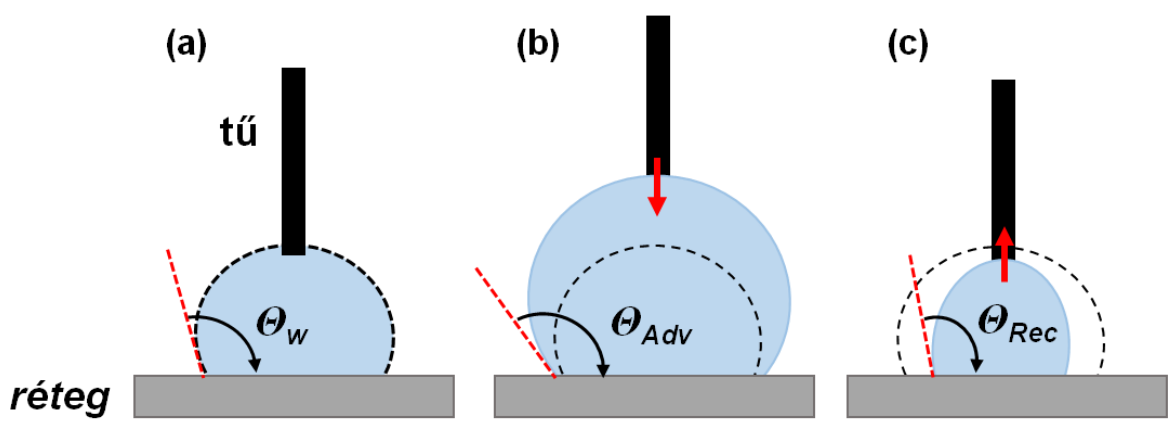

15. ábra. A cseppfelépítési és cseppelvételi technika (kontaktszög $\left(\Theta_{w}\right)(\mathbf{a})$, haladó $\left(\Theta_{A d v}\right)(\mathbf{b})$ és hátráló $\left(\Theta_{R e c}\right)(\mathbf{c})$ peremszögek) sematikus ábrája.

A kapott haladó $\left(\Theta_{A d v}\right)$ és hátráló $\left(\Theta_{R e c}\right)$ peremszög értékekből, az ioncserélt víz felületi feszültség értékének $\left(\gamma_{1}, 72,1 \mathrm{mN} / \mathrm{m}\right)$, valamint a peremszög hiszterézis ismeretében, meghatározható volt a kompozit rétegek látszólagos felületi szabad energiája $\left(\gamma_{\mathrm{s}}{ }^{\text {tot }}\right)$ az alábbi összefüggés ismeretében (15. egyenlet) [98]:

$$
\gamma_{S}^{t o t}=\left(\frac{\gamma_{1}\left(1+\cos \theta_{A d v}\right)^{2}}{\left(2+\cos \theta_{R e c}+\cos \theta_{A d v}\right)}\right)
$$




\subsubsection{Fotokatalitikus hatékonyság meghatározása}

\section{Fotokatalitikus tulajdonságok meghatározása S/L határfelületen}

A 3.2.9. fejezetben előállított $\mathrm{LDO} / \mathrm{p}(\mathrm{PFDAk})$ hibrid rétegek hatékonyságának vizsgálata során benzoesav modell molekula fotokatalitikus bontását vizsgáltam szilárd/folyadék (S/L) határfelületen. A bontási kísérleteket megelőzően, benzoesav kalibrációs oldatsorozatot készítettem. Az oldatokra felvett abszorbancia spektrumokból (Melléklet 1. M (a) ábra) meghatároztam a kalibrációs egyenest (Melléklet 1. M (b) ábra), majd ezen egyenes felhasználásával határoztam meg a hibrid rétegek által bontott benzoesav mennyiségét.

A fotokatalitikus mérések során a $25 \mathrm{~cm}^{2}$ felületü hibrid rétegeket $40 \mathrm{~mL} 0,17 \mathrm{~g} / \mathrm{L}$ benzoesav vizes oldatába merítettem és egy kvarclemezt helyeztem a reakcióedény tetejére, elkerülve az oldat párolgását a bevilágítás során (16. (a) ábra). A benzoesav fotooxidációját Ocean Optics UV-VIS USB4000 típusú diódasoros spektrofotométerrel követtem, 4 órás bevilágítási időket alkalmazva. Az összeállított rendszereket szobahőmérsékleten $\left(25,0 \pm 0,5^{\circ} \mathrm{C}\right)$, állandó kevertetés mellett, $5 \mathrm{~cm}$ távolságra helyeztem az alkalmazott fényforrástól (15 W-os GCL307T5L/CELL LightTech, UV-A fényforrás ( $\mathrm{S} 1$ fénycső); $\lambda_{\max }=365 \mathrm{~nm}, 5 \mathrm{~cm}$ távolságon mért teljesítménye: $6,38 \mathrm{~mW} / \mathrm{cm}^{2}$ ). Az S1 fényforrás emissziós spektruma a 16. (b) ábrán látható. A bevilágítások előtt 15 perces adszorpciós időket alkalmaztam.

(a)

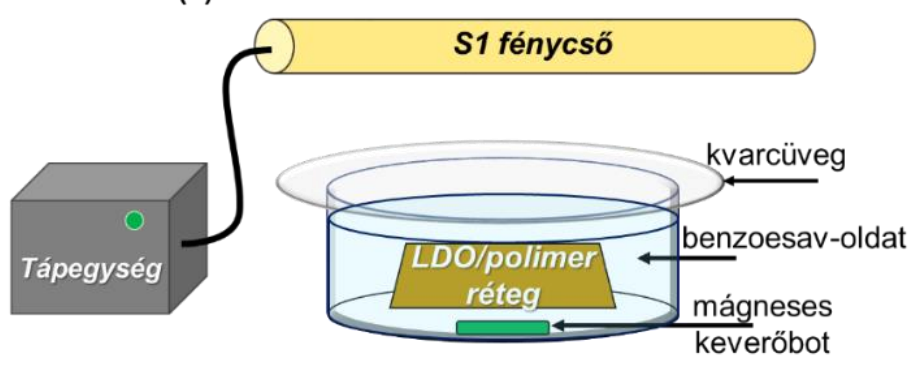

(b) UV-B UV-A $\quad \lambda_{\max }=365 \mathrm{~nm}$

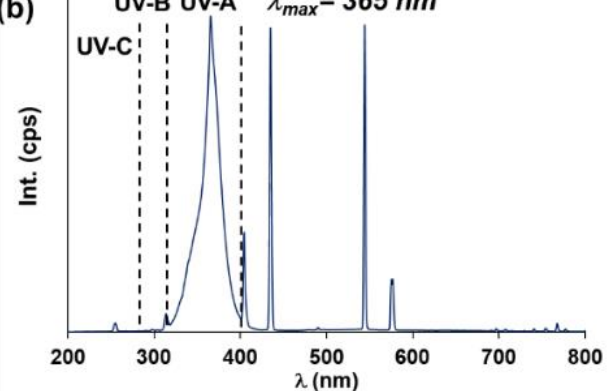

16. ábra. A mérések során alkalmazott kísérleti elrendezés sematikus ábrája (a) és az alkalmazott fényforrás ( $\mathrm{S} 1$ fénycső, $5 \mathrm{~cm}$ távolságon mért teljesítménye: $6,38 \mathrm{~mW} / \mathrm{cm}^{2}$ ) emissziós spektruma (b).

\section{Fotokatalitikus tulajdonságok meghatározása $S / G$ határfelületen}

A 3.2.11. fejezetben előállított $\mathrm{TiO}_{2} / \mathrm{HAp} / \mathrm{p}$ (EA-co-MMA) polimer kompozit rétegek bontási hatékonyságának vizsgálata során etanol tesztmolekula fotodegradációját vizsgáltam szilárd/gáz (S/G) határfelületen. Az etanol koncentrációjának változását gázkromatográfiás (GC) mérésekkel követtem, 2 órás bevilágítási időt alkalmazva. A mérések kivitelezése során az $50 \mathrm{~cm}^{2}$ felületü kompozit rétegeket egy FV-165 típusú reaktorba helyeztem $\left(\mathrm{V}_{\mathrm{FV}-165}=165 \mathrm{~cm}^{3}\right)(\mathbf{1 7}$. (a) ábra), mely 
a GC készülékhez (Shimadzu GC-14B) közvetlenül csatlakoztatható. A kvarclemezzel ellátott reaktor (FV-165) fölé helyeztem a mérés során alkalmazott LED típusú $\left(\lambda_{\max }=405 \mathrm{~nm}, 5 \mathrm{~cm}\right.$ távolságon mért teljesítménye: $24,28 \mathrm{~mW} / \mathrm{cm}^{2}$ ) fényforrást (17. (b) ábra).
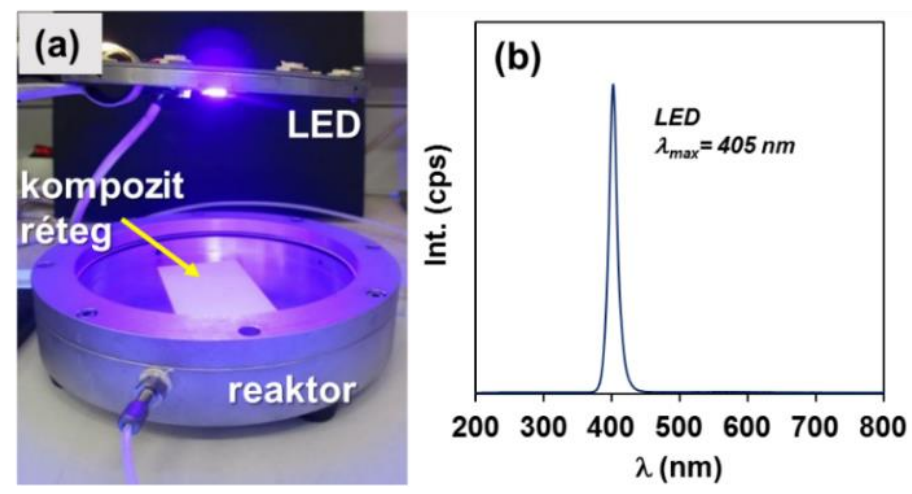

17. ábra. Az etanol tesztmolekula fotodegradációja során alkalmazott kísérleti elrendezés (a) és a

LED típusú fényforrás emissziós spektruma (b), $5 \mathrm{~cm}$ távolságon mért teljesítménye: 24,28 $\mathrm{mW} / \mathrm{cm}^{2}$.

A mérések során $5 \mu \mathrm{L}$ etanolt $(0,36 \mathrm{mM})$ és $2,5 \mu \mathrm{L}$ vizet injektáltam a reaktortérbe. A bevilágítások előtt 30 perces adszorpciós időket alkalmaztam. A lámpa és a film közötti távolság minden esetben $5 \mathrm{~cm}$ volt.

3.3.15 A fotokatalizátor kompozit rétegek felületén képződő szabadgyök meghatározása

A 3.2.9. fejezetben előállított $\mathrm{LDO} / \mathrm{p}(\mathrm{PFDAk})$ polimer kompozit rétegek felületi reaktivitását luminometriás módszerrel is mértem a Sirius L típusú egycsöves luminométer (Titertek Berthold, Germany) alkalmazásával. A módszer mérési elve az, hogy fotokatalitikus reakciók során keletkező reaktív gyökök pl. szuperoxid $\left(\mathrm{O}_{2}^{-}\right)$, hidrogén- peroxid $\left(\mathrm{H}_{2} \mathrm{O}_{2}\right)$, vagy hidroxil- gyök ( $\left.{ }^{\circ} \mathrm{HO}\right)$ kölcsönhatásba lépnek a luminol (5-amino-2,3-dihidro-1,4-ftálazindion, Sigma-Aldrich, > 97 \%) molekulával [99] (18. ábra), ennek hatására kék fényt emittál (424 nm), mely intenzitása a keletkező reaktív gyökök számával arányos és luminométerrel detektálható.

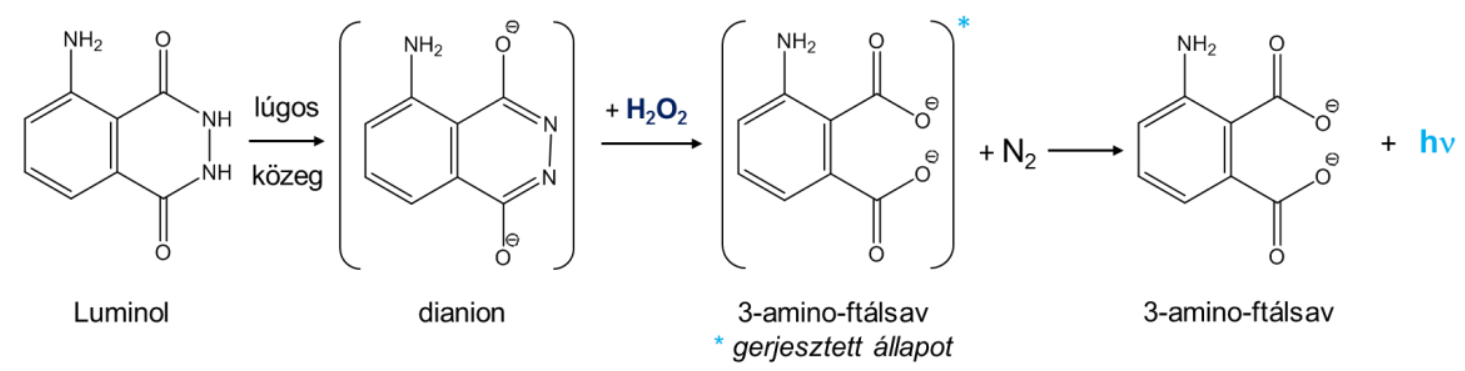

18. ábra. A luminol molekula reakciója hidrogén-peroxiddal. 
A mérések megkezdése előtt egyre növekvő koncentrációval (rendre $0 ; 0,25 ; 0,5 ; 1,0 ; 2,5$ és 5 $\mathrm{mM}$ ) rendelkező $\mathrm{H}_{2} \mathrm{O}_{2}$ vizes-oldatsorozatot készítettem, majd ezek $100 \mu \mathrm{L}$-es térfogataihoz $100 \mu \mathrm{L}$ 1,69 mM-os vizes luminol oldatot adtam és a luminométerrel meghatározott kibocsájtott fényintenzitásokból (RLU/s: relatív fényegység) meghatároztam a kalibrációs egyenest (Melléklet 2. M ábra). A kapott kalibrációs egyenes felhasználásával határoztam meg a fotokatalitikus folyamat során keletkező reaktív gyökök mennyiségét a kompozit rétegek jelenlétében. Ennek során a $25 \mathrm{~cm}^{2}$ felületű $\mathrm{LDO} / \mathrm{p}$ (PFDAk) polimer kompozit filmeket $40 \mathrm{~mL}$ ioncserélt vízbe merítettem és a folyadék rázóasztallal történő enyhe kevertetése mellett LED típusú fényforrással $\left(\lambda_{\max }=405 \mathrm{~nm}\right)$ világítottam be. A fényforrást a folyadékoszloptól jelen esetben is $5 \mathrm{~cm}$ magasságba helyeztem és a reakcióedény tetejére kvarclemezt helyeztem, elkerülve a párolgást a bevilágítás során (19. ábra).

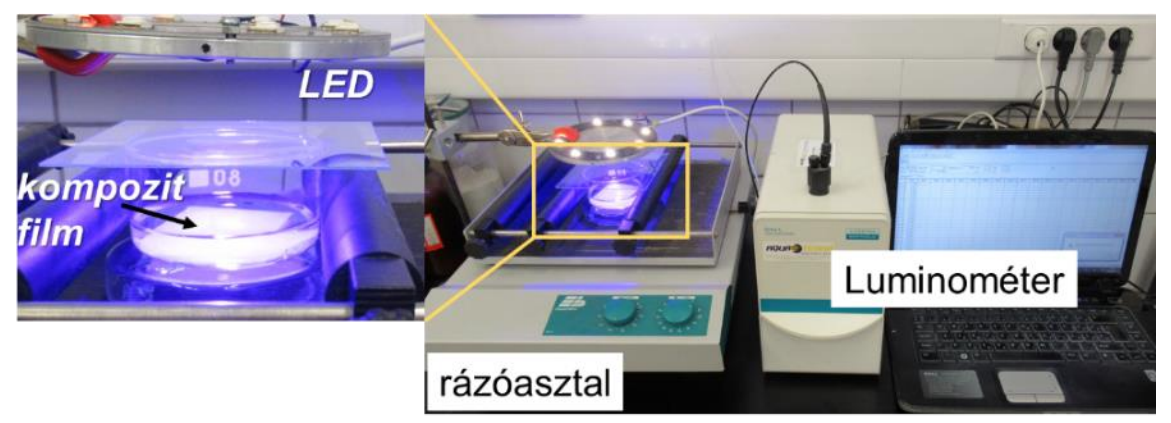

19. ábra. A luminometriás mérések során alkalmazott kísérleti elrendezés.

Adott mintavételi időpontokban $(0 ; 2,5 ; 5 ; 10 ; 15 ; 20 ; 30 ; 40 ; 50 ; 60 ; 75$ és 90 percben $) 100 \mu \mathrm{L}$ mintához $100 \mu \mathrm{L}$ 1,69 mM-os luminolt adtam, majd a müszerbe helyezve mértem a minták által kibocsájtott fényintenzitást (RLU/s: relatív fényegység) a Sirius L kiértékelő szoftver segítségével. A minták összehasonlíthatóságának érdekében, minden minta mérése esetén a 30. másodpercben regisztrált adat értékét vettem alapul. A méréseket pedig minden esetben szobahömérsékleten $(\mathrm{T}=$ $\left.25,0 \pm 0,5^{\circ} \mathrm{C}\right)$ végeztem.

\subsubsection{Baktériumok adhéziójának vizsgálata kompozit rétegek felszínén}

A mikrobiológiai kísérleteket a Ljubjlanai Egyetem Egészségügyi Karán végeztem. A kísérletek kivitelezése során a Pseudomonas aeruginosa (P. aeruginosa) ATCC 27853 és Escherichia coli (E. coli) ATCC 35218 Gram-negatív, ill. Staphylococcus aureus (S. aureus) ATCC 25923 Grampozitív baktériumok (nemzetközileg is elfogadott ATCC törzsek) adhézióját vizsgáltam a változó összetételü 0, 20, 40, 60, 80 m/m\% LDO tartalmú LDO/p(PFDAk) kompozit rétegek felszínén.

A vizsgálatok megkezdése előtt, a kísérletek során alkalmazott anyagokat (táptalaj, tápoldat, 10xPBS-puffer, ioncserélt víz) és eszközöket (üvegedényeket, üvegbotokat, csipeszeket, 
kémcsöveket, pipetták tipjeit) 20 percig $121{ }^{\circ} \mathrm{C}$-on autoklávban sterilizáltam, majd a vizsgálat előtt hagytam lehülni szobahőmérsékletre. A vizsgálandó mintákat (üveghordozón kialakított LDO/ p(PFDAk) kompozit rétegeket) és a vizsgálat során használt mintatartókat pedig 1 órán keresztül UV-lámpa alatt $(\lambda=254 \mathrm{~nm})$, steril elszívófülkében tartottam. A 10xPBS puffer elkészítése során 80 g NaCl-ot (99,8 \%, Sigma-Aldrich), 2 g KCl-ot (99\%, Sigma-Aldrich), 14,4 g Na $\mathrm{HPO}_{4}$-ot (99 $\%$, Sigma-Aldrich) és 2,4 g K $\mathrm{KH}_{2} \mathrm{PO}_{4}$-ot (99\%, Sigma-Aldrich) 1 liter ioncserélt vízben oldottam és $1 \mathrm{M}$-os $\mathrm{HCl}$ - és $\mathrm{NaOH}$-oldatok hozzádásával állítottam be $\mathrm{pH}$-ját $\mathrm{pH}=7,4$ értékre.

A baktériumokat a mikrobiológiai vizsgálatok előtt táptalajra oltottam, majd a leoltott baktériumtenyészeteket 24 órán át $37^{\circ} \mathrm{C}$-on inkubáltam. Az táptalaj elkészítése során olyan agar készítményt (Nutrient Agar, Biolife, Italy) alkalmaztam, mely 15 g/L agart, 3 g/L szarvasmarha kivonatot (angolul: beef extract) és $5 \mathrm{~g} / \mathrm{L}$ peptont tartalmazott. A készítmény 2,3 grammját $100 \mathrm{~mL}$ ioncserélt vízben oldottam, $121^{\circ} \mathrm{C}$-on sterilizáltam, majd steril Petri csészékbe öntöttem és végül a szobahőmérsékletű táptalajokra (külön-külön) leoltottam a baktériumokat.

24 óra elteltével, a leoltott baktériumtenyészetekből egy-egy izolált telepet 50-50 mL steril tápoldatban szuszpendáltam, majd 18 órán át $37{ }^{\circ} \mathrm{C}$-on inkubáltam. A tápoldat (Nutrient Broth, Biolife, Italy) $3 \mathrm{~g} / \mathrm{L}$ szarvasmarha kivonatot és $5 \mathrm{~g} / \mathrm{L}$ peptont tartalmazott. 18 óra elteltével (a baktérium sejtek exponenciális növekedési fázisuk végén, stacionárius fázisuk elején [100]) 1,33 $\mathrm{mL}\left(1 \times 10^{8}-1 \times 10^{9} \mathrm{CFU} / \mathrm{mL}\right)$ bakterium-szuszpenziót $40 \mathrm{~mL}$ steril tápoldatban szuszpendáltam, a megfelelő $1 \times 10^{7}-1 \times 10^{8} \mathrm{CFU} / \mathrm{mL}$ koncentráció elérése céljából. A steril $1 \times 1 \mathrm{~cm}^{2}$-es LDO/ p(PFDAk) kompozit rétegeket $20 \mathrm{~mL}\left(1 \times 10^{7}-1 \times 10^{8} \mathrm{CFU} / \mathrm{mL}\right)$ baktérium-szuszpenziókba merítettem, majd 18 órán át $37^{\circ} \mathrm{C}$-on inkubáltam. Az inkubációs idő elteltével, a rétegeket a baktérium-szuszpenziókból kiemelve, 1xPBS pufferrel öblítettem (a 10xPBS puffert 10-szeresére

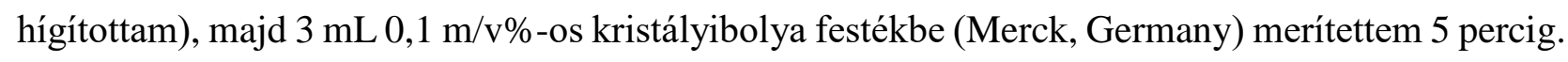
Ezzel a lépéssel a rétegek felszínén megtapadt baktérium sejteket festettem meg. A rétegeket a festékből kiemelve, egy újabb 1xPBS pufferrel történő öblítés követett. Végül $400 \mu \mathrm{L} 96$ \%-os etanolos öblítést alkalmazva (3 perc) kivontam a festék molekulákat a baktérium sejtekből. A kivont festék mintákat pedig optikai denzitást mérő fotométerrel (Infinite $200^{\circledR} \mathrm{PRO}$, Tecan Austria GmbH, microplate reader) mértem 620 nm-es hullámhossznál (OD 620$)$. A kísérletek során 3 párhuzamos mérést végeztem és kontroll vizsgálatok során pedig baktérium mentes tápoldatot alkalmaztam. 
3.3.17 Fotokatalizátor tartalmú kompozit rétegek antibakteriális tulajdonságának vizsgálata fluoreszcens mikroszkóp alkalmazásával

A 3.2.9. fejezetben elöállított LDO/ p(PFDAk) polimer kompozit rétegek közül a $80 \mathrm{~m} / \mathrm{m} \%$ LDO fotokatalizátor tartalomnál vizsgáltam a réteg antibakteriális tulajdonságát fluoreszcens jelölési eljárással. A kompozit réteg felszínén megtapadt, majd a fotokatalízis során sérült baktérium sejteket a Leica DM IL LED FLUO típusú fluoreszcens mikroszkópos mérésekkel vizsgáltam. A kísérelt kivitelezése során 0,2 mL fluoreszcens festék kit-tel (LIVE/DEAD ${ }^{\circledR}$ Bac Light $^{\mathrm{TM}}$ Bacterial Viability kit L7007, Life Technologies, Magyarország) jelölt Pseudomonas aeruginosa ATCC 27853 tesztbaktérium szuszpenziót a $80 \mathrm{~m} / \mathrm{m} \%$ LDO/ p(PFDAk) kompozit réteg felületre $(2 \times 2$ $\left.\mathrm{cm}^{2}\right)$ jutattam és LED típusú $\left(\lambda_{\max }=405 \mathrm{~nm}\right)$ fényforrással világítottam be 2 órán keresztül. A baktérium szuszpenzió koncentrációja $1 \times 10^{5}-5 \times 10^{5} \mathrm{CFU} / \mathrm{mL}$ volt. A fluoreszcens festék kit két összetevőből áll, a SYTO 9 festék, mely átjut az élő baktérium sejtfalán, és a propidium-jodid fluoreszcens festék (PI), mely nem képes behatolni az élő baktérium sejtfalába, csak ha a sejtfal sérült. Így a baktériumok életképességének fluoreszcens mikroszkópos vizsgálata során, a Leica mikroszkóp megfelelő szürőinek alkalmazása mellett, az élő baktérium sejtek zölden (L5-ös szürő), a sérült vagy elpusztult baktérium sejtek pedig piros színt (N2.1-es szürő) emittálnak.

\subsubsection{LDH oldása szintetikus gyomornedv (SGF) közegben}

A hatóanyag hordozó 2:1 Mg/Al-LDH oldását szintetikusan előállított gyomornedvben (SGFoldatban) vizsgáltam, $\mathrm{pH}=1,5$ értéken. Az SGF-oldat készítése során 0,745 g KCl-ot (99,5-100 \%, Reanal) és 0,25 g pepszint (1:10000 NF; $2000 \mathrm{U} / \mathrm{g}$ activity, Molar Chemicals Kft.) $50 \mathrm{~mL}$ ioncserélt vízben oldottam, majd az oldathoz 0,835 mL tömény HCl-at (37 \%, Molar Chemicals Kft.) adtam a kívánt $\mathrm{pH}=1,5$ érték eléréséhez [101, 102]. Az 50 mL SGF-oldathoz (a 3.2.1. fejezetben szintetizált) $0,5 \mathrm{~g} \mathrm{LDH}$ pormintát adtam. Az LDH oldódását gravimetriásan ill. röntgendiffrakciós mérésekkel (Bruker D8 röntgendiffraktométerrel végeztük, $\mathrm{CuK}_{\alpha}$ sugárzás: $\lambda=0,154 \mathrm{~nm}, 40-50 \mathrm{kV}, 30-40 \mathrm{~mA}$, $2-30^{\circ}(2 \Theta)$ szögtartományban, szobahőmérsékleten) követtem nyomon. A $0,01 \mathrm{~g} / \mathrm{mL} \mathrm{LDH}$ szuszpenziót (SGF közegben, pH=1,5) szobahőmérsékleten kevertettem, majd adott idő elteltével 1-1 mL mintát vettem és (10 perc, $14.500 \mathrm{rpm})$ centrifugálást követően szárítószekrényben $80{ }^{\circ} \mathrm{C}$ on beszárítottam. A kísérletek során 3 párhuzamos mérést végeztem.

\subsubsection{KYNA hatóanyag leadás vizsgálata}

A KYNA hatóanyag leadását az emberi nyál és gyomornedv pH-ján, azaz 6,70 [103, 104] és 1,5ös [101] pH értékeken vizsgáltam, egy dializáló cellulóz membrán (cut-off= 12-14kDa, Sigma 
Aldrich) alkalmazása mellett. A bemérendő kompozitot, a hatóanyag tartalma szerint, előzetes kalibráció alapján úgy választottam meg, hogy a mérendő komponens (KYNA) abszorbanciája ne haladja meg a 1,5-es abszorbancia értéket, akkor sem, ha az összes hatóanyag kioldódik 4 óra elteltével.

A PBS-puffer (pH=6,70) közegü, $1 \mathrm{~mL}$ 1,6 mg/mL koncentrációjú KYNA-oldatot, ill. $1 \mathrm{~mL}$ (3.2.7. fejezetben előállított) KYNA/ LDH szuszpenziót (1,6 mg/mL KYNA-ra nézve), dializáló membrán hártyába (átmérője $1 \mathrm{~cm}$, hossza $10 \mathrm{~cm}$ ) pipettáztam. A hatóanyag, ill. kompozit tartalmú membránokat pedig 100-100 mL PBS-pufferbe $(\mathrm{pH}=6,70$ és 1,5) merítettem, függőleges helyzetben. A közeget folyamatos kevertetés mellett $37^{\circ} \mathrm{C}$-on inkubáltam és adott időpontokban mintát vettem. A kinurénsav hatóanyag kioldódását Ocean Optics UV-VIS USB2000 típusú diódasoros spektrofotométerrel követtem, $\lambda=250-350 \mathrm{~nm}$ hullámhossz tartományon.

A hatóanyag leadás kísérleteket megelőzően, kinurénsav kalibrációs oldatsorozatot készítettem $\mathrm{pH}=6,7$ és 1,5 értékeken. Az oldatokra felvett abszorbancia spektrumokból meghatároztam a kalibrációs egyeneseket (Melléklet 3. M ábra), majd ezen egyenesek felhasználásával határoztam meg a felszabadult KYNA hatóanyag mennyiségeket az egyes vizsgált pH értékeken.

3.3.20 LDH/ $\mathrm{Ag}^{0}$-montmorillonit két komponensű rendszer $\mathrm{pH}$-függésének vizsgálata

Az LDH/ $\mathrm{Ag}^{0}$-montm. rendszer pH-függő sajátságának vizsgálatához olyan $3 \mathrm{~m} / \mathrm{m} \%$-os koncentrációval rendelkező szuszpenziókat készítettem, ahol az antibakteriális tulajdonságokkal rendelkező $\mathrm{Ag}^{0}$-montmorillonit, ill. a szférikus szerkezetű $\mathrm{LDH}$ aránya $75 / 25 \mathrm{~m} / \mathrm{m} \%$ volt. Az előállított minták antibakteriális hatásáért felelős $\mathrm{Ag}^{0}$-montmorillonit tartalmának felszabadulását $\mathrm{pH}=3$-as és 6-os értéken vizsgáltam az idő függvényében. Ehhez egy vertikális diffúziós cellát (módosított Franz-cellát) alkalmaztam (20. ábra).

A cellát eredetileg in vivo hatóanyag leadás (ill. penetráció) meghatározására használják különböző pórusméretü membránok felhasználásával. A mérések során a szabványos membránok helyett egy $45 \mu \mathrm{m}$-es pórusmérettel rendelkező szitaszövetet használtam.
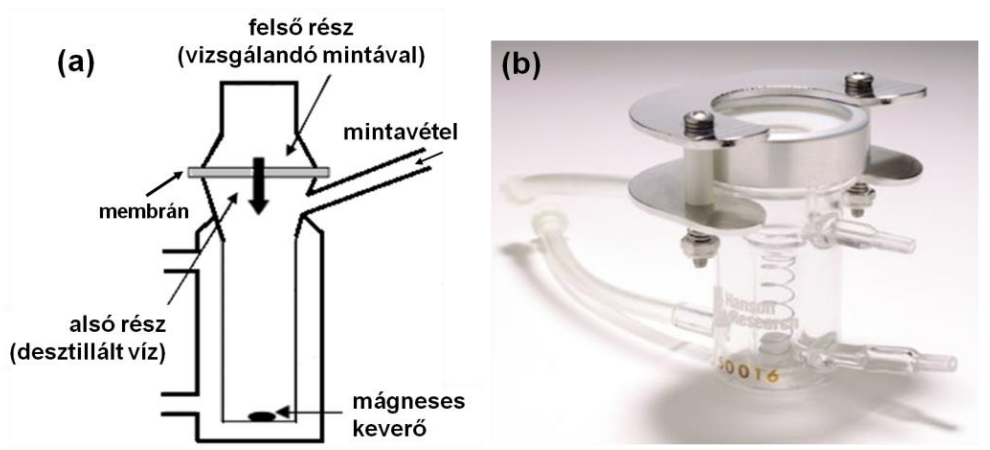

20. ábra. A kioldódási tesztek során használt vertikális diffúziós cella sematikus ábrája (a) és fotója (b). 
A kísérletek során a cella ( $1 \mathrm{~mL}-$ es térfogatú) felső részébe 0,088 g pH=3,0 értékkel rendelkező szuszpenziót helyeztem, majd egy órán keresztül spektrofotometriásan (Ocean Optics UV-VIS USB4000 típusú diódasoros spektrofotométer) regisztráltam a membránon az alsó (4mL térfogatú) térrészbe átjutó $\mathrm{Ag}^{0}$ - montmorillonit mennyiségét az előzetesen elkészített kalibrációs egyenes felhasználásával (Melléklet 4. M ábra). Ezt követően ugyanazon mintához annyi lúgot adtam, hogy annak pH értéke 6 legyen, majd újabb egy órán keresztül vizsgáltam a membránon átjutott hatóanyag mennyiségét. 


\section{Kísérleti eredmények és értékelésük}

Doktori munkám során különböző felhasználásokra alkalmas kompozitokat állítottam elő LDH, LDO, montmorillonit, ill. HAp szervetlen, valamint akrilát alapú polimer komponensek felhasználásával. A 21. ábra összefoglalja az előállított komponensek és az ezekből kialakított kompozitok sematikus ábráját, a kialakított kompozitok lehetséges alkalmazási területeinek megjelölésével. Az eredményeket az ábrának megfelelően mutatom be a következő fejezetekben.
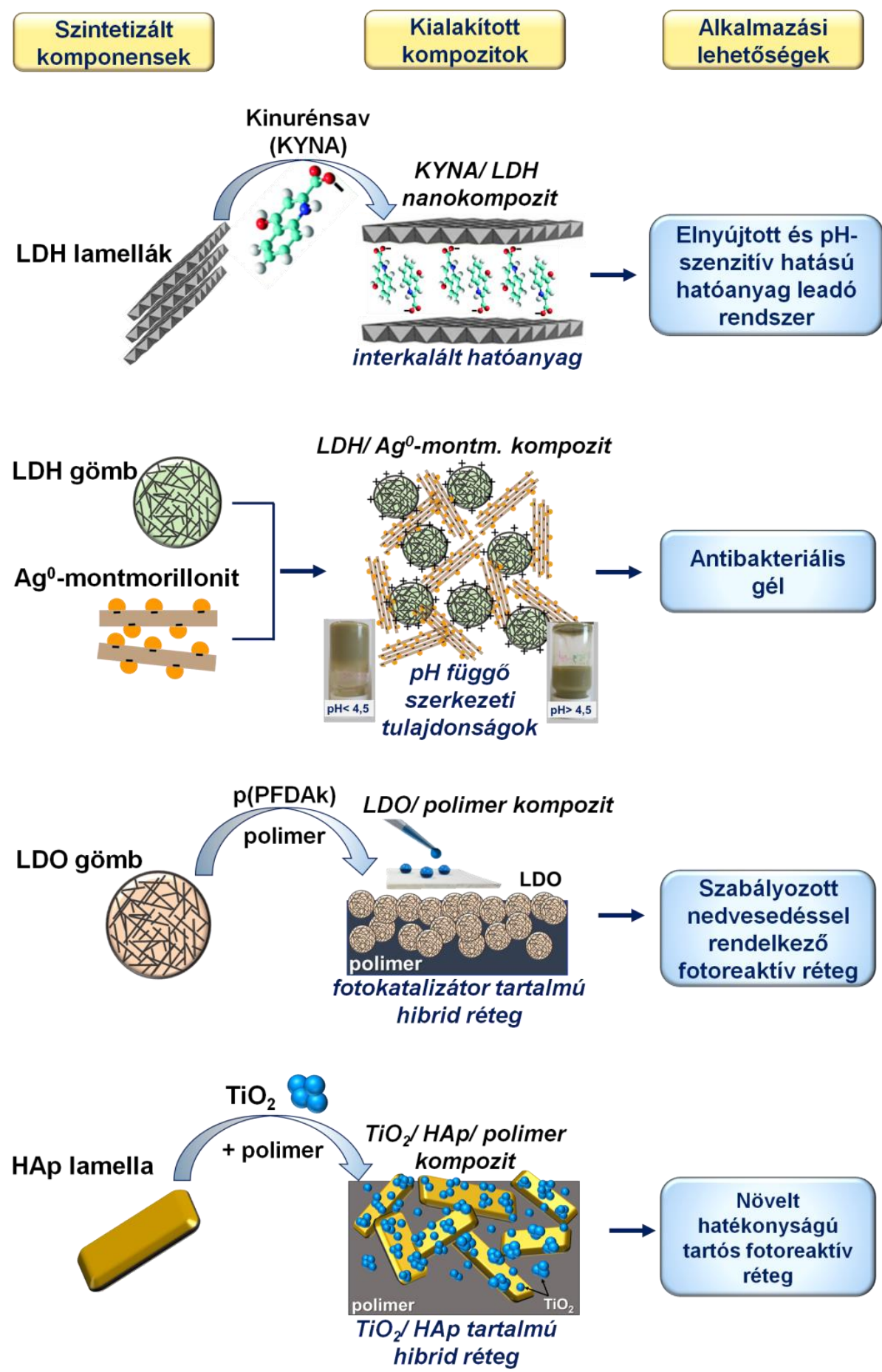

21. ábra. Az előállított komponensek és kialakított kompozitok összefoglaló sematikus ábrája, a lehetséges alkalmazási területek megjelölésével. 


\subsection{Lamellás szerkezetü LDH és kinurénsav/ LDH kompozitok jellemzése}

\subsubsection{Lamellás szerkezetü LDH szerkezeti jellemzése}

A kinurénsav hatóanyagot tartalmazó LDH alapú kompozit kialakításához szolgáló LDH szerkezetének jellemzésére röntgendiffrakciós mérést végeztem a 3.3.1. pontban leírtak szerint, a röntgendiffraktogramot a 22. ábra mutatja.

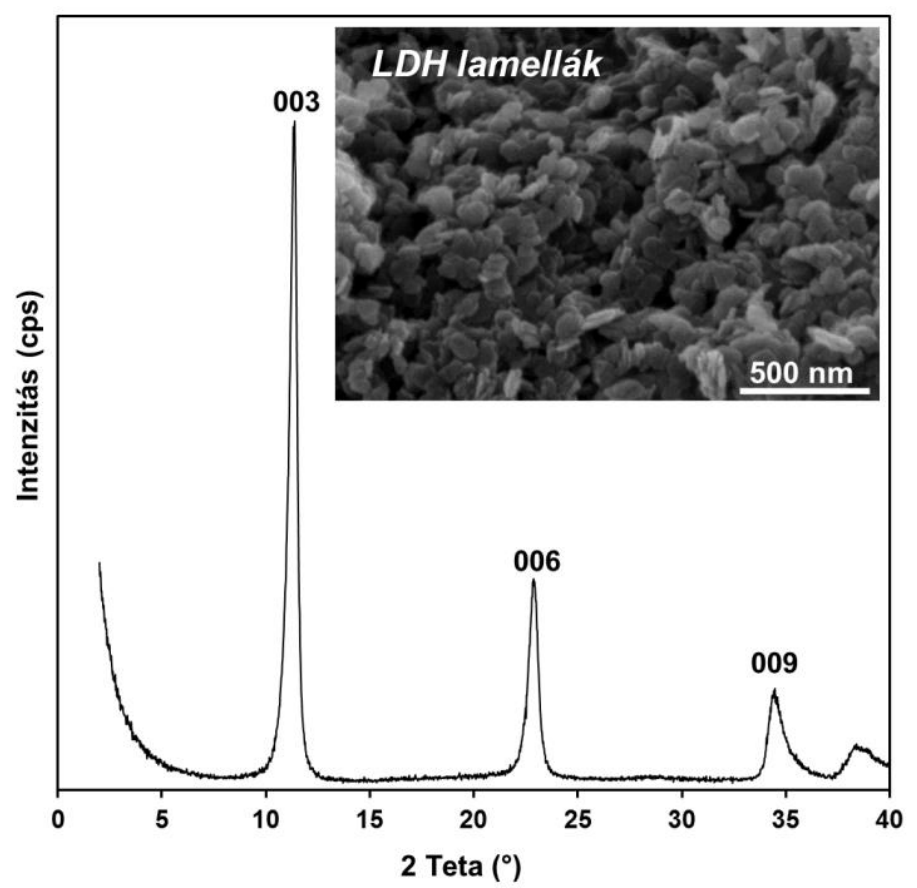

22. ábra. A lamellás szerkezetü $2: 1 \mathrm{Mg} / \mathrm{Al}-\mathrm{LDH}$ porminta röntgendiffraktogramja és egy reprezentatív SEM felvétele.

Látható, hogy az LDH elsődleges és másodlagos reflexiói a $2 \Theta=11,39^{\circ}(003)$ és $22,82^{\circ}$-nál (006) találhatóak, mely 7,75 Å és 3,86 Å bázislap távolságnak felel meg. A 22. ábrába beszúrt pásztázó elektronmikroszkópos (SEM) felvétel jól igazolja az előállított LDH minta lamellás morfológiáját. Ez a szerkezet és morfológia a hidrotermális körülmények között elöállított 2:1 Mg/Al-LDH-ra jellemző és az irodalmi adatokkal is jó egyezést mutat (JCPDS No. 89-0460) [105]. Nitrogén adszorpciós mérésekkel a minta fajlagos felületét is meghatároztam. A 23. (a) ábrán az LDH-ra kapott nitrogén adszorpciós izoterma látható. Adszorpciós hiszterézis figyelhető meg a kapott izotermán, mely valószínűsíti a pórusos szerkezet kialakulását. Az LDH-ra kapott fajlagos felület $a_{B E T}^{S}=114,96 \pm 0,48 \mathrm{~m}^{2} / \mathrm{g}$-nak, mikropórus térfogat $V_{m}=26,42 \mathrm{~cm}^{3} / \mathrm{g}$ STP-nek adódott. 


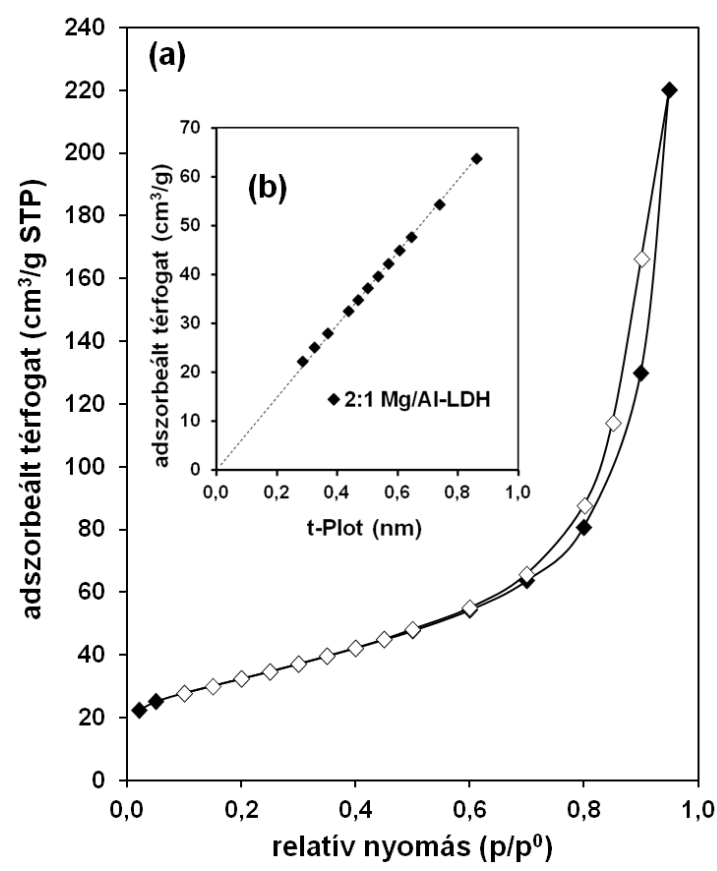

23. ábra. A 2:1 Mg/Al-LDH minta nitrogén adszorpciós izotermája (a) és t-Plot (b) ábrázolása.

Az LDH minta szerkezeti jellemzése mellett a későbbi interkalációs mechanizmus kivitelezése céljából meghatároztam az LDH hordozó fajlagos töltését is (24. ábra), a 3.3.3. pontban ismertetett töltés-titrálás alkalmazásával.

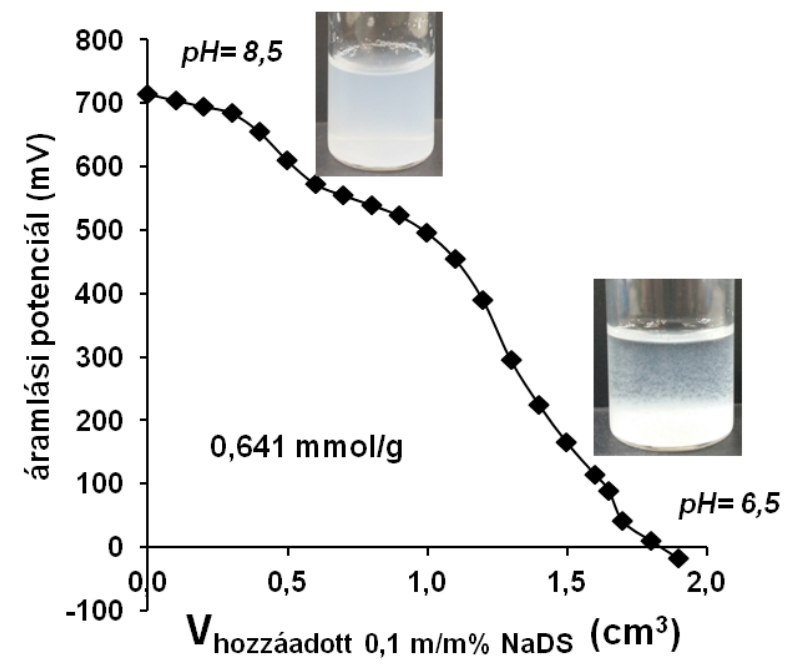

24. ábra. A $10 \mathrm{~mL} 0,1 \mathrm{~m} / \mathrm{m} \%$-os $2: 1 \mathrm{Mg} / \mathrm{Al}-\mathrm{LDH}$ szuszpenzió áramlási potenciál értéke a hozzáadott $0,1 \mathrm{~m} / \mathrm{m} \%$-os vizes tenzidoldat térfogatának függvényében.

A kapott titrálási görbén látható, hogy a pozitív töltésű LDH esetében a hozzáadott anionos tenzid (NaDS) mennyiségének növekedésével folyamatosan csökken a mért áramlási potenciál érték a semleges töltésállapot eléréséig. A töltéskompenzálási pont eléréséig az alklamazott tenzid mennyiségekből meghatároztam az LDH hordozó fajlagos töltését, mely 0,641 mmol/g-nak adódott. 
4.1.2 Rétegközi kinurénsav (KYNA) hatóanyagot tartalmazó LDH alapú kompozit előállítása és szerkezetvizsgálata

A kationos brucit LDH-rétegek rétegközi terükben cserélhető anionokat tartalmaznak lehetővé téve a biomolekulák egyszerü ioncsere reakcióval történő beépülését, mely révén bio-LDH nanohibrid rendszerek állíthatók elő.

A KYNA LDH rétegek közé történő interkalációját flureszcenciás és röntgendiffrakciós mérésekkel követtem nyomon. A mérések során meghatároztam az LDH adszorpciós kapacitását a KYNA-ra nézve. Ehhez szisztematikusan változtattam a KYNA/ LDH arányát és fluorometriásan mértem az egységnyi tömegü LDH által felvett KYNA mennyiségét (25. ábra). A mérések során a vizes KYNA-oldat koncentrációjának csökkenését követtem nyomon (25. ábra, beszúrt ábra), mely az interkalációnak volt köszönhető.

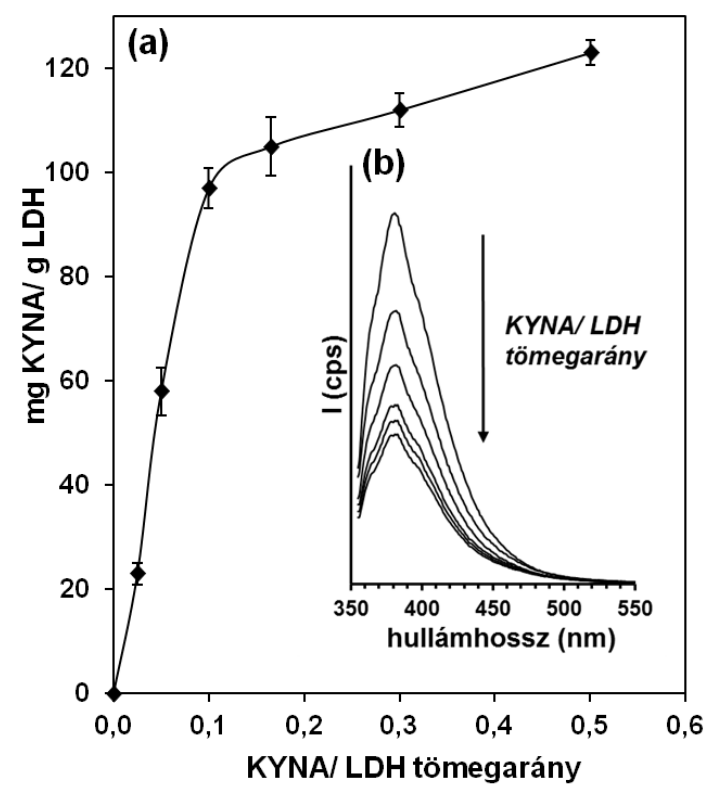

25. ábra. Az LDH lamellák által elektrosztatikusan megkötött KYNA mennyiségének alakulása a KYNA/ LDH tömegarányának növekedésével (a). Az interkalált KYNA mennyiségének meghatározása fluoreszcenciásan (b) $\left(\lambda_{\mathrm{ex}}=350 \mathrm{~nm} ; \lambda_{\mathrm{em}}=355-550 \mathrm{~nm}\right)$.

Az eredményekből látható, hogy kezdetben a KYNA tömegarány növekedésével közel lineárisan nő a felvett KYNA mennyisége, majd egy törést követően (10-15 \%-os KYNA tartalom) kis mértékben láthatunk növekedést. Megállapítottam, hogy $30 \%$-os KYNA tartalomnál, az egységnyi tömegü LDH kb. 12 \% KYNA felvételére képes. Figyelembe véve az LDH anioncsere-kapacitását (0,641 mmol/g), valamint a KYNA molekulatömegét $(189,17 \mathrm{~g} / \mathrm{mol})$, az elméleti értékek is azt mutatják, hogy kb. 120-130mg interkalálódhat maximálisan az LDH rétegek közé. 
Az interkaláció sikeres kimenetelét a 26. ábrán látható röntgendiffrakciós mérések is igazolják. A kiindulási LDH röntgendiffraktoramjához képest a KYNA-tartalmú LDH minta esetén a $2 \Theta=$ 11,39-nál található reflexió intenzitása lecsökken, és ezzel párhuzamosan újabb reflexió jelenik meg (26. ábra) $2 \Theta=4,11^{\circ}$-nál, mely $\mathrm{d}_{\mathrm{L}}=2,15 \mathrm{~nm}$-es bázislap-távolságnak felel meg.

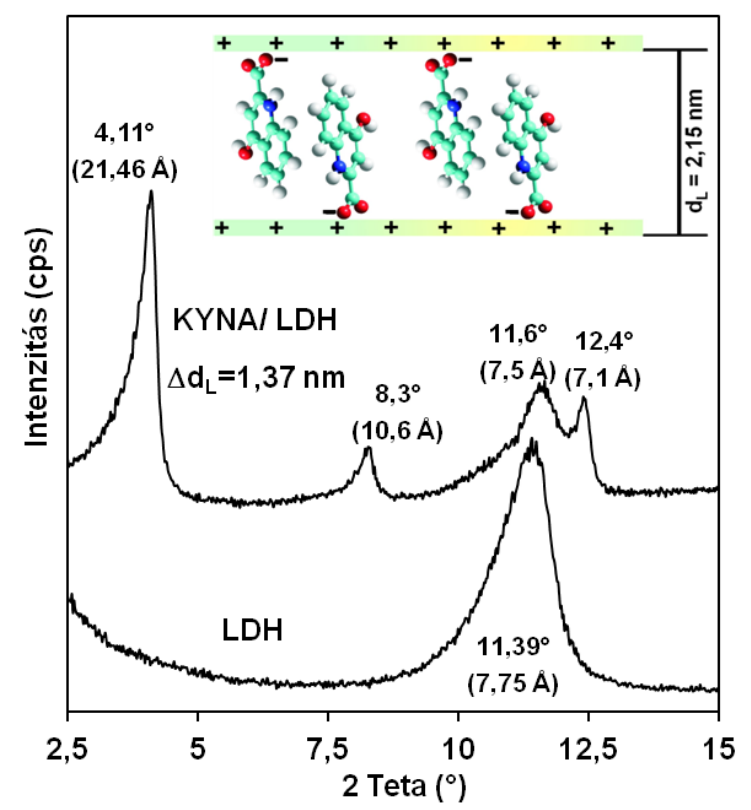

26. ábra. A kiindulási LDH és KYNA/ LDH interkalációs kompozit porminták röntgendiffraktogramjai.

Az LDH-ra jellemző rétegvastagság 4,7 Å, a lamellák közötti távolságot (d) pedig a következő összefüggésből számolható ki:

$$
\mathrm{d}=\mathrm{d}_{\mathrm{L}}-0,47 \mathrm{~nm}
$$

Az összefüggésben a $0,47 \mathrm{~nm}$ az $\mathrm{LDH}$ réteg vastagságát, a $\mathrm{d}_{\mathrm{L}}$ a bázislap-távolságot jelenti. $\mathrm{Az}$ összefüggés alapján, a KYNA/ LDH esetén a lamella közti távolság 1,67 nm-re növekedett. Annak igazolásaként, hogy a KYNA molekulák beépültek a lamellák közé a molekula méretét HyperChem 7.0 molekula-modellező (PM3) szemiempérikus számolással is számítottam, melynek során az x, y és z koordinátákra 6,399; 0,010 és 8,483 nm értkeket kaptam.

Az XRD mérések és a PM3 számolás során a kapott KYNA molekula méreteit összehasonlítva a molekulák rétegközi interkalációja során a KYNA molekulák paraffin típusú monoréteg elrendeződést mutatnak a rétegen belül (26. ábra, beszúrt sematikus ábra).

A 27. ábrán láthatóak a kiindulási $\mathrm{LDH}$ és a KYNA, valamint a $\mathrm{Mg} / \mathrm{Al}-\mathrm{LDH}-b a$ interkalált KYNA minták FT-IR spektrumai a szerkezet igazolás szempontjából fontos sávok megjelölésével. A kiindulási LDH spektrumán egy széles abszorpciós sávot figyelhetünk meg $3650-2500 \mathrm{~cm}^{-1}$ 
hullámszám tartományban, mely az interlamelláris vízmolekulák és az LDH-rétegek hidroxilcsoport vegyértékrezgéseinek $\left(v_{\mathrm{OH}}\right)$ tulajdonítható. $\mathrm{Az} 1383 \mathrm{~cm}^{-1}$-es hullámszámnál megjelenő, $\mathrm{a} \mathrm{NO}_{3}{ }^{-}$csoport vegyértékrezgésének tulajdonítható sáv [106] abszorbanciája a KYNA/ LDH kompozit esetén lecsökken, jelezve az interlamelláris $\mathrm{NO}_{3}{ }^{-}$-anionok kicserélődését KYNA molekulákra. A kiindulási KYNA spektrumán a karboxilcsoportban lévő -O-H kötés vegyértékrezgése $3474 \mathrm{~cm}^{-1}$ hullámszámnál figyelhető meg. Továbbá, a $3431 \mathrm{~cm}^{-1}$ hullámszámnál tálálható a kinolin gyürühöz kötött OH-csoportra jellemző csúcs, míg 3076 cm$^{-1}$-nál a kinolin gyürü C-H kötéseinek és 2968 cm ${ }^{1}$-nél megjelenő sáv a benzil- és kinolingyürük $\mathrm{C}=\mathrm{H}$ kötésének vegyértékrezgéseinek tulajdonítható [107]. Az aszimmetrikus és szimmetrikus $\mathrm{COO}^{-}$vegyértékrezgések $1700-1400 \mathrm{~cm}^{-1}$ hullámszám között jelennek meg, az 1631, 1595, 1415 és $1247 \mathrm{~cm}^{-1}$-nél jelentkező sávok pedig rendre a v(C=O), $v_{\mathrm{as}}(\mathrm{COO}), v_{\mathrm{s}}(\mathrm{COO})$ és $v(\mathrm{C}-\mathrm{N})$ vegyértékrezgései [108, 109]. Az interkalációt követően a KYNA/ LDH kompozit spektrumán ezek a jellegzetes COO $^{-}$vegyértékrezgések $(1631,1595,1415,1247$ $\mathrm{cm}^{-1}$-nél) szintén jelen vannak, további megerősítésként szolgálva a KYNA/ LDH kompozit kialakulására.

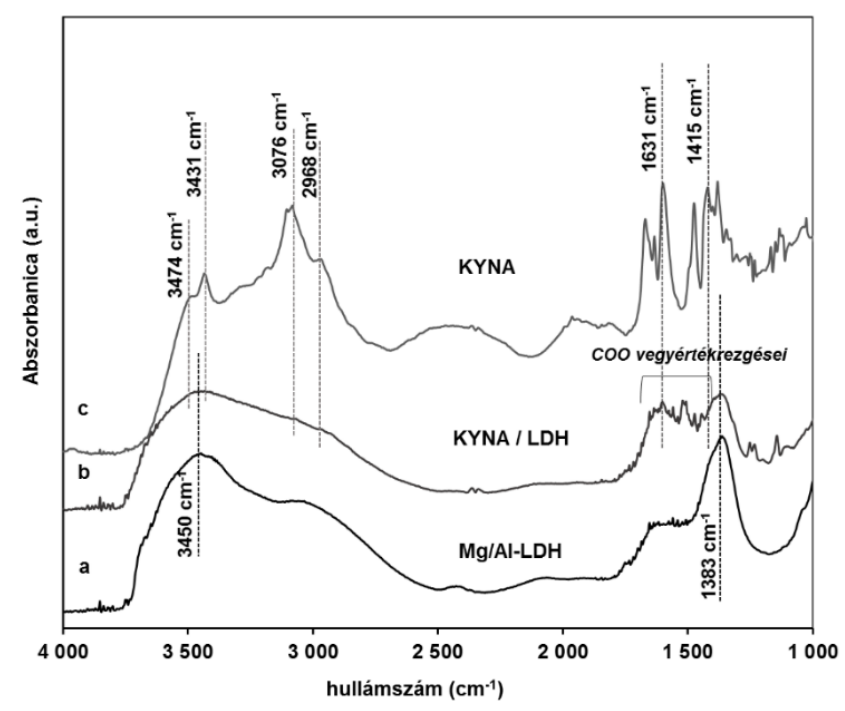

27. ábra. A kiindulási LDH, KYNA és KYNA/ LDH kompozit FT-IR spektrumai.

Az LDH/ KYNA interkalált kompozit szervesanyag tartalmát termoanalitikai mérésekkel is meghatároztam. A 28. ábrán. a kiindulási LDH, valamint a KYNA és KYNA tartalmú LDH minták TG- görbéit tüntettem fel. A szakirodalmi adatok alapján az LDH termikus viselkedését általában két fő szakasz jellemzi: (I) az adszorbeált és az interlamelláris vízvesztésnek köszönhetően kb. 200 ${ }^{\circ} \mathrm{C}$-os tartományig tapsztalható egy reverzibilis és endoterm folyamat, ami a lamelláris szerkezet összeomlása nélkül következik be. A (II) második szakasz, általában 200 és $600-800{ }^{\circ} \mathrm{C}$ közötti hőmérséklet-tartományban fordul elő, és megfelel a lamelláris hidroxilcsoport eltünésének (dehidroxilezésnek) és az anionveszteségnek [110]. 
Ennek megfelelően a kiindulási LDH (vastag vonal) TG görbéjén tömegveszteség figyelhető meg a $25-245^{\circ} \mathrm{C}$ hömérséklet-tartományban, mely a rétegközi víz távozásának köszönhető. A következő szakaszban két jelentős tömegvesztés volt tapasztalható, $245-600{ }^{\circ} \mathrm{C}$ hőmérséklet-tartományban a felületi hidroxilcsoportok távoztak, ill. az $\mathrm{LDH}$ nitrát tartalma $\mathrm{NO}_{2}$ formában távozik. Látható továbbá, hogy a tiszta KYNA hőbomlása 150 és $650{ }^{\circ} \mathrm{C}$ között történt és ezen a hőmérsékleten a szerves KYNA tömegvesztesége teljes volt (szaggatott vonal). A megfelelő TG görbékkel összehasonlítva megállapítható, hogy a KYNA/ LDH kompozit és az LDH minta között fennmaradó tömegkülönbség 13,9 m/m\% volt. A 25. ábrán láthattuk, hogy az LDH lamellák maximális adszorpciós kapacitása körülbelül 120 mg KYNA/ g LDH volt. A termogravimetriás eredmények tehát megerősítették, ill. alátámasztották ezt a 12 m/m\% KYNA-tartalmat.

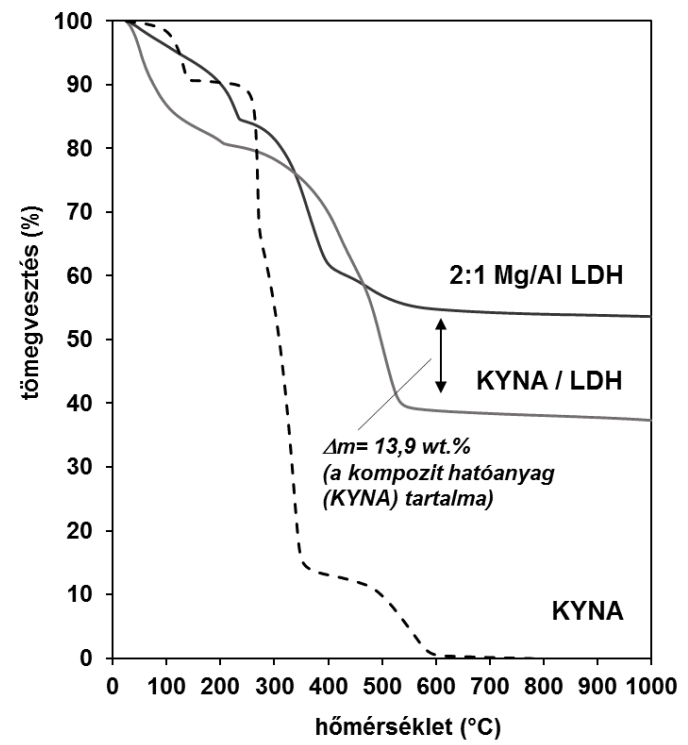

28. ábra. A kiindulási LDH, KYNA és KYNA/ LDH kompozit TG (\%) görbéi. (fütési sebesség: 5 ${ }^{\circ} \mathrm{C} /$ perc).

4.1.3 A KYNA hatóanyag kioldódásának meghatározása az LDH alapú nanohibrid rendszerből gasztrointesztinális körülmények között

A kinurénsav (KYNA) a triptofán anyagcsere terméke, neuroprotektív és fájdalomcsökkentő, gyulladásgátló hatása mellett [111], néhány közlemény a KYNA fekélyellenes (ún. gastroduodenalis (gyomor-patkóbéli) fekélyellenes) tulajdonságáról is beszámol [112, 113].

A biokompatibilis Mg/Al-LDH lehetséges gyógyszerhordozóként lehetővé tenné a KYNA hatóanyag leadását gasztrointesztinális körülmények között, ugyanis kémiai összetételüknek köszönhetően a réteges kettős hidroxidok pH függő oldódási tulajdonságot mutatnak és savas 
körülmények között jelentősen megnő az oldhatóságuk [114]. E tulajdonságukat kihasználva in vitro körülmények között vizsgáltam, hogy a KYNA/ LDH nanokompozit rendszer alkalmas-e pHváltozás indukált hatóanyag leadásra.

Elsőként az LDH oldhatóságát mesterséges gyomornedv (SGF) közegben tanulmányoztam, pH= 1,5 értékén (lásd 3.3.18. fejezet) és az LDH szerkezetváltozását gravimetriás, illetve röntgendiffrakciós mérésekkel vizsgáltam. Az LDH fenti $\mathrm{pH}$ értéken vett oldódási profilját a 29. (a) ábra szemlélteti, melyen megfigyelhető, hogy az LDH oldódása gyors, körülbelül 30 perc elteltével a hordozó anyag 70 \%-a, 6 óra elteltével közel $83 \%$-a oldódik fel.

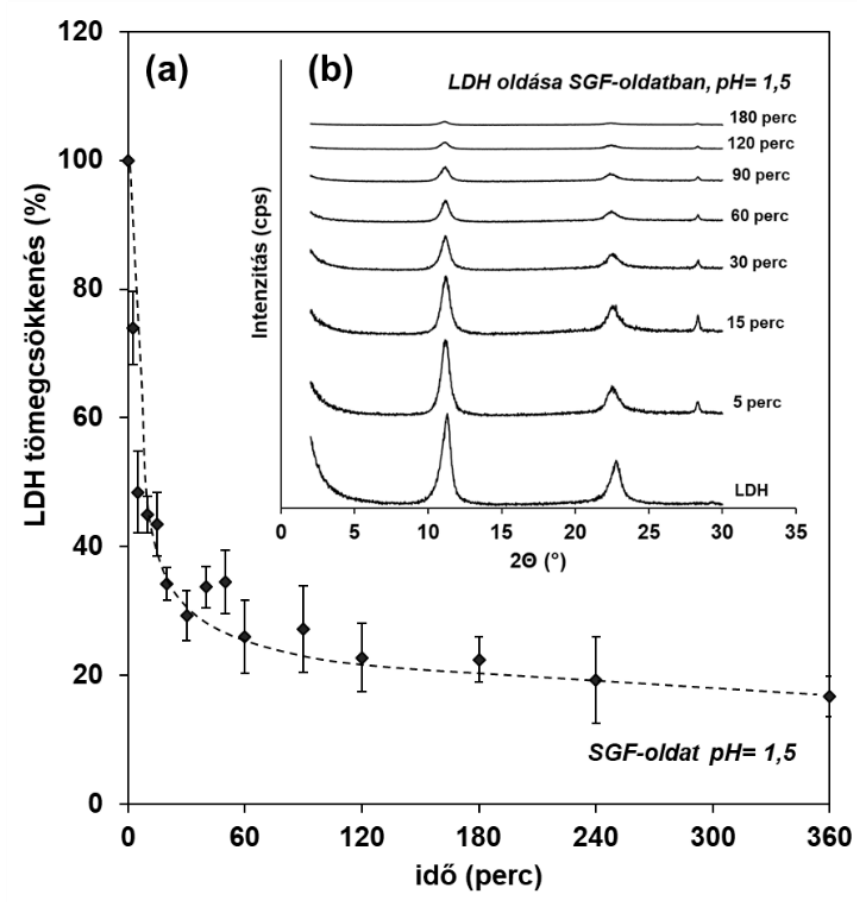

29. ábra. A gravimetriásan (a) és röntgendiffrakciós (b) mérésekkel nyomon követett LDH oldódása szintetikus gyomornedv ( $\mathrm{SGF}$ ) oldatban, $\mathrm{pH}=1,5$ értéken.

Ezzel párhuzamosan a röntgendiffrakciós mérések is alátámasztották, hogy $\mathrm{pH}=1,5$ értékén az oldódásnak köszönhetően az LDH szerkezet szétesik (29. (b) ábra). Megfigyelhető, hogy - az LDH oldódásának köszönhetően - a kezdeti, kristályos LDH-ra jellemző reflexiók $\left(2 \Theta=11,39^{\circ}(003)\right.$ és 22,82-nál (006)) időben csökkenő intenzitást mutatnak a diffraktogramokon.

Ezt követően az LDH rétegei közzé interkalált KYNA hatóanyag kioldódását a száj és a gyomornedv pH értékén ( $\mathrm{pH}=6,70$ [104, 105] és 1,5 [101, 102]) vizsgáltam. A kioldódott hatóanyag koncentrációját spektrofotometriásan határoztam meg a 3.3.19. fejezetben leírtaknak megfelelően. A 30. ábra a hatóanyag-felszabadulási profilokat mutatja be, melyeket testhőmérsékleten $\left(37^{\circ} \mathrm{C}\right)$ és fiziológiás sóoldatban végeztem. Az anionos KYNA oldhatósága és így a kioldódás sebessége a 
pH-tól függ [115], így jelentős különbség látható a KYNA kioldódási profilján (sebességén) pH = 6,70 és 1,50 értéken, ugyanazon kísérleti körülmények között (30. (a) ábra).

(a)

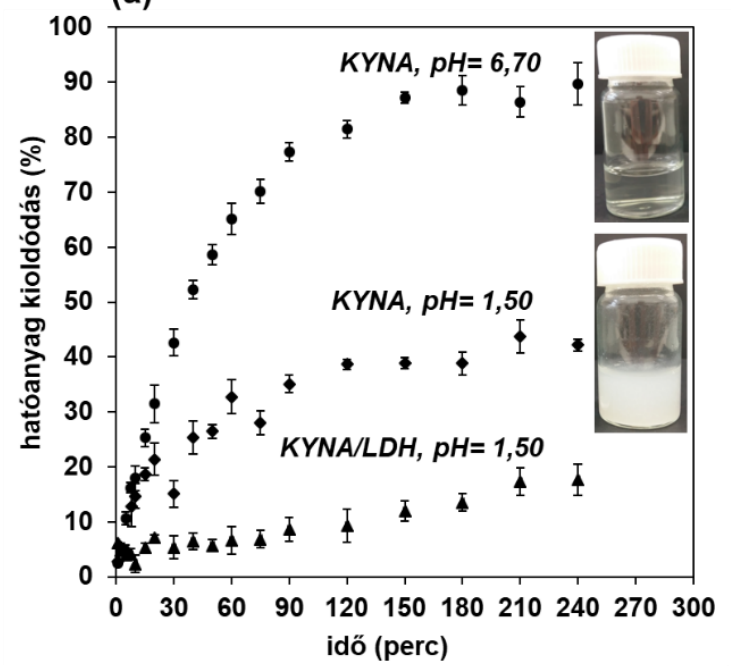

(b)

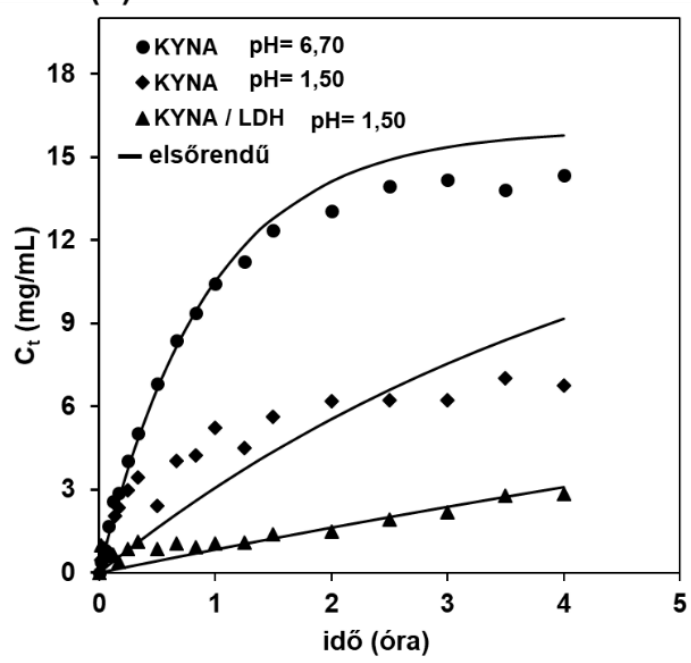

30. ábra. A KYNA hatóanyag százalékos kioldódási profiljai $\left(37^{\circ} \mathrm{C}\right.$-on) különböző $\mathrm{pH}$ értékeken

(a) és az abszolút kiolódást mutató kinetikai görbék az illesztett elsőrendü függvényekkel (b).

A pH függő oldhatósági tulajdonságainak köszönhetően az 1,6 mg/mL koncentrációjú KYNAoldat $\mathrm{pH}=6,70$ értéken egy átlátszó, tiszta oldat, ahogy az a beszúrt fotón is látható (30. (a) ábra), míg $\mathrm{pH}=1,50$ a KYNA oldhatósága jóval kisebb és egy zavaros, opálos rendszert eredményez. Ennek köszönhetően a KYNA molekulák $\mathrm{pH}=6,70$ értéken a membránon történő átjutása kétszer gyorsabb, mint $\mathrm{pH}=1,50$-ös értéken. A kioldódott gyógyszer molekulák százalékos mennyisége folyamatosan nőt 180 percig, majd kb. három óra elteltével 90 \%-os hatóanyag felszabadulásnál telítődik a görbe. Savas pH-án, azonban a KYNA kioldódása egyrészt lassabb, másrészt a mért maximálisan kioldódott hatóanyag értéke is csak körülbelül $43 \%$ volt, a korábban ismerettet KYNA heterogéncsapadék képződése miatt.

A különböző hordozókba inkorporált hatóanyagok kioldódási sebességét több folyamat is befolyásol(hat)ja, azonban különböző kinetikai modellekkel a döntő, sebességmeghatározó folyamat meghatározható [116-120]. A KYNA kioldódását három kinetikai modell alkalmazásával jellemztem. A 2. táblázatban foglaltam össze az alkalmazott kinetikai modellekből nyert paramétereket és az egyenletek ,jóságát” (korrelációs koefficienst: $R^{2}$ ), a KYNA és KYNA/ LDH rendszerek esetében ( $\mathrm{pH}=6,70$ és 1,50 értéken). A kinetikai modellek alapján a $\mathrm{KYNA} \mathrm{pH}=6,70$ értéken történő kioldódása, azaz a membránon történő átjutása koncentrációjától függő elsőrendü kinetikával jellemezhető (30. (b) ábrán), amelyet a modell magas $R^{2}(0,9955)$ értéke mutat (2. táblázat). 
2. táblázat. A KYNA kioldódási profiljaira alkalmazott kinetikai modellek alapján kapott

\begin{tabular}{lcccccc} 
& \multicolumn{9}{c}{$\begin{array}{c}K Y N A \\
p H=6,70\end{array}$} & \multicolumn{2}{c}{$\begin{array}{c}K Y N A \\
p H=1,50\end{array}$} & \multicolumn{2}{c}{$\begin{array}{c}K Y N A / L D H \\
p H=1,50\end{array}$} \\
\cline { 2 - 8 } & \multicolumn{2}{c}{$37^{\circ} \mathrm{C}$} & \multicolumn{2}{c}{$37^{\circ} \mathrm{C}$} & \multicolumn{2}{c}{$37^{\circ} \mathrm{C}$} \\
\cline { 2 - 8 } Kinetikai modell & $k$ & $R^{2}$ & $k$ & $R^{2}$ & $k$ & $R^{2}$ \\
\hline Elsörendü $\left(\mathrm{s}^{-1}\right)$ & $4,75 \times 10^{-5}$ & 0,9955 & $5,91 \times 10^{-5}$ & 0,8363 & $1,49 \times 10^{-5}$ & 0,9045 \\
Korsmeyer-Peppas $\left(\mathrm{s}^{-n}\right)$ & $1,62 \times 10^{\circ}$ & 0,9524 & $1,26 \times 10^{\circ}$ & 0,9506 & $1,90 \times 10^{-1}$ & 0,8361 \\
Higuchi $\left(\mathrm{s}^{-1 / 2}\right)$ & $8,88 \times 10^{-3}$ & 0,9389 & $8,51 \times 10^{-1}$ & 0,9261 & $8,57 \times 10^{-1}$ & 0,8467 \\
\hline
\end{tabular}

Az elsőrendủ kinetikai modell alapján kapott elsőrendű sebességi állandó $k$ értéke $4,75 \times 10^{-5} \mathrm{~s}^{-}$ ${ }^{1}$-nek adódott. Ezzel ellentétben az elsőrendű modell nem adott jó illeszkedést $\left(R^{2}=0,8363\right) \mathrm{pH}=$ 1,50 értéken vizsgált KYNA hatóanyagra, mely feltehetően a fentiekben bemutatott rossz oldékonyság, ill. csapadékképződés miatt következhet be. A meghatározott sebességi állandó ebben az esetben $k=5,91 \times 10^{-5} \mathrm{~s}^{-1}$-nek adódott.

A KYNA/ LDH nanokompozit esetében, $\mathrm{pH}=1,50$ értéken, egy fokozatosan növekvő és elnyújtott hatóanyag-kioldódási profilt figyelhetünk meg, mely kb. $18 \%$-os hatóanyag felszabadulást eredményezett 4 óra elteltével (30. (a) ábrán). A KYNA kioldódására az LDH alapú nanokompozitból az elsőrendű sebességi modell adja a legjobb illeszkedést $\left(R^{2}=0,9045\right)(\mathbf{3 0}$. (b) ábrán), a meghatározott sebességi állandó $k=1,49 \times 10^{-5} \mathrm{~s}^{-1}$-nek adódott (2. táblázat).

Megjegyzendő, hogy a Korsmeyer-Peppas modell illesztése során az $n$ diffúziós kitevőre kapott értékek további információt hordoznak $[121,122]$. A KYNA esetében $\mathrm{pH}=6,70$ és 1,50 értéken a diffúziós kitevő $n=0,43$ és 0,38 kapott értéke alapján a hatóanyag kioldódás Fick-féle diffúziót követ. Viszont a KYNA/ LDH kompozit esetén ( $\mathrm{pH}=1,50$ értéknél) ez a modell egyértelmüen mutatja a nem Ficki-féle diffúzió (anomális transzport) megjelenését $(n=0,46)$, ahol a hatóanyag diffúziója és a hordozó eróziója anomális folyamatot eredményez [122].

Az eddigi eredmények arra engednek következtetni, hogy a KYNA hatóanyag a KYNA/ LDH kompozitból történő kioldódásának sebesség meghatározó lépése az alábbi feltételek függvénye lehet: (1) LDH lamellák oldódása; (2) ioncsere reakció a KYNA és az LDH között és (3) a KYNA kioldódási mechanizmusa az LDH rétegekből.

Összefoglalva a kapott eredményeket elmondható, hogy az előállított 2:1 Mg/Al-LDH nagy fajlagos felülettel és pozitív felületi töltéssel rendelkezett és alkalmasnak bizonyult gyógyszerhatóanyag interkalációra (31. ábra). Az előállított KYNA/ LDH nanokompozot kb. 12 m/m\%-os KYNA tartalommal rendelkezett és a „szendvics-szerkezetben” a KYNA paraffinszerü elrendeződést mutatott. A kialakított nanokompozitból a hatóanyag egy késleltett hatóanyag-leadási 
profilt mutatott gasztrointesztinális körülmények között $(\mathrm{pH}=1,5)$, négy óra elteltével $18 \%$ kinurénsav oldódott ki a nanohibrid rendszerböl (31. ábra). Az előnyös tulajdonságainak köszönhetően az LDH mint gyógyszerhordozó rendszer alkalmas lehet hatóanyagok kapszulázására, szállítására és leadására.

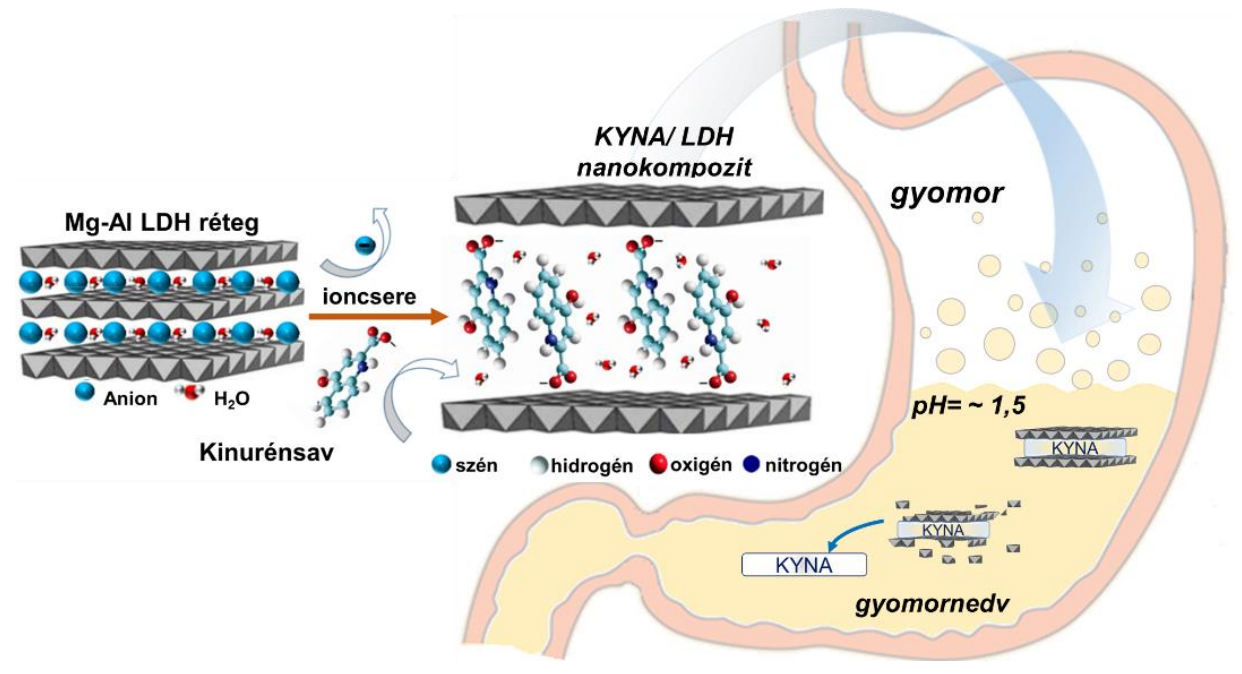

31. ábra. Az LDH rétegek közzé interkalált KYNA hatóanyag és a gyomorba kerülő nanokompozit hatóanyag felszabadulásának sematikus ábrája. 


\subsection{A gömbi morfológiájú LDH és $\mathrm{LDH} / \mathrm{Ag}^{0}$-montmorillonit kompozit jellemzése}

\subsubsection{A gömbi morfológiájú LDH szerkezeti jellemzése}

A ZnMgAl-LDH előállításakor úgynevezett együtt lecsapásos módszert alkalmaztam, mely folyamat lépéseit a 3.2.2.1. pontban mutattam be. A különböző $\mathrm{pH}$ értékeken szintetizált LDH röntgendiffraktogrammjait a 32. ábrán tüntettem fel.

A különböző pH-kon elöállított ZnMgAl-LDH por minták röntgendiffraktogramjain megfigyelhető, hogy $\mathrm{pH}=3$ és 5 körüli értéknél előállított minták esetében az elsődleges reflexió $6,45^{\circ}(2 \Theta)$ szögnél található. Ezek a reflexiók, nagy valószínűséggel a karbamid jelenlétére utalnak. A szintézis során a pH-át eltolva lúgos tartomány felé, ezek a reflexiók eltünnek és megjelennek a réteges szerkezetű LDH mintára jellemző elsődleges és másodlagos reflexiók $2 \Theta=11,629^{\circ}\left(d_{(003)}=\right.$ $0,760 \mathrm{~nm})$, illetve $2 \Theta=23,4^{\circ}\left(d_{(006)}=0,399 \mathrm{~nm}\right)$ szögeknél.

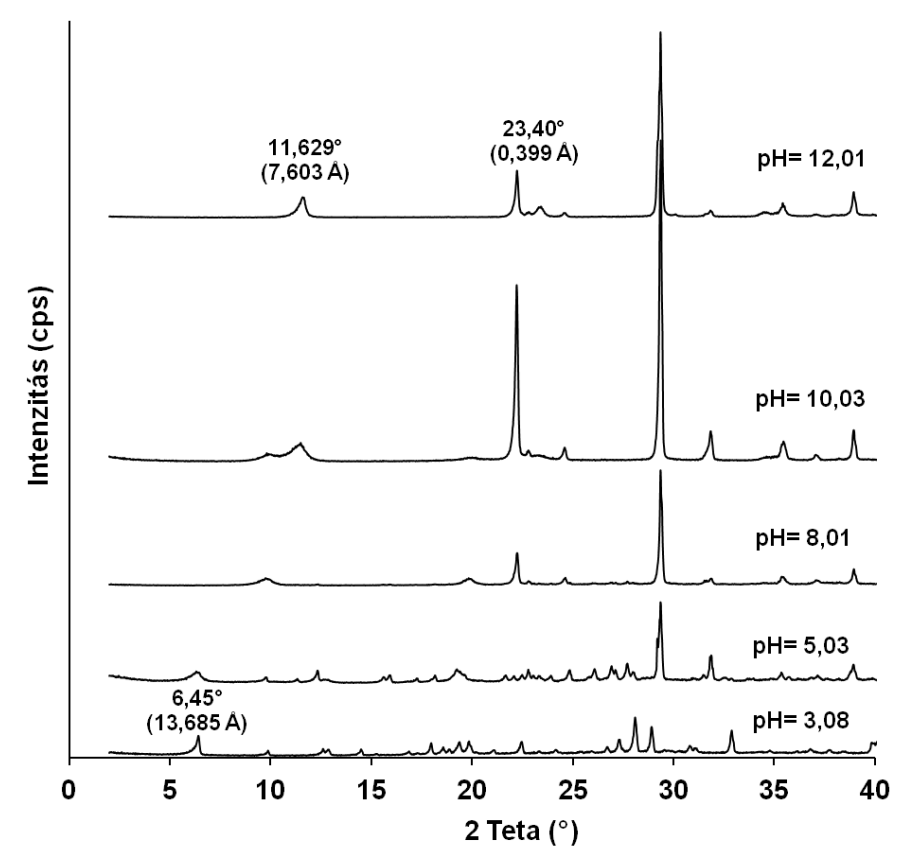

32. ábra. A különböző $\mathrm{pH}$ értékeken (rendre $\mathrm{pH}=3 ; 5 ; 8 ; 10$ és 12) elöállított ZnMgAl-LDH porminták röntgendiffraktogramjai.

Az előállított ZnMgAl-LDH porminták morfológiai változását SEM felvételek rögzítésével követtem nyomon, melyeket a 33. ábra fogalal össze. Összehasonlítva a SEM felvételeket megfigyelhető, hogy a $\mathrm{pH}=3,08$-as értéken (33. (e) ábra) előállított ZnMgAl-LDH mintánál gömb alakú struktúrák kialakulása igazolható, melyek átméröje 23-36 $\mu \mathrm{m}$ között változtak. A szintézisek során alkalmazott közeg pH értékének növekedésével a gömbi morfológia fokozatosan eltünik, és helyette a lamellás szerkezet kialakulása figyelhető meg. 

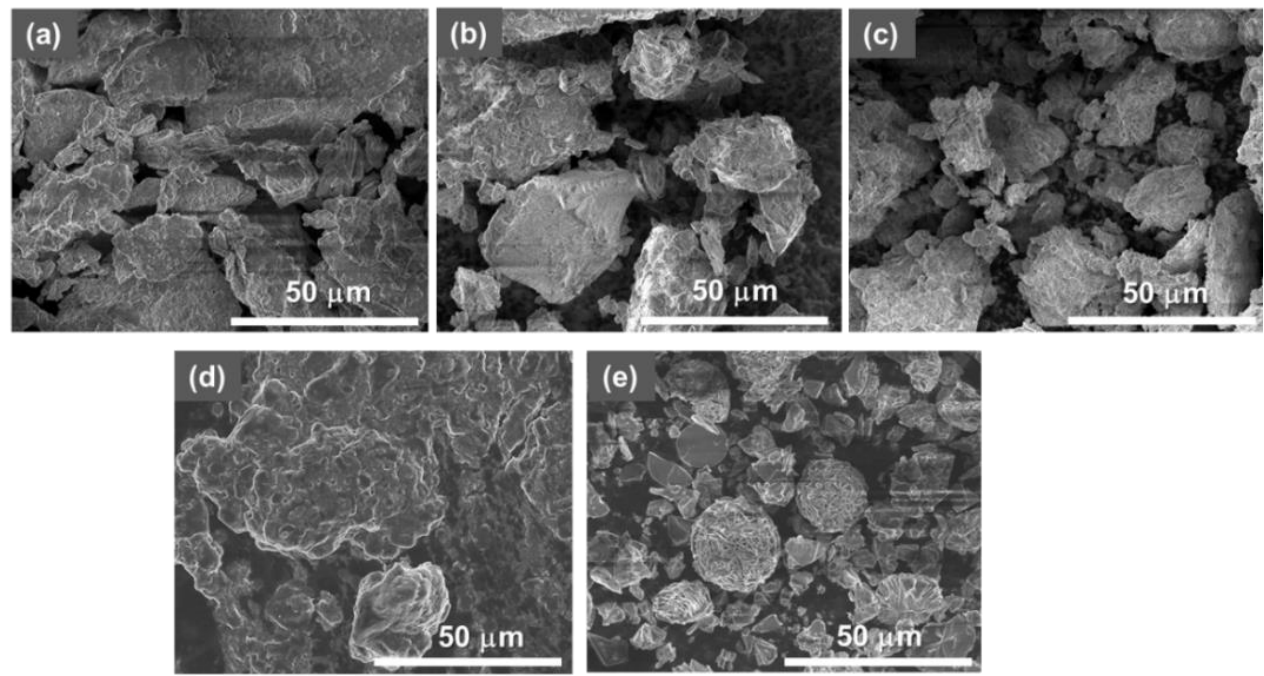

33. ábra. A pH=12,01 (a); 10,03 (b); 8,01 (c); 5,03 (d) és 3,08 (e) értéken előállított ZnMgAlLDH minták példaként bemutatott SEM felvételei.

Az eredmények alapján megállapítható, hogy a karbamid jelenléte fontos a szférikus LDH kialakulásában. Ugyanakkor a rendszer kémhatásának is kulcsfontosságú szerepe van a gömbi alak létrejöttéhez. Szférikus szerkezetü LDH képződésének az lehet az egyik lehetséges magyarázata, hogy alacsony $\mathrm{pH}$ értéken $(\mathrm{pH}=3)$, karbonátos közegben, és magas hömérsékleten a karbamid bomlása során $\mathrm{NH}_{3}$ és $\mathrm{CO}_{2}$ gázbuborékok keletkeznek a rendszerben, melyeken megindul a gócképződés. A lúgos pH értékeken a fenti gázok jobban oldódnak, így a buborékképződés mértéke lecsökken, ezáltel a fenti gócképződési folyamat nem megy végbe.

A fentiekben bemutatott, $\mathrm{pH}=3$-on elöállított $\mathrm{ZnMgAl}-\mathrm{LDH}$ ígéretes eredményeit követően ugyanezen a $\mathrm{pH}$ értéken ismételt szintézist végeztem, figyelemmel kísérve az öregítési idő hatásának szerepét. A 34. ábrán a karbonátos desztillált vízben ( $\mathrm{pH}=3$-as értéken) előállított ZnMgAl-LDH por minták röntgendiffraktogrammjai láthatók, 24, 48 órás és egy hetes öregítési időt követően. Megfigyelhető a 34. ábrán, hogy a ZnMgAl-réteges kettős hidroxidra jellemző (003),

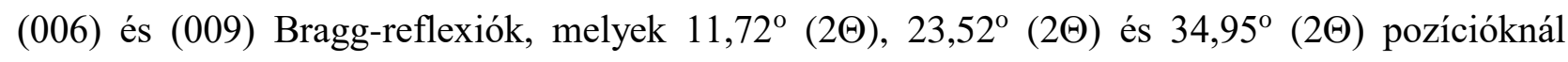
találhatók, az irodalmi adatokkal megegyeznek [37, 38].

Ezek mellett még további jellegzetes reflexiókat is megfigyelhetünk $39,58^{\circ}(2 \Theta), 47,16^{\circ}(2 \Theta)$ és $60,86^{\circ}$ és $62,18^{\circ}(2 \Theta)$ szögeknél, melyek a mintára jellemző (015), (018), (110) és (113) reflexiók [38]. Az is látható, hogy az öregítési idő növekedésével a reflexiók intenzitása, azaz a minták kristályossága is nő. A (003) indexjelű rácssíkhoz rendelhető reflexióból a 4. egyenlet segítségével számított krisztallitok mérete az öregítési idő növekedésével kismértékben nőtt, a 24, 48 óra, ill. az 1 hétig öregített minták esetén ezek a méretek 33,3; 35,2 és 37,6 nm-nek adódtak. 


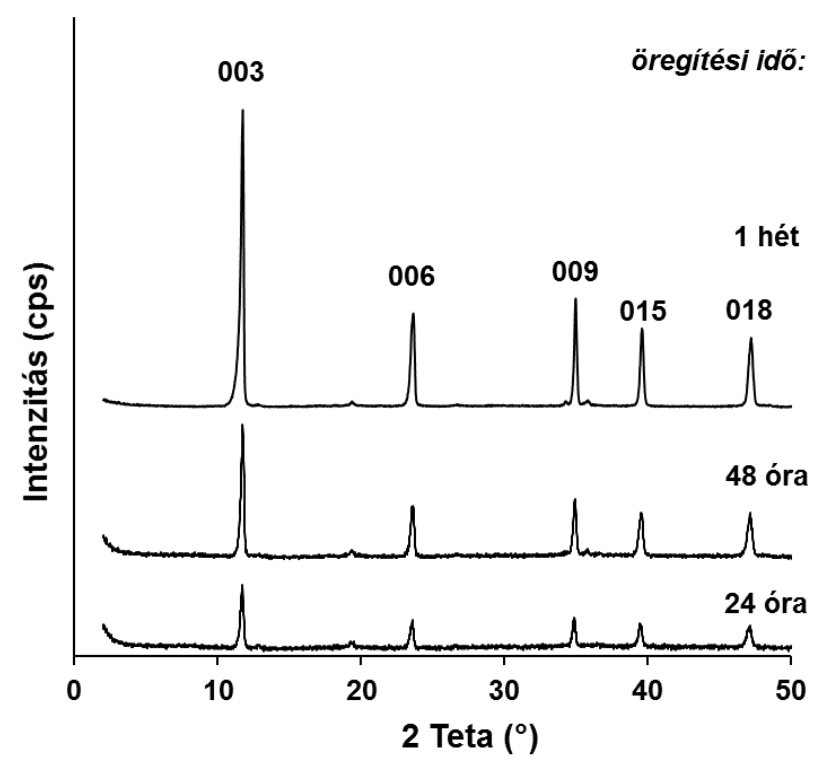

34. ábra. A szintézis (ill. öregítési) idő hatása az előállított gömbi ZnMgAl-LDH porminták röntgendiffraktogramjaira $(\mathrm{pH}=3)$.

A mintákról készített SEM felvételeken (35. ábra) jól látható az LDH mintára jellemző lamellás szerkezet, mely az öregítés hatására és a megfelelő $\mathrm{pH}$ értéken $(\mathrm{pH}=3)$, valamint hőmérsékleten ( $100{ }^{\circ} \mathrm{C}$-on), zárt rendszerben, ,virágszerü” LDH gömbök létrejöttét eredményezte (35. (c) ábra). Összehasonlítva a 24, 48 órás és az 1 hétig öregített LDH mintákat (35. (a), (b) és (c) ábra), megállapítható, hogy az 1 hétig öregített LDH gömbök morfológiája jobban definiált, homogénebb méreteloszlást mutatnak a SEM felvételek alapján (35. és 36. (a) ábra).
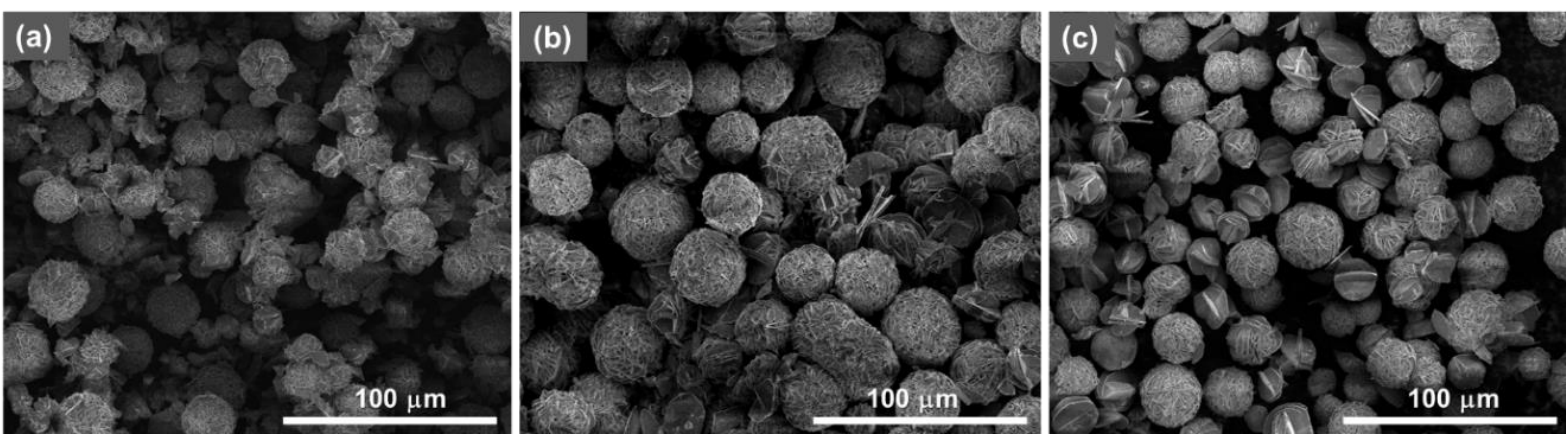

35. ábra. $\mathrm{A} \mathrm{pH}=3$ értéken előállított $\mathrm{ZnMgAl}-\mathrm{LDH}$ minták egy-egy reprezentatív SEM felvételei 24 óra (a), 48 óra (b) és 1 hetes szintézisidő (c) elteltével.

A keletkezett gömbi morfológiájú LDH részecskék méreteloszlási diagramját a 36. (b) ábra szemlélteti és a SEM felvételek alapján meghatározott $\mathrm{LDH}$-ák dsEM $=25,31 \pm 2,34 \mu \mathrm{m}$ átmérővel és a BET mérések alapján 12,84 $\mathrm{m}^{2} / \mathrm{g}$ fajlagos felülettel rendelkeznek. 

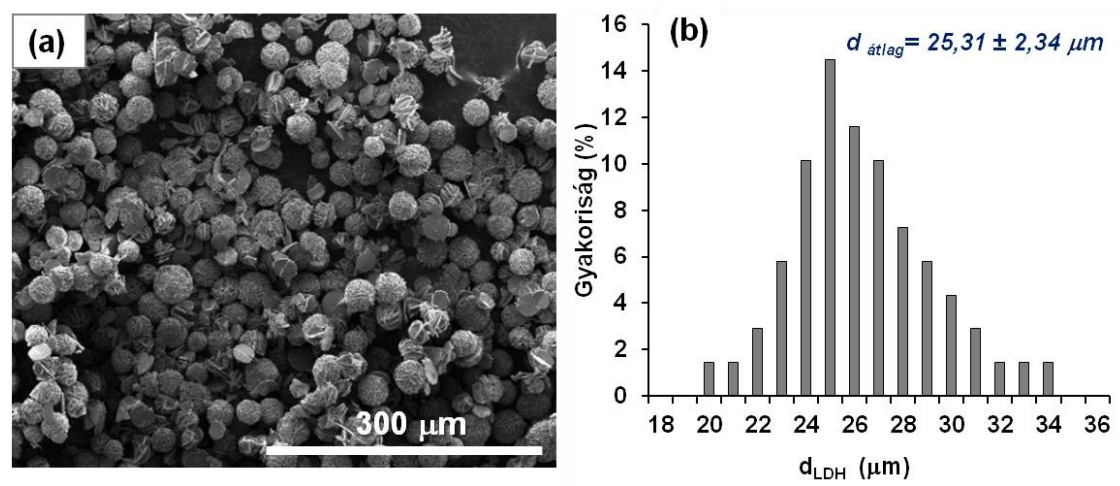

36. ábra. A pH=3-on elöállított 1 hétig öregített $\mathrm{ZnMgAl}-\mathrm{LDH}$ részecskék egy reprezentatív SEM felvétele (a) és a meghatározott méreteloszlási diagram (b).

Az 1 hétig öregített gömbi ZnMgAl-LDH fajlagos töltését különböző $\mathrm{pH}$ értékeken $(\mathrm{pH}=2 ; 3 ; 4$ és 6) határoztam meg a 3.3.3. pontban leírtaknak megfelelően. A 37. (a) ábrán a gömb morfolúgiájú LDH titrálási görbéje látható $\mathrm{pH}=3$-as értéken. A titrálási görbén jól látható, hogy az LDH pozitív áramlási potenciál értéket mutat. A titrálás során a hozzáadott anionos tenzid (NaDS) mennyiségének növekedésével folyamatosan csökkent a mért áramlási potenciál érték. A semleges töltésállapot eléréséig fogyott tenzid mennyiségekből meghatároztam a minta fajlagos töltését, mely $\mathrm{pH}=3$-as értéken 36,41 mmol/ 100g-nak adódott.
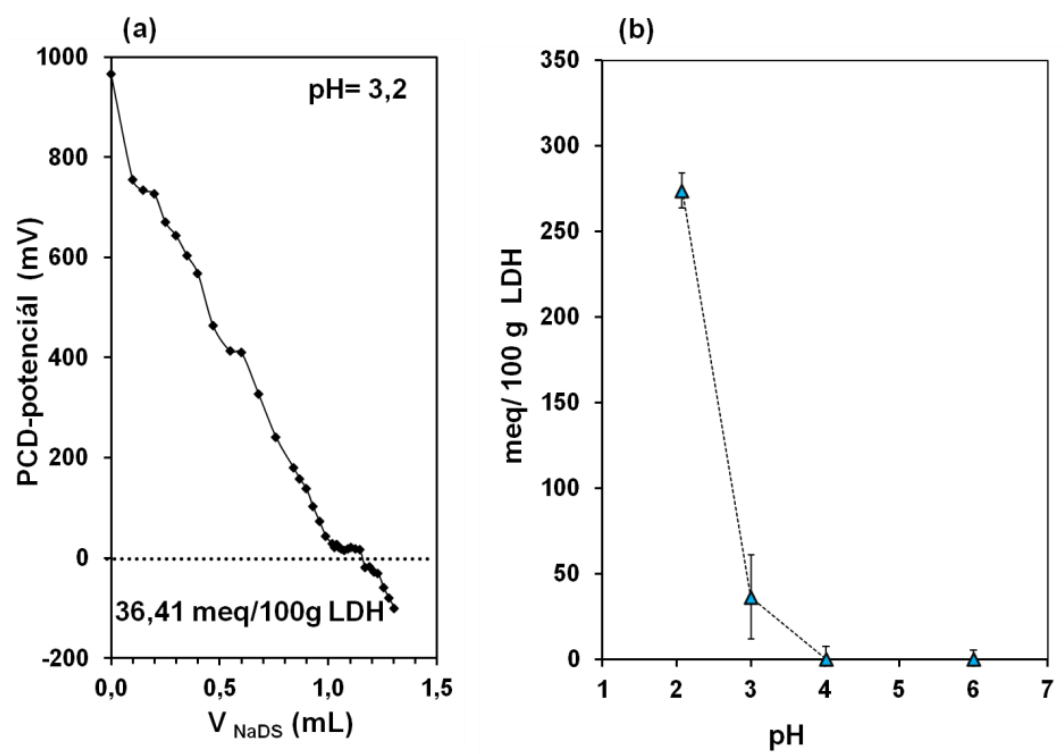

37. ábra. Az 1 hétig öregített gömbi morfológiájú LDH fajlagos töltés értékének meghatározása $\mathrm{pH}=3$ értéken áramlási potenciál mérés (a) segítségével és fajlagos töltésmennyiségének alakulása a $\mathrm{pH}$ változásával (b).

A fentiekkel analóg módon eltérő pH értékeken is meghatároztam az LDH fajlagos töltés értékeit, a kapott értékeket a pH függvényében ábrázoltam (37. (b) ábra). Jól látható, hogy a gömbi morfológiájú ZnMgAl-LDH alacsony $\mathrm{pH}$ értékeknél $(\mathrm{pH}=2$ és 3) igen nagy fajlagos töltéssel rendelkezik (273,94 mmol/ 100g és 36,41 mmol/100g), míg magasabb pH értékeknél (pH=4 és 6) 
ez az érték lecsökken szinte $\sim 0 \mathrm{mmol} / 100 \mathrm{~g}$ értékig, vagyis ezeken a $\mathrm{pH}$ értékeken gyakorlatilag az LDH elveszíti pozitív töltését.

Irodalmi adatok alapján ez a jelenség az oldatban lévő $\mathrm{H}^{+}$ill. $\mathrm{OH}^{-}$ionok $\mathrm{LDH}$ felületére történő adszorpciójával értelmezhető [123]. Alacsony pH értékeknél $(\mathrm{pH}<4)$ az LDH felületén (LDH(s)) lévő OH-csoportok protonálódnak:

$$
\mathrm{LDH}(\mathrm{s})-\mathrm{OH}+\mathrm{H}_{3} \mathrm{O}^{+} \rightarrow \mathrm{LDH}-\mathrm{OH}_{2}{ }^{+}+\mathrm{H}_{2} \mathrm{O}
$$

Magasabb pH értékeknél ( $\mathrm{pH}>4)$ az LDH elveszíti töltését, illetve a pH további növelésével elérhető, hogy a felületén lévő OH-csoportok deprotonálódnak:

$$
\mathrm{LDH}(\mathrm{s})-\mathrm{OH}+\mathrm{OH}^{-} \rightarrow \mathrm{LDH}_{-} \mathrm{O}^{-}+\mathrm{H}_{2} \mathrm{O}
$$

\subsubsection{Gömbi morfológiájú $\mathrm{LDH} \mathrm{Ag}^{0}$-montmorillonittal alkotott kompozit jellemzése}

Ellentétes felületi töltéseken alapuló heterokoagulációs kompozit kialakítása érdekében a változó felületi töltéssel rendelkező LDH-t montmorillonitot negatív felülelti töltéssel rendelkező agyagásvány lamellákkal társítottam ( $\mathrm{pH}=3-6$ tartományon) [124].

A montmorillonit alapú agyagásványok fizikai-kémiai sajátságainak köszönhetően rendkívül széles területen alkalmazhatók (pl. mezőgazdaság, borászat, könnyüipar, kozmetikai ipar, stb.), mint például fertőtlenítés, tixotróp anyagok, szuszpendálószerek, stabilizátorok, töltőanyagok. Munkám

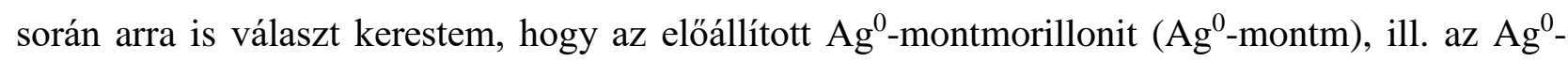
montm. és gömbi LDH vizes közegü szuszpenziója milyen reológiai tulajdonságokkal rendelkezik, ez ugyanis megszabja a minták felhasználási lehetőségeit. Ehhez 25/75 m/m\% összetétellel rendelkező $\mathrm{LDH} / \mathrm{Ag}^{0}$-montm. szuszpenziókat készítettem a 3.2.7. fejezetben leírtak szerint és meghatároztam azok folyásgörbéit (nyírófeszültség ( $\tau$ ) vs. nyírássebesség gradiens (D) függvényeket) a $\mathrm{pH}$ függvényében ( $\mathrm{pH}=3 ; 4,5 ; 5$ és 6). A 38. ábrán a kiindulási Na-montmorillonit (Na-montm), $\mathrm{Ag}^{0}$-montm. és a $25 / 75 \mathrm{~m} / \mathrm{m} \%$ összetételü $\mathrm{LDH} / \mathrm{Ag}^{0}$-montm. szuszpenzió folyásgörbéi láthatók $\mathrm{pH}=3$-as és 6 -os értéken.

$\mathrm{Az} \mathrm{Ag}^{0}$-montmorillonit és a 25/75 m/m\%-os összetételü LDH/ $\mathrm{Ag}^{0}$-montm. szuszpenziók pH= 6-os értéken meghatározott folyásgörbéje newtoni (ideálisan viszkózus) tulajdonságokat mutatott. Ugyanezen a pH értéken a kiindulási Na-montm. folyásgörbéje alapján pszeudoplasztikus viselkedés igazolható (38. (b) ábra). 
A pH csökkenésével, a Na-montm. és $\mathrm{Ag}^{0}$-montm. szuszpenziók nem mutatnak jelentős változást a pH= 6-os értéken meghatározott folyásgörbékhez képest (38. (a) ábra).

(a)

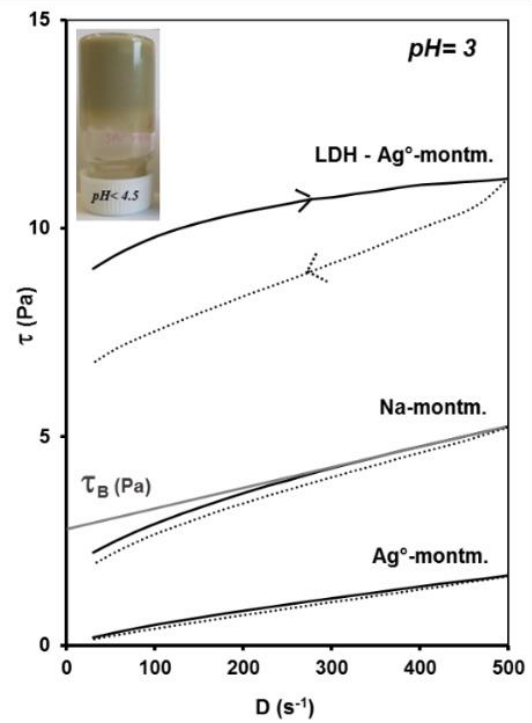

(b)

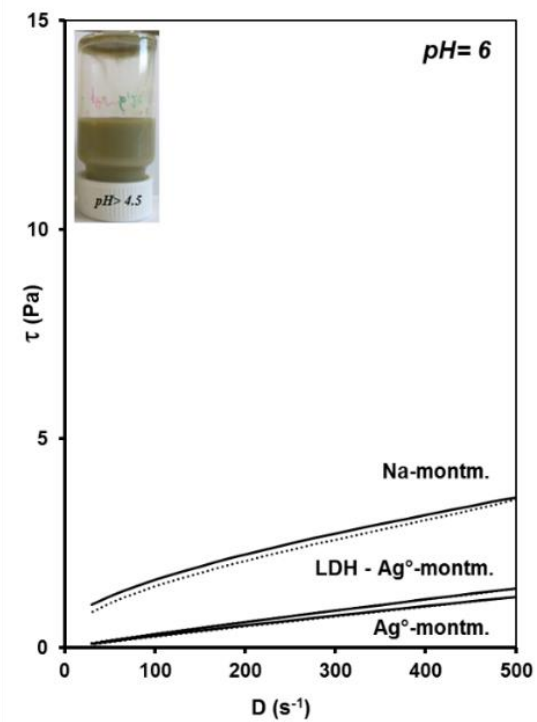

38. ábra. A kiindulási Na-montmorillonit, ill. $\mathrm{Ag}^{0}$-montmorillonit és a $25: 75(\mathrm{~m} / \mathrm{m} \%)$ arányú $\mathrm{LDH} / \mathrm{Ag}^{0}$-montm. minták folyásgörbéi $\mathrm{pH}=3$-as (a) és 6-os (b) értékek mellett.

Ezzel ellentétben az $\mathrm{LDH} / \mathrm{Ag}^{0}$-montm. minta esetén változás tapasztalható; míg $\mathrm{pH}=6$ 6-os értéken a newtoni tulajdonságot, $\mathrm{pH}=3$ értéken pszeudoplasztikus viselkedést mutat (38. (a) ábra). A 38. ábrába beszúrt $\mathrm{LDH} / \mathrm{Ag}^{0}$-montm. mintákról készült fotók is azt szemléltetik, hogy a kompozit rendszer $\mathrm{pH}=3$-as értéken koherens gélként, $\mathrm{pH}=6$-os értéken pedig kis viszkozitású szolként viselkedik.

A vizsgált rendszerek folyáshatár értékeit $\left(\tau_{\mathrm{B}}\right)$ a folyásgörbékre interpolált egyenesek metszéspontjaiból határoztam meg és azokat a 39. ábrán a pH függvényében ábrázoltam.

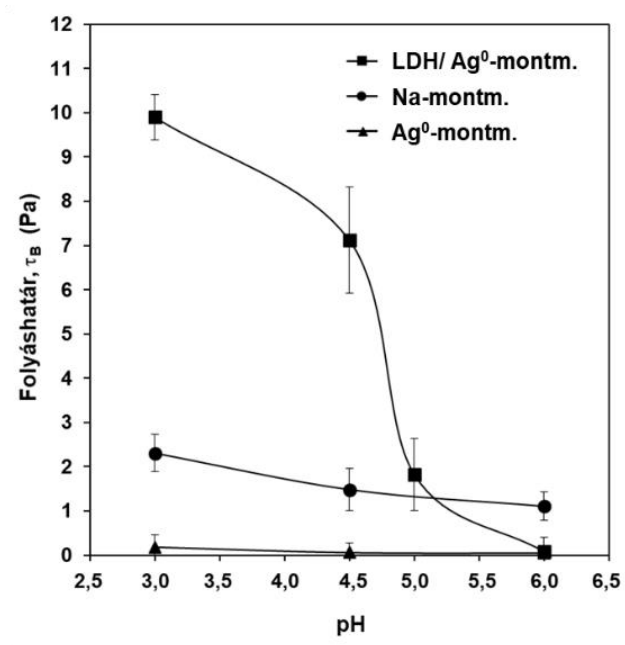

39. ábra. A folyáshatár értékek alakulása a pH függvényében a Na-montmorillonit, $\mathrm{az} \mathrm{Ag}^{0}$ montmorillonit és a 25:75 (m/m\%) arányú $\mathrm{LDH} / \mathrm{Ag}^{0}$-mont. minták esetén. 
Az LDH/ $\mathrm{Ag}^{0}$-montm. kompozitra, ill. az $\mathrm{Ag}^{0}$-montm. és Na-montm. minták esetén meghatározott folyáshatár értékek 0 és $1,1 \mathrm{~Pa}$ között változott $\left(\tau_{\mathrm{B}}=0,08 ; 0,05\right.$ és $\left.1,109 \mathrm{~Pa}\right) \mathrm{pH}=6$ os értéken. A pH-át csökkentve ezek az értékek közel százszorosára nőttek. pH=3-as értéken az $\mathrm{Ag}^{0}$-montm. és Na-montm. minták esetén meghatározott folyáshatár értékek $\tau_{\mathrm{B}}=0,184$ és 2,307 Pa, míg a legnagyobb változást a $\mathrm{LDH} / \mathrm{Ag}^{0}$-montm. kompozitra kaptam, mely esetben a $\tau_{\mathrm{B}}=9,90 \mathrm{~Pa}-$ nak adódott. Ez a nagymértékü változás is azzal magyarázható, hogy a $\mathrm{pH}=3$-on tanulmányozott LDH/ $\mathrm{Ag}^{0}$-montm. rendszer gélként viselkedik, annak köszönhetően, hogy a vizsgált pH értéken a gömbi LDH pozitív felületi töltéssel rendelkezik, mely kompenzálja a negatív felületi töltéssel rendelkező $\mathrm{Ag}^{0}$-montm. lamellákat, létrehozva így egy heterokoagulált szerkezetet.

A közeg pH értékének emelésével, a gömbi morfológiájú LDH elveszíti pozitív felületi töltését (lásd 37. ábra), ennek következtében a gélszerkezet szétesik és folyékony kolloid szolként viselkedik, melynek folyásgörbéje a newtoni folyadékokhoz hasonlít.

A minták pH-függő szerkezeti jellemzőit kisszögü röntgenszórással (SAXS) is vizsgáltuk. A 25/75 m/m\% -os LDH/ $\mathrm{Ag}^{0}$-morillonit minták különböző pH-értékeken felvett szórásigörbéit a 40. ábra szemlélteti.

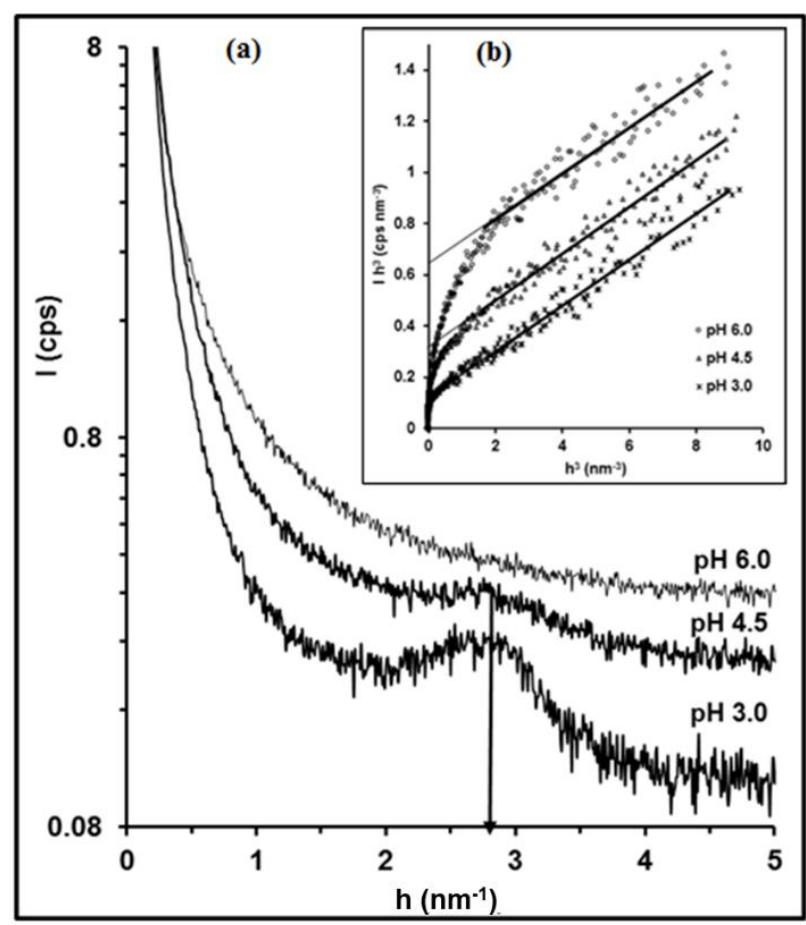

40. ábra. A $25 / 75 \mathrm{~m} / \mathrm{m} \% \mathrm{LDH} / \mathrm{Ag}^{0}$-montmorillonit szórásgörbéi $\mathrm{pH}=3 ; 4,5$ és 6-os értéken (a) és a minták szórásgörbéinek Porod féle reprezentációja (b).

Megfigyelhető, hogy a pH csökkenésével párhuzamosan a $\mathrm{h}=2,94 \mathrm{~nm}^{-1}$-nél egy jellemző csúcs jelenik meg (40. (a) ábra), mely az $\mathrm{LDH} / \mathrm{Ag}^{0}$-montmorillonit $\mathrm{pH}=3$-as értéken kialakult 
szerkezetre utal. A gélképzés során $(\mathrm{pH}: 6 \rightarrow 3)$ a felület felszíni fraktál dimenziója 3,36-ról 2,59re csökkent (3. táblázat), jelezve a heterokoagulációs jelenség által okozott felületi strukturáltság növekedését, emellett a tömeg fraktál dimenzió növekedése (2,26-ról 2,41-re) megerösíti, a rendszer tömörödését, más szóval, a laza, folyadékszerkezet egyre rendezettebbé válik. Ezt megerősíti a Porod-diagram elemzése is (40. (b) ábra), amely rávilágít arra, hogy a pH változtatásával (csökkenésével) az LDH/ $\mathrm{Ag}^{0}$-montmorillonit esetén a Porod konstans értéke változik, $\mathrm{K}_{\mathrm{p}}=0,66$ cps $/ \mathrm{nm}^{3}$-ről $0,13 \mathrm{cps} / \mathrm{nm}^{-3}$-re csökken, továbbá a belső specifikus felülettel szorosan összefüggő $\mathrm{K}_{\mathrm{p}} / \mathrm{Q}$ érték is csökkent (3. táblázat) a gélesedés következtében.

3. táblázat. A Na-montm., $\mathrm{Ag}^{0}$-montm. és $\mathrm{LDH} / \mathrm{Ag}^{0}$-montm. minták kisszögü röntgenszórás (SAXS) mérésekböl meghatározott tömeg fraktál $\left(\operatorname{Dim}_{m}\right)$, felület fraktál $\left(\operatorname{Dim}_{\mathrm{s}}\right)$, Porod-konstans $\left(K_{p}\right)$ és $K_{p} / Q$ (belső specifikus felülettel arányos $S / V$ ) értékek.

\begin{tabular}{ccccccccc}
\hline \multirow{2}{*}{ Minták } & \multicolumn{2}{c}{ Dim $_{\mathrm{m}}$} & \multicolumn{2}{c}{ Dim $_{\mathrm{S}}$} & \multicolumn{2}{c}{$\mathrm{K}_{\mathrm{p}}\left(\mathrm{cps} \mathrm{nm}^{-3}\right)$} & \multicolumn{2}{c}{$\mathrm{K}_{\mathrm{p}} / \mathrm{Q}\left(\mathrm{nm}^{2} / \mathrm{nm}^{3}\right)$} \\
& $p H=3,0$ & $p H=6,0$ & $p H=3,0$ & $p H=6,0$ & $p H=3,0$ & $p H=6,0$ & $p H=3,0$ & $p H=6,0$ \\
\hline Na-montm. & 1,35 & 1,34 & 3,30 & 3,26 & 1,40 & 1,34 & 0,18 & 0,25 \\
$\mathrm{Ag}^{0}$-montm. & 2,01 & 2,26 & 3,49 & 3,45 & 1,33 & 1,37 & 0,23 & 0,25 \\
LDH/ $\mathrm{Ag}^{0}$-montm. & 2,41 & 2,26 & 2,59 & 3,36 & 0,13 & 0,66 & 0,06 & 0,19 \\
\hline
\end{tabular}

4.2.3 $\mathrm{Az} \mathrm{LDH} / \mathrm{Ag}^{0}$-montmorillonit kompozitok pH-függő antibakteriális tulajdonsága

A kiindulási Na-montm. és az előállított rétegközi $\mathrm{Ag}^{0}$ nanorészecskéket tartalmazó montmorillonit $\left(\mathrm{Ag}^{0}\right.$-montm.) minták szerkezetvizsgálatára röntgendiffrakciós méréseket végeztem (41. ábra).

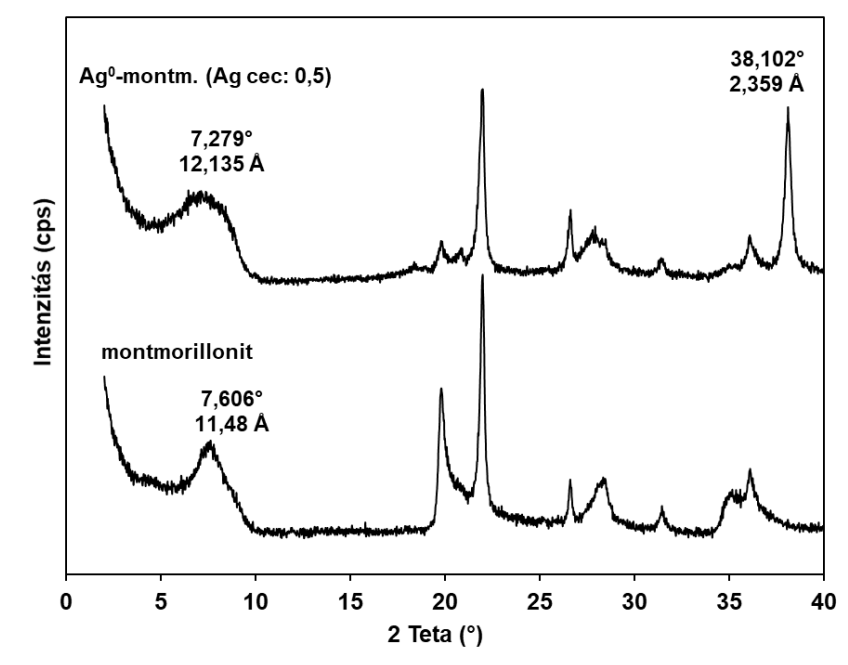

41. ábra. A kiindulási Na-montm. és $\mathrm{Ag}^{0}$-montm. porminták röntgendiffraktogramjai. 
A 41. ábrán az alsó diffraktogramm a kiindulási Na-montm., még a felső az $\mathrm{Ag}^{0}$-montm.-hoz

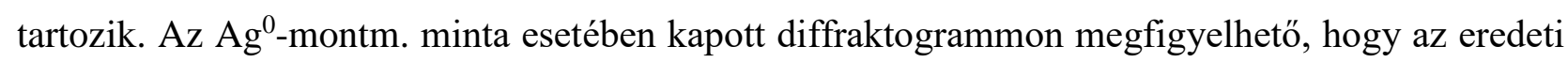
montmorillonitra jellemző reflexió $2 \Theta=7,606^{\circ}$ szögnél $(11,48 \AA$ bázislap-távolság) eltolódik a kisebb szögtartomány felé $2 \Theta=7,279^{\circ}$, mely $12,135 \AA$ d bázislap-távolságnak felel meg, jelezvén az $\mathrm{Ag}^{0}$ részecskék interkalációját a hordozó rétegei közzé. Ugyanakkor az $\mathrm{Ag}^{0}$-montm. esetében

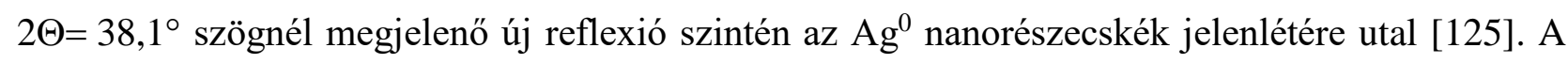
montmorillonit rétegek között kialakuló $\mathrm{Ag}^{0}$ nanorészecskék jelenlétét abszorbancia mérésekkel is bizonyítottam. Ennek során meghatároztam a kiindulási 0,025 (m/V)\%-os koncentrációjú montmorillonit és az előállított $\mathrm{Ag}^{0}$-montm. diszperziók abszorbciós spektrumát, melyek a 42. ábrán láthatók. Összehasonlítva a Na-montm. és $\mathrm{Ag}^{0}$-montm. abszorbancia spektrumokat jól látható, hogy az $\mathrm{Ag}^{0}$-montm. minta esetén egy jól definiált plazmon sáv $\lambda_{\max }=400 \mathrm{~nm}$ hullámhossznál detektálható, mely a montmorillonit lamellákon immobilizált gömb alakú $\mathrm{Ag}^{0}$ nanorészecskék jelenlétére utal.

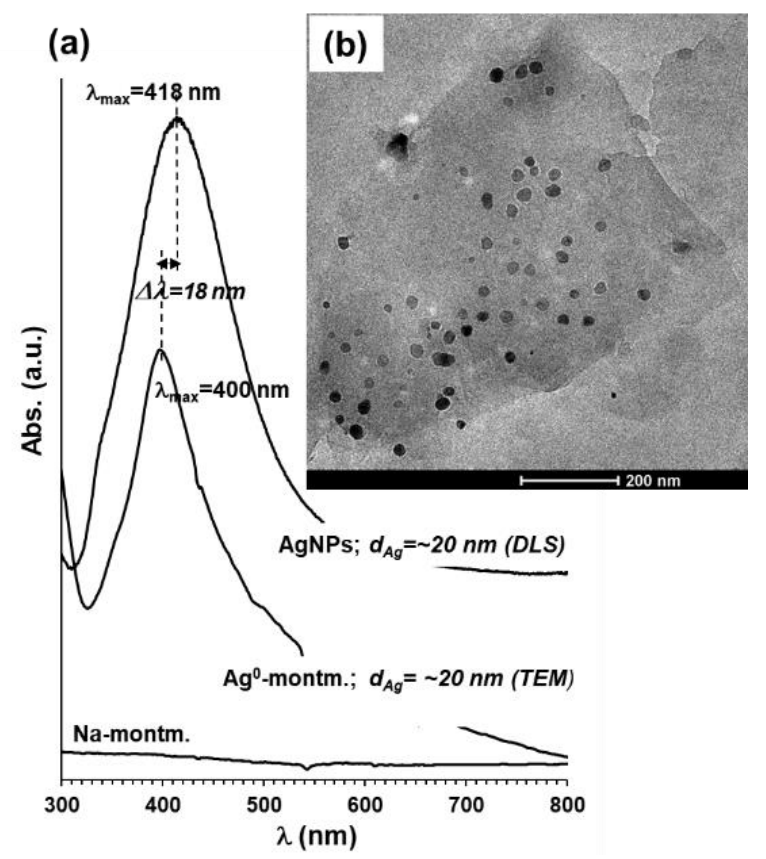

42. ábra. A Na-montm., $\mathrm{Ag}^{0}$-montm. és $\mathrm{Ag}^{0}$-szol (AgNPs) minták UV-VIS spektruma (a), valamint az $\mathrm{Ag}^{0}$-montm.-ról készített reprezentatív TEM felvétel (b).

A TEM felvételek alapján, a montm. lamellákon immobilizált $\mathrm{Ag}^{0}$-nanorészecskék átméröjére átlagosan $\mathrm{dTEM}=21,9 \pm 2,96 \mathrm{~nm}$-nek adódott (42. (b) ábra). A referenciaként előállított $\mathrm{Ag}^{0}$ nanorészecskék (AgNPs) abszorbancia spektrumát is feltüntetve, egy $\Delta \lambda=18 \mathrm{~nm}$-es eltolódás volt megfigyelhető az $\mathrm{Ag}^{0}$-szol minta esetén $\left(\lambda_{\max }=418 \mathrm{~nm}\right)$ és a DLS vizsgálatokból meghatározott AgNPs részecskék átlagos hidrodinamikai átmérőjük dDLS $=20,2 \pm 8,34$ nm-nek adódtak. Ez a 
hullámhossz-különbség $(\Delta \lambda=18 \mathrm{~nm})$ és az $\mathrm{Ag}^{0}$-montm. szükebb abszorpciós csúcsa a monodiszperz részecskék eloszlásának köszönhető a tiszta AgNPs-hez képest.

A 4.2.2. fejezetben láthattuk, hogy ha a gömbi morfológiájú LDH mintához állandó felületi töltéssel rendelkező $\mathrm{Ag}^{0}$-nanorészecskéket tartalmazó montmorillonitot adunk, a kapott rendszerek viszkozitása nagyban függ a diszpergáló közeg pH értékétől. Ebből kiindulva a fenti rendszer alkalmazható szabályozott hatóanyag leadására, ui. alacsony $\mathrm{pH}$ értékeken $(<4,5)$ a rendszer gélként, még magasabb pH értékeken (> 4,5) szolként viselkedik (43. ábra). A közeg pH értékének növekedésével az LDH gömbök elveszítik felületi pozitív töltésüket, mely hatására a gélszerkezet megbomlik, a rendszer viszkozitása lecsökken, így az antibakteriális tulajdonságokkal rendelkező $\mathrm{Ag}^{0}$-montm. [126] a környezetbe juthat, és ott kifejthetik baktérium-, ill. gombaölő tulajdonságát.

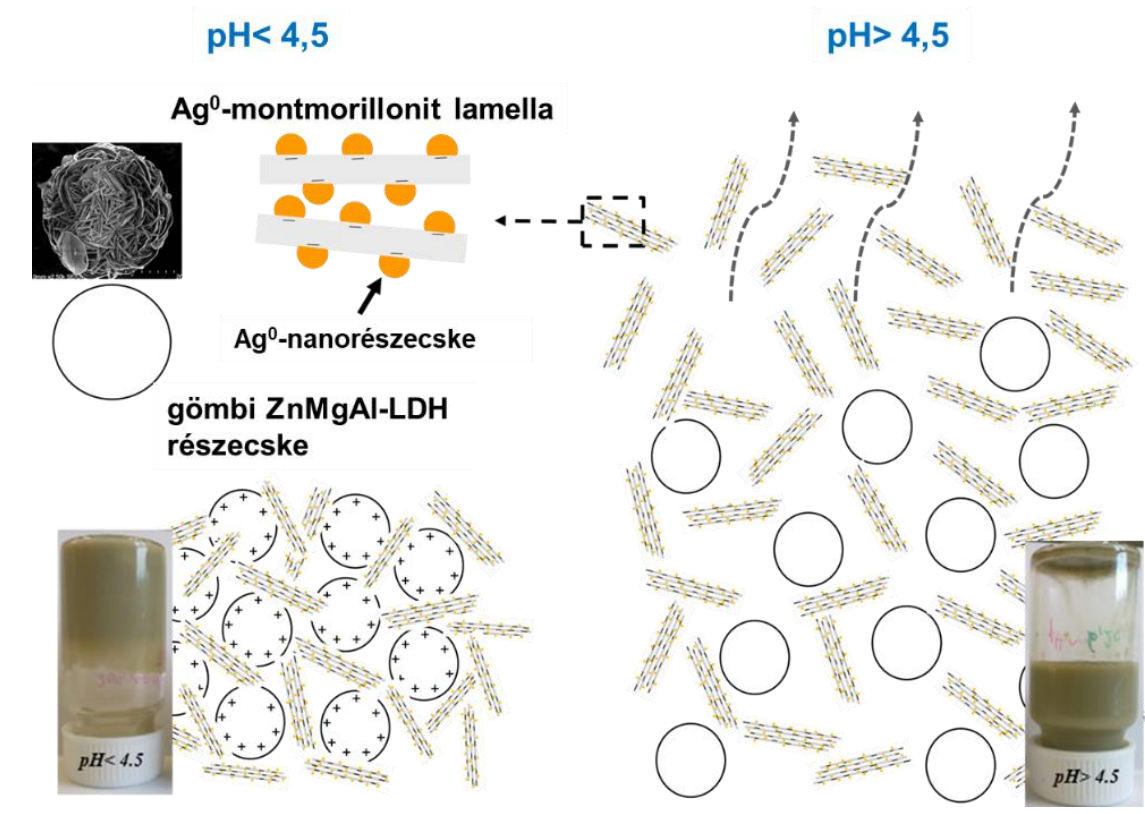

43. ábra. A pH-függő szerkezeti tulajdonságokat mutató $(25 / 75 \mathrm{~m} / \mathrm{m} \%) \mathrm{LDH} / \mathrm{Ag}^{0}$ montmorillonit kompozit szol-gél állapotának sematikus ábrája és a rendszerek fotója.

A fentiek alapján pH-függő szerkezettel rendelkező LDH/ $\mathrm{Ag}^{0}$-montmorillonit kompozit rendszer alkalmas rá, hogy a $\mathrm{pH}$ növelésével a széteső szerkezet hatására az antibakteriális tulajdonságokkal rendelkező AgNPs hozzáférhetősége megnőjjön. Ennek igazolására membránon át történő „kioldódási” teszteket végeztem $\mathrm{pH}=3$ és 6 értékeken. A kísérletben alkalmazott Franzcella membránján átjutott minta spektrofotometriás vizsgálata során az $\operatorname{AgNPs}(\lambda=400 \mathrm{~nm})$ lokalizált felületi plazmonrezonancia sávja adott lehetőséget.

A 44. ábrán bemutatott mérési eredményekből látható, hogy $\mathrm{pH}=3$-as értéken az $\mathrm{LDH} / \mathrm{Ag}^{0}$ montmorillonit minta koherens gélként történő viselkedése miatt nem jut át a cella membránján, még a pH értéket eltolva lúgosabb (=6) tartományba, a gél elfolyósodik, azaz a viszkozitása lecsökkent (44. ábra) és az $\mathrm{Ag}^{0}$-montmorillonit közel $100 \%$-a átjut a membránon. 
Az eredmények megerősítették, hogy az ilyen típusú rendszerek hatékonyan alkalmazhatók szabályozott hatóanyag leadásra olyan helyeken, ahol a pH valamilyen elváltozás következtében (fertőzés, gyulladás, stb.) enyhén savas $(\mathrm{pH}<4,5)$ értékröl lúgosra $(\mathrm{pH}>4,5)$ változik.

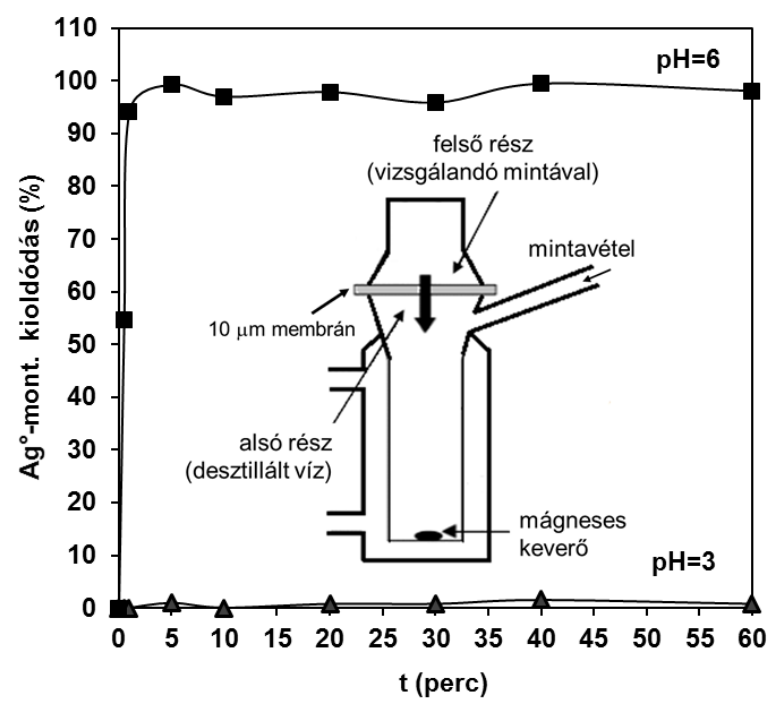

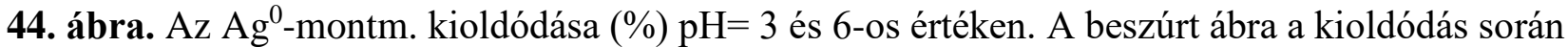
alkalmazott Franz-cella sematikus ábráját mutatja.

$\mathrm{Az} \mathrm{Ag}^{0}$-nanorészecskék antibakteriális hatása a szakirodalomban jól ismert [127], és reméltük, hogy az $\mathrm{Ag}^{0}$-montmorillonit hasonló eredményeket mutat. Ebből kifolyólag különböző koncentrációjú $\mathrm{Ag}^{0}$-montm. vizes diszperziókat készítve, vizsgáltuk azok antibakteriális tulajdonságát is az Escherichia coli (ATCC 29522) baktériumfilmeken, melynek átlagos felületi baktérium koncentrációja $1,79 \times 10^{6} \mathrm{CFU} / \mathrm{cm}^{2}$ volt (45. ábra).

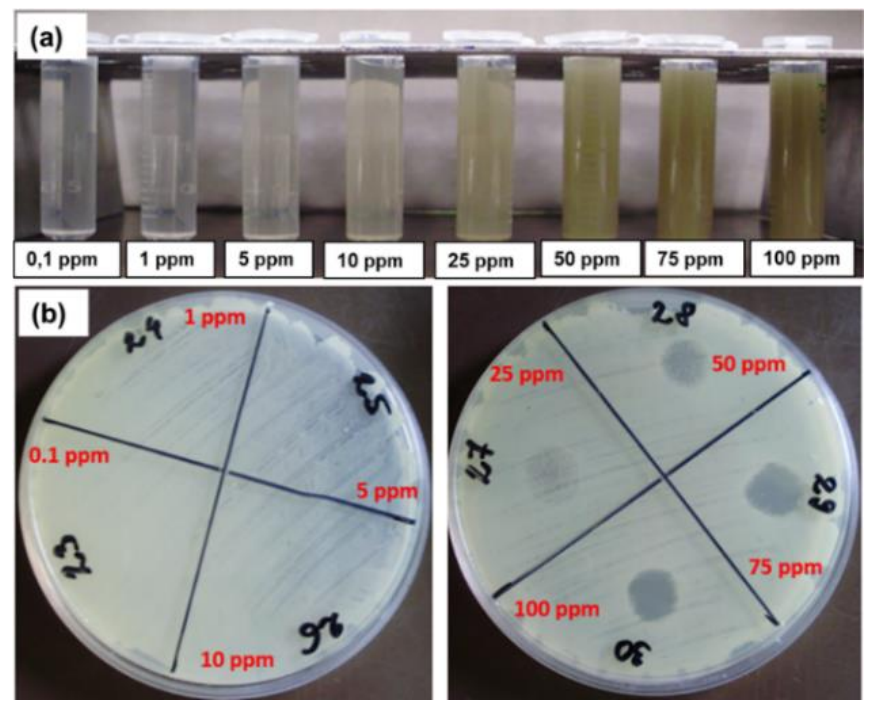

45. ábra. A különböző koncentrációjú $\mathrm{Ag}^{0}$-montmorillonit szuszpenziók fotója (a) és szuszpenzók antibakteriális hatását igazoló fotók (b) az Escherichia coli baktérium filmeken jelentkező feltisztulási zónákról. 
Az alkalmazott $\mathrm{Ag}^{0}$-montm. szuszpenzió koncentrációk 0,1 és 100 ppm között változott (45. (a) ábra) és a kísérlet során megjelenő feltisztulási/ gátlási zónák (45. (b) ábra) információt adnak arra vonatkozóan, hogy mely minimális koncentrációjú $\mathrm{Ag}^{0}$-montm. szuszpenziótól fejt ki antibakteriális hatást az Escherichia coli baktériumokkal szemben. Az eredményekből jól látható, hogy már 25 ppm koncentrációjú $\mathrm{Ag}^{0}$-montm. szuszpenzió alkalmazása mellett megjelenik a gátlási zóna és ezek a zónák egyre hangsúlyosabbá válnak az $\mathrm{Ag}^{0}$-montm. koncentráció növekedésével.

Figyelembe véve az $\mathrm{Ag}^{0}$-montm. térfogatát $(30 \mu \mathrm{l})$ ill. koncentrációját $(25 \mathrm{ppm})$ és az Escherichia coli baktériumfilm felületi koncentrációját $\left(1,79 \times 10^{6} \mathrm{CFU} / \mathrm{cm}^{2}\right)$, elmondható, hogy az alkalmazott $\mathrm{Ag}^{0}$-montm. specifikus antibakteriális felületi koncentrációja 3,14 × $10^{9} \mathrm{CFU}$ E. coli/ mg $\mathrm{Ag}^{0}$-montm.-nak adódik. 


\subsection{A gömbi morfológiájú LDO és LDO/ p(PFDAk) polimer kompozitok jellemzése}

A 3.2.2.2. fejezetben leírtak szerint sikerült viszonylag monodiszperz; gömbi morfológiával rendelkező kb. $25 \mu \mathrm{m}$-es $\mathrm{LDH}$ részecskéket előállítani, ahol a hagyományos hatszögletü LDH lamellák radiálisan helyezkednek el. Ennek a kialakult morfológiának köszönhetően, az előállított LDH részecskék érdes, strukturált felülettel rendelkeztek. Az előállított LDH mintát egy $600{ }^{\circ} \mathrm{C}$-os kalcinálást követően eredméynesen állítottam elö ZnMgAl- réteges kettős oxidot (LDO). Kihasználva az előállított LDO részecskék fizikai és kémiai tulajdonságát, olyan bifunkciós vékonyrétegek preparálása is célja volt munkámnak, melyek egyszerre mutathatnak szuperhidrofób és fotoreaktív tulajdonságokat.

\subsubsection{A gömbi morfológiájú LDO szerkezeti jellemzése}

ZnMgAl-réteges kettős oxid (LDO) előállítását egy $600{ }^{\circ} \mathrm{C}$-os hőkezeléssel értem el ZnMgAlréteges kettős hidroxidból kiindulva (3.2.3. fejezet). A 46. (a) ábrán a kiindulási ZnMgAl-LDH minta és a kalcinálást követően kapott ZnMgAl-LDO porminták diffraktogramjai láthatók. A kalcinálást követően az LDH-ra jellemző Bragg-reflexiók (az elsődleges reflexiók 2 $\Theta=11,63^{\circ}$ $\left(\mathrm{d}_{(003)}=0,760 \mathrm{~nm}\right)$ és másodlagos reflexiók $2 \Theta=23,4^{\circ}$ szögnél $\left(\mathrm{d}_{(006)}=0,399 \mathrm{~nm}\right)$ [37]) eltünnek és új reflexiók jelennek meg $30^{\circ}$ és $60^{\circ}(2 \Theta)$ között, melyek az LDO mintára jellemzőek.

(a)

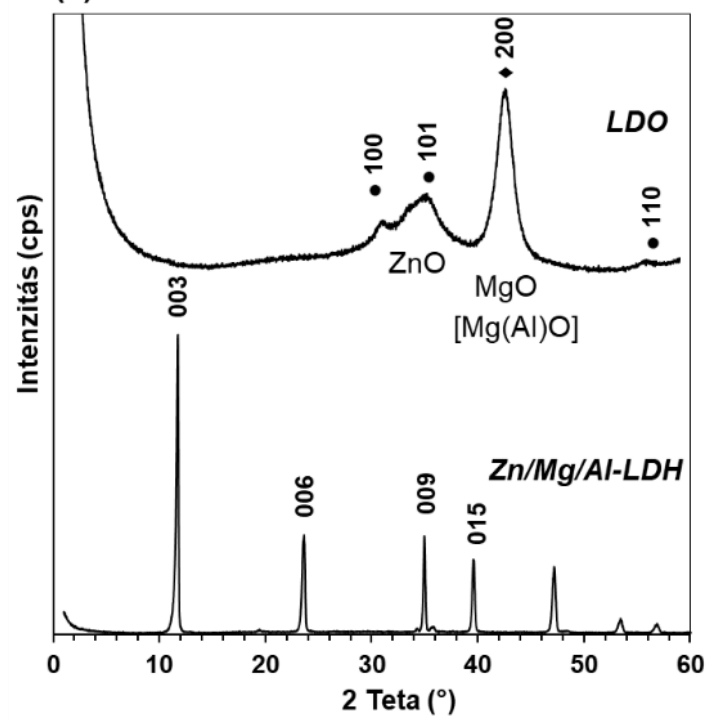

(b)

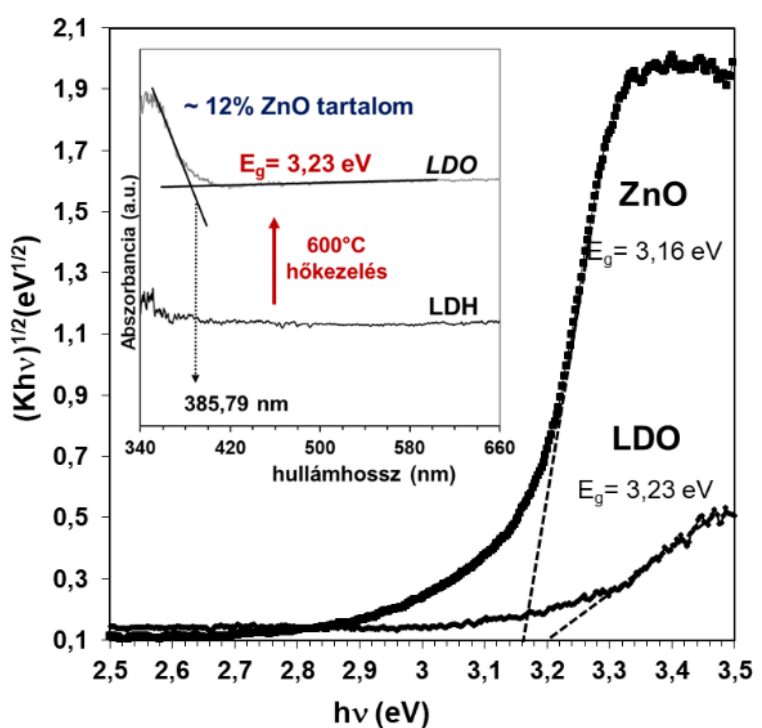

46. ábra. Az előállított gömbi morfológiájú ZnMgAl-LDH és LDO porminták diffraktogramjai (a), valamint diffúz-reflexiós spektrumai (b, beszúrt ábra) és az LDO és ZnO (Nanox, mint referencia) diffúz-reflexiós méréseiből, Kubelka-Munk módszer alapján számított gerjesztési küszöbenergia $(E g)$ értékek (b). 
A $2 \Theta=43,60^{\circ}$ szögnél jelentkező (200) Bragg-reflexió az LDO szerkezetében jelenlévő MgO ( $\mathrm{Mg}(\mathrm{Al}) \mathrm{O})$ fázis képződésére utal (JCPDS 45-0946) [128]. A $2 \Theta=32,02^{\circ} ; 36,28^{\circ}$ és 56,67 szögeknél jelentkező reflexiók a ZnO-ra jellemző [129] (100), (101) és (110) Bragg-reflexiók jelenlétéről adnak információt (JCPDS 36-1451).

Az XRD mérések alapján megállapítható (46. (a) ábra), hogy a kalcinálási folyamat következtében az LDH minták kezdeti cink-hidroxidtartalma ZnO-á alakul, mely lehetőséget teremt UV-fénnyel gerjeszthető félvezető fotokatalizátor előállítására, mely szerkezetéből adódóan érdes felülettel is rendelkezik [89, 130].

Az előállított LDO fotokatalizátor minta gerjesztési küszöbenergia $\left(E_{g}\right)$ értékét az előzetesen meghatározott diffúz-reflexiós spektrum (46. (b) beszúrt ábra) alapján, Kubelka-Munk módszerrel határoztam meg. Az 46. (b) ábra az LDO minta és a kereskedelmi forgalomban kapható $~ 50 \mathrm{~nm}$ es félvezető $\mathrm{ZnO}$ (Nanox, mint referencia) fotokatalizátor Kubelka-Munk- reprezentációját mutatja be. Köszönhetöen annak, hogy az LDO $12 \mathrm{~m} / \mathrm{m} \%$-ban ZnO fázist tartalmaz, a meghatározott gerjesztési küszöbenergia értéke 3,23 eV, még a referencia $\mathrm{ZnO}$ (Nanox) minta $E_{g}$ értéke 3,19 eV volt. A meghatározott $E_{g}$ értékek az irodalmi adatokkal jó egyezést mutattak a $\mathrm{ZnO}$ fotokatalizátorra vonatkozóan [131].

A kezdeti LDH minta strukturált gömbi morfológiája a $600{ }^{\circ} \mathrm{C}$-os kalcinálást követően nem változott, a SEM felvételek alapján, a kapott LDO-részecskék megtartották eredeti gömbi alakjukat és strukturált, radiálisan elhelyezkedő lamellás szerkezetüket (47. ábra). Fajlagos felületük kis mértékben nőtt $\left(14,75 \mathrm{~m}^{2} / \mathrm{g}\right)$ a kiindulási LDH-hoz képest $\left(12,84 \mathrm{~m}^{2} / \mathrm{g}\right)$.
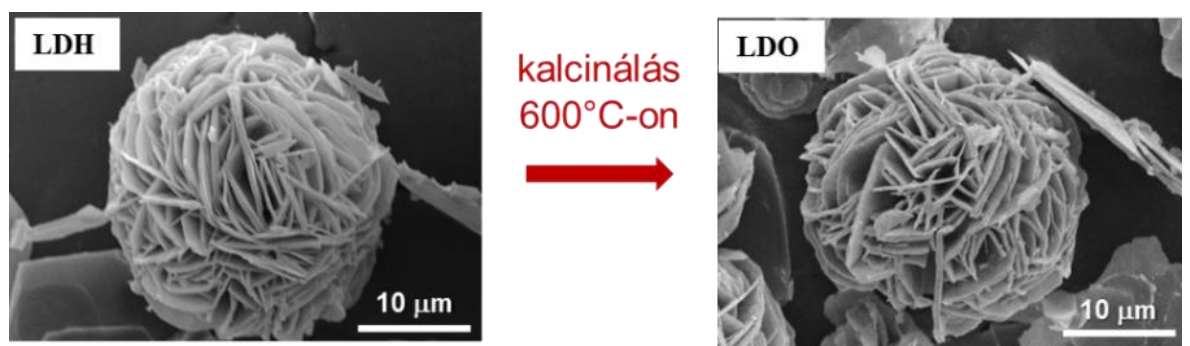

47. ábra. A kiindulási LDH és a kalcinálást követő LDO részecskék SEM felvételei. 


\subsubsection{Az LDO/ p(PFDAk) polimer kompozit filmek tulajdonságai}

A szuperhidrofób jelleg nemcsak a felület kémiai összetételtől, hanem a felület geometriájától, morfológiájától is nagyban függ. Szuperhidrofób felület előállításához alacsony felületi energiára és érdes felület együttes jelenlétére van szükség. Az érdes felületet az LDO részecskék biztosítják, de a hidrofób jelleg kialakításához kis energiájú p(PFDAk) fluoropolimer alkalmazását terveztük. Az alkalmazott makromolekula láncok poliakrilát alapú, fővegyérték láncához perfluorodecil oldalcsoportok kacsolódnak (48. ábra) és a magas fluortartalmának köszönhetően, a polimerböl kialakított vékonyréteg alacsony felületi energiával rendelkezik [60].

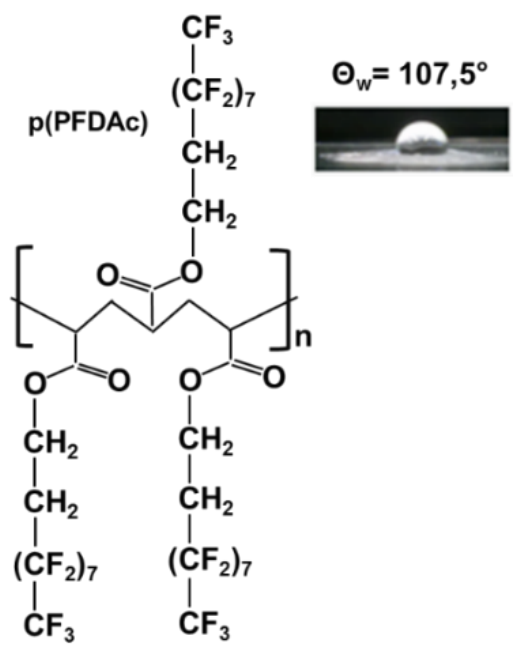

48. ábra. A p(PFDAk) polimer monomeregységének szerkezeti képlete és a fluoropolimer alapú vékonyrétegre cseppenett desztillált víz tesztfolyadék fotója és a mért peremszög érték.

Ezen polimerből kialakított sík felületü vékonyréteg hidrofób tulajdonságokat mutat, ahogyan a 48. ábrán desztillált víz tesztfolyadékra kapott peremszög értéke $\left(\Theta_{\mathrm{w}}=107,5^{\circ}\right)$ is igazol. Ezen érték azonban a célul kitüzött szuperhidrofób felületekre jellemző $\Theta_{\mathrm{w}}=150^{\circ}$-os értéket önmagában nem éri el.

A kis energiájú p(PFDAk) fluoropolimer réteg sík felületét LDO részecskék hozzáadásával érdesítettem (49. (a) ábra), hogy a szuperhidrofób jelleget növelni tudjam (lásd 3.2.9. fejezetben). Az LDO tartalom növelésével, az LDO/ fluoropolimer rétegek egyre strukturáltabb, érdesebb felületi morfológiával rendelkeztek. A SEM felvételek jól szemléltetik, hogy a kiindulási, fluoropolimer réteg viszonylag sima felülettel rendelkezik és az LDO tartalom növekedése (20, 40, 60 és $80 \mathrm{~m} / \mathrm{m} \%$ ) jelentősen megnöveli a hibrid rétegek felületi érdességét (49. (b) ábra). $100 \mathrm{~m} / \mathrm{m} \%$ részecske tartalomnál (tiszta LDO-réteg) pedig a jól elkülönült, 25 $\mu$ m-es LDO szférikus részecskék láthatók (49. (b) ábra). 

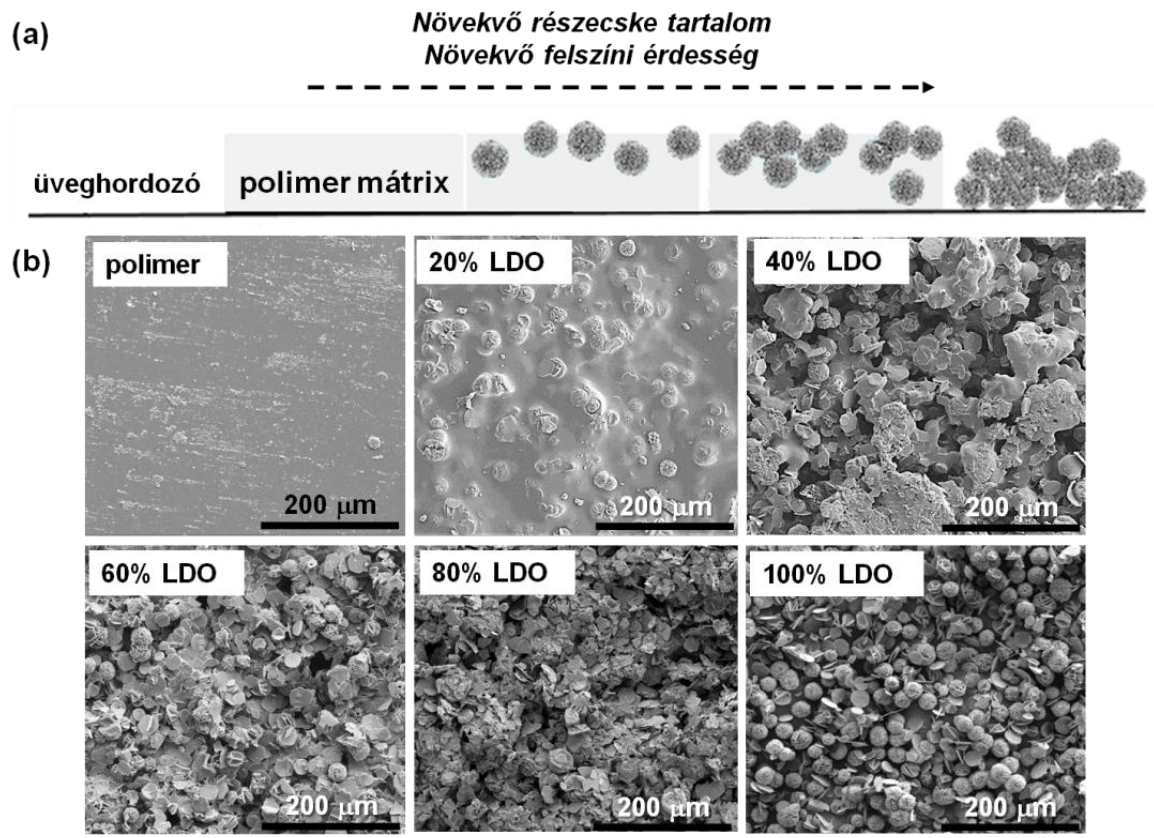

49. ábra. Az LDO/ $\mathrm{p}(\mathrm{PFDAk})$ kompozit rétegek kilakításának sematikus ábrája (a). A kiindulási p(PFDAk) polimer és az egyre növekvő (20, 40, 60, 80 és 100 m/m\%) LDO tartalmú polimer rétegekröl készült reprezentatív SEM felvételek (b).

Az 50. ábra a fluoropolimer alapú LDO tartalmú hibrid rétegek TG görbéit mutatja. A mérések kivitelezése előtt a mintákat (hibrid rétegeket) egy éjszakán $70^{\circ} \mathrm{C}$-on szárítottuk, kivéve a 100 $\mathrm{m} / \mathrm{m} \%$ LDO réteget (szaggatott vonal), hogy eltávolítsuk az adszorbeált vízmolekulákat.

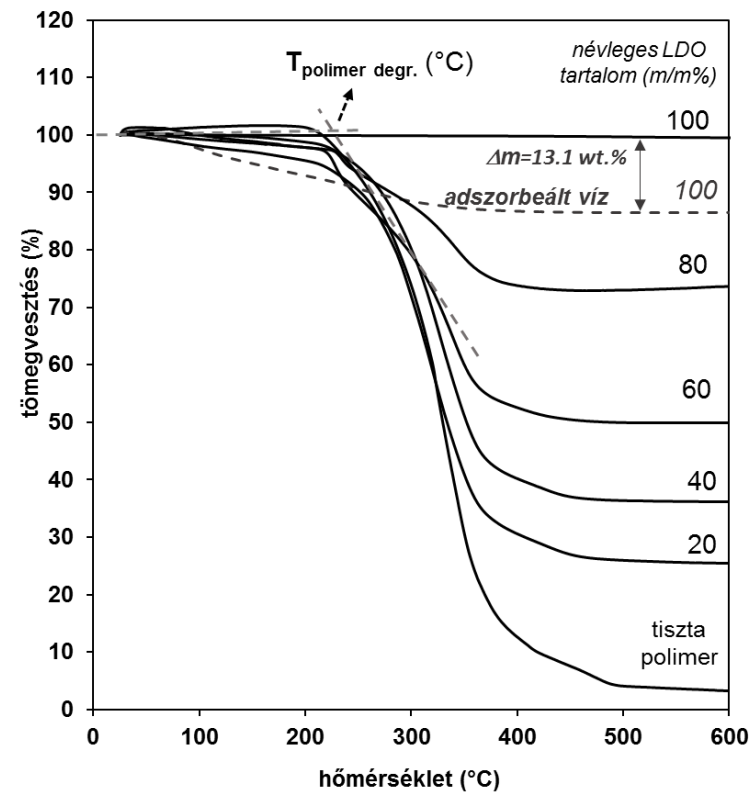

50. ábra. A kiindulási p(PFDAk) polimer és az egyre növekvő LDO tartalmú polimer rétegek TG (\%) görbéi (fütési sebesség: $5^{\circ} \mathrm{C} /$ perc).

Ahogy az látható, a $70{ }^{\circ} \mathrm{C}$-os szárítási eljárásnak kitett polimer mentes szervetlen LDO-minta tömegvesztesége elhanyagolható volt $\left(0,5 \mathrm{~m} / \mathrm{m} \% 600{ }^{\circ} \mathrm{C}\right.$-on); azonban a szárítási eljárás nélkül a 
tömegveszteség 13,1 m/m\%. Ez egyértelmüen az adszorbeált vízmolekuláknak köszönhető, mely az LDO töltőanyag részecskék hidrofil jellegét jelzi. A fluoropolimert tartalmazó kompozit minták TG-görbéin megfigyelhető egy termikus lépcső $\mathrm{T}=200-500{ }^{\circ} \mathrm{C}$ között. Az $500{ }^{\circ} \mathrm{C}$ felett tapasztalt maradék tömeg a kompozit rétegek egyre növekvő szervetlen LDO-tartalmának felel meg. A

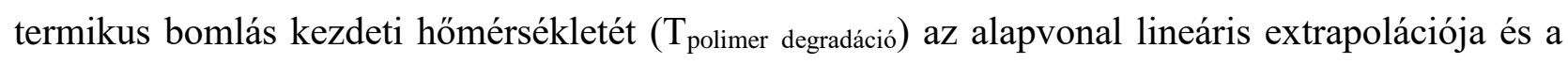
TG görbe meredeksége (tömegvesztési lépcső) közötti metszéspont határozza meg (pontozott vonal az ábrán). Az alacsonyabb LDO-tartalmú hibrid rétegek (20-40 m/m\%) kissé magasabb hőmérsékleten $\left(264,27\right.$ és $\left.259,38^{\circ} \mathrm{C}\right)$ kezdtek lebomlani, mint a tiszta p(PFDAk) $\left(212,73{ }^{\circ} \mathrm{C}\right)$. A 60 és $80 \mathrm{~m} / \mathrm{m} \%$ LDO-tartalmú hibrid rétegek esetében azonban a termikus bomlási hőmérsékletek hasonló értékünek $\left(210,68\right.$ és $\left.216,1^{\circ} \mathrm{C}\right)$ adódtak, mint a kezdeti fluoropolimer $\left(212,73{ }^{\circ} \mathrm{C}\right)$ esetén az megállapítható volt.

Ezek az eredmények azt mutatják, hogy az LDO mikrorészecskék jelenléte -kis koncentrációban- kissé gátolta a fluoropolimer mátrix termikus lebomlását (4. táblázat).

4. táblázat. $\mathrm{Az} \mathrm{LDO} / \mathrm{p}(\mathrm{PFDAk})$ hibrid rétegek névleges és termogravimetriásan meghatározott LDO tartalma, valamint a rétegek számolt porozitása és a meghatározott degradációs hőmérséklet értékek.

\begin{tabular}{|c|c|c|c|c|c|}
\hline Cnévleges LDO (wt.\%) & $\begin{array}{r}\text { cmért LDO } \\
(\text { wt.\% })^{1}\end{array}$ & $\begin{array}{c}\text { dréteg, mért } \\
(\mu \mathrm{m})\end{array}$ & $\begin{array}{c}\text { dréteg, számolt } \\
(\mu \mathbf{m})^{2}\end{array}$ & $\begin{array}{c}\text { porozitás } \\
(\%)^{\mathbf{3}}\end{array}$ & $\begin{array}{c}\text { T }_{\text {degradáció }} \\
\left({ }^{\circ} \mathbf{C}\right)\end{array}$ \\
\hline 0 (fluoropolimer film) & 3,17 & $64 \pm 1,03$ & 52,8 & 17,5 & 212,73 \\
\hline 20 & 25,36 & $125 \pm 1,48$ & 64,5 & 48,4 & 264,27 \\
\hline 40 & 36,06 & $182 \pm 1,33$ & 76,3 & 58,1 & 259,38 \\
\hline 60 & 49,81 & $194 \pm 1,69$ & 88,1 & 54,6 & 210,68 \\
\hline 80 & 73,59 & $197 \pm 1,80$ & 99,8 & 49,3 & 216,09 \\
\hline 100 (LDO réteg) & 99,54 & $201 \pm 1,67$ & 111,5 & 44,5 & - \\
\hline \multicolumn{6}{|c|}{${ }^{1}$ termogravimetrásan meghatárotott } \\
\hline \multirow{2}{*}{\multicolumn{2}{|c|}{${ }^{2} d_{\text {számolt }}=$}} & ${ }_{L D O} \cdot \frac{\mathrm{m}_{\mathrm{LDO}}}{\rho_{\mathrm{LDO}}}+\mathrm{w}_{p c}$ & mer. $: \frac{m_{\text {polimer. }}}{\rho_{\text {polimer. }}}$ & & \\
\hline & & & & & \\
\hline
\end{tabular}

Ahogy azt a 3.2.9. fejezetben bemutattam, ezeket a hibrid rétegeket egyszerü, porlasztásos filmképzéssel állítottam elö. A TG-mérések eredményei alapján a $600{ }^{\circ} \mathrm{C}$-on mért maradék tömegértékek 3,17; 25,36; 36,06; 49,81; 73,59 és 99,54 m/m\%-ok viszonylag jó egyezést mutatnak a hibrid rétegek névleges LDO-tartalmával (0, 20, 40, 60, 80 és $100 \mathrm{~m} / \mathrm{m} \%)$ (4. táblázat).

A filmek szintézise után meghatároztam a kialakított hibrid rétegek rétegvastagság és porozitás értékeit. Az LDO tartalom növelésével nőtt a rétegvastagság (mért vastagság értékek: 64-201 $\mu \mathrm{m}$ ) (4. táblázat). A müszeresen mért értékek mellett meghatároztam az összetétel alapján számított 
rétegvastagság értékeket is, a hibrid rétegek $\left(5,8 \pm 0,2 \mathrm{mg} / \mathrm{cm}^{2}\right)$ fajlagos felületi mennyiségéből és az összetevők előzőleg meghatározott sürüség értékeiből ( $\rho_{\text {LDO }} 0,52 \mathrm{~g} / \mathrm{cm}^{3} ; \rho_{\text {fluorpolimer: }} 1,10 \mathrm{~g} / \mathrm{cm}^{3}$ ). A számítások szerint a tiszta fluoropolimer rétegvastagsága 52,8 $\mu$ m-nek adódott, a hibrid rétegek rétegvastagsága pedig nőtt az LDO tartalommal. A mért és a számított értékek közötti különbség a film porozitására vonatkozik. Az eredmények azt mutatták, hogy a kiszámított porozitási értékek $17,5 \%$ (tiszta polimer réteg) és 58,1 \% (40 m/m\% LDO-t tartalmazó hibrid réteg) között változtak. A polimer mátrixba inkorporált LDO részecskék tehát növelték a kialakított kompozit rétegek porozitását, ezzel egy lazább, nyitottabb szerkezet alakult ki a kiindulási polimerhez képest.

A 49. ábrán láthattuk, hogy ezek a hibrid rétegek változatos felületi struktúrával rendelkeznek az LDO tartalom növelésével. Ezen rétegek felületi érdességét a 3.3.12. pontban bemutatott profilometriás méréssel jellemeztem. A p(PFDAk) fluoropolimer réteg érdessége $\left(R_{q}\right.$, négyzetes durvasága) 0,002 $\pm 0,0002 \mu \mathrm{m}$-nak adódott (51. (a) ábra) ezzel szemben az LDO tartalom növelésével a kezdeti sima felület egyre strukturáltabbá, érdesebbé vált. A legnagyobb érdességet a 80 m/m\% LDO tartalom esetén kaptam, az $R_{q}=15,30 \pm 2,04 \mu$ m-nek adódott. Megjegyzendő, hogy -az AFM mérések alapján- a kialakított felület nem csak mikro-, hanem nano-szinten is érdességet mutatott $\left(R_{q}=38,4 \mathrm{~nm}\right)$.

(a)

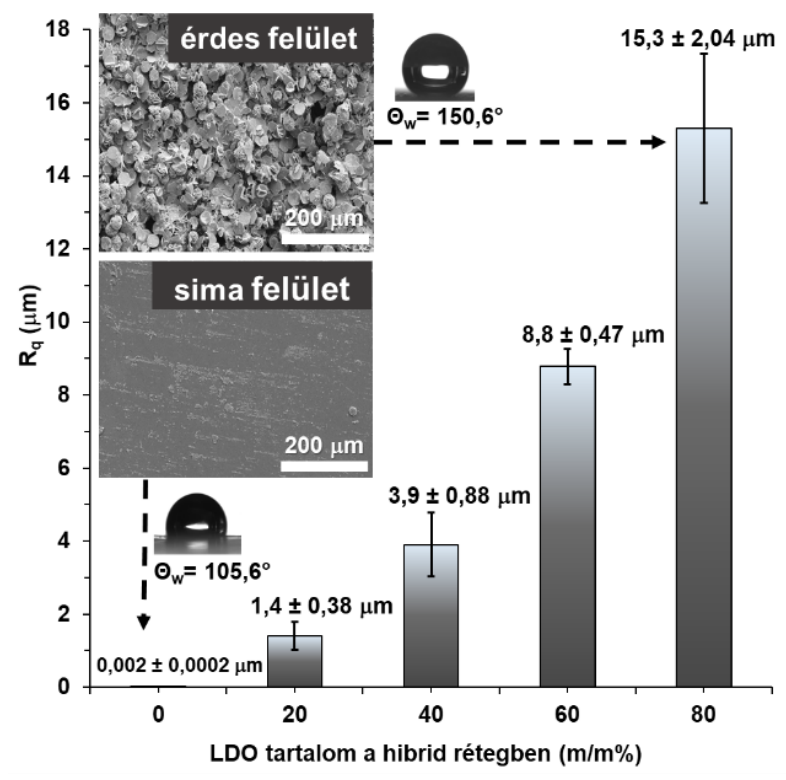

(b)

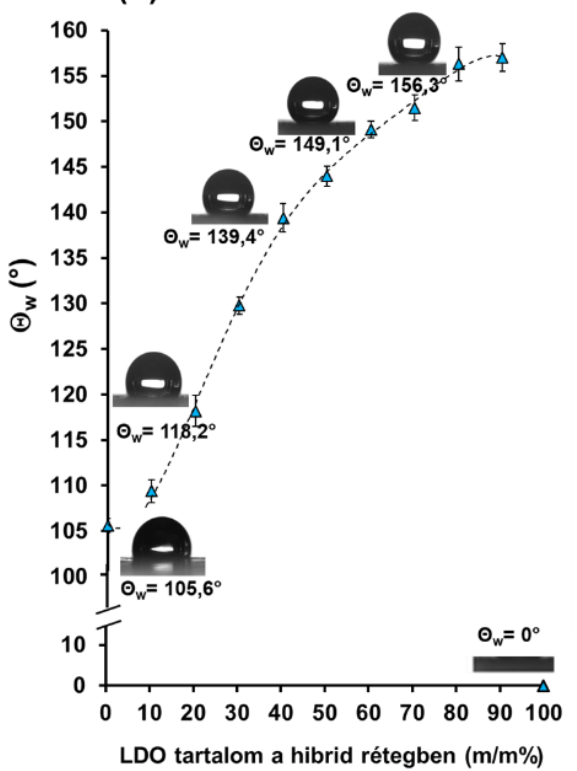

51. ábra. A felületi érdesség $\left(R_{q}\right)(\mathrm{a})$ és vízre kapott peremszög értékek $\left(\Theta_{\mathrm{w}}\right)(\mathrm{b})$ alakulása az egyre növekvő LDO tartalmú p(PFDAk) polimer rétegeken.

Az LDO/ fluoropolimer rétegek desztillált víz tesztfolyadékra mutatott nedvesedési tulajdonságát peremszög mérésekkel is meghatároztam a 3.3.13. fejezetben leírtak alapján.

Az 51. (b) ábrán az LDO tartalmú fluoropolimer alapú hibrid rétegek felületén kapott látszólagos peremszög $\Theta_{\mathrm{w}}$ értékeit mutatja az LDO-tartalom függvényében. A tiszta fluropolimer 
esetén ez az $\Theta_{\mathrm{w}}$ érték $105,6^{\circ} \pm 0,76^{\circ}$-nak adódik, mely alacsony energiájú sík felületre jellemző [132]. Az LDO tartalom növelésével az érdesség mellett a vízre kapott kontakt szögek $\left(\Theta_{\mathrm{w}}\right)$ is jelentősen nőttek, a 80 és $90 \mathrm{~m} / \mathrm{m} \%$ LDO-tartalom esetén a mért értékek $156,3^{\circ} \pm 1,88^{\circ}$ és $157,1^{\circ} \pm$ $1,53^{\circ}$ (51. (b) ábra).

Megjegyzendő azonban, hogy a tiszta LDO részecskéket (100 m/m\% LDO) tartalmazó réteg (fluoropolimer nélkül), tökéletes nedvesedést mutatott, vízre történő érintkezési szöge $\Theta_{\mathrm{w}}=0^{\circ}$-nak adódott. Ennek magyarázata az LDO részecskék hidrofil jellegéből ered, ami a filmképzés során porózus, hidrofil réteg kialakulását eredményezte, mely vízre tökéletes, szuperhidrofil tulajdonságot mutatott (51. (b) ábra).

Az előállított LDO/ fluorpolimer kompozit rétegek (0, 20, 40, 60 és 80 m/m\% LDO tartalom) vízre történő további nedvesedési tulajdonságát dinamikus peremszög mérésekkel is jellemeztem (lásd 3.3.13. fejezet), Drelich módszere alapján [97]. A mérés során a p(PFDAk) fluoropolimer réteg felületén vízre kapott haladó $\left(\Theta_{a d v}\right)$ peremszög értékek $\Theta_{6,1 \mu 1}=105,6^{\circ}$-tól $\Theta_{49,7 \mu 1}=89,1^{\circ}$-ig csökkent, a csepptérfogat növekedésével (52. ábra). Ezt követően, a csepp térfogatának csökkenésével, a hátráló $\left(\Theta_{\text {rec }}\right)$ peremszög értékek további csökkenést mutattak, egészen $24,7^{\circ}$-ig, ellentétben a kezdeti statikus peremszög értékhez képest $\left(\Theta_{\mathrm{w}}=105,6^{\circ} \pm 0,76^{\circ}\right)$.

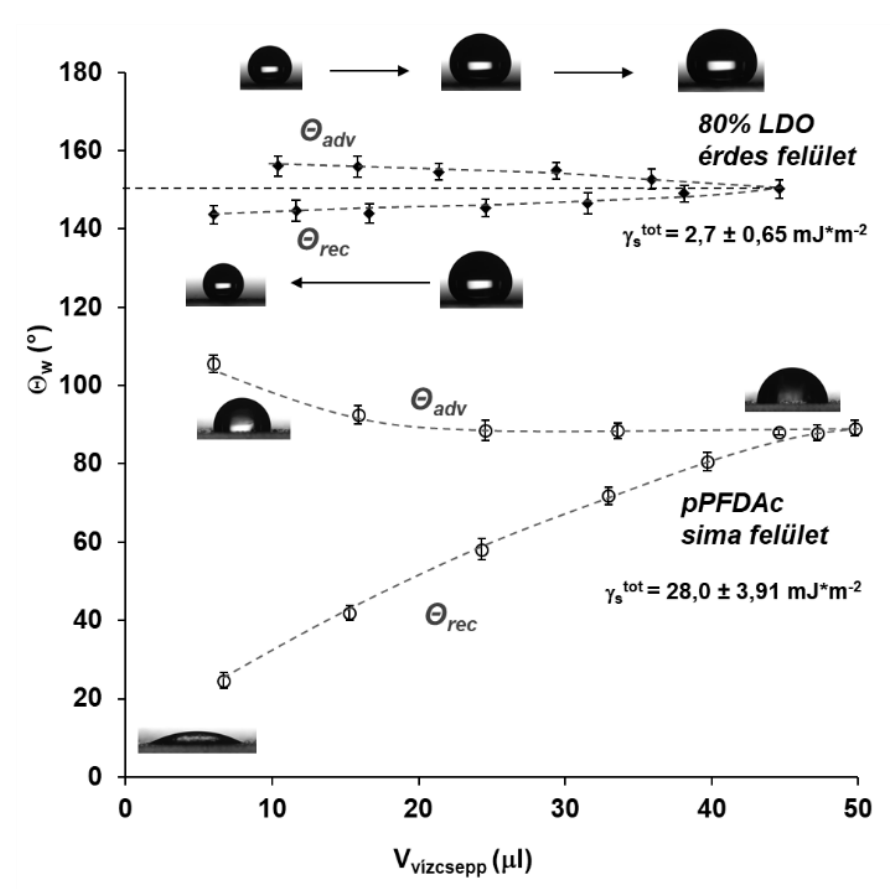

52. ábra. A desztillált víz tesztfolyadékra kapott haladó $\left(\Theta_{\mathrm{adv}}\right)$ és hátráló $\left(\Theta_{\mathrm{rec}}\right)$ peremszög értékek a sima felületü p(PFDAk) polimer és az érdes felületü, $80 \mathrm{~m} / \mathrm{m} \%$ LDO tartalmú, kompozit réteg esetén.

Ez a nagy peremszög hiszterézis $\left(\Delta \Theta=80,9^{\circ}\right)$ a sík felületű p(PFDAk) fluoropolimer réteg relatíve jól nedvesedő tulajdonságát jelzi. Azonban, a szuperhidrofób tulajdonságokat mutató 80 
m/m\% LDO-tartalmú hibrid réteg esetén a vízre kapott haladó $\left(\Theta_{a d v}\right)$ peremszög értékek kis mértékben változtak, $\Theta_{7,0 \mu 1}=156,3^{\circ}$-tól $\Theta_{44,6 \mu 1}=150,2^{\circ}$-ig csökkent, majd a hátráló $\left(\Theta_{\text {rec }}\right)$ peremszög értékek további kismértékü csökkenést mutattak (egészen 143,7-ig) (52. ábra).

Ez a kis peremszög hiszterézis $\left(\Delta \Theta=12,4^{\circ}\right)$ tipikusan a szuperhidrofób felületekre jellemző [133]. A kapott mérési eredményekből meghatároztam a kompozit rétegek látszólagos felületi szabad energia $\left(\gamma_{\mathrm{s}}{ }^{\text {tot}}\right)$ értékeit (15. egyenlet felhasználásával). A sima felületü fluoropolimer réteg esetén a $\gamma_{\mathrm{s}}{ }^{\text {tot }}=28,0 \pm 3,91 \mathrm{~mJ} / \mathrm{m}^{2}$-nak adódott, mely az irodalmomból jól ismert teflonszerü sík rétegek felületi szabad energia értékével jó egyezést mutatott [134].

A fluoropolimerre kapott felületi szabad energia értéket tovább lehetett csökkenteni, a sima felület megfelelő érdesítésével, egészen $2,7 \pm 0,65 \mathrm{~mJ} / \mathrm{m}^{2}$-ig, mely a szuperhidrofób $80 \mathrm{~m} / \mathrm{m} \% \mathrm{LDO} /$ fluoropolimer rétegre volt jellemző. A nedvesedési tulajdonságokból, azaz a haladó- és hátráló peremszög értékek alapján meghatározott látszólagos felületi energia értékek jól mutatják a kétféle felület közötti különbségeket. Az alacsony felületi szabad energiájú $\left(\gamma_{\mathrm{s}}{ }^{\text {tot }}=28,0 \pm 3,91 \mathrm{~mJ} / \mathrm{m}^{2}\right)$ $\mathrm{p}\left(\right.$ PFDAk) polimer sima felülete $\left(R_{q}=0,002 \pm 0,0002 \mu \mathrm{m}\right)$ tovább csökkent a felület érdességének növelésével $\left(R_{q}=15,3 \pm 2,04 \mu \mathrm{m}\right)$. Ezt a felületi érdesség által okozott felszíni szabad energia csökkentő tendenciáját az 53. ábra szemlélteti.

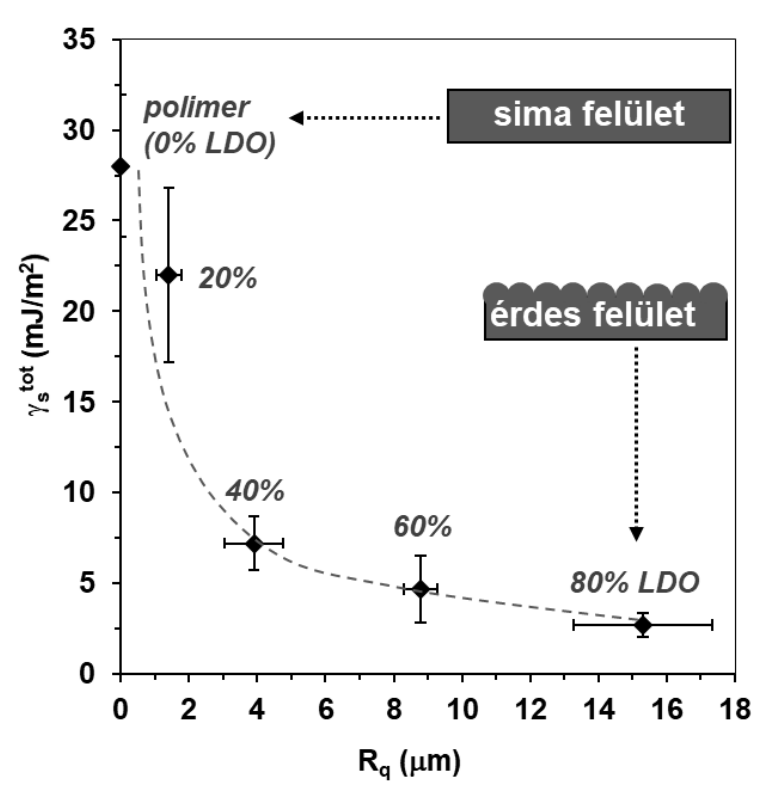

53. ábra. Az LDO/ $\mathrm{p}(\mathrm{PFDAk})$ kompozit rétegek látszólagos felületi energia értékeinek $\left(\gamma_{\mathrm{s}}{ }^{\text {tot }}\right)$ változása az érdesség $\left(R_{q}\right)$ függvényében.

Az eredmények azt mutatják, hogy amikor az LDO részecskék arányát 0 -ról $80 \mathrm{~m} / \mathrm{m} \%$-ra növeljük a hidrofób fluoropolimerben, az $R_{q}$-érték folyamatosan növekszik $(0,002 \pm 0,0002 \mu \mathrm{m}$-röl $15,3 \pm 2,04 \mu \mathrm{m}$-re), és a $\gamma_{\mathrm{s}}{ }^{\text {tot }}$-értékek exponenciálisan csökkentek $\gamma_{\mathrm{s}}{ }^{\text {tot }}=28,0 \pm 3,91 \mathrm{~mJ} / \mathrm{m}^{2}$-röl 2,7 $\pm 0,65 \mathrm{~mJ} / \mathrm{m}^{2}$-re. 
Az LDO részecskék $12 \mathrm{~m} / \mathrm{m} \%$-os ZnO-tartalmának köszönhetően a kialakított LDO/ fluoropolimer rétegek szuperhidrofób tulajdonságuk mellett fotoreaktív tulajdonságokra is szert tehetnek. A fotokatalitikus folyamat során olyan reaktív oxigén tartalmú gyökök (ROS) keletkeznek, mint például a szuperoxid $\left(\mathrm{O}_{2}^{-}\right)$, hidrogén-peroxid $\left(\mathrm{H}_{2} \mathrm{O}_{2}\right)$, vagy hidroxil-gyök ( $\left.\mathrm{HO}\right)$ [135], amelyek - nagy oxidációs potenciáljuk révén- a szerves szennyező anyagokat fotodegradálják [88], ill. baktériumok inaktiválásáért felelősek és irreverzibilis DNS-lebontást okoznak a baktériumsejtekben [89, 136, 137].

A rétegek fotoreaktív tulajdonságát igazolva, meghatároztam a rétegek felületén képződő szabadgyökök koncentrációját $\left(\mathrm{H}_{2} \mathrm{O}_{2}\right.$ egyenértékben kifejezett) luminometriás módszerrel a 3.3.15. pontban leírtak szerint. A LED típusú $\left(\lambda_{\max }=405 \mathrm{~nm}\right)$ fényforrással megvilágított hibrid rétegek felszínén képződő reaktív gyökök mennyiségét a hidrogén-peroxid és luminol kemilumineszcens reakcióból számítottam ki (3.3.15. fejezet). A szabadgyökök élettartama femto- vagy pikoszekundumban mérhető [138]. A képződött hidrogén-peroxid lebomlása azonban szobahőmérsékleten lassú és luminométerrel mérhető [139]. A mért $\mathrm{H}_{2} \mathrm{O}_{2}$ koncentráció arányos a megfelelő megvilágítás során keletkező különböző szabad gyökökkel. Az 54. ábrán az egyes hibrid rétegek esetén a $\mathrm{H}_{2} \mathrm{O}_{2}(\mathrm{mM})$ számított ekvivalens koncentrációs értékek láthatók a megvilágítási idő függvényében.

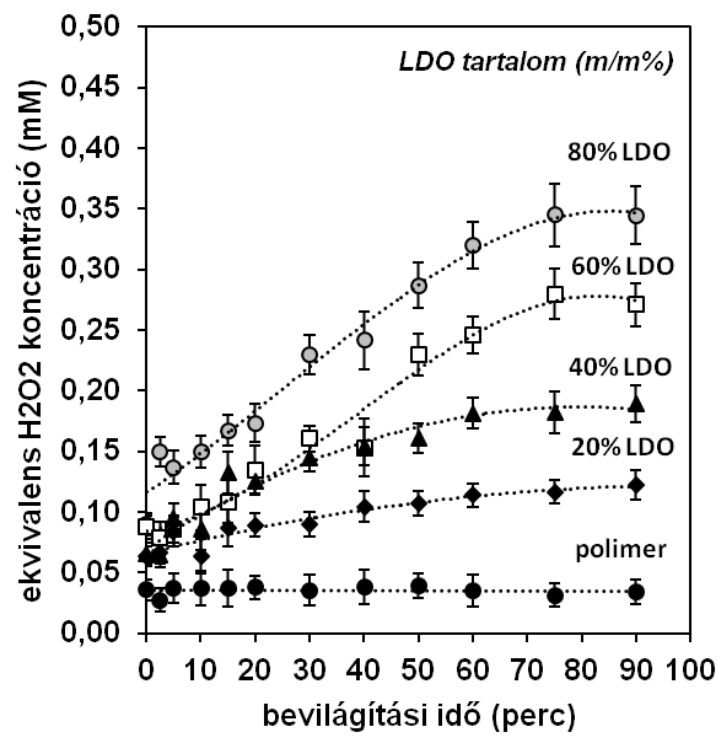

54. ábra. Az LDO/ p(PFDAk) polimer tartalmú kompozit rétegek felszínén képződő reaktív szabadgyökök koncentrációjának $(\mathrm{mM})$ változása a bevilágítási idő függvényében. Alkalmazott fényforrás: $\mathrm{S} 1\left(\lambda_{\max }=365 \mathrm{~nm}\right)$.

Az eredmények azt mutatták, hogy az egyre növekvő LDO tartalmú hibrid rétegek jelenlétében reaktív szabad gyökök keletkeznek, melyek oldatbeli koncentrációja és a vizsgált időintervallumban (0-90 perc) telítettségi görbéket eredményezett. Ez azzal magyarázható, hogy a megvilágítás során 
a szerves polimer mátrix is részleges fotooxidációt szenved [140], ezáltal egyre több felületi fotokatalizátor részecske válik hozzáférhetővé, így egyre több szabad gyök keletkezik, mígnem - a felső polimer mátrix teljes degradációja után- a koncentrációjuk telítésbe fordul. A 80 m/m\% LDO/ fluoropolimer réteg esetén a termelt ROS mennyisége nagyobb $\left(0,34 \mathrm{mM} \mathrm{H} \mathrm{H}_{2}\right.$ ekvivalens), mint a legalacsonyabb LDO tartalom hibrid rétegek jelenlétében $\left(0,27 ; 0,19\right.$ és $0,12 \mathrm{mM} \mathrm{H}_{2} \mathrm{O}_{2}$ egyenérték 60, 40 és 20 m/m\% LDO tartalmú kompozit) a 90 percig tartó LED típusú fényforrás megvilágítása alatt.

Az LDO tartalmú hibrid rétegek fotoreaktív tulajdonságát tovább vizsgálva, az 55. ábrán a benzoesav modellmolekula koncentrációjának relatív változását láthatjuk az LDO/ polimer rétegeken, a megvilágítási idő függvényében. Az eredmények jól szemléltetik, hogy a tisztán LDO részecskékből kialakított réteg mutatta a legnagyobb fotoreaktív tulajdonságot, 240 perc UV-A fény $\left(\lambda_{\max }=365 \mathrm{~nm}\right)$ megvilágítási idő elteltével a kiindulási $(0,17 \mathrm{~g} / \mathrm{L})$ benzoesav modellmolekula 24 $\%$-át fotodegradálta $\left(25,0 \pm 0,5^{\circ} \mathrm{C}\right)$.

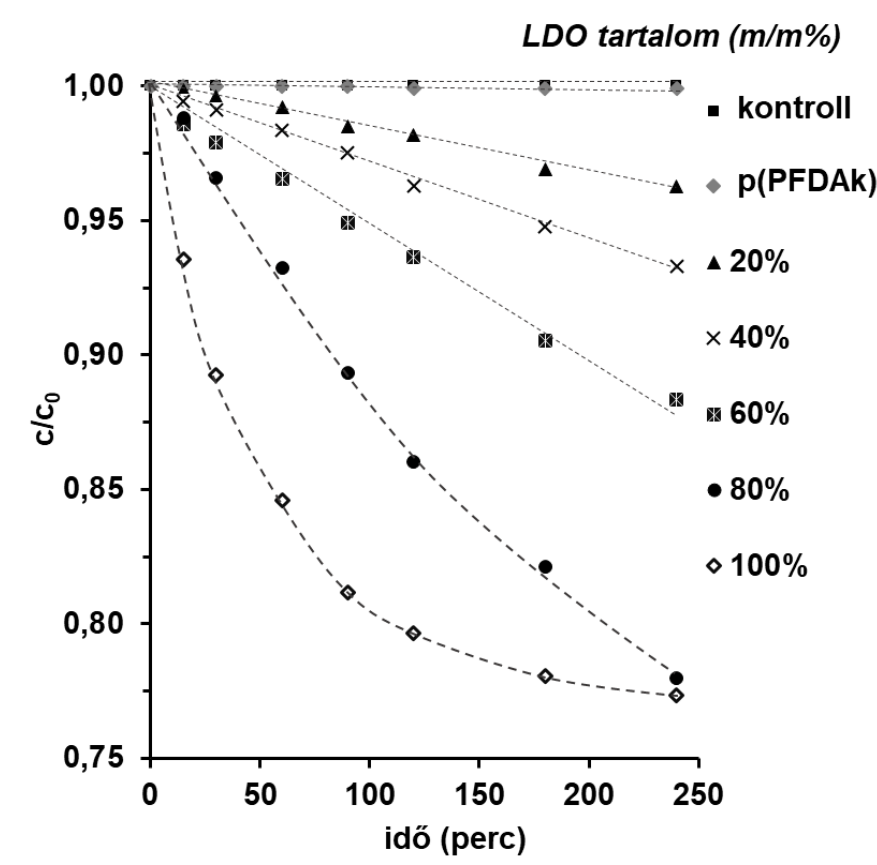

55. ábra. A benzoesav modellmolekula koncentrációjának relatív csökkenése az LDO/ flouropolimer rétegeken, a bevilágítási idő függvényében. Alkalmazott fényforrás: S1 $\left(\lambda_{\max }=365\right.$ nm) (szórás: $<5 \%$ ).

Az LDO részecskék immobilizálása a kis felületi energiával rendelkező fluoropolimer mátrixba, a fotokatalitikus reakciósebesség folyamatos csökkenését eredményezte, a tiszta LDO filmhez képest, mivel a polimer részben bevonta az LDO fotokatalizátor részecskéket (56. ábra, beszúrt SEM felvétel). Ahogy az 55. ábrán látható, fotodegradáció nem volt megfigyelhető a tiszta polimer film és kontroll mérés (üres reaktor) esetében, ezért a direkt fotolízis kizárható. A 80 m/m\% LDO 
tartalmú hibrid film hasonló eredményt mutatott, mint a tiszta LDO film, 240 perc megvilágítási idő elteltével a kiindulási $(0,17 \mathrm{~g} / \mathrm{L})$ benzoesav modellmolekula $24 \%$-át fotodegradálta.

A benzoesav fotodegradációja során a bontási görbékből meghatározott reakciósebességi állandókat $\left(\mathrm{k}^{\prime}, \min ^{-1}\right)$ az 56. (a) ábrán foglaltam össze az LDO-tartalom függvényében.

(a)

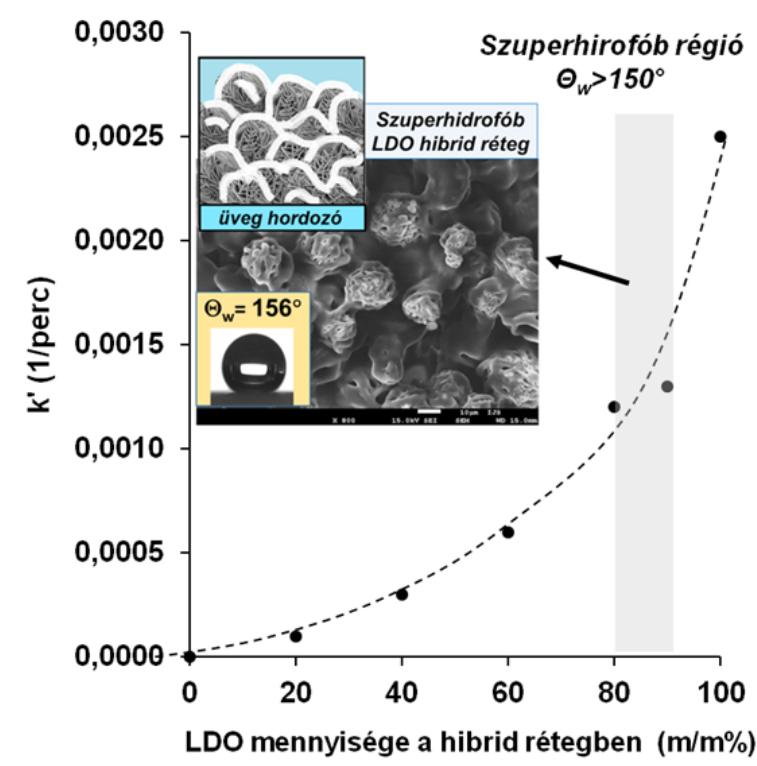

(b)

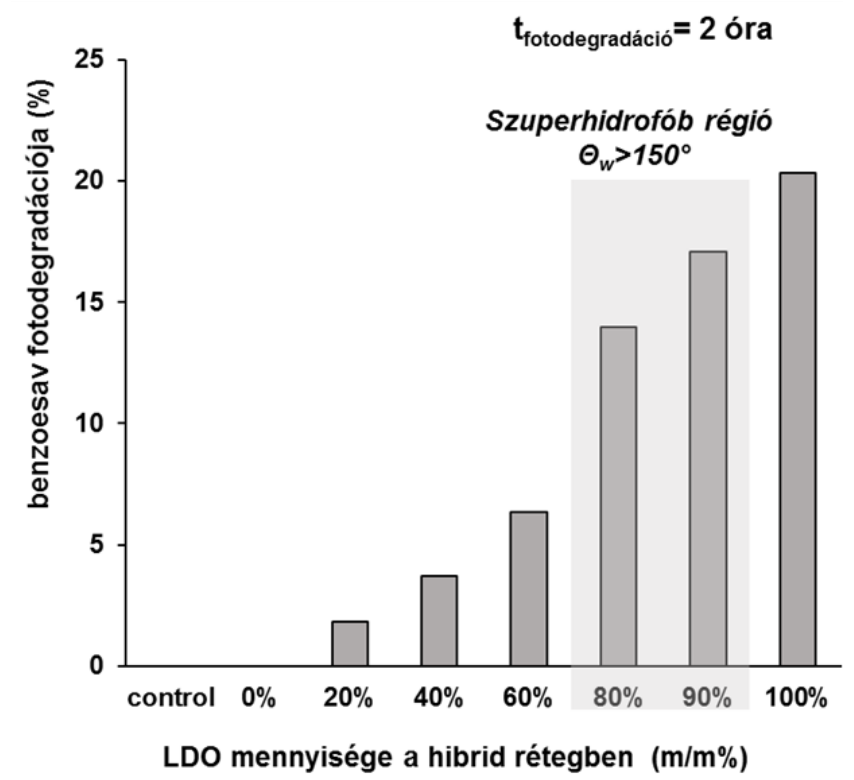

56. ábra. A benzoesav modellmolekula bontása során meghatározott sebességi együttható (k’) (a) és az elbontott benzoesav mennyisége (\%) (b) az egyre növekvő LDO tartalmú polimer rétegeken 2 óra bevilágítási idő elteltével (szórás: $<5 \%$ ).

A k'-értékeket a rögzített koncentráció-idő adatpárok alapján, a $\ln \left(\mathrm{c} / \mathrm{c}_{0}\right)=-\mathrm{k}$ ’t egyenlet segítségével határoztam meg, ahol c a benzoesav koncentrációja adott időpillanatban (t), ill. $\mathrm{c}_{0}$ a tesztmolekula kezdeti koncentrációja $\left(\mathrm{c}_{0}=0,17 \mathrm{~g} / \mathrm{L}\right)$. Az eredményeket tekintve az LDO-tartalom növelése exponenciálisan növeli a k'-értékét: az igazán számottevő növekedés $60 \mathrm{~m} / \mathrm{m} \%$-os LDOtartalom felett figyelhető meg, 80, 90 és 100 m/m\%-os LDO-tartalom mellett a sebességi állandók rendre 0,0012, 0,0013, illetve 0,0025 $\mathrm{min}^{-1}$-nek adódtak. A kizárólag LDO-ból álló, szuperhidrofil felület $\left(\Theta_{w}=0^{\circ}\right) 2$ órás UV-A- megvilágítása során a benzoesav molekulák kezdeti mennyiségének 20,7 \%-át, a szuperhidrofób $\left(\Theta_{w}>150^{\circ}\right), 80 \mathrm{~m} / \mathrm{m} \%$ LDO-t tartalmazó felület besugárzása során pedig 14,4 \%-át sikerült elbontani (56. (b) ábra).

Összefoglalva a kapott eredményeket elmondható, hogy 80-90 m/m\% LDO tartalmú hibrid rétegek szuperhidrofób $\left(\Theta_{w}>150^{\circ}\right)$ és fotokatalitikus tulajdonsággal is rendelkeznek (57. ábra). Ez a kettős öntisztító tulajdonságú hibrid réteg kialakítása nagyon hasznos lehet különböző alkalmazásokban, ott ahol például a víz által okozott nedvesedés komoly problémákat okoz (pl. korrózió, jegesedés), vagy éppen a szerves szennyező anyagok, mikroorganizmusok jelenléte a 
felületen jelent megoldandó feladatot (pl. egészségügyi termek, mütőszobák, élelmiszeripar, otthonok, stb.).

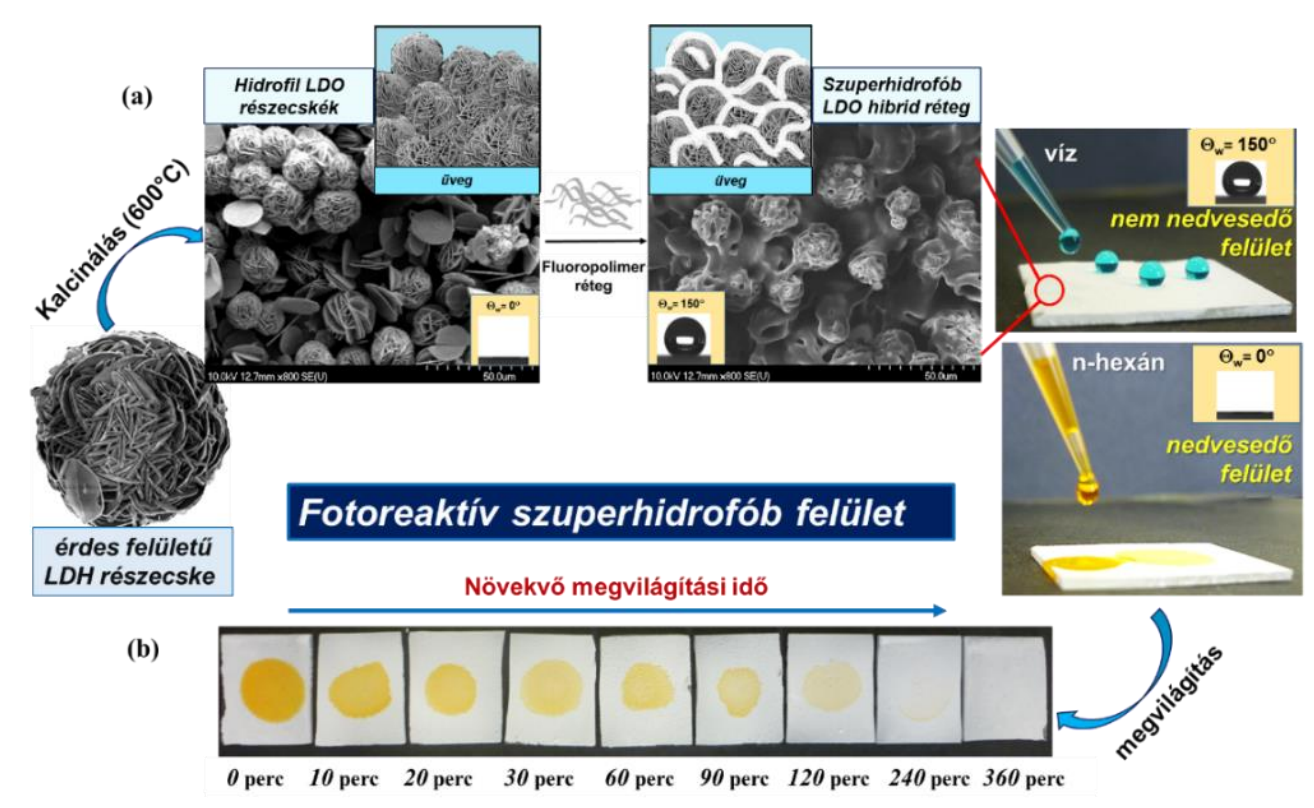

57. ábra. A szuperhidrofób és fotoreaktív tulajdonságokkal rendelkező réteges kettős oxid (LDO)/ fluoropolimer hibrid réteg sematikus ábrája és SEM-felvételei (a).

A kék színü vízcseppek nem nedvesítik a kialakított filmet, míg az apoláros, sárga színü (szudán I) n-hexános festékoldat szétterül a rétegen, de ezt követően fotodegradációt szenved (b).

\subsubsection{Baktériumok adhéziójának vizsgálata kompozit rétegek felszínén}

A különböző anyagi minőséggel rendelkező felületkhez történő bakteriális tapadás (adhézió) bonyolult folyamat, amelyet a baktériumsejtek és az anyagfelületek különböző fizikai-kémiai tulajdonságai befolyásolnak [141]. A szakirodalmi adatok szerint a kémiai összetétel [142], a felületi érdesség $[143,144]$ a felületi szabad energia és a felületi nedvesedési tulajdonságok összefüggnek és gyakran befolyásolják a baktérium sejtek adhézióját [145, 146]. Az előzőekben bemutatott és jellemzett kis felületi energiával és érdességgel rendelkező LDO/ fluoropolimer rétegeken megvizsgáltam három baktériumtörzs (Staphylococcus aureus (S. aureus) ATCC 25923, Escherichia coli (E. coli) ATCC 35218 és Pseudomonas aeruginosa (P. aeruginosa) ATCC 27853)) adhézióját, a 3.3.16. fejezetben leírtak szerint. A baktériumsejtek megtapadását, a mikrobiológiában is használatos, kristályibolya festési módszerrel határoztam meg [147]. Ez a módszer azon alapul, hogy a kristályibolya festékmolekulák mind a Gram-pozitív, mind a Gram-negatív sejtek falán és membránján keresztül átjutva kölcsönhatásba lépnek a baktériumsejtek komponenseivel, lila színüre festve ezáltal a sejteket. Ezt követően az alkohollal történő ún. differenciálás során az oldószer a sejtekből kivonja a festéket és spektrofotometriásan detektálható kristályibolya festék 
optikai denzitás (620 nm hullámhossznál, OD $_{620}$ ) értéke közvetlenül arányos a felületen megtapadt baktériumok számával [101, 148, 149].

$\mathrm{Az}$ 58. ábra a hibrid rétegek felületén lévő három baktériumtörzs ( $S$. aureus, E. coli és $P$. aeruginosa) adhéziós képességét mutatja be a növekvő LDO-részecske-tartalom függvényében. A felszínre tapadt megfestett baktériumsejtekből felszabaduló kristályibolya festékre mért OD 620 egyértelmüen azt mutatja, hogy a baktériumok megtapadása (adhéziója) nagymértékben függ a felületi jellemzőktől, vagyis a kis energiájú felület hidrofil LDO részecskékkel történő érdesítése növelte a felületen megtapadt baktérium sejtek számát.

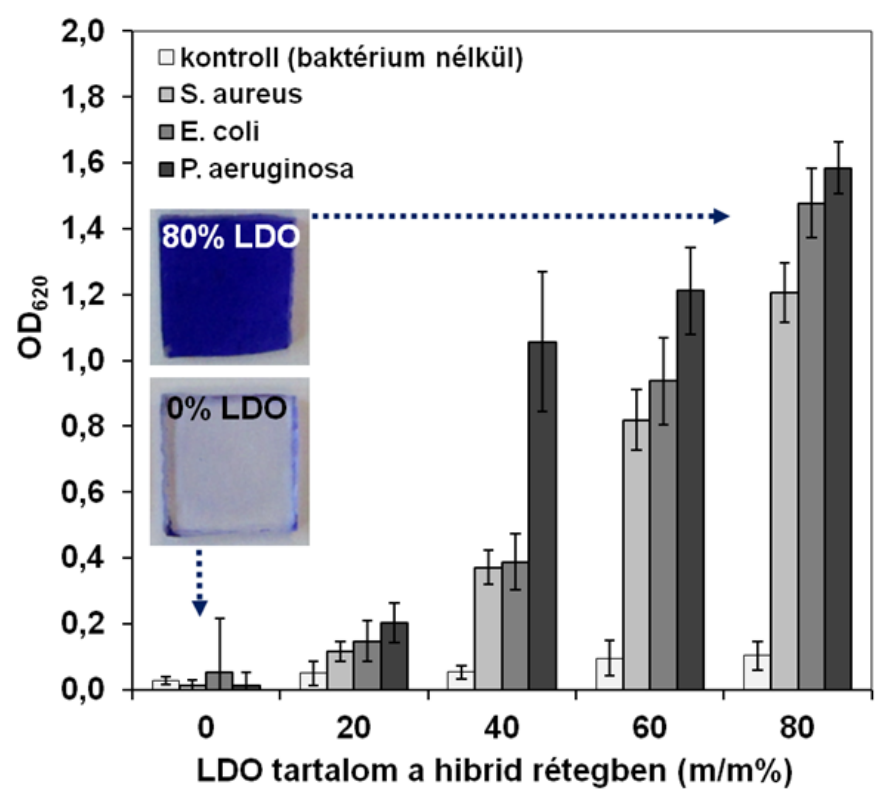

58. ábra. A kompozit rétegek felületén adszorbeálódott $S$. aureus, E. coli és $P$. aeruginosa baktériumok által felvett kristályibolya festék optikai denzitás (620 nm hullámhossznál, $\left.\mathrm{OD}_{620}\right)$ értékeinek alakulása az LDO tartalom $(\mathrm{m} / \mathrm{m} \%)$ függvényében.

Az 58. ábrán beszúrt fotók a kristályibolya festékkel megfestett rétegeket mutatják és jól szemléltetik, hogy a baktérium sejtek megtapadása a tiszta $(100 \mathrm{~m} / \mathrm{m} \%)$ fluoropolimer réteg viszonylag sima felületén a legkisebb mértékü. A vizsgált felület színtelen volt, ami azt jelenti, hogy a baktériumsejtek (mindhárom törzs esetén) nem vagy csak kis mértékben tapadtak a felülethez, 18 órás $37^{\circ} \mathrm{C}$-on, aerob körülmények között végzett inkubálás után; a kioldott festékoldatokra kapott $\mathrm{OD}_{620}$ értéke mindössze 0,01 és 0,05 között változott. A hibrid rétegek esetében a növekvő LDO töltőanyag tartalommal elöidézett növekvő felületi érdesség megjelenésével mindhárom baktériumtörzs felületi adhéziója fokozódott (58. ábra). Ez a legnagyobb mértékben a 80 m/m\%os LDO-tartalmú kompozit réteg $\left(R_{q}=15,3 \pm 2,04 \mu \mathrm{m}\right)$ esetében volt tapasztalható; a mért kristályibolya $\mathrm{OD}_{620}$ értéke 1,11-1,54 között volt detektálható. Az ábrán beszúrt fotón is jól látszik, 
hogy a felület $80 \mathrm{~m} / \mathrm{m} \%$ LDO-tartalomnál ibolyaszínü volt, ami a baktériumsejtek jelenlétét mutatja a felszínen (az 58. ábrán feltüntetett kép).

Az eredmények alapján azt tapasztaltuk, hogy a $P$. aeruginosa $\mathrm{OD}_{620}$ értke az $E$. coli- és $S$. aureus-hoz képest szignifikánsan nagyobb adhéziót mutat az egyre érdesebb felületen (58. ábra). Ezt a jelenséget a korábbi munkákban is megfigyelték [148, 149], melynek egyik lehetséges magyarázata, hogy a Pseudomonas törzsek nagy mennyiségü extracelluláris polimer anyagot (EPS) [146] termelnek, amelyek felelősek a biofilmek felülethez történő megtapadásáért [150]. Továbbá megjegyzendő, hogy a kontroll mérések (baktérium sejtek nélkül) azt mutatták, hogy a kristályibolya festék csak kis mértékben színezte meg a hibrid réteg felületet, azaz a technika alkalmas volt a vizsgált hibrid rétegek felületén megtapadt baktérium sejtek festésére.

A fentiekben bemutatott baktérium sejtek kompozit felülethez történő megtapadását SEM mérésekkel is vizsgáltam. Az 59. (a) ábrán a 80 m/m\% LDO-t tartalmazó hibrid réteg felületéröl készült SEM felvétel látható, mely jól szemlélteti az LDO lamellák részleges polimer borítottságát. A kis felületi energiájú fluoropolimer nem fedte le teljesen az LDO-részecskék felületét és így az LDO lamellákon izolált, polimer-szigetek alakultak ki (59. (a) ábra). Ez szerkezet heterogenitást eredményezett a kompozit felületen és az 59. (b) ábrán látható, hogy az S. aureus baktériumok az alacsony energiájú polimer felületek helyett elönyben részesítették a nagy energiájú LDO felületeket. Ez magyarázza a korábban bemutatott bakteriális adhézió kapacitás eredményét, mely a növekvő LDO-tartalommal megnövekedett, mivel a baktériumok a hidrofil LDO-lamellák felületén tapadtak meg és elkerülték a hidrofób fluoropolimerrel történő érintkezést.
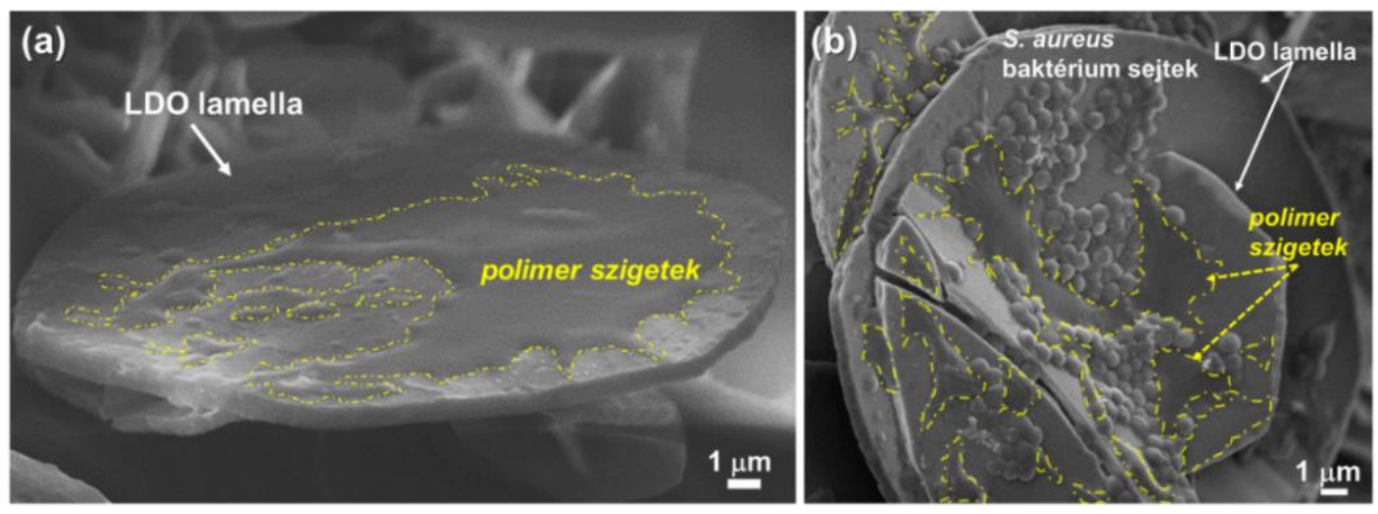

59. ábra. A polimer szigetekkel részlegesen borított LDO lamelláról készített reprezentatív SEM felvétel (a). Az S. aureus baktérium sejtek kolonizációja a hidrofil tulajdonságú LDO lamellán (b).

A további elektronmikroszkópos SEM felvételeket készítve, az 60. ábrán láthatjuk, hogy mind a három baktérium törzs esetén, a $P$. aeruginosa (a/1 és $\mathbf{a} / \mathbf{2}), E$. coli $(\mathbf{b} / \mathbf{1}$ és $\mathbf{b} / \mathbf{2})$ és $S$. aureus $(\mathbf{c} / \mathbf{1}$ és c/2) baktériumok a 18 órás bakteriális inkubálási idő elteltével az LDO/ fluoropolimer réteg felszínén tapadtak meg. Látható, hogy a baktériumsejtek többsége az LDO részecskék felületéhez 
tapad (60. ábra a/1, b/1 és c/1), pontosabban az LDO részecskék lamelláin és sarkaiban helyezkedtek el (60. ábra a/2, b/2 és c/2).
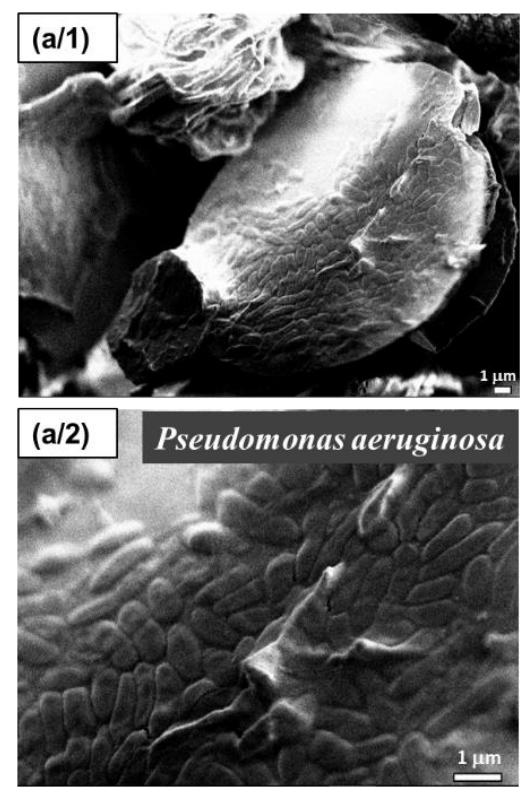
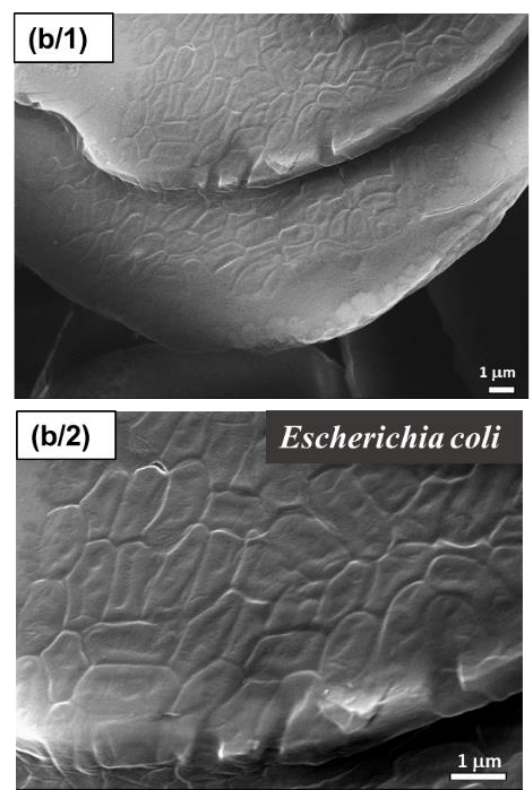
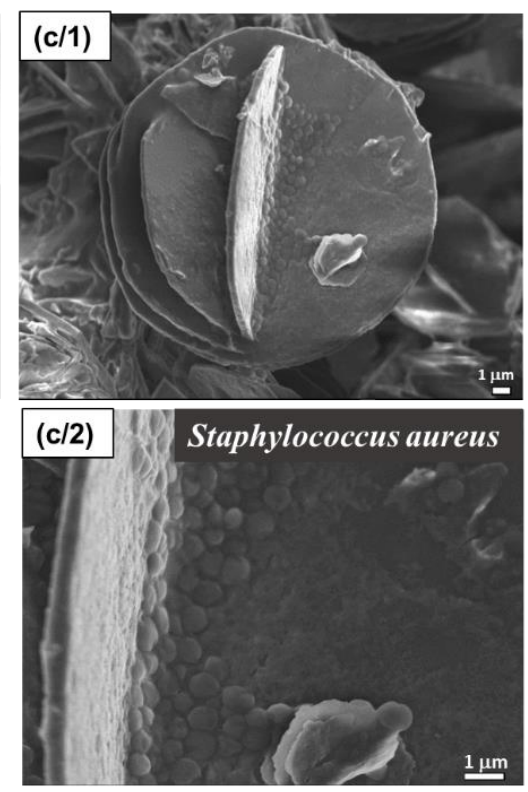

60. ábra. A $80 \mathrm{~m} / \mathrm{m} \%$ LDO tartalmú kompozit rétegen megtapadt $P$. aeruginosa (a/1 és a/2), $E$. coli (b/1 és b/2) és $S$. aureus (c/1 és c/2) baktérium sejtekről készült egy-egy reperezentatív SEM felvétel.

A 4.3.2. fejezetben bemutattam, hogy az LDO részecskék $\sim 12 \mathrm{~m} / \mathrm{m} \%$-os ZnO tartalmának köszönhetően az előállított hibrid rétegek fotokatalitikus tulajdonságra tehetnek szert, azaz megfelelő fényforrás alkalmazása mellett, reaktív gyökök keletkeznek, amelyek felelősek mikroorganizmusok inaktiválásáért. Ennek reprezentálására munkám folytatásaként megvizsgáltam a $80 \mathrm{~m} / \mathrm{m} \%$ LDO tartalmú hibrid rétegek felszínén megtapadt baktérium sejtek bevilágítás hatására történő inaktiválását is. Fluoreszcens mikroszkópos mérésekkel tanulmányoztam az élő és inaktivált (sérült) $P$. aeruginosa baktérium sejtek számát a 3.3.17. fejezetben leírtak alapján. A 61. ábrán az élő (zöld) és sérült (piros) $P$. aeruginosa sejtek fluoreszcens mikroszkópiás képei láthatók, a 80 $\mathrm{m} / \mathrm{m} \%$ LDO-tartalmú hibrid rétegen 0,60 és 120 perc megvilágítási idő elteltével.

A kiindulási időpontban (0 perc) az élő baktériumok sejtjeinek zöld emissziója látható (Syto 9), és 120 percnyi megvilágítás után a zöld emisszió intenzitása jelentősen csökken (61. ábra). Ezzel párhuzamosan, ugyanazon kezdeti időpontban elhanyagolható (1-2) sérült (inaktivált) baktérium sejteket figyelhetünk meg $\mathrm{t}=0$ percnél, azonban 120 perc megvilágítás után a sérült (vörös emissziót mutató) sejtek száma nő (61. ábra). 

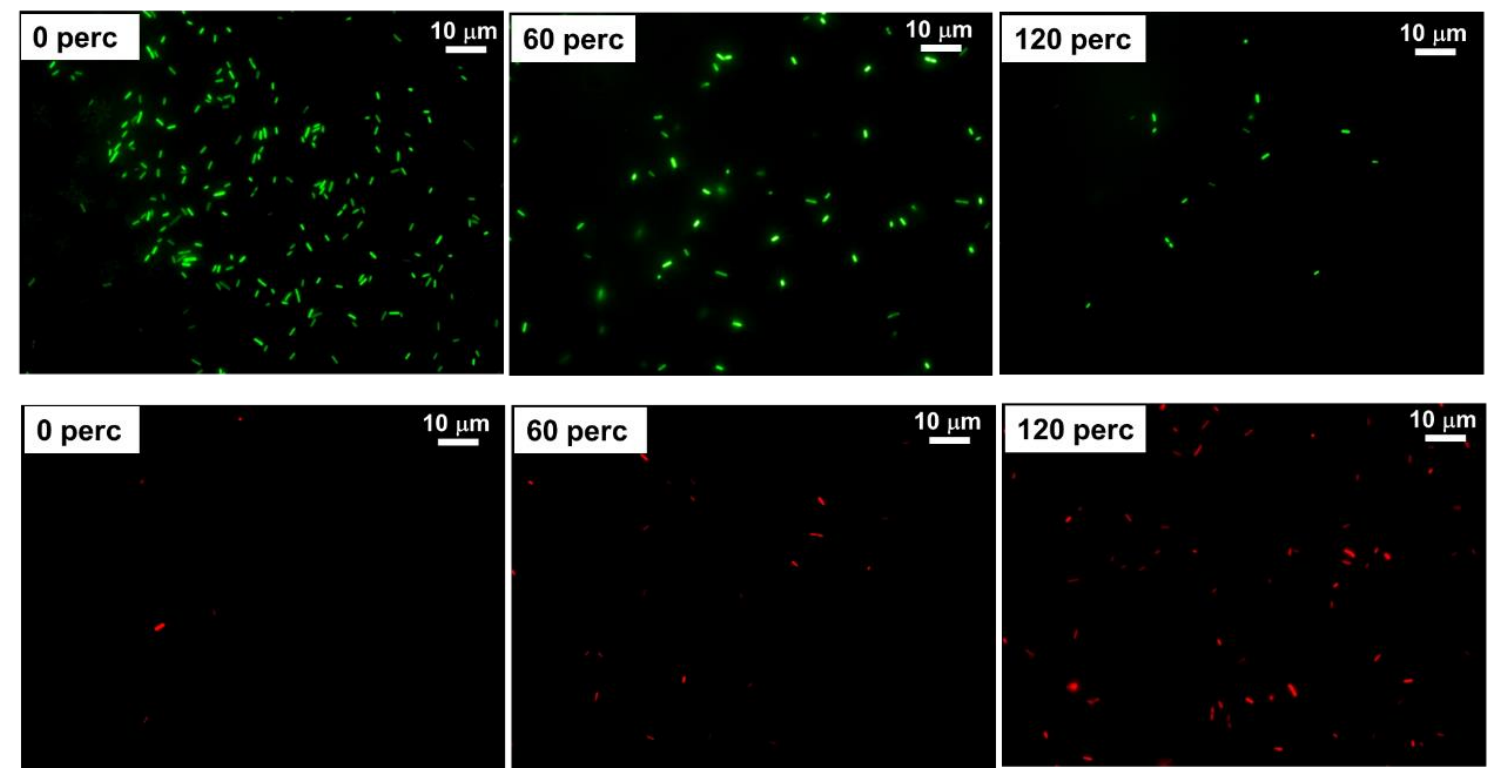

61. ábra. Az élő (zöld) és inaktivált (piros) Pseudomonas aeruginosa baktérium sejtekről fluoreszcens mikroszkóppal készült felvételek, a $80 \mathrm{~m} / \mathrm{m} \%$ LDO tartalmú kompozit rétegen 0,1 és 2 óra bevilágítási idő elteltével.

A fluoreszcens mikroszkópos mérések alapján összefoglalásként elmondható, hogy a hibrid réteg felszínéről nyert élő $P$. aeruginosa baktérium sejtek száma $93 \%$-kal csökkent 120 perc megvilágítási idő elteltével és ezzel párhuzamosan a sérült baktérium sejtek száma $46 \%$-kal nőtt (62. ábra).

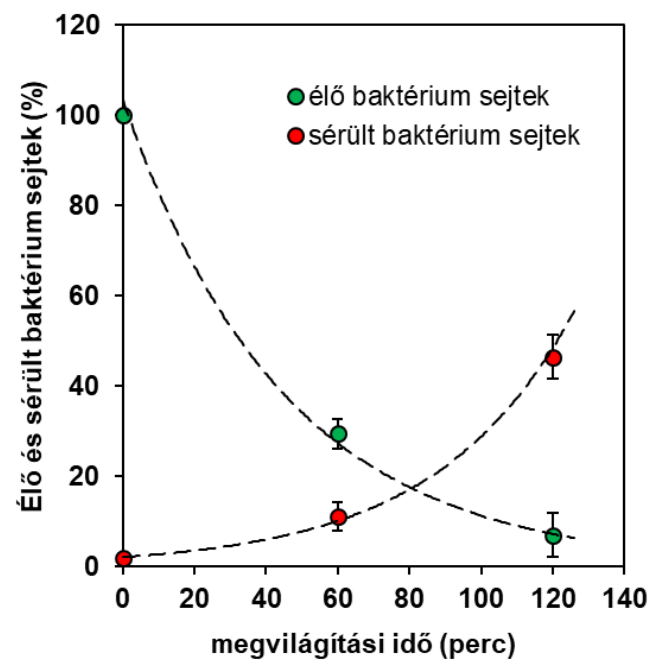

62. ábra. A fluoreszcens mikroszkóppal készült felvételek alapján számolt élő és inaktivált Pseudomonas aeruginosa baktérium sejtek \%-os megoszlása a megvilágítás idő függvényében. 


\subsection{HAp/ $\mathrm{TiO}_{2} /$ p(EA-co-MMA kompozitok jellemzése}

A szervetlen töltőanyagot tartalmazó polimer alapú hibrid rétegek kialakítása során alkalmazott polimer kötőanyagok tulajdonságai erősen befolyásolják a kapott fotokatalizátor/polimer hibrid anyagok fotokatalitikus és antibakteriális tulajdonságait. Veres Ágnes Ph.D. értekezésében bemutatta, hogy a rögzítő polimer hidrofilitása is jelentősen befolyásolja a fotooxidációt: lényegesen magasabb fotodegradációs sebességet kapott a hidrofil polimer alapú hibrid rétegre, mint a hidrofób polimer alapú hibrid réteg esetén [151].

Munkám során további célként tüztem ki egy hatékonyabb fotokatalitikus kompozit réteg kialakítását. Olyan $\mathrm{TiO}_{2}$ fotokatalizátor tartalmú és p(EA-co-MMA) rögzítőpolimer alapú kompozit filmeket állítottam elő, melyekben az előbbi két komponens mellett lamellás szerkezetü HAp töltőanyagot alkalmaztam, hogy lazább szerkezetü kompozit filmet kapjak.

\subsubsection{Hidroxiapatit (HAp) lamellák szerkezeti jellemzői}

A hidroxiapatit (HAp) lamellákat csapadékképzéses eljárással állítottam elő a 3.2.5 fejezetben bemutatott lépések és reakciókörülmények alkalmazása mellett.

A keletkezett HAp minta szerkezetét röntgendiffrakciós méréssel jellemeztem, a 63. (a) ábrán a por minta diffraktogramja látható. Az elsődleges reflexió $2 \Theta=26,0^{\circ}$ szögnél figyelhető meg, mely megfelel a HAp H (002) Bragg reflexiójának. Lúgos körülmények között (pH=11-12) az instabil kalcium-foszfát $(\mathrm{CaP})$, vagy amorf kalcium-foszfát (ACP) képződése a kristályos HAp fázisok megjelenésével párhuzamosan jelentkezik [152]. További jellemző reflexiókat figyeltünk meg $2 \Theta=$ $32,1^{\circ}$-os szögnél, mely az ACP-ra és a HAp H-ra (211) jellemző, valamint $2 \Theta=34,2^{\circ}$-nál, mely a trikalcium-foszfáthoz ( $\beta$-TCP) tartozik, mely szintén biokompatibilis anyag [93].
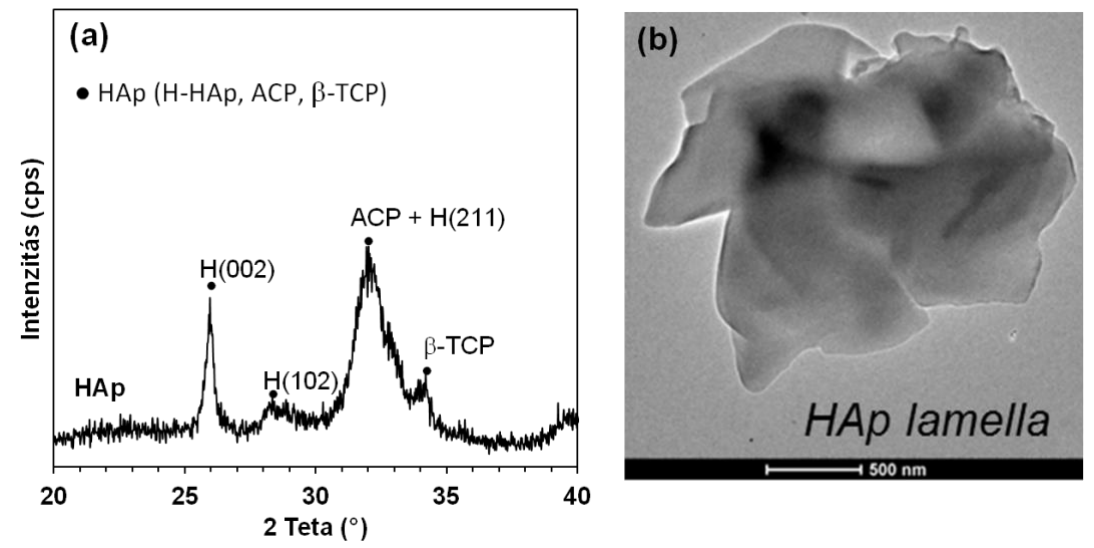

63. ábra. Az előállított HAp porminta diffraktogramja (a) és a kiindulási HAp mintáról készült reprezentatív TEM felvétel (b). 
A szintézis során kapott HAp minta lamellás morfológiával rendelkezik, ahogy az a 63. (b) ábrán is megfigyelhető, a mintáról készített TEM felvétel is igazolja. A $\mathrm{N}_{2}$-adszorpciós mérés alapján, pedig a minta fajlagos felülete $\left(a_{B E T}^{S}\right) 116 \mathrm{~m}^{2} / \mathrm{g}$-nak adódott.

\subsection{2 $\mathrm{TiO}_{2}$ / HAp kompozitok szerkezeti tulajdonságai}

A 3.2.10. fejezetben bemutatott $\mathrm{TiO}_{2} / \mathrm{HAp}$ kompozitokat szintén csapadékképzéses eljárással szintetizáltam, ill. összehasonlítás céljából $\mathrm{TiO}_{2} / \mathrm{HAp}$ fizikai keverék mintasorozatot is készítettem. A 64. (a) ábrán a kiindulási $\mathrm{HAp}, \mathrm{TiO}_{2}(\mathrm{P} 25)$ és egy kiemelt $(40 / 60 \mathrm{~m} / \mathrm{m} \%)$ összetételü $\mathrm{TiO}_{2} / \mathrm{HAp}$ porminták (csapadékképzéssel, ill. fizikai keverék $\mathrm{TiO}_{2} / \mathrm{HAp}$ ) röntgendiffraktogramjai láthatók.

A P25 $\mathrm{TiO}_{2}$ diffraktogramján megjelenő reflexiók a rutil (R) és az anatáz (A) fázisokhoz tartoznak [153]. Az XRD mérés során a számított anatáz : rutil aránya 78,2 : 21,8-nak adódott, mely jó egyezést mutatott az irodalmi adatokkal, ahol az anatáz : rutil aránya jellemzően (80-75\%) : (20$25 \%$ ) között változik [154]. A $2 \Theta=25,3^{\circ} ; 27,4^{\circ} ; 36,1^{\circ} ; 37,0^{\circ} ; 37,8^{\circ}$ és $38,5^{\circ}$ szögeknél megfigyelt reflexiók megfelelnek az $\mathrm{A}(101), \mathrm{R}(110), \mathrm{R}(101), \mathrm{A}(103), \mathrm{A}(004)$ és $\mathrm{A}(112)$ a $\mathrm{TiO}_{2} \mathrm{P} 25$ reflexióknak (64. (a) ábra).

(a)

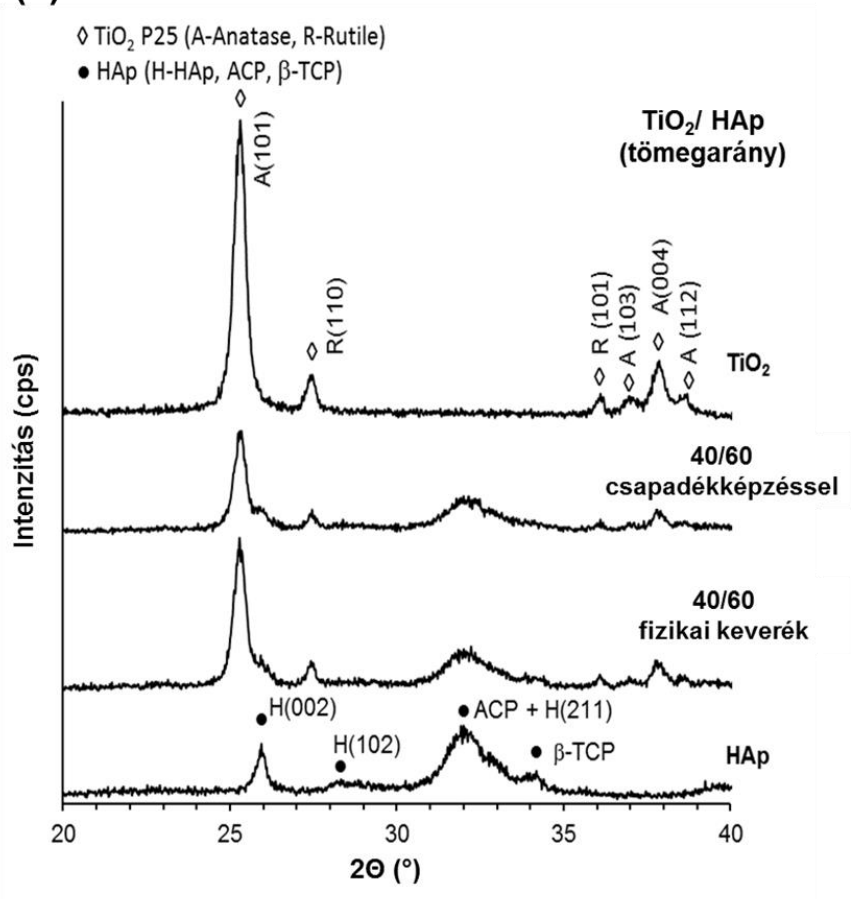

(b)

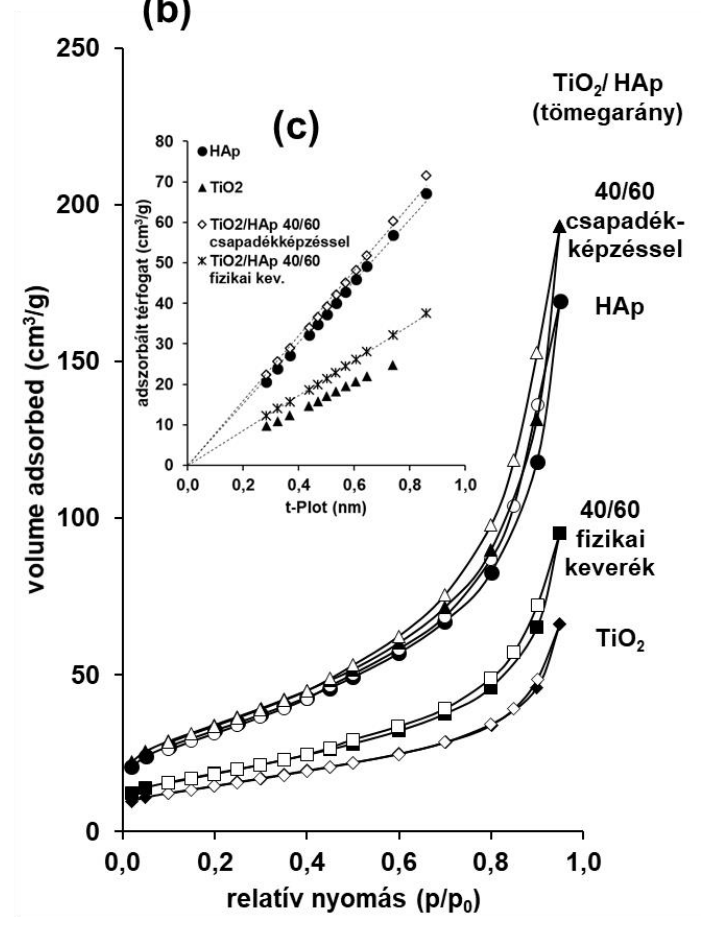

64. ábra. A kiindulási $\mathrm{HAp}$ és $\mathrm{TiO}_{2}(\mathrm{P} 25)$, valamint a fizikai keverék és csapadékképzéssel elöállított $40 / 60 \mathrm{~m} / \mathrm{m} \%$ összetételü $\mathrm{TiO}_{2} / \mathrm{HAp}$ porminták röntgendiffraktogramjai (a), nitrogén adszorpciós izotermái (b) és t-Plot ábrázolása (c). 
A kiindulási HAp minta esetében a $2 \Theta=26,0^{\circ} ; 28,5^{\circ} ; 32,1^{\circ}$ és $34,2^{\circ}$ szögeknél kapott reflexiók pedig megfelelnek a H(002); H(102); ACP és a HAp H (211), és végül a $\beta$-TCP-hoz tartozó Braggreflexiónak. Összehasonlítva a két sorozat diffraktogramjait (az együtt lecsapással előállított, ill. a kiindulási anyagok fizikai keverékekből előállított minták), új reflexiók megjelenése nem figyelhető meg.

A kompozit minták fajlagos felületének meghatározása során II. típusú adszorpciós izotermákat kaptam (64. (b) ábra), az adszorpciós és deszorpciós ágak közötti jelentős hiszterézis-hurkok azonban nem jelentkeztek. Az izotermák t-Plot ábrázolása (64. (c) ábra) azt mutatja, hogy a minták szerkezete nem porózus. A $\mathrm{N}_{2}$-adszorpciós mérések alapján meghatároztam a minták fajlagos felületét $\left(a_{B E T}^{S}\right)$. A kapott eredményeket az 5. táblázatban foglaltam össze. A kiindulási $\mathrm{TiO}_{2}$ és HAp mintákra meghatározott fajlagos felület értékek $53 \mathrm{~m}^{2} / \mathrm{g}$ és a $116 \mathrm{~m}^{2} / \mathrm{g}$ között változtak. A $\mathrm{TiO}_{2} /$ HAp komponensek által alkotott fizikai keverék minták esetében a mért fajlagos felület értékek fokozatosan növekedtek a két érték között. Ugyanakkor a $\mathrm{TiO}_{2}$ jelenlétében előállított HAp minták (5. táblázatban „csapadékképzéssel”) esetében az 1:1 arányú összetétel közelében szignifikáns növekedés volt megfigyelhető. A 40/60 m/m\%-os $\mathrm{TiO}_{2} / \mathrm{HAp}$ összetételü kompozitra kapott fajlagos felület érték $122 \mathrm{~m}^{2} / \mathrm{g}$-nak adódott, így a mintákat további szerkezet vizsgálatnak vetettük alá.

A SAXS szórásgörbék $\ln \left(\mathrm{h}^{3} \mathrm{I}\right)-\mathrm{h}^{2}$ (Porod) diagramja alkalmas a nanokompozitok fajlagos felületének és felületi érdességének meghatározására: az aszimptotikus viselkedés sík felületre utal, éles fázishatárral (lásd: Melléklet 5. M ábra: HAp), mely a lamelláris szerkezetekre jellemző, de az elektron-sürüség ingadozása (felületi érdesség miatt) esetén az aszimptotikus viselkedéstől való pozitív eltérés figyelhető meg (lásd Melléklet 5. M ábra: $\mathrm{TiO}_{2}$ ). A SAXS módszerrel meghatározott fajlagos felület értékek $\left(a_{S A X S}^{S}\right)$, a fizikai keverék és a csapadékképzéssel előállított $\mathrm{TiO}_{2} / \mathrm{HAp}$ mintákra, jó egyezést mutattak a $\mathrm{N}_{2}$-adszorpciós mérések eredményeivel (5. táblázat).

5. táblázat. $\mathrm{A} \mathrm{HAp}, \mathrm{TiO}_{2}(\mathrm{P} 25)$ és $\mathrm{TiO}_{2} / \mathrm{HAp}$ mintákra meghatározott fajlagos felület értékek $\left(\mathrm{a}^{\mathrm{s}}\right)$ nitrogén adszorpciós (BET) és SAXS mérések alapján, valamint a mintákra meghatározott gerjesztési küszöbenergia értékek $\left(E_{g}\right)$.

\begin{tabular}{cccccc}
\hline \multirow{2}{*}{ Minta } & \multicolumn{3}{c}{ porkeverék } & \multicolumn{4}{c}{ csapadékképzéssel } \\
\cline { 2 - 6 } & $\begin{array}{c}\mathrm{a}^{\mathrm{s}} \mathrm{BET} \\
\left(\mathrm{m}^{2} / \mathrm{g}\right)\end{array}$ & $\begin{array}{c}\mathrm{a}^{\mathrm{s}} \mathrm{SAXS} \\
\left(\mathrm{m}^{2} / \mathrm{g}\right)\end{array}$ & $\begin{array}{c}\mathrm{a}^{\mathrm{s}} \mathrm{BET} \\
\left(\mathrm{m}^{2} / \mathrm{g}\right)\end{array}$ & $\begin{array}{c}\mathrm{a}^{\mathrm{s}} \mathrm{SAXS} \\
\left(\mathrm{m}^{2} / \mathrm{g}\right)\end{array}$ & $\mathrm{E}_{\mathrm{g}}(\mathrm{eV})$ \\
\hline $\mathrm{HAp}$ & 116 & 129 & 116 & 129 & - \\
$\mathrm{TiO}_{2} / \mathrm{HAp} \mathrm{20/80}$ & 89 & 101 & 83 & 107 & 3,10 \\
$\mathrm{TiO}_{2} / \mathrm{HAp} \mathrm{40/60}$ & 66 & 85 & 122 & 141 & 3,10 \\
$\mathrm{TiO}_{2} / \mathrm{HAp} \mathrm{60/40}$ & 62 & 73 & 96 & 103 & 3,10 \\
$\mathrm{TiO}_{2} / \mathrm{HAp} \mathrm{80/20}$ & 55 & 56 & 83 & 89 & 3,10 \\
$\mathrm{TiO}_{2}$ & 53 & 49 & 53 & 49 & 3,12 \\
\hline
\end{tabular}


A 40/60 m/m\%-os $\mathrm{TiO}_{2} / \mathrm{HAp}$ összetételü kompozit esetén (csapadékképzéssel elöállított $\mathrm{TiO}_{2} /$ HAp) kaptuk a legnagyobb fajlagos felület értéket, mely ebben az esetben $141 \mathrm{~m}^{2} / \mathrm{g}$-nak adódott. Az elöállított $\mathrm{TiO}_{2} / \mathrm{HAp}$ minták (mind a két sorozat) esetén a gerjesztési küszöbenergia $\left(E_{g}\right)$ értékét az előzetesen meghatározott diffúz-reflexiós spektrumok (Melléklet, 6. M ábra) alapján, KubelkaMunk módszerrel határoztam meg. Köszönhetően annak, hogy az elöállított $\mathrm{TiO}_{2} / \mathrm{HAp}_{\text {minták }}$ (mind a két sorozat esetén) $\mathrm{TiO}_{2}$ fotokatalizátort tartalmaztak azok gerjesztési küszöbenergia $\left(E_{g}\right)$ értékei, a HAp kivételével, 3,10 eV-nak adódtak (5. táblázat), a kiindulási $\mathrm{TiO}_{2} \mathrm{P} 25$ esetén ez az érték 3,12 eV. A HAp minta nem rendelkezett abszorbancia csúccsal a vizsgált hullámhossztartományban (350-500 nm).

Felhasználva az előzőekben bemutatott $\mathrm{TiO}_{2} / \mathrm{HAp}$ kompozit fotokatalizátor mintákat olyan $\mathrm{TiO}_{2} / \mathrm{HAp} /$ polimer vékonyrétegeket készítettem, melyekben a p(EA-co-MMA) polimer kötőanyag minden esetben $40 \mathrm{~m} / \mathrm{m} \%$-ban volt jelen a kompozitokban, még a szervetlen töltőanyagot $\mathrm{a} \mathrm{TiO}_{2} /$ HAp keverék adta és azok aránya rendre 0/60, 12/48, 24/36, 36/24, 48/12 és 60/0 m/m\% volt a filmekben.

A 65. ábrán a $\mathrm{TiO}_{2} / \mathrm{HAp} / \mathrm{p}(\mathrm{EA}-\mathrm{co}-\mathrm{MMA})$ vékonyrétegekről készült SEM képek arról adnak információt, hogy a $\mathrm{TiO}_{2} / \mathrm{HAp}$ arány erősen befolyásolta a hibrid vékonyrétegek felületi morfológiáját. Nagy HAp-tartalom mellett (65. ábra: $60 \%$, 48 \% és $36 \%$ HAp) a vékonyrétegek érdesebb felületi morfológiát mutattak, mint az alacsonyabb $24 \%, 12 \%$ és $0 \%$ HAp-tartalmú vékonyrétegek esetén.
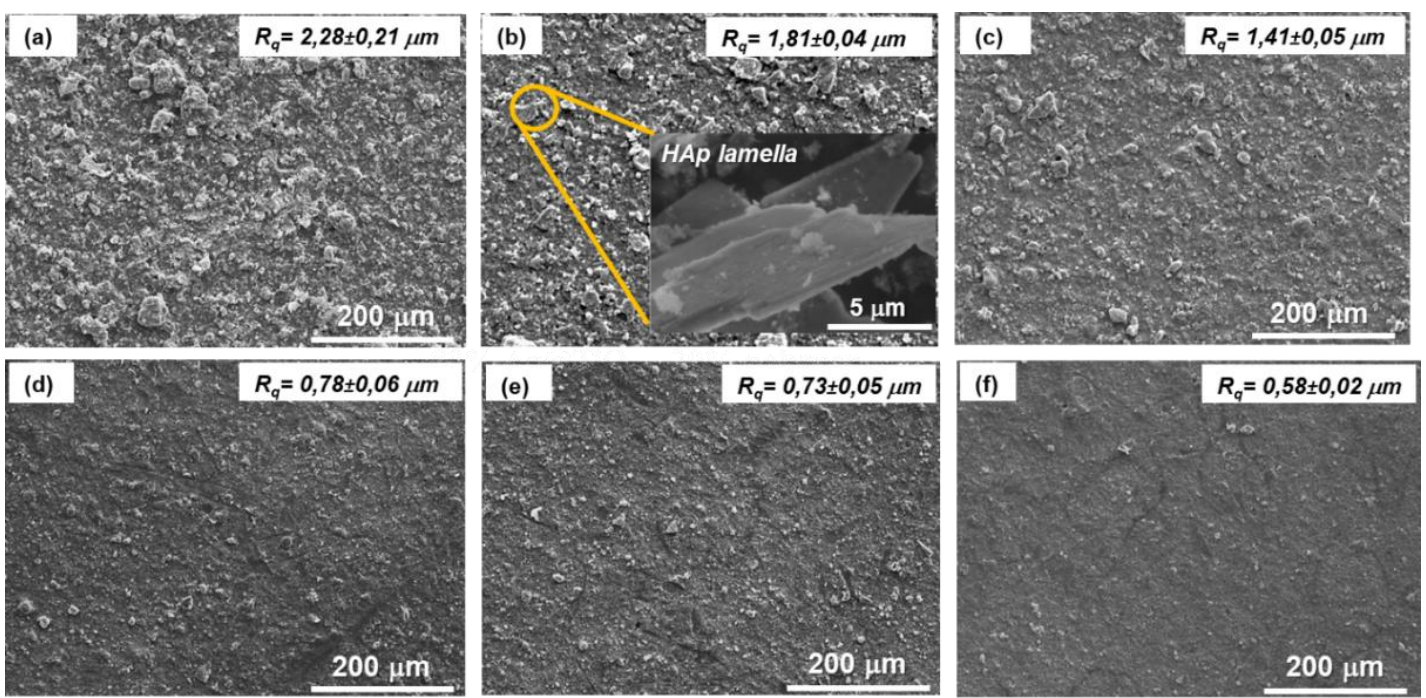

65. ábra. A 60/40 m/m\% töltőanyag/ p(EA-co-MMA) aránnyal rendelkező filmekről készült reprezentatív SEM felvételek. A filmekben a $\mathrm{TiO}_{2} / \mathrm{HAp}$ szervetlen töltőanyag összetétele: 0/60 (a), $12 / 48$ (b), 24/36 (c), 36/24 (d), 48/12 (e) és $60 / 0 \mathrm{~m} / \mathrm{m} \%$ (f).

Profilometriás mérések alátámasztották a SEM mérések során kapott eredményeket, a tisztán HAp tartalmú polimer réteg (65. (a) ábra) esetén $R_{q}=2,28 \pm 0,21 \mu \mathrm{m}$ érdességgel rendelkezett. A 
$\mathrm{TiO}_{2}$-tartalom növelésével (b, c) a hibrid rétegek érdessége csökken $\left(R_{q}=1,81 \pm 0,04 \mu \mathrm{m}, 1,41 \pm\right.$ $0,05 \mu \mathrm{m})$, és a 48 és $60 \mathrm{~m} / \mathrm{m} \% \mathrm{TiO}_{2}$-tartalmú hibrid rétegek viszonylag sima felületet mutatnak $\left(R_{q}=\right.$ $0,73 \pm 0,05 \mu \mathrm{m}$ és $0,58 \pm 0,002 \mu \mathrm{m})$. A kapott eredmények magyarázatául az szolgál, hogy a HAp lamellák fellazítják a $\mathrm{TiO}_{2} /$ polimer film réteget, mely a $\mathrm{TiO}_{2} / \mathrm{HAp}$ keverék töltőanyag szintézismódszerből kifolyólag a jól diszpergált $\mathrm{TiO}_{2}$ részecskék a biokompatibilis HAp lamellák felületén találhatók. A 65. ábrán látható beillesztett SEM kép egyetlen mikrométeres HAp lamellát mutat be a felületi $\mathrm{TiO}_{2}$ részecskékkel. A biokompatibilis $\mathrm{HAp}$ mikrolamella tehát a $\mathrm{TiO}_{2}$ fotokatalizátor nanorészecskék hordozófelületeként szolgál, és biztosítja a magas fotokatalizátor diszpergálhatóságát és a felületi hozzáférhetőségét. Az alacsonyabb HAp-tartalom $(\mathrm{d}-\mathrm{f})$ esetén a polimer alapú hibrid filmek felületén súrlódások és/vagy repedések tapasztalhatók. Ez a viszonylag gyors szárítási folyamatnak köszönhető, mert a vékony rétegek vízzel történő elpárologtatása hőlégfúvóval történt a filmképző folyamat során.

A 66. ábrán a polimer alapú hibrid rétegről készített SEM-EDX felvételeket láthatjuk, HAp hiányában (a) és jelenlétében (b). A felvételeken piros színnel jelöltem a Ti elemeloszlását a vizsgált hibrid rétegekben. A különbség a két minta között egyértelmủen látható. A HAp lamellák hiányában $\left(60 \% \mathrm{TiO}_{2} / 40 \% \mathrm{p}(\mathrm{EA}-\mathrm{co}-\mathrm{MMA})\right.$ vékonyrétegben) a $\mathrm{P} 25 \mathrm{TiO}_{2}$ részecskék aggregátumokat képeztek (66. (a) ábra), azonban a HAp jelenlétében (36\% $\mathrm{TiO}_{2} / 24 \% \mathrm{HAp} / 40 \%$ p(EA-co-MMA) vékonyrétegben) a lamellák a növelt felületi érdességen túl biztosították a magas fotokatalizátor

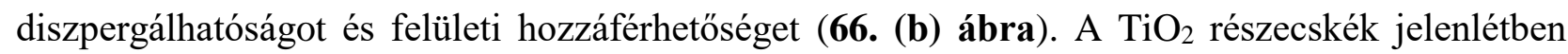
előállított HAp minta, majd az ebből előállított $\mathrm{TiO}_{2} / \mathrm{HAp} / \mathrm{p}$ (EA-co-MMA) hibrid vékonyrétegben a $\mathrm{TiO}_{2}$ eloszlása homogénebb és egyenletesebbnek bizonyult.

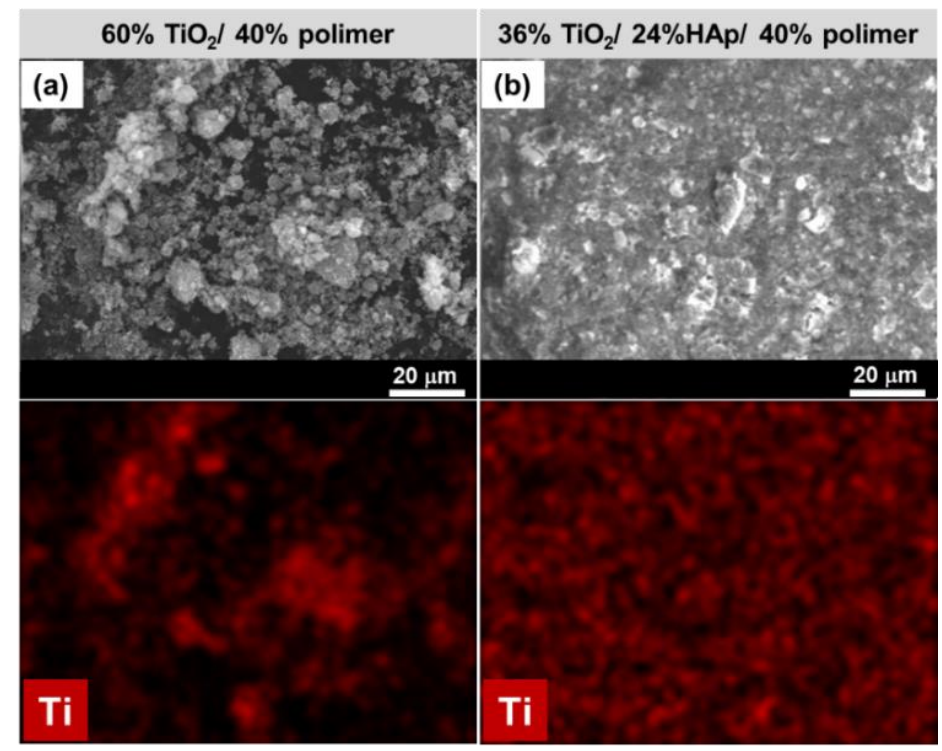

66. ábra. A kompozit filmek reprezentatív SEM- EDX felvételei HAp lamellák hiányában (60\% $\mathrm{TiO}_{2} / 40 \%$ p(EA-co-MMA)) (a) és jelenlétében (36\% $\mathrm{TiO}_{2} / 24 \% \mathrm{HAp} / 40 \%$ p(EA-co-MMA)) (b). 
4.4.3 A HAp lamellák szinergikus hatása a $\mathrm{TiO}_{2} / \mathrm{p}(\mathrm{EA}-\mathrm{co}-\mathrm{MMA})$ vékonyrétegek fotokatalitikus tulajdonságaira

A fentiekben bemutattam, hogy a HAp lamellák egyértelmúen hatással voltak a polimer alapú kompozit filmek szerkezetére és a lamellás struktúrának köszönhetően a HAp tartalmú rétegek lazább, nyitottabb és pórusossabb szerkezettel rendelkeznek. Ennek a feltételezett szerkezetnek az igazolására a HAp-tartalmú vékonyrétegek adszorpciós kapacitását összehasonlítottam a HAp nélküli, tisztán $\mathrm{TiO}_{2} /$ polimer filmmel. A teszt során a két vékonyréteget $10 \mathrm{mg} / \mathrm{L}$-es metilénkék vizes oldatába merítettem 2 órán keresztül. A 67. ábrába beillesztett fotó arról szolgáltat információt, hogy az elszíneződés mértéke sokkal nagyobb volt a HAp-ot tartalmazó film esetében. Ez egyértelműen jelzi a HAp-tartalmú vékonyrétegek jobb adszorpciós képességét, a film fokozott hidrofil jellegét, továbbá a vékonyréteg inkompakt porózus szerkezetének köszönhetően, növelt hozzáférhetőséget jelent a fotokatalizátor részecskékhez.

$\mathrm{A} \mathrm{TiO}_{2} / \mathrm{HAp} / \mathrm{p}$ (EA-co-MMA) kompozit vékonyrétegek fotokatalitikus tulajdonságát szilárd/gáz határfelületen végeztem etanol tesztmolekula fotodegradációját vizsgálva, LED-típusú $\left(\lambda_{\max }=405\right.$ $\mathrm{nm}$ ) fényforrás alkalmazása mellett (lásd 3.3.14. fejezetben). A gázkromatográfiás mérések során az etanol modellmolekula koncentrációbeli változását vizsgáltam. A 67. ábra az etanol koncentrációjának relatív csökkenését szemlélteti a növekvő bevilágítási idő függvényében.

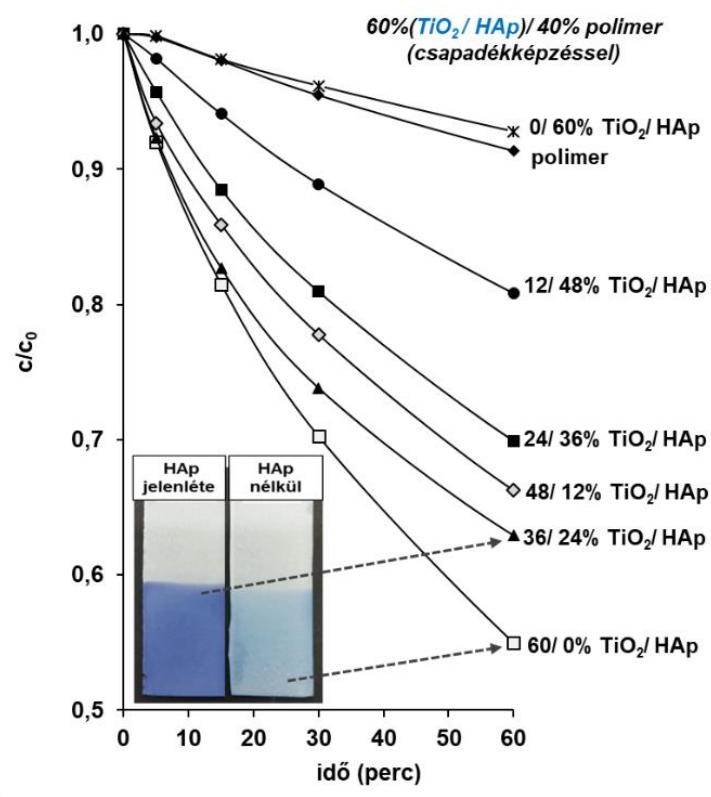

67. ábra. Az etanol modellmolekula $S / G$ határfelületen történő fotodegradációja a $40 \mathrm{~m} / \mathrm{m} \%$ polimerrel rendelkező kompozit filmeken. A HAp/ $\mathrm{TiO}_{2}$ arány szisztematikusan változott a kompozit rétegekben. A beszúrt kép a metilénkék festékmolekulák adszorpcióját mutatják be HAp jelenléte, ill. mellőzés esetén a kompozit rétegből (szórás: < $5 \%$ ).

A kapott bontásgörbék alapján elmondható, hogy a tiszta polimer filmen, ill. a $\mathrm{TiO}_{2}$-ot nem tartalmazó HAp/ p(EA-co-MMA) kompoziton elhanyagolható volt a fotodegradáció mértéke, 
ugyanakkor a $\mathrm{TiO}_{2} / \mathrm{HAp}$ kompozit katalizátorokat tartalmazó hibrid vékonyrétegek, 60 perc megvilágítási idő elteltével, a kiindulási $0,35 \mathrm{mM}$-os EtOH jelentős mennységét fotooxidálták. A hibrid vékonyrétegekben a növekvő $\mathrm{TiO}_{2}$-tartalom az EtOH fotoxidációs sebességének növekedését eredményezte, azonban a $36 \mathrm{~m} / \mathrm{m} \%$-os $\mathrm{TiO}_{2}$-tartalmú minta több modellmolekulát bontott, mint a $48 \mathrm{~m} / \mathrm{m} \%$-os minta. Ennek feltételezett oka a fentebb leírt porózus szerkezet és a jobb fotokatalitikus felületi hozzáférhetőség lehet.

A $\mathrm{TiO}_{2} / \mathrm{HAp}$ tartalmú vékonyrétegek fotokatalitikus vizsgálata során szinergikus hatás jelentkezett, mely a következő egyenlet (19.) segítségével számítható ki:

$$
\text { szinergikus hatás }=\left(\frac{\Delta c_{\text {kompoziton mért EtOH }}}{w_{1} \Delta c_{E t O H, T i O 2}}\right) \times 100
$$

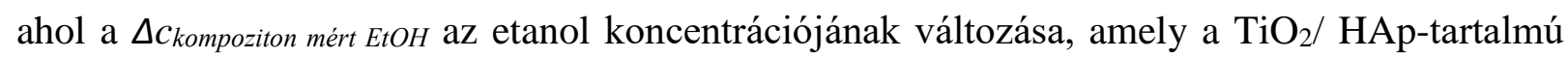
hibrid vékonyrétegek felületén jelentkezett 60 perces megvilágítási idő elteltével. A katalizátor vékonyrétegek szinergikus hatásának meghatározására választott referencia a tiszta $\mathrm{TiO}_{2}(\mathrm{P} 25)$ által mért etanol koncentráció $\left(\Delta c_{E t O H, T i O 2}\right)$ csökkenése volt. Mivel a kompozitok növekvő $\mathrm{TiO}_{2}-$ tartalommal rendelkeztek, így a kompozitok különböző $\mathrm{TiO}_{2}$-tartalmának $\left(w_{1}\right)$ megfelelően

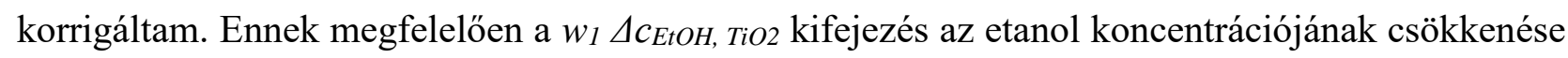
60 perc megvilágítási idő elteltével a tiszta $\mathrm{TiO}_{2}$ fotokatalizátor tömegaránya ( $\left.\mathrm{w}_{1}\right)$ alapján. Ezzel a számítással tehát azt adtam meg, hogy a $60 \mathrm{~m} / \mathrm{m} \%$-nyi $\mathrm{TiO}_{2} / \mathrm{HAp}$ kompozit fotokatalizátor mennyivel több etanolt fotodegradált, mintha a polimerben csak a tiszta $\mathrm{TiO}_{2}$ lenne jelen.

$\mathrm{Az}$ etanol fotodegradációja alapján, a számított értékeket összehasonlítva a mért adatokkal, szinergikus hatás jelentkezett (68. ábra).

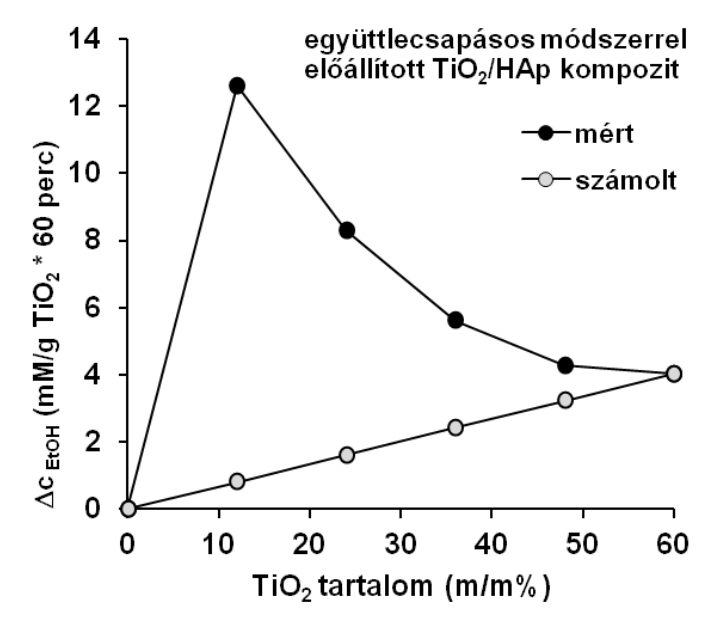

68. ábra. Az elbontott EtOH koncentráció változása a kompozit $\mathrm{TiO}_{2}$ tartalmának függvényében. A kompozit rétegekben a katalizátor $\left(\mathrm{HAp} / \mathrm{TiO}_{2}\right.$ keverék) $60 \mathrm{~m} / \mathrm{m} \%$ és a p(EA-co-MMA) 40 $\mathrm{m} / \mathrm{m} \%$. 
A kapott eredmények alapján láthatjuk, hogy alacsonyabb $\mathrm{TiO}_{2}$ fotokatalizátor tartalom mellett (12-36 m/m\%) nagyobb fotoxidációs hatékonyság (139-313\%) érhető el. Tehát, fotokatalitikus mérésekkel igazoltam, hogy a hibrid vékonyrétegekben a $\mathrm{TiO}_{2}$ fotokatalizátor hozzáférhetősége növelhető a HAp tartalomnak köszönhetően.

A fentieken túl a HAp lamellák jelenlétének még egy előnyös tulajdonsága megmutatkozott a tesztek során. Fontos megjegyezni, hogy a tisztán $\mathrm{TiO}_{2}$ tartalmú hibrid vékonyrétegek esetén nem csak a fotooxidálni kívánt modell molekulát, hanem a rögzítő polimer mátrixot is fotodegradáljuk. A polimer kötőanyag nem kívánatos fotodegradációja azonban visszaszorítható, annak köszönhetően, hogy a hibrid réteg nem csak fotokatalizátort, hanem fotokatalitikusan inaktív HAp lamellákat is tartalmaz. A 69. ábra a vékonyrétegekben lévő rögzítő polimer fotodegradációjának mértékét mutatja be a tisztán fotokatalizátor tartalmú $\left(60 \% \mathrm{TiO}_{2} / 40 \%\right.$ p(EA-co-MMA)), illetve a HAp-ot tartalmazó (36\% $\mathrm{TiO}_{2} / 24 \%$ HAp/ 40\% p(EA-co-MMA)) hibrid réteg esetén.

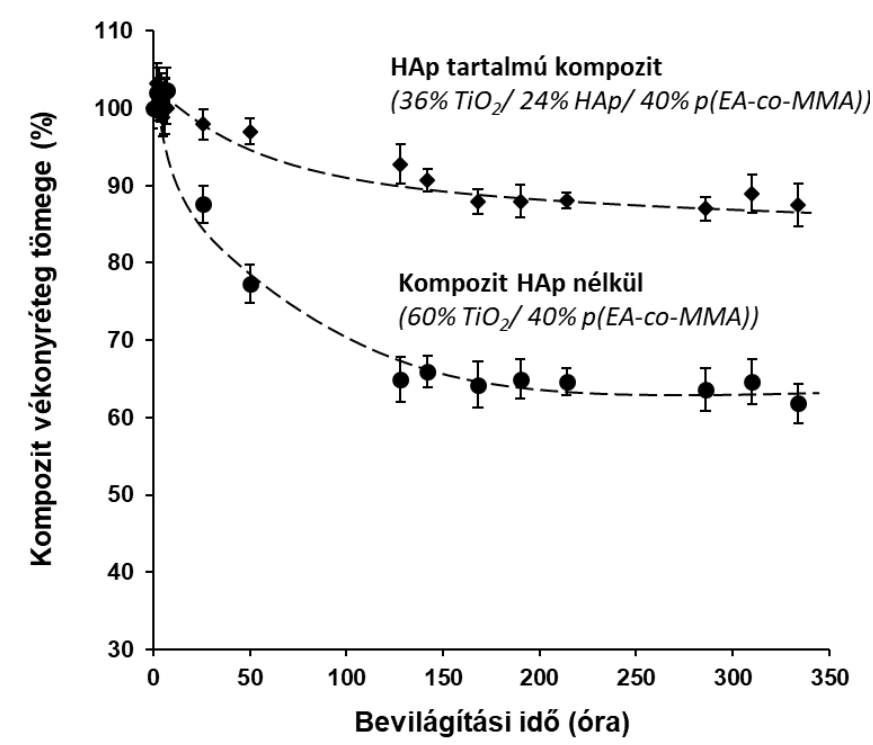

69. ábra. A vékonyrétegben lévő kötő polimer degradációjának vizsgálata HAp lamellák jelenlétében és mellőzése esetén. Alkalmazott fényforrás: LED $\left(\lambda_{\max }=405 \mathrm{~nm}\right)$.

A HAp jelenléte a kötőanyagban a p(EA-co-MMA) polimer mérsékelt fotodegradációját okozta. Ennek oka, hogy az apatittal rendelkező hibrid vékonyréteg esetében, a felületi $\mathrm{TiO}_{2}$ részecskék nem érintkeztek közvetlenül a polimer kötőanyaggal, így a szerves kötőanyag nem fotooxidálódott. Az inert HAp lamellák távtartó szerepét egyszerü gravimetriás méréssel bizonyítottam. A vizsgálat során a polimer alapú kompozit filmeket (HAp jelenlétében vagy annak hiányában) 405 nm-es LEDtípusú fényforrással világítottam meg, hosszú ideig (336 óra, két hét) szobahőmérsékleten, és a vékonyrétegek tömegét adott idöközönként mértem. A csak $\mathrm{TiO}_{2}$-ot tartalmazó polimer alapú hibrid 
film tömegvesztesége 120 órás megvilágítási idő után $\sim 35 \mathrm{~m} / \mathrm{m} \%$ volt, míg a HAp-tartalmú film esetében ez az érték a mért időintervallumban csak $\sim 15 \mathrm{~m} / \mathrm{m} \%$ volt.

Tehát HAp lamellák hiányában a $\mathrm{TiO}_{2} / \mathrm{p}(\mathrm{EA}-\mathrm{co}-\mathrm{MMA})$ hibrid film elvesztette majdnem a teljes polimer-tartalmát (40 m/m\%). Ez azt bizonyítja, hogy a HAp lamellák hibrid rétegben távtartóként szolgálnak, megakadályozza a $\mathrm{TiO}_{2}$ közvetlen érintkezését a polimerrel, így jelentősen csökkenthető kötő polimer lebontásának lehetősége. 


\section{5. Összefoglalás}

Doktori munkám során funkcionális kompozit anyagokat, valamint azok alkotó komponenseit állítottam elö, vizsgáltam az előállított rendszerek szerkezeti tulajdonságait, és alkalmazási lehetőségeit.

A kialakított kompozitok folytonos fázisát különböző hidrofilitással rendelkező poliakrilátok adták, amelyben lamellás szerkezettel rendelkező réteges kettős hidroxidot (LDH), réteges kettős oxidot (LDO), montmorillonitot, ill. a hidroxiapatitot (HAp) oszlattam el.

Csapadékképződéssel járó reakcióval sikeresen állítottam elő réteges szerkezettel rendelkező 2:1 Mg/Al-kettős hidroxidot (2:1 Mg/Al-LDH), amely nagy fajlagos felülettel (114,96 $\left.\pm 0,48 \mathrm{~m}^{2} / \mathrm{g}\right)$ és pozitív (+641 mmol/ 100 g) felületi töltéssel rendelkezett. Az LDH ezen tulajdonásgait kihasználva, gyomorfekély ellenes kinurénsav molekulákat interkaláltam a rétegek közé, ezáltal KYNA/ LDH interkalációs nanokompozitot előállítva. Az anionos KYNA molekulák rétegbeli interkalációját FTIR mérésekkel igazoltam, az XRD mérések alapján pedig megállapítottam, hogy azok paraffinszerü monomolekulás elrendeződést mutatnak a lamellák között. Az adszorpciós/ interkalációs eredmények alapján a kompozit kb. $12 \mathrm{~m} / \mathrm{m} \%$-os KYNA tartalommal rendelkezett, melyet a termoanalitikai mérések is alátámasztottak $(13,9 \mathrm{~m} / \mathrm{m} \%)$. Bemutattam, hogy in vitro körülmények között, a KYNA/ LDH kompozit rendszer alkalmas pH-függő hatóanyag kioldódásra. Gravimetriás, illetve röntgendiffrakciós mérésekkel igazoltam, hogy a mesterséges gyomornedv $\mathrm{pH}=1,5$ értékén a 2:1 Mg/Al-LDH hordozó $\mathrm{t}=6$ óra alatt teljesen feloldódik, amely oldódási folyamatnak köszönhetően az LDH-ba interkalált kinurénsav egy késleltetett hatóanyag-leadási profilt mutatott a szabad KYNA-hoz képest. Jelentős hatóanyag visszatartás volt észlelhető, négy óra elteltével 18 \% kinurénsav oldódott ki a KYNA/ LDH nanohibrid rendszerből.

A szintéziskörülmények módosításával a hagyományos, lamellás szerkezetü LDH mellett gömbszerü morfológiával rendelkező LDH-t is előállítottam. Elektronmikroszkópos felvételekkel bemutattam, hogy a 25,31 $\pm 2,34 \mu \mathrm{m}$-es átmérővel rendelkező LDH gömbökben a lamellák sugárirányú elrendeződése szférikus morfológiát eredményez. Részletesen vizsgáltam a szintéziskörülmények hatását a kapott termék tulajdonságaira és megállapítottam, hogy karbamid jelenlétében, $\mathrm{pH}=3$ értéken, közel $100{ }^{\circ} \mathrm{C}$-on egy hétig öregítve gömbszerü morfológiával rendelkező ZnMgAl-LDH állítható elő. Azt is megállapítottam, hogy a gömbi LDH felületi töltése $\mathrm{pH}$ függő tulajdonságokat mutat. Alacsony $\mathrm{pH}$ értékeknél $(\mathrm{pH}<4)$ nagy fajlagos felületi töltéssel rendelkezik (+273 mmol/ $100 \mathrm{~g})$, míg magasabb pH értékeknél $(\mathrm{pH}>4)$ elveszti pozitív töltését.

A töltéskompenzáción alapuló heterokoagulációs kompozit előállításához a változó felületi töltéssel rendelkező LDH mellé montmorillonit agyagásvány lamellákat választottam, hiszen ennek az inert biokompatibilis anyagnak a felületi töltése negatív az általam vizsgált $\mathrm{pH}(=3-6)$ 
tartományon. Reológiai mérések alapján igazoltam, hogy alacsony $\mathrm{pH}$ értékeken $(\mathrm{pH}<4,5)$ a pozitív felületi töltéssel rendelkező LDH gömbök elektrosztatikus kölcsönhatásokat alakítanak ki a negatív felületi töltéssel rendelkező $\mathrm{Ag}^{0}$-montmorillonit lamellákkal, koherens gélszerkezetet képezve. Ezt a mért folyáshatár értékek is alátámasztották, $\mathrm{pH}=3$ értéken az $\mathrm{LDH} / \mathrm{Ag}^{0}$-montmorillonit $(25 / 75$ m/m\%) kompozit esetén 9,90 Pa-nak adódott. A pozitív töltésü LDH gömbök jelenléte nélkül azonban az ugyanilyen koncentrációval rendelkező $\mathrm{Ag}^{0}$-montmorillonit, illetve Na-montmorillonit szuszpenziók mindössze 0,184 és $2,307 \mathrm{~Pa}$ folyáshatár értékkel rendelkeztek. A pH érték növelésével $(\mathrm{pH}=6)$ ez a gélszerkezet szétesett, az $\mathrm{LDH} / \mathrm{Ag}^{0}$-montmorillonit kompozit inkoherens szolként viselkedett, ami az LDH részecskék töltésének elvesztésével volt magyarázható. A szolgél átmenettel járó szerkezetváltozást SAXS mérésekkel is alátámasztottam, mely mérések szintén igazolták, hogy a pH csökkenésével az LDH/ $\mathrm{Ag}^{0}$-montmorillonit (25/75 m/m\%) kompozit esetén egy rendezettebb struktúra alakul ki, ugyanis a gélképzés során $(\mathrm{pH}: 6 \rightarrow 3)$ a felület fraktál értéke 3,36-ról 2,59-re csökkent, jelezve a heterokoagulációs jelenség által okozott felületi strukturáltság növekedését.

Bemutattam, hogy a koherens szerkezet szétesésével az $\mathrm{Ag}^{0}$-montmorillonit felületén immobilizált $\mathrm{Ag}^{0}$-nanorészecskék hozzáférhetősége jelentősen megnő és ezáltal a minta antibakteriális tulajdonságokra tesz szert. Az eredmények alapján az $\mathrm{Ag}^{0}$-montmorillonit kompozit már kis koncentrációban (25 ppm-es $\mathrm{Ag}^{0}$-mont. szuszpenzió) képes volt inaktiválni az Escherichia coli tesztbaktériumok által képzett bakteriális filmet $1,79 \times 10^{6} \mathrm{CFU} / \mathrm{cm}^{2}$ felületi baktérium koncentráció mellett.

A gömbi morfológiájú LDH $600{ }^{\circ} \mathrm{C}$-on történő kalcinálásával fotokatalitikus tulajdonságokkal rendelkező LDO-t sikerült előállítani, mely $\sim 12$ m/m\%-os ZnO tartalmának köszönhetően egy érdes felülettel rendelkező és UV-fénnyel gerjeszthető strukturált oxid részecskéket eredményezett. A kalcinálás hatására a kiindulási LDH szerkezete nem omlott össze, fajlagos felülete enyhén nőtt $\left(12,84 \mathrm{~m}^{2} / \mathrm{g}\right.$-ról 14,75 m²/g-ra) és az optikai mérések alapján a minta gerjesztési küszönebergiája $3,2 \mathrm{eV}$ - nak adódott.

Az LDO részecskék fotokatalitikus és érdes felületi tulajdonságainak kiaknázása céljából polimer alapú kompozit vékonyrétegeket preparáltam porlasztásos filmképzéssel, ahol részecskék felületi rögzítését kis felületi energiával $\left(\gamma_{\mathrm{s}}{ }^{\text {tot }}=28,0 \pm 3,91 \mathrm{~mJ} / \mathrm{m}^{2}\right)$ rendelkező poli-perfluorodecilakrilát (p(PFDAk)) polimerrel biztosítottam. A kompozit filmek preparálása során szisztematikusan változtattam az $\mathrm{LDO} / \mathrm{p}(\mathrm{PFDAk})$ arányt a vékonyrétegekben; a filmek fotokatalitikus sajátságát pedig szilárd/folyadék határfelületen jellemeztem. A modellreakcióban benzoesav fotodegradációját követtem nyomon fotometriás mérések által, UV-A fényforrás $\left(\lambda_{\max }=365 \mathrm{~nm}\right)$ alkalmazása mellett. Megállapítottam, hogy négy óra bevilágítási idő elteltével, a kiindulási polimer 
réteg nem mutat fotokatalitikus aktivitást, szemben az LDO tartalmú kompozit rétegekkel, amelyek közül a $80 \mathrm{~m} / \mathrm{m} \%$ LDO tartalmú kompozit film $\left(\mathrm{A}=25 \mathrm{~cm}^{2}\right)$ esetében 240 perces fotokatalitikus mérések során, a kiindulási 0,17 g/L-es benzoesav vizes oldat koncentrációja 24 \%-kal csökkent.

Bemutattam, hogy az LDO/ p(PFDAk) arány változtatásával a filmek érdessége is szabályozható; a kiindulási sík polimer filmre kapott érdesség $\left(R_{q}=0,002 \pm 0,0002 \mu \mathrm{m}\right)$ fokozható az LDO tartalom növekedésével egészen 15,30 $\pm 2,04 \mu \mathrm{m}$-ig. A peremszög mérések alapján az LDO részecske tartalom növelésével a kialakított rétegek látszólagos felületi szabadenergia értékei is változtak. A kiindulási fluoropolimerre $\left(0 \mathrm{~m} / \mathrm{m} \%\right.$ LDO tartalom) jellemző $\gamma_{\mathrm{s}}{ }^{\text {tot }}=28,0 \pm 3,91 \mathrm{~mJ} / \mathrm{m}^{2}$ felületi szabadenergia érték egészen $\gamma_{\mathrm{s}}{ }^{\text {tot }}=2,7 \pm 0,65 \mathrm{~mJ} / \mathrm{m}^{2}$-ig csökkenthető, mely a $80 \mathrm{~m} / \mathrm{m} \% \mathrm{LDO}$ tartalom esetén valósult meg. A felület nedvesedési tulajdonságait vizsgálva bemutattam, hogy a kiindulási sík felületü fluoropolimer rétegre jellemző $\Theta_{\mathrm{w}}=105,6^{\circ} \pm 0,76^{\circ}$-os peremszög érték növelhető volt a hozzáadott részecske tartalommal. A 80 és $90 \mathrm{~m} / \mathrm{m} \%$ LDO tartalmú polimer rétegek esetén szuperhidrofób tulajdonságú felületet sikerült kialakítani, mely során a mért peremszög érték $156,3^{\circ} \pm 1,88^{\circ}$ és $157,1^{\circ} \pm 1,53^{\circ}$-nak adódott, azaz a felületi érdesség a felület jellegét, nedvesedési tulajdonságát fokozta.

Munkám során bemutattam, hogy az LDO töltőanyag alkalmazásával nemcsak fotokatalitikus és szuperhidrofób felület alakítható ki, hanem ezen túlmenően a kialakított kompozit réteg antibakteriális tulajdonságokkal is rendelkezik. Kristályibolya sejtfestési eljárás eredményei alapján megállapítottam, hogy az egyre az növekvő LDO részecske tartalommal a Staphylococcus aureus, Escherichia coli és Pseudomonas aeruginosa tesztbaktériumok adhéziója nőtt a felületen. Elektronmikroszkópos felvételekkel igazoltam, hogy a 0,6-2 $\mu \mathrm{m}$-es mérettel rendelkező baktériumok a kétkomponensű rétegek esetében a hidrofil LDO lamellák felületén helyezkednek el, azaz a baktériumok jobban preferálták a hidrofil, nagy energiájú felületet a hidrofób fluoropolimerrel szemben. A mikrobiológiai tesztek igazolták, hogy 120 perc megvilágítási idő elteltével az élő baktérium sejtek száma $46 \%$-kal csökkent.

Végül azt is bemutattam, hogy a biokompatibilis és lamelláris szerkezetü HAp töltőanyag alkalmazásával olyan $\mathrm{TiO}_{2}$ tartalmú poliakrilát alapú kompozit bevonatok preparálhatóak, melyek megnövelt fotokatalitikus hatásfokuk mellett a kompozit réteg tartósságát is növelték.

Sikeresen állítottam elő $116 \mathrm{~m}^{2} / \mathrm{g}$ fajlagos felülettel és lamellás szerkezettel valamint biokompatibilis tulajdonságokkal rendelkező hidroxiapatit (HAp) lamellákat, melyek felhasználásával $\mathrm{TiO}_{2} / \mathrm{HAp} / \mathrm{p}(\mathrm{EA}-\mathrm{co}-\mathrm{MMA})$ alapú háromkomponensű vékonyrétegeket preparáltam. 120 óra LED-típusú fényforrással $\left(\lambda_{\max }=405 \mathrm{~nm}\right)$ történő bevilágítási idő elteltével, HAp lamellák jelenlétében a $\left(36 \% \mathrm{TiO}_{2} / 24 \% \mathrm{HAp} / 40 \%\right.$ p(EA-co-MMA)) kompozit rétegben a polimer degradációja mindössze $15 \%$ volt, míg HAp lamellát nem tartalmazó $\left(60 \% \mathrm{TiO}_{2} / 40 \%\right.$ 
p(EA-co-MMA)) kompozitokban a polimer degradációja elérte a 35 \%-ot. Az eredmények alapján elmondható, hogy a lamellás szerkezetü HAp alkalmas komponensként szolgálhat a fotokatalizátor/ polimer vékonyrétegek fotodegradációjának visszaszorítására azáltal, hogy inert „távtartóként” van jelen a fotokatalizátor részecskék és a rögzítő szerves polimer mátrix között. Emellett a HAp lamellák jelenléte a kompozit réteg fotokatalitikus tulajdonságait is fokozta, ui. alacsonyabb $\mathrm{TiO}_{2}$ fotokatalizátor tartalom mellett (12-36 m/m\%) 139-313\%-al nagyobb fotoxidációs hatékonyság volt elérhető. A jelentkező szinergikus hatás feltehetően annak köszönhető, hogy a $\mathrm{TiO}_{2} / \mathrm{HAp}^{\prime}$ p(EA-co-MMA) vékonyrétegben a $\mathrm{TiO}_{2}$ részecskék a HAp lamellák felületén homogénen eloszlatva helyezkedtek el, a kompozit mátrix felületén, mely nagyobb hozzáférhetőséget biztosított a felületen adszorbeálódó molekuláknak is. 


\section{Summary}

\section{Synthesis and characterization of functional composite systems and their application possibilities}

During my Ph.D. work I have synthesized functional composite materials and their components. I have investigated the structural properties of the systems and the possibilities of their application.

The continuous phase of the prepared composites was provided by polyacrylates with different hydrophilicity, in which layered double hydroxide (LDH), layered double oxide (LDO), montmorillonite and hydroxyapatite (HAp) was dispersed.

By co-precipitation method, 2:1 Mg-Al layered double hydroxide (2:1 Mg/Al-LDH) was successfully synthesized, with high specific surface area $\left(114.96 \pm 0.48 \mathrm{~m}^{2} / \mathrm{g}\right)$ and positive specific surface charge (+641 mmol/ $100 \mathrm{~g})$. Utilizing these properties of LDH, anti-ulcerant kynurenic acid molecules were intercalated between the layers to obtain a KYNA/ LDH intercalation nanocomposite. The intercalation of anionic KYNA guest molecules was confirmed by FT-IR measurements into the host LDH layers and their paraffin type monolayer arrangement between the lamellae was obtained from XRD measurements. Based on adsorption/ intercalation results, the composite contained $\sim 12$ wt.\% KYNA which was also confirmed by thermoanalytical measurements (13.9 wt.\%). It was shown that the KYNA/ LDH composite system is appropriate for $\mathrm{pH}$-dependent drug release under in vitro conditions. It was demonstrated by gravimetric and XRD measurements, that the prepared 2:1 Mg/Al-LDH was almost completely dissolved (in 6 hours) in the applied simulated gastric fluid media at $\mathrm{pH}=1.5$. Due to the dissolution process, the intercalated kynurenic acid in LDH showed a delayed drug release profile compared to the pure KYNA at the same $\mathrm{pH}$. Significant drug retention was observed, $18 \%$ of kynurenic acid was released from the KYNA/ LDH nanohybrid system after 4 hours.

By modifying the synthesis conditions, besides the traditional lamellar LDH, I also synthesized LDH with spherical morphology. The electron microscopic images revealed that the radial arrangement of the lamellae of LDH resulted in a spherical morphology with a diameter of $25.31 \pm$ $2.34 \mu \mathrm{m}$. The effect of the synthesis conditions on the properties of the obtained product was investigated in detail, and it was found that $\mathrm{ZnMgAl}-\mathrm{LDH}$ with spherical morphology can be synthetized in the presence of urea at $\mathrm{pH}=3$, aging for one-week at about $100{ }^{\circ} \mathrm{C}$. It was also established that the surface charge of spherical LDH shows $\mathrm{pH}$-dependent properties. At low $\mathrm{pH}$ values $(\mathrm{pH}<4)$ it has a high specific surface charge $(+273 \mathrm{mmol} / 100 \mathrm{~g})$, while at higher $\mathrm{pH}$ values $(\mathrm{pH}>4)$ it loses its positive charge. 
I have chosen montmorillonite clay lamellae with variable surface charge LDH to produce heterocoagulated composite. This clay is an inert and biocompatible material with negative surface charge in the studied $\mathrm{pH}$ range (=3-6). On the basis of rheological measurements, LDH spheres form a coherent gel structure in the presence of $\mathrm{Ag}^{0}$-montmorillonite lamellae due to electrostatic interactions at low $\mathrm{pH}$ values $(\mathrm{pH}<4.5)$. This was also confirmed by reological measurements since the obtained yield point of $\mathrm{LDH} / \mathrm{Ag}^{0}$ - montmorillonite (=25/75 w/w\%) composite was $9.90 \mathrm{~Pa}$ at $\mathrm{pH}=3$. However, these values for $\mathrm{Ag}^{0}$-montmorillonite and Na-montmorillonite suspensions were only 0.184 and $2.307 \mathrm{~Pa}$, respectively. Increasing the $\mathrm{pH}(\mathrm{pH}=6)$, this gel structure was disintegrated and the $\mathrm{LDH} / \mathrm{Ag}^{0}$-montmorillonite composite behaved as an incoherent sol, which could explain by the loss of $\mathrm{LDH}$ particle surface charge. The structural change associated with the sol-gel transition was also studied by SAXS measurements. These measurements have also shown that with the decrease of $\mathrm{pH}$, the $\mathrm{LDH} / \mathrm{Ag}^{0}-$ montmorillonite $(25 / 75 \mathrm{w} / \mathrm{w} \%)$ composite became increasingly ordered. In the course of coherent gel formation $(\mathrm{pH}: 6 \rightarrow 3)$, the surface fractal dimension decreased from 3.36 to 2.59 , indicating the coarsening of the surface due to heterocoagulation process.

I have also shown that with the disintegration of the coherent structure, the accessibility of the immobilized $\mathrm{Ag}^{0}$ nanoparticles from the surface of $\mathrm{Ag}^{0}$-montmorillonite significantly increased and thus the sample gained antibacterial properties.

Based on the results, the $\mathrm{Ag}^{0}$-montmorillonite composite was able to inactivate the bacterial film formed by Escherichia coli test bacteria $\left(1.79 \times 10^{6} \mathrm{CFU} / \mathrm{cm}^{2}\right)$ even at low concentrations (25 ppm $\mathrm{Ag}^{0}$-mont. suspension).

Using a calcination method carried out at $600{ }^{\circ} \mathrm{C}$, the spherical LDH was converted into photocatalytically active LDO particles, i.e. the oxidation of the initial LDH sample resulted a rough surface and UV- excitable oxide particle due to the presence of $12 \mathrm{wt} \% \mathrm{ZnO}$ content. As a result of calcination, the initial LDH structure did not collapse, the specific surface area slightly increased (from $12.84 \mathrm{~m}^{2} / \mathrm{g}$ to $14.75 \mathrm{~m}^{2} / \mathrm{g}$ ). The determined excitation wavelength and the calculated band gap energy values were $386 \mathrm{~nm}$ and $3.23 \mathrm{eV}$, respectively.

In order to exploit the dual photocatalytic and rough surface properties of LDO particles, polymer-based composite thin films were prepared by spray-coating technique on the surfaces of glass plates. Low surface energy poly(perfluorodecyl acrylate) [p(PFDAc)] fluoropolymer was used as a binding material for the immobilization of LDO particles. The determined surface free energy value of the pure p(PFDAc) fluoropolymer was $28.0 \pm 3.91 \mathrm{~mJ} / \mathrm{m}^{2}$. The loading of the LDO in the fluoropolymer-based hybrid layers was systematically varied between 0 and $100 \mathrm{wt} . \%$, in order to obtain thin films with varying surface roughness. The photocatalytic activities of the prepared LDO/ 
fluoropolymer layers were verified with benzoic acid (as test molecule) degradation tests under UVA light illumination $\left(\lambda_{\max }=365 \mathrm{~nm}\right)$ on solid/ liquid interface. After four hours of exposure time, the initial polymer layer didin't show photocatalytic activity compared to the LDO-containing composite layers. The photooxidation rate became more prominent above $80 \mathrm{wt} \%$ LDO content. From this LDO loading, the hybrid layers $\left(A=25 \mathrm{~cm}^{2}\right)$ photodegraded $\sim 24 \%$ of the initial $0.17 \mathrm{~g} / \mathrm{L}$ benzoic acid test molecule content during the photocatalytic measurements.

The results reveal enhancing the ratio of incorporated LDO particles from 0 to $80 \mathrm{wt} . \%$ into the hydrophobic fluoropolymer, the $R_{q}$ values continuously increased from $0.002 \pm 0.0002 \mu \mathrm{m}$ to 15.3 $\pm 2.04 \mu \mathrm{m}$.

The low surface free energy $\left(\gamma_{\mathrm{s}}{ }^{\text {tot }}=28.0 \pm 3.91 \mathrm{~mJ} / \mathrm{m}^{2}\right)$ of the smooth surface $\left(\mathrm{R}_{\mathrm{q}}=0.002 \pm 0.0002\right.$ $\mu \mathrm{m}) \mathrm{p}$ (PFDAc) polymer could be further reduced to $2.7 \pm 0.65 \mathrm{~mJ} / \mathrm{m}^{2}$ with the enhanced surface roughness $\left(\mathrm{R}_{\mathrm{q}}=15.3 \pm 2.04 \mu \mathrm{m}\right)$ obtained at $80 \mathrm{wt} . \%$ of LDO content.

Examining the wetting properties of the surface, it was demonstrated that the determined static water contact angle $\left(\Theta_{\mathrm{w}}\right)$ values for the initial flat fluoropolymer layer $\left(\Theta_{\mathrm{w}}=105.6^{\circ} \pm 0.76^{\circ}\right)$ could be increased with the embedded particle content. At 80 and 90 wt.\% LDO content, the measured $\Theta_{\mathrm{w}}$ values were $156.3^{\circ} \pm 1.88^{\circ}$ and $157.1^{\circ} \pm 1.53^{\circ}$ respectively, which means that superhydrophobic layers were obtained.

In the course of my work I have shown that by using LDO, a photocatalytic and superhydrophobic surface can be formed and moreover this composite layer obtained antibacterial properties. Based on the results of crystal violet cell staining tests, the surface adhesion of Staphylococcus aureus, Escherichia coli and Pseudomonas aeruginosa test bacteria was increased with the LDO particle content. Electron microscopy showed that the 0.6-2 $\mu \mathrm{m}$ bacteria are located on the surface of the hydrophilic LDO lamellae in the two-component layers, i.e. the bacteria preferred the hydrophilic, high energy surface instead of the hydrophobic fluoropolymer. Microbiological tests confirmed that after 120 minutes of exposure, the number of live bacterial cells decreased by $46 \%$.

Finally, I have presented that by using biocompatible and lamellar $\mathrm{HAp}$ filler, $\mathrm{TiO}_{2}$-containing polyacrylate-based composite coatings can be prepared since this filler increases their photocatalytic efficiency and also increases the durability of the composite layer. Biocompatible hydroxyapatite (HAp) with $116 \mathrm{~m}^{2} / \mathrm{g}$ specific surface area and lamellar structure was successfully prepared. HAp was used to prepare $\mathrm{TiO}_{2} / \mathrm{HAp} / \mathrm{p}$ (EA-co-MMA) ternary thin films. In the presence of HAp lamellae $\left(36 \% \mathrm{TiO}_{2} / 24 \% \mathrm{HAp} / 40 \% \mathrm{p}(\mathrm{EA}-\mathrm{co}-\mathrm{MMA})\right)$ the self photodegradation of the organic polymer part in the composite layer was only $15 \%$, while in the case of composites without HAp lamellae, the degradation was reached $35 \%$ after 120 hours of illumination with LED-light source 
$\left(\lambda_{\max }=405 \mathrm{~nm}\right)$. This proves that HAp serves as an "inert spacer" to prevent $\mathrm{TiO}_{2}$ from coming into direct contact with polymer and to suppress photodegradation of photocatalyst/ polymer thin films, so the possibility of decomposing these organic incorporation media is significantly reduced.

In addition, the presence of HAp lamellae enhanced the photocatalytic properties of the composite layer, with lower $\mathrm{TiO}_{2}$ photocatalyst content (12-36 wt.\%), 139-313\% higher photoxidation efficiency was achieved. This synergistic effect is probably due to the fact that $\mathrm{TiO}_{2}$ particles were homogeneously distributed on the surface of the HAp lamellae on the surface of the $\mathrm{TiO}_{2} / \mathrm{HAp} / \mathrm{p}$ (EA-co-MMA) composite matrix which provided greater accessibility to the adsorbing molecules on the surface. 


\section{Irodalomjegyzék}

[1] F. Hussain, M. Hojjati, M. Okamoto, R.E. Gorga; Journal of Composite Materials, 40(17) (2006) 1511-1575.

[2] K. Girija, A. Gitanjali, M. Pradeepkumar, G. R. Iyappan; International Journal for Innovative Research in Science \& Technology, 5 (2019) 32-39.

[3] A. Brent Strong; Fundamentals of Composites Manufacturing, Society of Manufacturing Engineers, 2nd ed., 2008.

[4] C.A.M. Soares, C.M.M. Soares, M.J.M. Freitas; Mechanics of Composite Materials and Structures. Springer-Science + Business Media, B.V., Portugal, 1998.

[5] M. Sahoo, R.W. Smith; Metal Science, 9(1) (1975) 217-222.

[6] T. Sathishkumar, S. Satheeshkumar; J. Naveen, Journal of Reinforced Plastics and Composites, 33(13) (2014) 1258-1275.

[7] H.L. Tekinalp, V. Kunc, G.M. Velez-Garcia, C.E. Duty, L.J. Love, A.K. Naskar, C.A. Blue, S. Ozcan; Composites Science and Technology, 105 (2014) 144-150.

[8] C.E. Bakis, L.C. Bank, F.ASCE; V.L. Brown, M.ASCE; E. Cosenza, J. F. Davalos, A.M.ASCE; J.J. Lesko, A. Machida, S.H. Rizkalla, F.ASCE; T.C. Triantafillou, M.ASCE; Journal of Composites for Construction, 6(2) (2002) 73-87.

[9] C. Sanchez, B. Julián, P. Belleville, M. Popall; Journal of Materials Chemistry, 15(35-36) (2005) 3559.

[10] H. Fischer; Materials Science and Engineering: C, 23(6-8) (2003) 763-772.

[11] P. Maiti, M. Okamoto; Macromol. Mater. Eng., 288 (2003) 440-445.

[12] A. Okada, M. Kawasumi, I. Tajima, T. Kurauchi, O. Kamigaito; Journal of Applied Polymer Science, 37 (1989) 1363-1371.

[13] M. Kawasumi, N. Hasegawa, M. Kato, A. Usuki, A. Okada; Macromolecules, 30(20) (1997) 63336338.

[14] J.S. Bergman, H. Chen, E.P. Giannelis, M.G. Thomas, G.W. Coates; Chem. Commun., (1999) 2179-2180.

[15] X. Fu, S. Qutubuddin; Materials Letters, 42 (2000) 12-15.

[16] C. Wan, X. Qiao, Y. Zhang, Y. Zhang; Polymer Testing, 22 (2003) 453-461.

[17] L.W. Jang, C.M. Kang, D.C. Lee; Part B: Polym. Phys., 39 (6) (2001) 719.

[18] M. Okamoto, S. Morita, H. Taguchi, Y.H. Kim, T. Kotaka, H. Tateyama; Polymer, 41 (2000) 38873890.

[19] W. Krawiec, L.G. Scanlon, J.P. Fellner, R.A. Vaia, S. Vasudevan, E.P. Giannelis; J. Power Sources, 54(2) (1995) 310-315.

[20] J.M. Brown, D. Curliss, R.A. Vaia; Chem. Mater., 12(11) (2000) 3376-3384.

[21] S.J. Mills, A.G. Christy, J.-M. R. Génin, T. Kameda, F. Colombo; Mineralogical Magazine, 76(05) (2012) 1289-1336.

[22] G. Mishraa, B. Dasha, S. Pandey, Applied Clay Science, 153 (2018) 172-186.

[23] S.B. Ötvös, Á. Georgiádes, M. Ádok-Sipiczki, R. Mészáros, I. Pálinkó, P. Sipos, F. Fülöp; Applied Catalysis A: General, 501 (2015) 63-73.

[24] H.M. Shi, J. He; J. Catal., 279 (2011) 155-162.

[25] C. Chen, P. Gunawan, R. Xu; J. Mater. Chem., 21 (2011) 1218-1225

[26] J.H. Choy, J.M. Oh, M. Park, K.M. Sohn, J.W. Kim; Adv. Mater., 16 (2004) 1181-1184. 
[27] Y. Wang, D. Zhang, Q. Bao, J. Wu, Y. Wan; J. Mater. Chem., 22 (2012) 23106-23113.

[28] L. Mohapatra, K.M. Parida; J. Mater. Chem. A, 4 (2016) 10744-10766.

[29] T. Aradi, V. Hornok, I. Dékány; Colloids and Surfaces A: Physicochemical and Engineering Aspects, 319(1-3) (2008) 116-121.

[30] V. Tóth, M. Sipiczki, A. Pallagi, Á. Kukovecz, Z. Kónya, P. Sipos, I. Pálinkó; Chemical Papers, 68(5) (2014) 633-637.

[31] M. Sipiczki, D. Srankó, Á. Kukovecz, Z. Kónya, P. Sipos, I. Pálinkó; Chemical Papers, 65(6) (2011) 840-846.

[32] Z. Timár, G. Varga, S. Muráth, Z. Kónya, Á. Kukovecz, V. Havasi, A. Oszkó, I. Pálinkó, P. Sipos; Catalysis Today, 284 (2017) 195-201.

[33] U. Costantino, F. Marmottini, M. Nocchetti, R. Vivani; Eur. J. Inorg. Chem. 10 (1998) 1439-1446.

[34] K.L. Erickson, T.E. Bostrom, R.L. Frost; Mater. Lett., 59 (2005) 226-229.

[35] E. Géraud, V. Prévot, F. Leroux; Journal of Physics and Chemistry of Solids, 67 (2006) 903-908.

[36] S. Xu, Y. Yang, T. Xu, Y. Kuan, M. Dong, F. Zhang, F. Besenbacher, D. G. Evans; Chemical Engineering Science, 66 (2011) 2157-2163.

[37] Y.-M. Zheng, N. Li, W-D. Zhang; Colloids and Surfaces A: Physicochem. Eng. Aspects, 415 (2012) 195- 201.

[38] J. Wang, D. Li, X. Yu, M. Zhang, X. Jing; Colloid. Polym. Sci., 288 (2010) 1411-1418.

[39] A. Naghash, T.H. Etsell, B.J. Lu; Mater. Chem., 18 (2008) 2562-2568.

[40] M.B. Kievani, M. Edraki; Front. Chem. Sci. Eng., 9(1) (2015) 40-45.

[41] I. Palinko, I. Kiricsi, I. Hannus; Reaction Kinetics and Catalysis Letters, 64 (1998) 317-232.

[42] I. Palinko, K. Lazar, I. Hannus, I. Kiricsi; J. Physics and Chemistry of Solids, 57 (1996) 1067-1072.

[43] B.C. Rankine, W.W. Emerson; Journal of the Science of Food and Agriculture, 14 (1963) 685-689.

[44] C. Aguzzi, P. Cerezo, C. Viseras, C. Caramella; Applied Clay Science, 36 (2007) 22-36.

[45] G.V. Joshi, H. A. Patel, B.D. Kevadiya, H.C. Baja; Applied Clay Science, 45 (2009) 248-253.

[46] J. Ménesi, R. Kékesi, A. Oszkó, V. Zöllmer, T. Seemann, A. Richardt, I. Dékány; Catalysis Today, 144 (2009) 160-165.

[47] J. Ménesi, R. Kékesi, L. Körösi, V. Zöllmer, A. Richardt, I. Dékány; International Journal of Photoenergy, 2008 (2008) 1-9.

[48] K. Sato; J. Ceram. Soc. Japan, 115 (2007) 124-30.

[49] D.L. Batchelar, M.T.M Davidson, W. Dabrowski, I.A. Cunningham; Med. Phys., 33 (2006) 90415.

[50] P. Malmberg, H. Nygren; Proteomics, 8 (2008) 3755-62.

[51] M. Sadat-Shojai, M.-T. Khorasani, E. Dinpanah-Khoshdargi, A.JamshidiActa Biomaterialia 9 (2013) 7591-7621.

[52] A. Rabiei, T. Blalock, B. Thomas, J. Cuomo, Y. Yang, J. Ong; Mater. Sci. Eng. C, 27 (2007) 52933.

[53] L. Chen, J.M. Mccrate, J.C.M. Lee, H. Li; Nanotechnology, 22 (2011) 105708.

[54] I.M. Pelin, S.S. Maier, G.C. Chitanu, V. Bulacovschi; Mater. Sci. Eng. C, 29 (2009) 2188-94.

[55] P. O’Hare, B.J. Meenan, G.A. Burke, G. Byrne, D. Dowling, J.A. Hunt; Biomaterials, 31 (2010) 515-22.

[56] E. Marini, P. Ballanti, G. Silvestrini, F. Valdinucci, E. Bonucci, J Orthopaed Traumatol 5 (2004) $34-43$. 
[57] S.K. Sethi, G. Manik; Polymer-Plastics Technology and Angineering, 57 (2018).

[58] T. Adachi, S.S. Latthe, S.W. Gosavi, N. Roy, N. Suzuki, H. Ikari, K. Kato, K. Katsumata, K. Nakata, M. Furudate, T. Inoue, T. Kondo, M. Yuasa, A. Fujishima, C. Terashima; Applied Surface Science, 458 (2018) 917-923.

[59] J.T. Woodward, H. Gwin, D.K. Schwartz; Langmuir, 16(6) (2000) 2957-2961.

[60] T. Nishino, M. Meguro, K. Nakamae, M. Matsushita, Y. Ueda; Langmuir, 15 (1999) 4321-4323.

[61] R.N. Wenzel; Ind. Eng. Chem., 28(8) (1936) 988-994.

[62] R.N. Wenzel; J. Phys. Chem., 53(9) (1949) 1466-1467.

[63] H. Ogihara, J. Xie, T. Saji; Colloids Surf. A, 434 (2013) 35-41.

[64] P.P. Goodwyn, Y. Maezono, N. Hosoda, K. Fujisaki; Naturwissenschaften, 96(7) (2009) 781-787.

[65] H. Zhu, Z. Guo, W. Liu; Chem. Commun., 50 (2014) 3900.

[66] M.L. Ma, R.M. Hill; Curr. Opin. Colloid Interface Sci., 11(4) (2006) 193-202.

[67] P. Roach, N.J. Shirtcliffe, M.I. Newton; Soft Matter, 4(2) (2008) 224-240.

[68] A. Roig, E. Molins, E. Rodríguez, S. Martínez, M. Moreno-Mañas, A. Vallribera; Chem. Commun., 20 (2004) 2316-2317.

[69] T.T. Isimjan, T.Y. Wang, S. Rohani; Chem. Eng. J., 210 (2012) 182-187.

[70] C. Dong, Y. Gu, M. Zhong, L. Li, K. Sezer. M. Ma, W. Liu; J. Mater. Process. Technol., 211 (7) (2011) 1234-1240.

[71] A. Pozzato, S. Dal Zilio, G. Fois, D. Vendramin, G. Mistura, M. Belotti, Y. Chen, M. Natali; Microelectronic Engineering, 83 (2006) 884-888.

[72] J. Ou, M. Liu, W. Li, F. Wang, M. Xue, C. Li; Appl. Surf. Sci., 258(10) (2012) 4724-4728.

[73] Y. Huang, D.K. Sarkar, D. Gallant, X.G. Chen; Appl. Surf. Sci., 282 (2013) 689-694.

[74] J. Drelich, E. Chibowski, D.D. Meng, K. Terpilowski; Soft Matter, 7(21) (2011) 9804.

[75] L.A.M. Carrascosa, D.S. Facio, M.J. Mosquera; Nanotechnology, 27(9) (2016).

[76] M.S. Khalil-Abad, M.E. Yazdanshenas; Journal of Colloid and Interface Science, 351 (2010) 293298.

[77] H.J. Gwon, Y. Park, C.W. Moon, S. Nahm, S.-J. Yoon, S.Y. Kim, H.W. Jang; Nano Res., 7 (2014) 670.

[78] O.U. Nimittrakoolchai, S. Supothina; J. Eur. Ceram. Soc., 28(5) (2008) 947-952.

[79] T. Liu, S. Chen, S. Cheng, J. Tian, X. Chang, Y. Yin; Electrochim. Acta, 52(28) (2007) 8003-8007.

[80] S. Rajeshkumar, C. Malarkodi; Bioinorganic Chemistry and Applications, 2014, 1-10.

[81] R. Mohandas, A.A. Ejaz; Nature Reviews Nephrology, 10 (2014) 302-304.

[82] A. Fujishima, K. Honda; Nature, 238 (1972) 37-8.

[83] A.B. Djurišić, X. Chen, Y.H. Leung, A. Man Ching Ng; Journal of Materials Chemistry, 22(14) (2012) 6526-6535.

[84] X. Zhang, H. Kono, Z. Liu, S. Nishimoto, D.A. Tryk, T. Murakami, H. Sakai, M. Abe, A. Fujishima; Chem. Commun., 46 (2007) 4949.

[85] G. Martra, S. Coluccia, L. Marchese, V. Augugliaro, V. Loddo, L. Palmisano, M. Schiavello; Catal. Today, 53 (1999) 695-702.

[86] P. Calza, E. Pelizzetti, K. Mogyorósi, R. Kun, I. Dékány; Appl. Catal. B: Environ., 72 (2007) 314321.

[87] V. Maurino, M. Minella, F. Sordello, C. Minero; Appl. Catal. A: Gen., 521 (2015) 57-67. 
[88] Á. Veres, T. Rica, L. Janovák, M. Dömök, N. Buzás, V. Zollmer, T. Seemann, A. Richardt, I. Dékány; Catal. Today, 181 (2012) 156- 162.

[89] Sz.P. Tallósy, L. Janovák, J. Ménesi, E. Nagy, Á. Juhász, L. Balázs, I. Deme, N. Buzás, I. Dékány; Environ. Sci. Pollut. Res., 21 (2014) 11155-11167.

[90] R. Barabás, M. Czikó, I. Dékány, L. Bizo, E.S. Bogya; Chemical Papers, 67(11) (2013) 1414-1423.

[91] K. Böckenhoff, W.R. Fischer; Fresenius J. Anal. Chem., 371 (2001) 670-674.

[92] R. López, R. Gómez; J. Sol-Gel Sci. Technol., 61 (2012) 1-7.

[93] G.F. Samu, Á. Veres, S.P. Tallósy, L. Janovák, I. Dékány, A. Yepez, R. Luque, Cs. Janáky; Catalysis Today, 284 (2017) 3-10.

[94] K. Stepien; Key Engineering Materials, 637 (2015) 69-73.

[95] E.S. Gadelmawla, M.M. Koura, T.M.A. Maksoud, I.M. Elewa, H.H. Soliman; Journal of Materials Processing Technology, 123 (2002) 113-145.

[96] A. Marmur, C.D. Volpe, S. Siboni, A. Amirfazli, J.W. Drelich; Surface Innovations, 5(1) (2017) 3.

[97] J. Drelich; Surface Innovations, 1(4) (2013) 248-254.

[98] E. Chibowski; Advances in Colloid and Interface Science, 103 (2003) 149-172.

[99] Y. Nosaka, A.Y. Nosaka; Chem. Rev., 117 (2017) 11302-11336.

[100] K. Bohinc, G. Dražič, R. Fink, M. Oder, M. Jevšnik, D. Nipič, K. Godič Torkar, P. Raspor; Int. J. Adhes. Adhes., 50 (2014) 265-272.

[101] D. Guérin, J.-C. Vuillemard, M. Subirade; Journal of Food Protection, 66(11) (2003) 2076-2084.

[102] A.S. Cunha, J.L. Grossiord, F. Puisieux, M. Seiller; J. Microencapsul., 14 (1997) 311-319.

[103] S. Baliga, S. Muglikar, R. Kale; J. Indian Soc. Periodontol., 17(4) (2013) 461-465.

[104] M. Pietrzyńska, A. Voelkel; Microchemical Journal, 134 (2017) 197-201.

[105] L. Deng, Z. Shi, X. Peng; RSC Adv., 5 (2015) 49791-49801.

[106] S. Aisawa, Y. Ohnuma, K. Hirose, S. Takahashi, H. Hirahara, E. Narita; Applied Clay Science 28 (2015) 137- 145.

[107] Z. Dinya; Infravörös spektroszkópia. Kézirat, Tankönyvkiadó, Budapest, 1981.

[108] W. Geng, T. Nakajima, H. Takanashi, A. Ohki; Fuel, 88 (2009) 139-144.

[109] M. Ibrahim, A. Nada, D.E. Kamal; Indian Journal of Pure \& Applied Physics., 43 (2005) 911-917.

[110] L.P.F. Benício, R.A. Silva, J.A. Lopes, D. Eulálio, R.M. Menezes dos Santos, L. Angelo de Aquino, L. Vergütz, R.F. Novais, L. Marciano da Costa, F.G. Pinto, J. Tronto; R. Bras. Ci. Solo., 39 (2015) 1-13.

[111] M. Marosi, D. Nagy, T. Farkas, Z. Kis, É. Rózsa, H. Robotka, F. Fülöp, L. Vécsei, J. Toldi; J. Neural Transm., 117 (2010) 183-188.

[112] G.B. Glavin, C. Pinsky; Res. Commun. Chem. Pathol. Pharmacol., 64(1) (1989) 111-119.

[113] G.B. Glavin, R. Bose, C. Pinsky; Prog. Neuro Psychophormocol., 13 (1989) 569-572.

[114] M.L. Parello, R. Rojas, C.E. Giacomelli; J. of Coll. and Inter. Sci., 351 (2010) 134-139.

[115] N. Varga, E. Csapó, Z. Majláth, I. Ilisz, I.A. Krizbai, I. Wilhelm, L.J. Knappe, J. Toldi, L. Vécsei, I. Dékány; European Journal of Pharmaceutical Sciences, 86 (2016) 67-74.

[116] Á. Juhász, M. Luty-Błocho, M. Wojnicki, G.K. Tóth, E. Csapó; Microchemical Journal, 147 (2019) 311-318.

[117] E. Csapó, H. Szokolai, Á. Juhász, N. Varga, L. Janovák, I. Dékány; Carbohydrate Polymers, 195 (2018) 99-106.

[118] P. Costa, J.M.S. Lobo; European Journal of Pharmaceutical Sciences, 13 (2001) 123-133. 
[119] I.Y. Wu, S. Bala, N. Škalko-Basnet, M. Pio di Cagno; European Journal of Pharmaceutical Sciences, 138 (2019) 105026.

[120] A.F.R. Pimenta, A.P. Serro, R. Colaço, A. Chauhan; European Journal of Pharmaceutics and Biopharmaceutics, 141 (2019) 51-57.

[121] Z. Wu, H. Joo, T.G. Lee, K. Lee; J. Control. Rel., 104 (2005) 497-505.

[122] S. Dash, P.N. Murthy, L. Nath, P. Chowdhury; Acta Poloniae Pharmaceutica and Drug Research, 67 (2010) 217-223.

[123] F.P. de Sá, B.N. Cunha, L.M. Nunes; Chemical Engineering Journal, 215-216 (2013) 122-127.

[124] Z. Navrátilová, R. Maršálek; Clay Minerals in Nature - Their Characterization, Modification and Application, Chapter 14, 326. DOI: 10.5772/2708

[125] P. Singha, K. Kumari, A. Katyal, R. Kalra, R. Chandra; Spectrochimica Acta Part A, 73 (2009) 218-220.

[126] S.M. Magana, P. Quintana, D.H. Aguilar, J.A. Toledo, C. Ángeles-Chávez, M.A. Cortés, L. León, Y. Freile-Pelegrín, T. López, R.M. Torres Sánchez; Journal of Molecular Catalysis A: Chemical, 281 (2008) 192-199.

[127] L. Janovák, S.P. Tallósy, M. Sztakó, Á. Deák, T. Bitó, N. Buzás, Gy. Bártfai, I. Dékány; J. Drug Del. Sci. Tech., 24 (2014) 628-636.

[128] G.S. Thomas, A.V. Radha, P.V. Kamath; J. Phys. Chem. B, 110 (2006) 12365-12371.

[129] L. Zhang, J. Liu, H. Xiao, D. Liu, Y. Qin, H. Wu, H. Li, N. Du, W. Hou; Chem. Eng. J., 250 (2014) 1-5.

[130] T. Szabó, J. Németh, I. Dékány; Colloids Surf. A: Physicochem. Eng. Aspects, 230 (2004) 23-35.

[131] A. Janotti, C.G. Van de Walle; Rep. Prog. Phys., 72 (2009) 126501.

[132] M. Miwa, A. Nakajima, A. Fujishima, K. Hashimoto, T. Watanabe; Langmuir, 16 (2000) 57545760.

[133] G. McHale, N.J. Shirtcliffe, M.I. Newton; Langmuir, 20 (2004) 10146-10149.

[134] H. Tavana, F. Simon, K. Grundke, D.Y. Kwok, M.L. Hair, A.W. Neumann; J. Colloid Interface Sci., 291 (2005) 497-506.

[135] G. Fu, P.S. Vary, C.T. Lin; J. Phys. Chem. B, 109(18) (2005) 8889-8898.

[136] K. Gupta, R.P. Singh, As. Pandey, A. Pandey; Beilstein J. Nanotechnol., 4 (2013) 345-351.

[137] N. Nataraj, G.S. Anjusree, A.A. Madhavan, P. Priyanka, D. Sankar, N. Nisha, S.V. Lakshmi, R. Jayakumar, A. Balakrishnan, R. Biswas; J. Biomed. Nanotechnol., 10(5) (2014) 864-870.

[138] T. Sawada, F. Yoshino, K. Kimoto, Y. Takahashi, T. Shibata, N. Hamada, T. Sawada, M. Toyoda; J. Dent. Res., 89(8) (2010) 848-853.

[139] J.F. Perez-Benito; J Phys. Chem. A 108 (2004) 4853-4858.

[140] Á. Veres, J. Ménesi, Á. Juhász, O. Berkesi, N. Ábrahám, G. Bohus, A. Oszkó, G. Pótári, N. Buzás, L. Janovák, I. Dékány; Coll. Polym. Sci. 292 (2014) 207-217.

[141] S. Bayoudh, A. Othmane, L. Ponsonnet, H.B. Ouada; Colloids Surf. A: Physichochem Eng. Aspects, 318 (2008) 291-300.

[142] B. Li, B.E. Logan; Colloids and Surfaces B: Biointerfaces, 36 (2004) 81-90.

[143] R.L. Taylor, J. Verran, G.C. Lees, A.J.P Ward; Journal Of Materials Science: Materials In Medicine, 9 (1998) 17-22.

[144] C. Diaz, P.L. Schilardi, R.C. Salvarezza, M. Fernández Lorenzo de Mele; Langmuir, 23 (2007) 11206-11210.

[145] X. Zhang, L. Wang, E. Levänen; RSC Advances, 3 (2013) 12003-12020. 
[146] M. Katsikogianni, Y.F. Missirlis; European Cell and Materials, 8 (2004) 37-57.

[147] G.A. O’Toole, L.A. Pratt, P.I. Watnick, D.K. Newman, V.B. Weaver, R. Kolter; Methods in Enzymology, 310 (1999) 91-109.

[148] K. Bohinc, G. Dražič, A. Abram, M. Jevšnik, B. Jeršek, D. Nipič, M. Kurinčič, P. Raspor; Int. J. Adhes. Adhes., 68 (2016) 39-46.

[149] G. Wistreich, J.W. Bartholomew; J. gen. Microbiol., 59 (1969) 223-227.

[150] O.Y.A. Costa, J.M. Raaijmakers, E.E. Kuramae; Front Microbiol., 9 (2018) 1636.

[151] Á. Veres, L. Janovák, T. Bujdosó, T. Rica, E. Fodor, Sz. Tallósy, N. Buzás, E. Nagy, I. Dékány; J. Adv. Oxid. Technol., 15 (2012) 205-216.

[152] ISO 27447:2009; Fine ceramics (advanced ceramics, advanced technical ceramics) - Test method for antibacterial activity of semiconducting photocatalytic materials (2009)

[153] M.N. Khan, J. Bashir; J. Mod. Phys., 2 (2011) 962-965.

[154] B.Ohtani, O.O. Prieto-Mahaney, D.Li, R. Abe; Journal of Photochemistry and Photobiology A: Chemistry, 216 (2010) 179-182. 


\section{Melléklet}
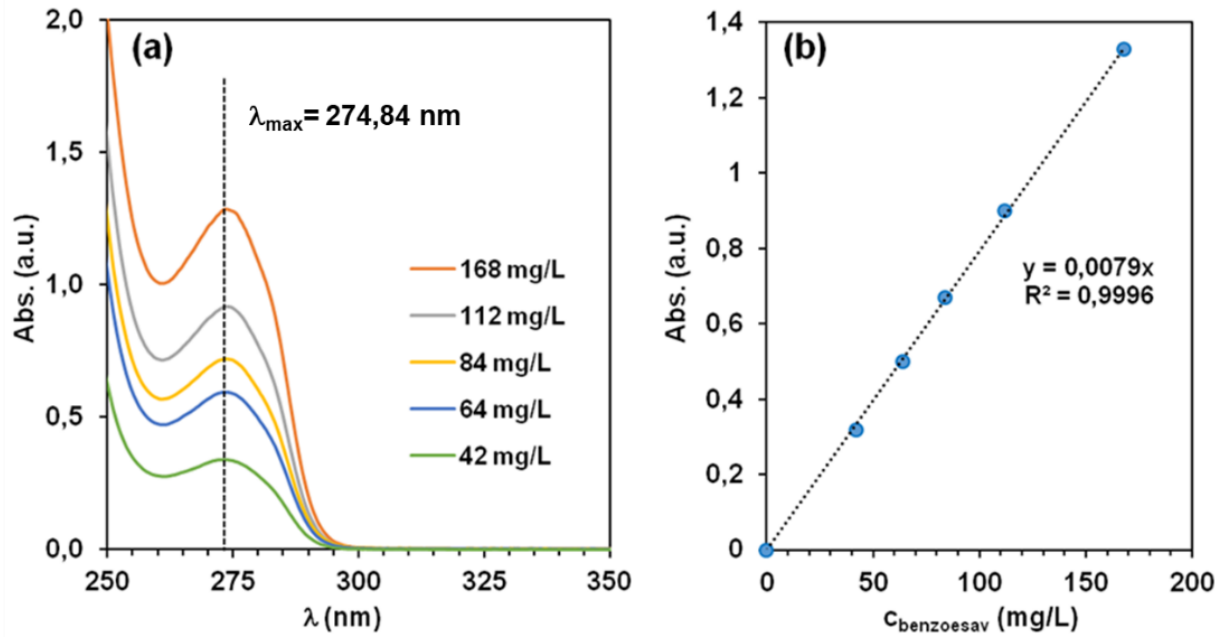

1. M ábra. A különböző koncentrációjú benzoesav-oldatok abszorbancia spektrumai (a), ill. az azokból meghatározott kalibrációs egyenes (b).

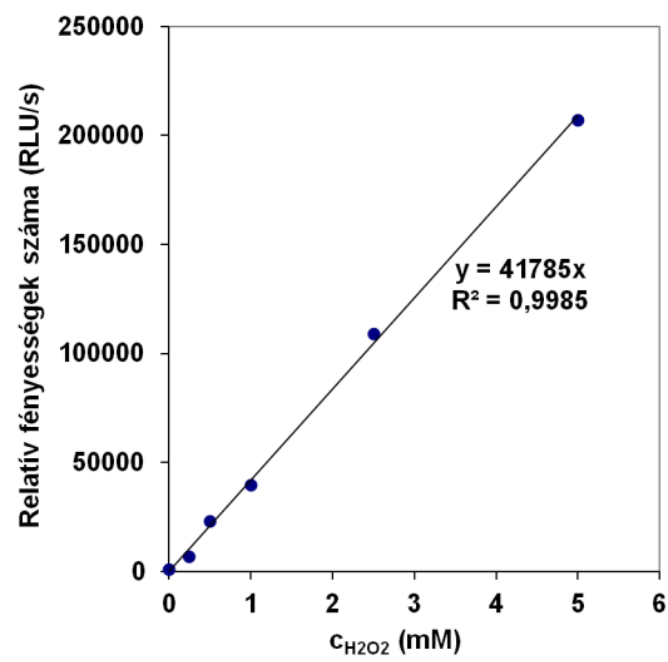

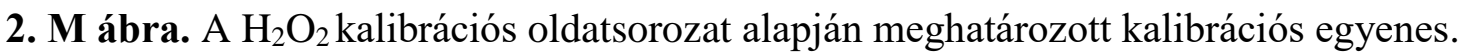



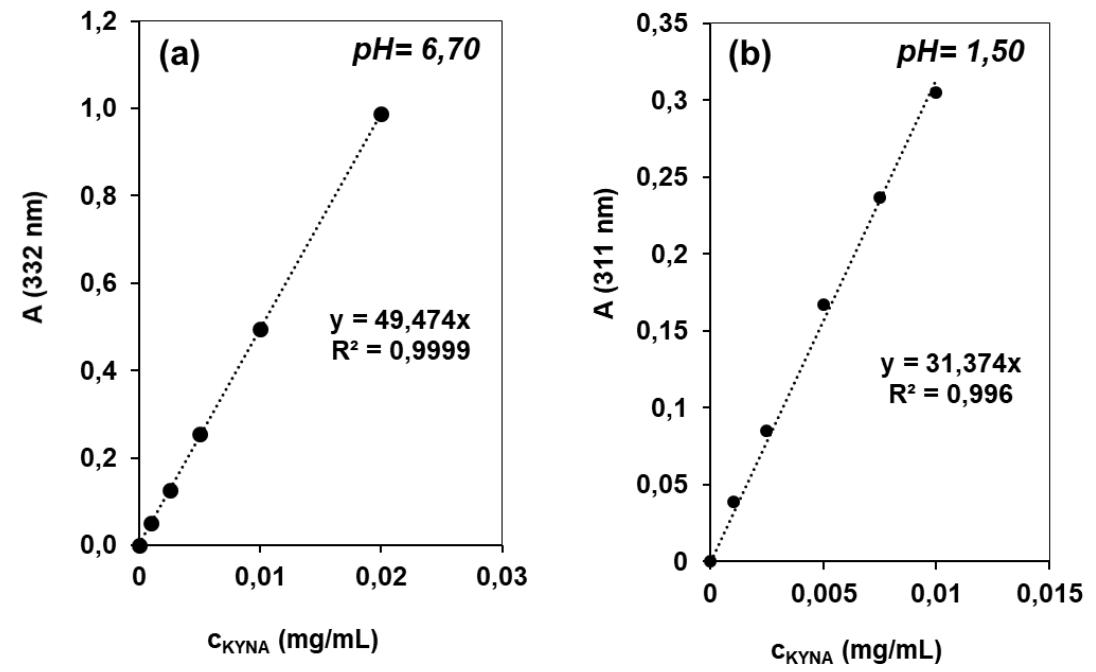

3. M ábra. A kinurénsav-oldat kalibrációs sorozatának abszorbancia spektrumaiból meghatározott kalibrációs egyenes $\mathrm{pH}=6,70$ (a) és 1,5 (b) értéken.
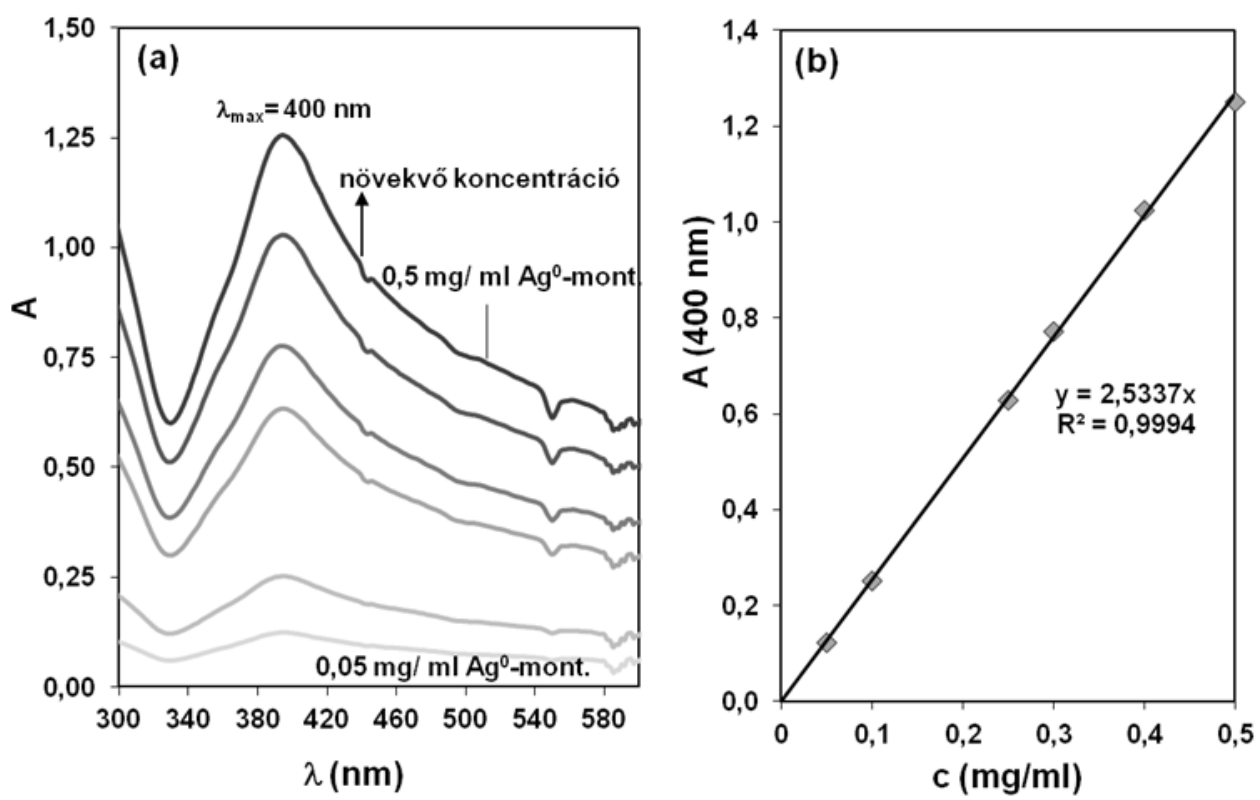

4. M ábra. A különböző töménységü $\mathrm{Ag}^{0}$-montmorillonit szuszpenziók abszorbancia spektrumai (a) és az azok alapján meghatározott kalibrációs egyenes (b). 

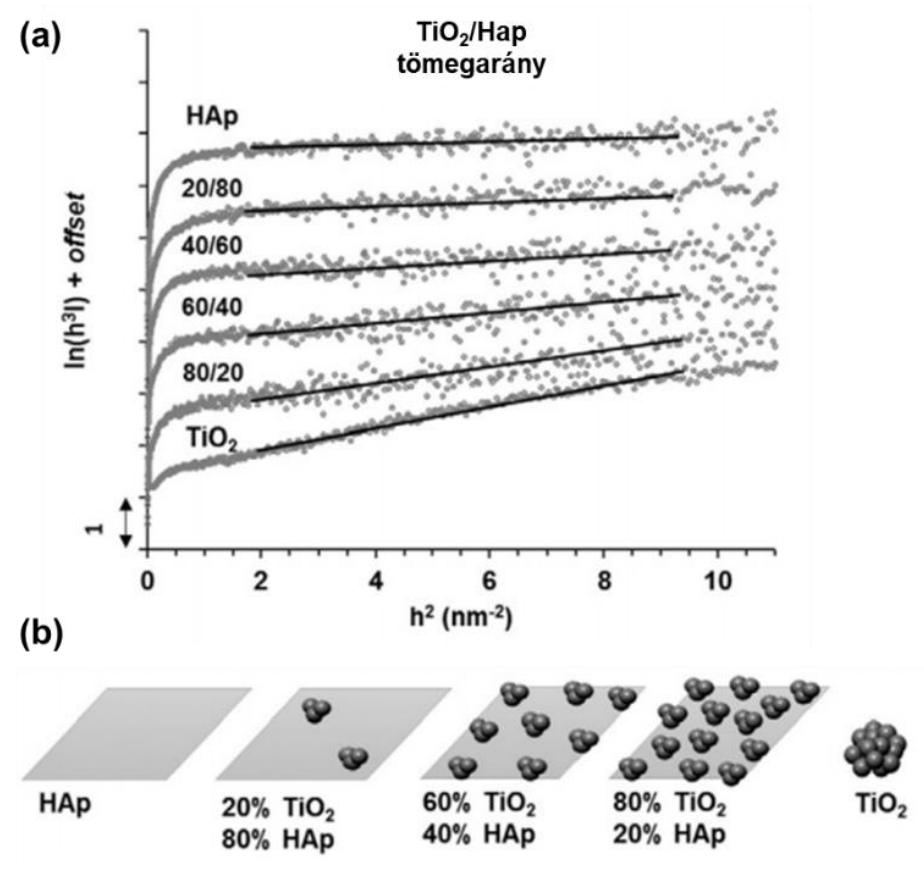

5. M ábra. $\mathrm{A} \mathrm{TiO}_{2}$ jelenlétében előállított $\mathrm{HAp}$ minták (csapadékképzéssel előállított $\mathrm{TiO}_{2} / \mathrm{HAp}$ ) szórásgörbéinek Porod féle reprezentációja $\left(\ln \left(h^{3} I\right)\right.$ ábrázolása a $h^{2}$ függvényében) (a) és a minták sematikus ábrázolása (b).

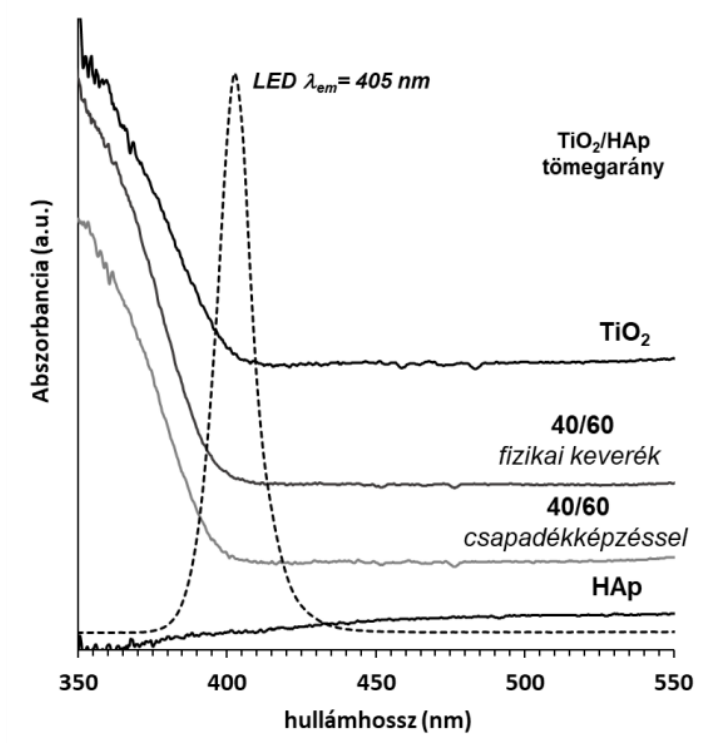

6. M ábra. A kiindulási $\mathrm{TiO}_{2}$ és $\mathrm{HAp}$, valamint $40 / 60 \mathrm{~m} / \mathrm{m} \%$-os összetételü (fizikai keverék és csapadékképzéssel előállított) $\mathrm{TiO}_{2} / \mathrm{HAp}$ minták diffúz-reflexiós spektrumai. Szaggatott vonallal a $\lambda_{\max }=405 \mathrm{~nm}$-es LED fényforrás emissziós spektruma. 


\section{Köszönetnyilvánítás}

Ezúton szeretném megköszönni témavezetőmnek, Dr. Janovák Lászlónak, hogy a csoportban töltött éveim és doktori munkám során mindvégig hasznos elméleti és gyakorlati tanácsokkal látott el. Szeretném megköszönni Prof. Dr. Dékány Imre akadémikusnak, hogy lehetővé tette számomra, hogy kutatócsoportjában végezhettem doktori munkámat és szakmai fejlődésemet mindvégig támogatta. Szeretném megköszönni szakmai vezetőimnek, hogy lehetőséget biztosítottak külföldi tanulmányútjaimhoz, támogatták konferencia részvételeimet és szakmai szerepvállalásaimat.

Szeretném megköszönni Prof. Dr. Klemen Bohincnak, hogy egy együttmüködés keretein belül (COST, STSM CM1101), lehetőséget biztosított számomra a Ljubjlanai Egyetem Egészségügyi Karán mikrobiológiai vizsgálatokat végezhessek. Köszönettel tartozom Prof. Dr. Karmen GodičTorkarnak mikrobiológus professzor asszonynak, aki nyomon követte és segítette mikrobiológiai kutatómunkámat és szakmai tanácsokkal látott el. Továbbá köszönettel tartozom Dr. Anže Abram kutatónak (“Jožef Stefan” Intézetből, Ljubljana, Szlovénia) a pásztázó elektronmikroszkópos felvételek kivitelezésében nyújtott segítségért a hibrid rétegek felszínén megtapadt baktérium sejtek vizsgálata során.

Köszönettel tartozom Hörits Zsuzsannának a fajlagos (BET) felület és a röntgen-diffrakciós (XRD) mérésekben adott segítségéért, Dr. Sebök Dánielnek a kisszögü röntgenszórási (SAXS) vizsgálatok kivitelezésében nyújtott segítségéért.

Szeretném megköszönni a Fizikai Kémiai és Anyagtudományi Tanszék munkatársainak, hogy kutatómunkám során a felmerült elméleti, illetve gyakorlati problémák megoldásában segítségemre voltak. Külön köszönöm Juhászné Dr. Csapó Editnek és Dr. Varga Viktóriának a szakmai és baráti tanácsokat.

Hálás szívvel köszönöm szüleimnek, testvéremnek és családjának, hogy mindvégig mellettem álltak, szeretetük és támogatásuk végig kísérte az egyetemi és kutató éveimet. Külön köszönettel tartozom férjemnek, aki szeretetével, kitartó türelmével nyugodt körülményeket biztosított a munkám végzéséhez.

Szeretném megköszönni a GINOP-2.3.2-15-2016-00013 azonosító számmal rendelkező „Funkcionális felületeken alapuló intelligens anyagok - az elöállitástól az alkalmazásokig” címü pályázati projekt által nyújtott anyagi támogatást, mely lehetővé tette a munka elvégzését.

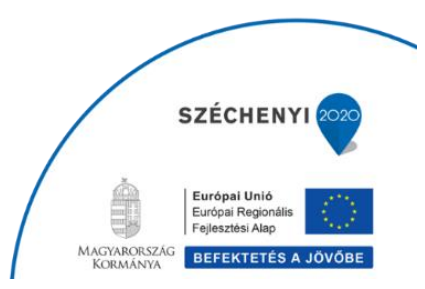




\section{Publikációs gyüjtemény}

Magyar Tudományos Mủvek Tára (MTMT) azonosító: 10055142

ORCID azonosító: 0000-0002-6781-1727

\section{Az értekezés témájához közvetlen kapcsolódó tudományos publikációk:}

1. Ágota Deák, L. Janovák, SP. Tallósy, T. Bitó, D. Sebők, N. Buzás, I. Pálinkó, I. Dékány. Spherical $\mathrm{LDH}-\mathrm{Ag}^{0}$-montmorillonite heterocoagulated system with $\mathrm{pH}$-dependent sol-gel structure for controlled accessibility of AgNPs immobilised on the clay lamellae.

Langmuir 31:(6) (2015) 2019-2027.

$\left(\mathrm{IF}_{2015}=3,993 ; \mathrm{FHSZ}=8\right)$

2. Ágota Deák, L. Janovák, E. Csapó, D. Ungor, I. Pálinkó, S. Puskás, T. Ördög, T. Ricza, I. Dékány. Layered double oxide (LDO) particle containing photoreactive hybrid layers with tunable superhydrophobic and photocatalytic properties.

Applied Surface Science 389 (2016) 294-302.

$\left(\mathrm{IF}_{2016}=3,387 ; \mathrm{FHSZ}=9\right)$

3. L. Janovák, Ágota Deák, Sz. P. Tallósy, D. Sebők, E. Csapó, K. Bohinc, A. Abram, I. Palinko, I. Dékány. Hydroxyapatite-enhanced structural, photocatalytic and antibacterial properties of photoreactive $\mathrm{TiO}_{2} / \mathrm{HAp} /$ polyacrylate hybrid thin films.

Surface and Coatings Technology, 326 (2017) 316-326.

$\left(\mathrm{IF}_{2017}=2,906 ; \mathrm{FHSZ}=7\right)$

4. Ágota Deák, E. Csapó, Á. Juhász, I. Dékány, L. Janovák.

Anti-ulcerant kynurenic acid molecules intercalated Mg/Al-layered double hydroxide and its release study

Applied Clay Science 156 (2018) 28-35.

$\left(\mathrm{IF}_{2017}=3,641 ; \mathrm{FHSZ}=0\right.$; függő $\left.\mathrm{HSZ}=1\right)$

5. Ágota Deák, L. Janovák, Sz. P. Tallósy, K. Godič-Torkar, A. Abram, I. Dékány, K. Bohinc.

Controlled adhesion and inactivation of nosocomial bacteria on photoreactive composite coating with designed wetting properties.

International Journal of Antimicrobial Agents (2019) folyóirathoz benyújtott.

Összesített impakt faktora $(\Sigma$ IF $)=\mathbf{1 3 , 9 2 7}$

Független hivatkozások száma $($ FHSZ $)=\mathbf{2 4}$ 


\section{Egyéb tudományos közlemények:}

1. L. Janovák, Sz. P. Tallósy, M. Sztakó, Á. Deák, T. Bitó, N. Buzás, Gy. Bártfai, I. Dékány. Synthesis of pH-sensitive copolymer thin solid films embedded with silver nanoparticles for controlled release and their fungicide properties. Journal of Drug Delivery Science and Technology 24:(6) (2014) 628-636. $\left(\mathrm{IF}_{2014}=0,476 ; \mathrm{FHSZ}=2\right.$; függö $\left.\mathrm{HSZ}=4\right)$

2. Sz. P. Tallósy, L. Janovák, E. Nagy, Á. Deák, Á. Juhász, E. Csapó, N. Buzás, I. Dékány. Adhesion and inactivation of Gram-negative and Gram-positive bacteria on photoreactive $\mathrm{TiO}_{2} /$ polymer and $\mathrm{Ag}-\mathrm{TiO} /$ polymer nanohybrid films. Applied Surface Science 371 (2016) 139-150. $\left(\mathrm{IF}_{2016}=3,387\right.$; $\mathrm{FHSZ}=18$; függő $\mathrm{HSZ}=2$ )

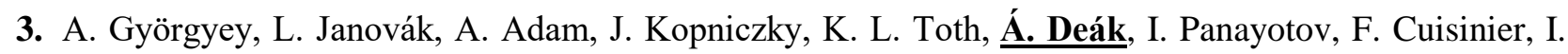
Dékány, K. Turzó. Investigation of the in vitro photocatalytic antibacterial activity of nanocrystalline $\mathrm{TiO}_{2}$ and coupled $\mathrm{TiO}_{2} / \mathrm{Ag}$ containing copolymer on the surface of medical grade titanium. Journal of Biomaterials Applications 31:(1) (2016) 55-67. $\left(\mathrm{IF}_{2016}=2,310\right.$; $\mathrm{FHSZ}=8$; függő $\left.\mathrm{HSZ}=4\right)$

4. R. Masa, Á. Deák, G. Braunitzer, Zs. Tóth, J. Kopniczky, I. Pelsőczi-Kovács, K. Ungvári, I. Dékány, K. Turzó. $\mathrm{TiO}_{2} / \mathrm{Ag}-\mathrm{TiO}_{2}$ nanohybrid films are cytocompatible with primary epithelial cells of human origin: an in vitro study. Journal of Nanoscience and Nanotechnology 18 (6) (2018) 3916-3924(9). (IF ${ }_{2016}=$ 1,$483 ;$ FHSZ $=0$ )

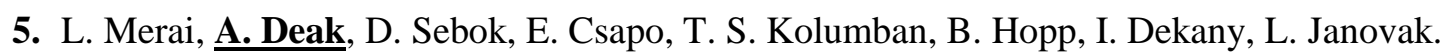
Photoreactive composite coating with composition dependent wetting properties.

Express Polymer Letters 12 (2018) 1061-1071. $\left(\mathrm{IF}_{2018}=2,875\right.$; FHSZ=0)

6. L. Janovák, Á. Dernovics, L. Mérai, Á. Deák, D. Sebők, E. Csapó, A. Varga, I. Dékány, Cs. Janáky. Microstructuration of poly(3-hexylthiophene) leads to bifunctional superhydrophobic and photoreactive surfaces. Chemical Communications 54(6) (2018) 650-653. $\left(\mathrm{IF}_{2018}=6,164 ; \mathrm{FHSZ}=1\right.$; függő $\left.\mathrm{HSZ}=1\right)$

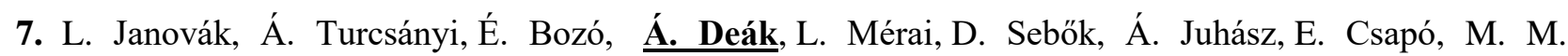
Abdelghafour, Farkas E. Preparation of novel tissue acidosis-responsive chitosan drug nanoparticles: Characterization and in vitro release properties of $\mathrm{Ca}^{2+}$ channel blocker nimodipine drug molecules. European Journal of Pharmaceutical Sciences 123 (2018) 79-88. $\left(\mathrm{IF}_{2018}=3,532\right.$; FHSZ=0)

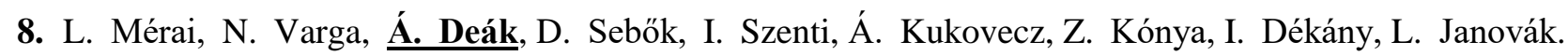
Preparation of photocatalytic thin films with composition dependent wetting properties and self-healing ability. Catalysis Today 328 (2019) $85-90 .\left(\mathrm{IF}_{2018}=4,888 ; \mathrm{FHSZ}=0\right)$ 


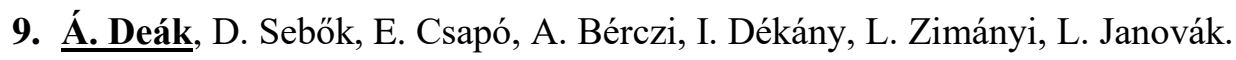
Evaluation of $\mathrm{pH}$ - responsive poly(styrene-co-maleic acid) copolymer nanoparticles for the encapsulation and $\mathrm{pH}$-dependent release of ketoprofen and tocopherol model drugs. European Polymer Journal 114 (2019) $361-368 .\left(\mathrm{IF}_{2018}=3,621 ; \mathrm{FHSZ}=0\right)$

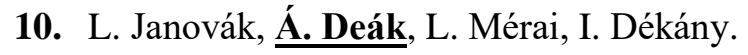

Vizlepergetö és fény hatására öntisztuló bifunkciós vékonyrétegek.

Magyar Kémikusok Lapja 74(2) (2019) 48-52.

11. L. Janovák, Á. Deák, L. Mérai, Sz. P. Tallósy, I. Dékány.

Öntisztuló felületek alkalmazása szerves anyagok eliminálására, ill. biológiai rendszerek ártalmatlanitására.

Magyar Kémiai Folyóirat - Kémiai Közlemények 125 (2019) 83-90.

Egyéb témában megjelent publikációk összesített impakt faktora $(\Sigma \mathrm{IF})=\mathbf{2 8 , 7 3 6}$

Független hivatkozások száma $($ FHSZ) $=\mathbf{2 9}$

Függő hivatkozások száma (függő HSZ) = 5

Összesített publikációk összesített impakt faktora $(\Sigma \Sigma$ IF $)=42,663$

Összesített Független hivatkozások száma $=53$

Összesített Függő hivatkozások száma $=6$ 